TAXAS DE MINERALIZAÇÃO E DE LIXIVIAÇÃO DO NITROGÊNIO, E ALTERAÇÕES DA FERTILIDADE DE UM LATOSSOLO VERMELHOAMARELO DEGRADADO E OUTRO NÃO-DEGRADADO FERTILIZADOS COM BIOSSÓLIDO E FLORESTADOS COM Eucalyptus grandis

\author{
MÁRCIA TOFFANI SIMÃO SOARES
}

Tese apresentada à Escola Superior de Agricultura "Luiz de Queiroz", Universidade de São Paulo, para obtenção do título de Doutor em Agronomia, Área de Concentração: Solos e Nutrição de Plantas.

P I R A C I C A B A

Estado de São Paulo - Brasil Agosto - 2003 
TAXAS DE MINERALIZAÇÃO E DE LIXIVIAÇÃO DO NITROGÊNIO, E ALTERAÇÕES DA FERTILIDADE DE UM LATOSSOLO VERMELHOAMARELO DEGRADADO E OUTRO NÃO-DEGRADADO FERTILIZADOS COM BIOSSÓLIDO E FLORESTADOS COM Eucalyptus grandis

\section{MÁRCIA TOFFANI SIMÃO SOARES}

Engenheira Agrônoma

Orientador: Prof. Dr. ADOLPHO JOSÉ MELFI

Tese apresentada à Escola Superior de Agricultura "Luiz de Queiroz", Universidade de São Paulo, para obtenção do título de Doutor em Agronomia, Área de Concentração: Solos e Nutrição de Plantas.

P I R A C I C A B A

Estado de São Paulo - Brasil

Agosto - 2003 


\section{Dados Internacionais de Catalogação na Publicação (CIP)}

DIMSÃO DE BIBLIOTECA E DOCUMENTAÇÃO - ESALQ/USP

\section{Soares, Márcia Toffani Simão}

Taxas de mineralização e de lixiviação do nitrogêncio, e alterações da fertilidade de um latossolo vermelho-a marelo degradado e outro não-degradado fertiliza dos com biossólido e florestados com Eucalyptus grandis / Márcia Toffani Simão Soares. - - Piracicaba, 2003.

142 p. : il.

Tese (doutorado) - Escola Superior de Agricultura Luiz de Queiroz, 2003. Bibliografia.

1. Degradação do solo 2. Eucalipto 3. Fertilida de do solo 4. Lixiviação do solo 5. Lodo de esgoto 6. Latossolo 7. Mineralização de nitrogênio 8. Povoamento florestal I. Título

CDD 634.9734 
“Terra para o pé, firmeza

Terra para a mão, carícia

Outros astros Ihe são guia"

(Caetano Veloso)

Aos meus pais Melchor e Amiltes, pelos inestimáveis esforços para a realização de mais esta etapa, Dedico. 


\section{AGRADECIMENTOS}

Ao Prof. Dr. Adolpho José Melfi, pela oportunidade de realização deste trabalho, pelo exemplo de dedicação e visão científica;

Ao Prof. Dr. José Leonardo M. Gonçalves, por muito ter acrescentado à minha formação, pelo constante apoio e incentivo às minhas atividades de pesquisa;

À Prof. Dr. Célia Regina M. Lauar, pela confiança e pelo exemplo de dedicação e carinho à arte de ensinar;

À Coordenação do Curso de Pós Graduação em Solos e Nutrição de Plantas, pela oportunidade concedida;

À Doutoranda Christiane Teixeira, ao Eng. Florestal Lourenço Alvarez e à graduanda Vanessa Suzana Cavaglieri, pela constância, persistência, amizade, e pelas valiosas contribuições à execução do presente trabalho.

Aos funcionários do NUPEGEL, Sr. Paulo Sebastião, Ms. Sérgio de Jesus, Sra. Clotilde M. Batochio e ao Sr. Dorival Prezzoto e Felipe Prezzoto, por todo cuidado dedicado a este trabalho e à autora;

À Prof. Elke J. Cardoso, por possibilitar o uso do Laboratório de Microbiologia do Solo, e aos técnicos Denise Mescolotti e Luiz Fernando Baldesin, pela contribuição;

A todos os funcionários do Depto. de Solos (Nancy C. Amaral, Bete, Flávia Morales, Luis Silva, Marta, ...) pelos anos de convivência e respeito mútuo;

Aos funcionários da EUCATEX (Eng. Florestal Edward, Sr. Reynaldo, Sr. Marinho e equipe, Sr. Roney, Sr. Milton, Sra. Geani) pelo apoio durante a condução do experimento;

Aos pesquisadores Dra. Brigitte Feighl, Dra. Marisa C. Piccolo e Dr. Carlos C. Cerri, por possibilitarem o uso do Laboratório de Biogeoquímica Ambiental (CENA/USP) e pelo acompanhamento do presente trabalho;

À equipe do Lab. de Biogeoquímica Ambiental (CENA/USP), Mara Piacentini, Lilian A. Campos, Dagmar G. Marchesoni, Luiz H. Koshimizu, e Maria Cristina Rosa;

À Alba Masseto e Fernanda Moniz, do Laboratório de Ecologia Aplicada e ao Jéferson Lordello, 
do Laboratório de Métodos Quantitativos (Departamento de Ciências Florestais, ESALQ/USP); Aos Professores Dr. Paulo Torres Carvalho, Dr. Carlos Tadeu Dias, Dr. G.C. Vitti, Dr. Ezer Dias de Oliveira Jr. (ESALQ, USP) e Pedro Henrique C. Luz (FVZ/USP), aos pesquisadores Dr. Wagner Bettiol (EMBRAPA) e Dr. Ronaldo Berton (IAC), e ao Eng. Agro. José Abrahão Haddad, pelas contribuições, em fases distintas do projeto;

Aos funcionários e estagiários da Biblioteca Central (ESALQ/USP), à equipe "Xerox do CALQ”, e às funcionárias da Seção de Alunos - Pós Graduação, pela paciência com as eternas "urgências" e pela gentileza no atendimento;

Aos amigos Norberto Noronha Cornejo e Sonia Marta Carpinelli, por todo o auxílio e companheirismo dedicados ao longo desta nossa passagem por Piracicaba. "Um amigo representa uma só alma em dois corpos”;

Aos amigos Ms. Christiano A. Andrade e Eng. Agr. Alex Paulus, pelo constante incentivo e amizade, além das contribuições e sugestões;

Aos amigos Ana Maria de Meira, Cláudia Irene, Daniela Medeiros, Silvia Kataoka, Vanderley Stefanuto (a trupe), Elisabeth Lopes, Fernando Martins, Viviane, Marcelino Guedes \& Cláudia Lira, por tornarem especiais o tempo vivido em Piracicaba. "A felicidade é multiplicada quando é compartilhada";

Aos colegas de NUPEGEL, pós-granduandos Adriel, Débora, Vânia, Uwe, Tomas, Sandra, graduandos Wagner e Tiago, e colegas do CENA, Dinailson, Solismar e Marquinho, pela convivência, contribuicões e partilha de experiêncas;

À Equipe de Apoio, Ms. Daniela Takahashi, Dr. Marcos Gama, Dras. Sandra Menegatti e Renee D., Silvia S., Carlinhos, Bene e colaboradoras, pela solidariedade, a minha eterna gratidão; Àqueles que porventura não tenha citado os nomes, mas que favoreceram o presente estudo e a autora, minhas desculpas e agradecimentos sinceros. 


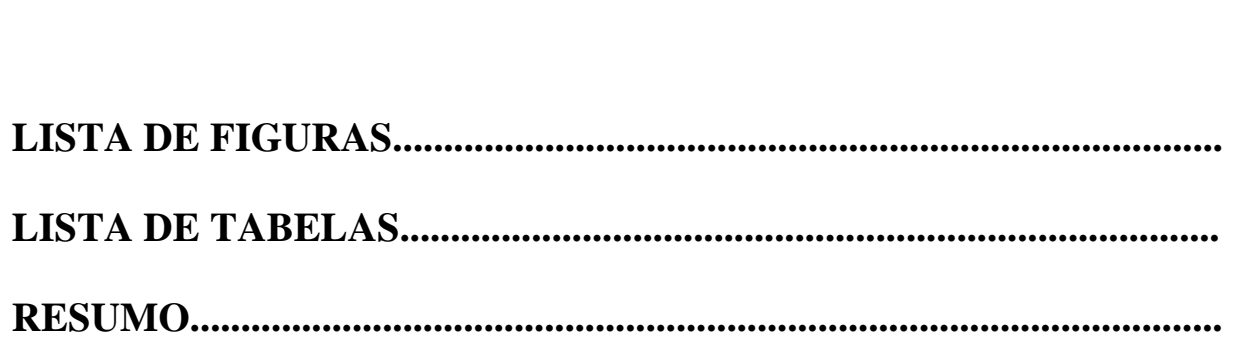

SUMMARY.

1 INTRODUÇÃO

2 REVISÃO DE LITERATURA

2.1 Importância da utilização do biossólido

2.2 Conceito de degradação, recuperação e reabilitação do solo

2.3 Potencial de uso agrícola e florestal de lodo de esgoto

2.3.1 Uso de biossólido em áreas degradadas

2.3.2 Uso de biossólido em ecossistemas florestais

2.4 Efeito da aplicação de biossólido no solo.

2.4.1 Fertilidade do solo....

2.4.2 Riscos de danos ambientais

2.4.3 Dinâmica do N.

2.5 Adequação das quantidades e das épocas de aplicação de biossólido em plantios florestais.

3 MATERIAL E MÉTODOS.

3.1 Caracterização da região e da área de estudo.

3.2 Características do biossólido
25

25

Página

ix

xiii

$\mathrm{XV}$

xvii

1

3

3

4

6

7

9

11

11

16

18

22

28 
3.3 Instalação do experimento, tratamentos e delineamento experimental..

3.4 Caracterização do solo e da serapilheira antes da aplicação do biossólido.

3.5 Amostragem da biomassa residual pós-aplicação do biossólido........... 35

3.6 Taxas de mineralização e de lixiviação de $\mathrm{N}$ in situ................................ 36

3.6.1 Determinação das quantidades de $\mathrm{N}$ mineralizadas e lixiviadas.................................................... 38

3.7 Monitoramento da fertilidade do solo................................................. 40

3.8 Mensuração das árvores...................................................................... 40

3.9 Análise foliar............................................................................ 40

3.10 Monitoramento das condições climáticas............................................ 40

3.11 Métodos laboratoriais de análise....................................................... 41

3.11.1 Análises físicas do solo........................................... 41

3.11.2 Determinações químicas.......................................... 41

3.12 Conteúdo de nutrientes na serapilheira, na mistura serapilheira mais biossólido e de $\mathrm{N}$ mineral no solo.......................................................... 43

3.13 Análises estatísticas........................................................................ 43

4 RESULTADOS E DISCUSSÃO.................................................................... 45

4.1 Caracterização do solo antes da aplicação do biossólido........................ 45

4.2 Biomassa residual e características quimicas de serapilheira e da mistura serapilheira mais biossolido, acumulados sobre o solo............. 49

4.2.1 Biomassa residual............................................... 49

4.2.2 Características químicas........................................... 51

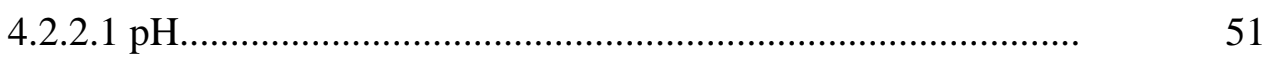

4.2.2.2 Concentração de $\mathrm{C}$ e de $\mathrm{N}$ totais.......................................... 52

4.2.2.3 Concentração de $\mathrm{N}$ mineral.................................................. 54

4.2.2.4 Concentrações e conteúdos de macronutrientes.................... 59

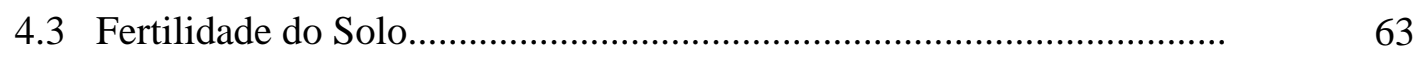


4.3.1 Concentração de $\mathrm{N}$ mineral....................................... 63

4.3.2 Taxas de mineralização e de lixiviação de N............... 65

4.3.2.1 Mineralização de N.......................................................... 65

4.3.2.2 Lixiviação de N............................................................. 70

4.3.2.3 Modelagem da mineralização e da lixiviação de N......... $\quad 74$

4.3.3 Concentrações de $\mathrm{C}$ total, de $\mathrm{N}$ total e de matéria orgânica........................................................... 76

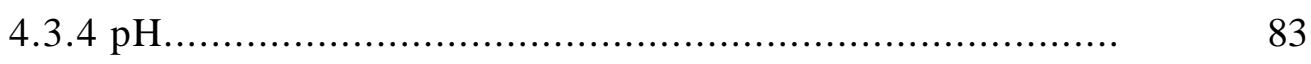

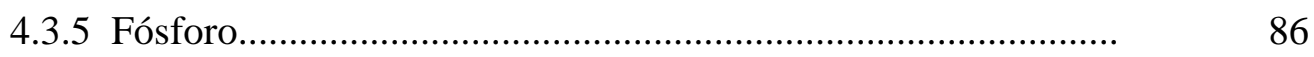

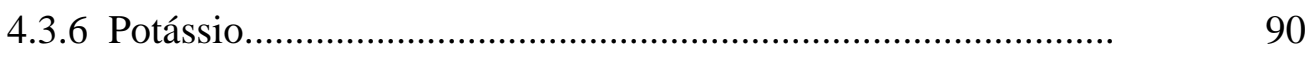

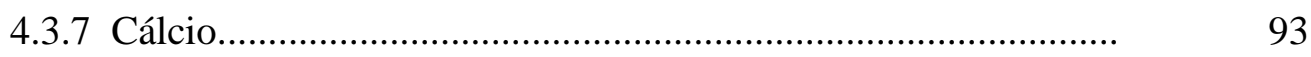

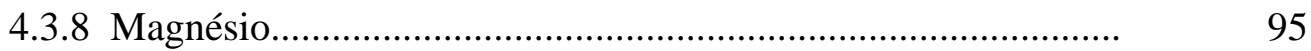

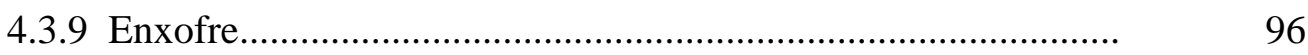

4.4 Nutrição das Árvores....................................................................... 99

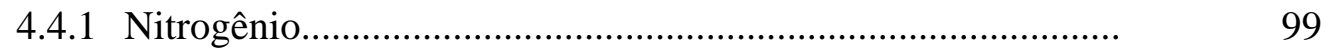

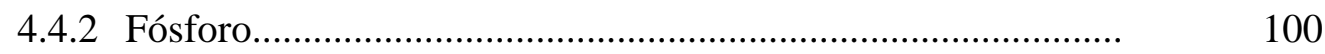

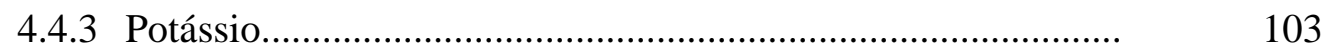

4.4.4 Cálcio e Magnésio..................................................................... 103

4.4.5 Enxofre......................................................................... 104

4.5 Crescimento das árvores.................................................................. 106

5 CONCLUSÕES......................................................................... 118

REFERÊNCIAS BIBLIOGRÁFICAS ..................................................... 121 


\section{LISTA DE FIGURAS}

1 Localização do Município de Salto de Pirapora (SP) e a Fazenda São Paulo, onde o experimento foi instalado.

2 Balanço hídrico da cidade de Salto de Pirapora (SP), segundo Thornthwaite \& Mather (1955) (média de 29 anos)

3 Disposição dos blocos e tratamentos na área experimental. Nas parcelas em cinza foram monitoradas as taxas de mineralização e lixiviação de $\mathrm{N}$

4 Procedimentos para o preparo do solo degradado. (a) Destocamento dos tocos de eucalipto; (b) remoção da serapilheira e do solo; (c) aplicação de 40 t ha ${ }^{-1}$ do biossólido; (d) superfície do solo com $20 \mathrm{t} \mathrm{ha}^{-1}$ (à esquerda) e $40 \mathrm{t} \mathrm{ha}^{-1}$ do biossólido (à direita).

5 Aplicação, em faixas ( $1 \mathrm{~m}$ ), na linha de plantio, de $10 \mathrm{t} \mathrm{ha}^{-1}$ (a e b) e $20 \mathrm{t} \mathrm{ha}^{-1}$ do biossólido (c e d) em solo não-degradado, manejado no sistema de cultivo mínimo. Solo não-degradado (e) e degradado (f) após aplicação do biossólido e subsolagem.

6 Esquema da área experimental, com divisão em partes (P) para as amostragens da serapilheira e do solo antes da aplicação do biossólido.

7 Instalação e retirada dos tubos de PVC para avaliação das taxas de mineralização e de lixiviação de $\mathrm{N}$ in situ, em solo degradado, que recebeu $20 \mathrm{t} \mathrm{ha}{ }^{-1}$ de biossólido.

8 Tubo de PVC em solo não-degradados que recebeu $20 \mathrm{t} \mathrm{ha}^{-1}$ do biossólido, usado para avaliação das taxas de mineralização e de lixiviação de N in situ (março 2002)

9 Concentrações de $\mathrm{C}$ total (a), de $\mathrm{N}$ total (b) e relação $\mathrm{C} / \mathrm{N}$ (c) (média \pm erro padrão) na serapilheira e serapilheira mais biossólido aos sete (1) e aos doze meses (2) pós-aplicação do biossólido, nos diferentes tratamentos (solo não-degradado).

10 Concentração de $\mathrm{N}$ mineral $\left(\mathrm{N}_{-} \mathrm{NH}_{4}{ }^{+}+\mathrm{N}^{-} \mathrm{NO}_{3}{ }^{-}\right)$(média \pm erro padrão) na serapilheira, na serapilheira mais biossólido (20 t ha ${ }^{-1}$ ) no solo não-degradado e no biossólido puro (20 t ha 1) aplicado no solo degradado.

11 Precipitação, temperaturas média, máxima e mínima mensal durante os oito primeiros meses do experimento (agosto de 2001 a abril de 2002), com as indicações dos períodos de incubação do solo in situ em tubos de PVC.... 
12 Temperaturas mínima e máxima do solo (a $5 \mathrm{~cm}$ de profundidade) não-degradado e degradado, durante os sete primeiros meses pós-aplicação do biossólido.

13 Concentração deN- $\mathrm{NH}_{4}{ }^{+}$(a) e $\mathrm{N}_{-} \mathrm{NO}_{3}{ }^{-}$(b) (média \pm erro padrão) na serapilheira, na serapilheira mais biossólido (20 t ha $\left.\mathrm{t}^{-1}\right)$ no solo não-degradado e no biossólido puro (20 t ha $\left.\mathrm{a}^{-1}\right)$ aplicado no solo degradado

14 Distribuição de $\mathrm{N}$ mineral $\left(\mathrm{N}_{-} \mathrm{NH}_{4}{ }^{+}+\mathrm{N}^{-} \mathrm{NO}_{3}{ }^{-}\right.$) (média \pm erro padrão) no perfil do solo (0-30 cm) nos sete primeiros meses pós-aplicação do biossólido.

15 Taxa de mineralização de $\mathrm{N}\left(\mathrm{N}_{-} \mathrm{NH}_{4}{ }^{+}+\mathrm{N}-\mathrm{NO}_{3}{ }^{-}\right)$na camada 0-30 $\mathrm{cm}$ (média \pm erro padrão) do solo não-degradado, sem e com aplicação de $20 \mathrm{t} \mathrm{ha}^{-1}$ do biossólido, e do solo degradado que recebeu $20 \mathrm{t} \mathrm{ha}^{-1}$ do biossólido.

16 Taxas de amonificação (a) e nitrificação (b) na camada 0-30 cm (média \pm erro padrão) do solo não-degradado, sem e com aplicação de $20 \mathrm{t} \mathrm{ha}^{-1}$ do biossólido, e do solo degradado que recebeu $20 \mathrm{t} \mathrm{ha}^{-1}$ do biossólido.

17 Taxa de lixiviação de $\mathrm{N}$ mineral total $\left(\mathrm{N}_{-} \mathrm{NH}_{4}{ }^{+}+\mathrm{N}^{-} \mathrm{NO}_{3}{ }^{-}\right)$na camada $0-30 \mathrm{~cm}$ (média \pm erro padrão) do solo não-degradado, sem e com aplicação de $20 \mathrm{t} \mathrm{ha}^{-1}$ do biossólido, e do solo degradado que recebeu $20 \mathrm{t} \mathrm{ha}^{-1}$ do biossólido.

18 Taxas de lixiviação de $\mathrm{N}_{-} \mathrm{NH}_{4}{ }^{+}$(a) e $\mathrm{N}^{-\mathrm{NO}_{3}}{ }^{-}$(b) na camada 0-30 cm (média \pm erro padrão) do solo não-degradado, sem e com aplicação de $20 \mathrm{t} \mathrm{ha}^{-1}$ do biossólido, e do solo degradado que recebeu $20 \mathrm{t} \mathrm{ha}^{-1}$ do biossólido.

19 Concentração de C total (média \pm erro padrão) aos sete (1) e aos doze (2) meses pósaplicação do biossólido, nas camadas 3-10 (a) e 10-20 cm (b) do solo não-degradado e degradado, nos diferentes tratamentos..

20 Concentração de $\mathrm{N}$ total (média \pm erro padrão) aos sete (1) e aos doze (2) meses pósaplicação do biossólido, nas camadas 10-20 (a) e 20-30cm (b) do solo não-degradado e degradado, nos diferentes tratamentos......

21 Relação C/N (média \pm erro padrão) aos sete (1) e aos doze meses (2) pós-aplicação do biossólido, nas camadas 0-3 (a), 10-20 (b) e 20-30 (c) cm do solo não-degradado e degradado, nos diferentes tratamentos......

22 Concentração de matéria orgânica (média \pm erro padrão) aos sete (1) e aos doze (2) meses pós-aplicação do biossólido, nas camadas 0-3 (a) e 3-10 cm (b) do solo não-degradado e degradado, nos diferentes tratamentos

23 Concentração de matéria orgânica (média \pm erro padrão) aos sete (1) e aos doze (2) meses pós-aplicação do biossólido, nas camadas 10-20 (a) e 20-30 cm (b) do solo não-degradado e degradado, nos diferentes tratamentos. 
24 pH (média + erro padrão) aos sete (1) e aos doze (2) meses pós-aplicação do biossólido, nas camadas 0-3 (a), 10-20 (b) e 20-30 cm (c) do solo não-degradado e degradado, nos diferentes tratamentos

25 Concentração de P-resina (média + erro padrão) aos sete (1) e aos doze (2) meses pósaplicação do biossólido, nas camadas 0-3 (a), 3-10 (b) e 20-30 cm (c) do solo nãodegradado e degradado, nos diferentes tratamentos.

26 Concentração de K trocável (média \pm erro padrão) aos sete (1) e aos doze (2) meses pósaplicação do biossólido, na camada 3-10 cm (a) do solo não-degradado e degradado, nos diferentes tratamentos

27 Concentração de Ca (média — erro padrão) aos sete (1) e aos doze (2) meses pós-aplicação do biossólido, nas camadas 0-3 (a) e 3-10 cm (b) do solo não-degradado e degradado, nos diferentes tratamentos.

28 Concentração de Mg (média + erro padrão) aos sete (1) e aos doze meses (2) pós-aplicação do biossólido, nas camadas 0-3 (a) e 3-10 cm (b) do solo não-degradado e degradado, nos diferentes tratamentos.

29 Concentração de $\mathrm{S}_{-} \mathrm{SO}_{4}{ }^{2-}$ (média \pm erro padrão) aos sete (1) e aos doze (2) meses pósaplicação do biossólido, nas camadas 0-3 (a), 3-10 (b), 10-20 (c) e 20-30 cm (d) cm do solo não-degradado e degradado, nos diferentes tratamentos.

30 Concentrações foliares de $\mathrm{N}$ (a) aos três meses, de N (a), de K (b) e de P (c) (média \pm erro padrão) aos sete (1) e aos doze meses (2) pós-aplicação do biossólido, nos tratamentos em solo não-degradado e degradado.

31 Concentrações foliares de Ca (a), de Mg (b) e de S (c) (média \pm erro padrão) aos sete (1) e aos doze (2) meses pós-aplicação do biossólido, nos tratamentos em solo não-degradado e degradado.

32 Altura (a) e diâmetro à altura do peito (DAP) (b) das árvores aos sete (1), aos doze (2) e aos vinte e dois meses (3) pós-aplicação do biossólido, nos tratamentos em solo não-degradado e degrado

33 Eucalyptus grandis aos três meses pós-aplicação do biossólido, no solo não-degradado que recebeu $20 \mathrm{t} \mathrm{ha}^{-1}$ de biossólido mais PK (tratamento 4) (a) e no solo degradado, sem aplicação de biossólido (tratamento 7) (b)

34 Eucalyptus grandis aos sete meses pós-aplicação do biossólido, no solo degradado sem biossólido (tratamento 7) (a); solo degradado sem aplicação de biossólido (tratamento 7, à esquerda) e que recebeu $20 \mathrm{t} \mathrm{ha}^{-1}$ de biossólido mais PK (tratamento 8, à direita) (b).

35 Eucalyptus grandis aos sete meses pós-aplicação do biossólido, no solo não-degradado sem aplicação de biossólido (Controle, tratamento 1) (a), e que recebeu $20 \mathrm{t} \mathrm{ha}^{-1}$ de biossólido mais PK (tratamento 4) (b). 
36 Eucalyptus grandis aos doze meses pós-aplicação do biossólido, no solo degradado sem aplicação do biossólido (Controle, tratamento 7) (a) e que recebeu $20 \mathrm{t} \mathrm{ha}^{-1}$ de biossólido mais PK (tratamento 8) (b) 


\section{LISTA DE TABELAS}

1 Composição do biossólido tipo B produzido pela Estação de Tratamento de Esgoto de Barueri, SABESP/SP (agosto 2001). .28

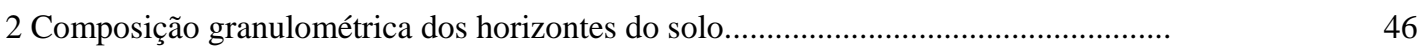

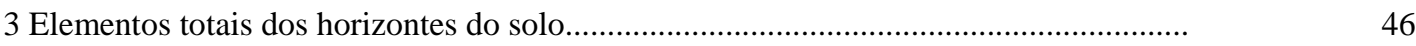

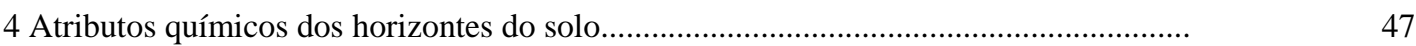

5 Composição granulométrica das diferentes camadas do solo, após a remoção da camada superficial e antes da aplicação do biossólido..................................................................... 47

6 Densidade do solo (média \pm erro padrão) logo após a instalação do experimento

7 Composição química das camadas do solo avaliadas no experimento, antes da aplicação do biossólido.

8 Biomassa residual da serapilheira e da mistura serapilheira mais biossólido na faixa de 1 metro de aplicação do biossólido (média \pm desvio padrão), aos sete e aos doze meses pósaplicação do biossólido (PAB), e diminuição da massa da serapilheira entre sete e doze meses PAB...

9 Variação do pH da serapilheira e da mistura serapilheira mais biossólido nos primeiros sete meses pós-aplicação do biossólido (PAB)

10 Concentração de macronutrientes (média \pm desvio padrão) na serapilheira e na mistura serapilheira mais biossólido, antes da instalação do experimento, aos sete e aos doze meses pós-aplicação do biossólido (PAB), nos tratamentos em solo não-degradado.

11 Conteúdo de nutrientes na serapilheira e na mistura serapilheira mais biossólido (média \pm desvio padrão) acumulados na superfície do solo antes da instalação do experimento, aos sete e aos doze meses pós-aplicação do biossólido (PAB), nos tratamentos em solo nãodegradado.

12 Taxas mensais de mineralização e de lixiviação de $\mathrm{N}$, e quantidades totais de $\mathrm{N}$ mineralizado e lixiviado nos sete primeiros meses pós-primeira incubação (PPI) do solo, na camada 0-30 cm do solo, obtidas pelas equações de regressão, em diferentes tratamentos. 
13 Variação do pH nos primeiros sete meses pós-aplicação do biossólido (PAB), no solo nãodegradado sem e com $20 \mathrm{t} \mathrm{ha}^{-1}$ de biossólido, e no solo degradado com $20 \mathrm{t} \mathrm{ha}^{-1}$ de biossólido.

14 Concentração de K trocável no solo em diferentes tratamentos (média \pm erro padrão), aos sete e aos doze meses pós-aplicação do biossólido (PAB)..

15 Análise de variância da regressão múltipla para as variáveis dependentes altura e diâmetro à altura do peito (DAP), aos sete e aos doze meses pós-aplicação do biossólido (PAB), nos tratamentos em solo não-degradado com suplementação de P e K

16 Equações de regressão múltipla que relacionam a altura e o diâmetro à altura do peito (DAP) das árvores com as concentrações de macronutrientes foliares aos sete e aos doze meses pós- aplicação do biossólido, nos tratamentos em solo não-degradado com suplementação de P e K.

17 Análise de variância da regressão múltipla para as variáveis dependentes altura e diâmetro à altura do peito (DAP), aos sete e aos doze meses pós-aplicação do biossólido (PAB), nos tratamentos em solo degradado.

18 Equações de regressão múltipla que relacionam a altura e diâmetro à altura do peito (DAP) das árvores com as concentrações de macronutrientes foliares, aos sete e aos doze meses pós-aplicação do biossólido, nos tratamentos em solo degradado. 


\title{
TAXAS DE MINERALIZAÇÃO E DE LIXIVIAÇÃO DO NITROGÊNIO, E ALTERAÇÕES DA FERTILIDADE DE UM LATOSSOLO VERMELHO- AMARELO DEGRADADO E OUTRO NÃO-DEGRADADO FERTILIZADOS COM BIOSSÓLIDO E FLORESTADOS COM Eucalyptus grandis
}

\author{
Autor: MÁRCIA TOFFANI SIMÃO SOARES \\ Orientador: Prof. Dr. ADOLPHO JOSÉ MELFI
}

\section{RESUMO}

Este estudo teve como objetivo avaliar os efeitos da aplicação de biossólido sobre as taxas de mineralização e de lixiviação de $\mathrm{N}$, as modificações de fertilidade do solo, a nutrição e o crescimento de povoamentos de Eucalyptus grandis plantados em um Latossolo Vermelho-Amarelo Distrófico não-degradado (sob cultivo mínimo) e outro degradado. O experimento foi conduzido no município de Salto de Pirapora, SP. A área experimental foi constituída de quatro blocos e nove tratamentos; em três tratamentos, a camada superficial do solo $(0-20 \mathrm{~cm})$ foi removida (solo degradado). Os tratamentos na área com solo não-degradado, cultivado no sistema de cultivo mínimo, foram: (1) Controle, (2) Fertilização mineral, (3) $10 \mathrm{t} \mathrm{ha}^{-1}$, (4) 20 e (5) $40 \mathrm{t} \mathrm{ha}^{-1}$ de biossólido (base seca), todos com suplementação de $\mathrm{P}$ e $\mathrm{K}$, e (6) $10 \mathrm{t} \mathrm{ha}^{-1}$ de biossólido, sem suplementação de $\mathrm{P}$ e $\mathrm{K}$; na área com solo degradado, os tratamentos foram: (7) Controle, (8) 20 e (9) $40 \mathrm{t} \mathrm{ha}^{-1}$ de biossólido, todos com suplementação de P e K. Nos tratamentos 1, 4 e 8 foram monitoradas as taxas de mineralização e de lixiviação de N no solo. No solo não-degradado, nos primeiros sete meses pós-aplicação do biossólido (PAB), houve aumento das taxas de mineralização de $\mathrm{N}$, do $\mathrm{pH}$, da concentração de $\mathrm{P}$ - 
resina, e diminuição das concentrações de K, Ca e Mg trocáveis. Aos doze meses PAB, as concentrações de P-resina aumentaram, e as de matéria orgânica e $\mathrm{N}$ total diminuíram. As concentrações foliares de $\mathrm{N}$ aumentaram aos três meses, de $\mathrm{N}$ e P aos sete meses, e as de $\mathrm{K}$ diminuíram aos doze meses PAB. No solo degradado que recebeu $20 \mathrm{t} \mathrm{ha}^{-1}$ de biossólido, as quantidades de $\mathrm{N}$ mineralizadas, em sete meses, foram semelhantes às obtidas no não-degradado sem biossólido, e as taxas de lixiviação de $\mathrm{N}$ foram maiores do que no solo não-degradado com a mesma dose. Nesta época, no solo degradado, o biossólido aumentou concentrações de P-resina, Ca, Mg e S, o pH somente na camada 0-3 cm e, aos doze meses, aumentou as concentrações de $\mathrm{C}$, $\mathrm{N}$ totais, de matéria orgânica, de P-resina, de Ca trocável, e diminuiu e aumentou, respectivamente, as concentrações de $\mathrm{S}$ nas camadas 0-3 e 3-30 cm do solo. Houve aumento das concentrações foliares de N, aos três meses, de N, P, Mg e S aos sete meses, e de Ca aos doze meses PAB. O biossólido aumentou as taxas de crescimento do E. grandis, aos sete meses $\mathrm{PAB}$, nas duas condições de solo e, aos doze e aos vinte e dois meses PAB, nos tratamentos em solo degradado. No tratamento em solo degradado que recebeu $40 \mathrm{t} \mathrm{ha}^{-1}$ de biossólido, as árvores tiveram crescimento semelhante ao dos tratamentos em solo não-degradado. Nas duas condições de solo, as variâncias entre tratamentos relativas ao crescimento das árvores foram explicadas principalmente pela maior absorção de $\mathrm{N}$ pelas plantas. 


\title{
MINERALIZATION AND LEACHING OF NITROGEN, AND FERTILITY MODIFICATIONS OF A DEGRADED AND NON-DEGRADED RED-YELLOW LATOSOL, AMENDED WITH BIOSOLID AND CULTIVATED WITH Eucalyptus grandis
}

\author{
Author: MÁRCIA TOFFANI SIMÃO SOARES
}

Adviser: PROF. DR. ADOLPHO JOSÉ MELFI

\section{SUMMARY}

The aim of this study was to evaluate the effects of biosolid application on the mineralization and leaching rates of $\mathrm{N}$, the changes of soil fertility, nutrition and growth of Eucalyptus grandis cultivated in a non-degraded (under minimum tillage) and in a degraded Red-Yellow Latosol (Oxissol). It was carried out in Salto do Pirapora district, São Paulo State, Brazil. The experimental area included four blocks and nine treatments; in three of them, the topsoil $(0-20 \mathrm{~cm})$ was removed (degraded soil). Treatments in the non-degraded soil area, cultivated under minimum-tillage system, were: (1) Control, (2) Mineral fertilization, (3) $10 \mathrm{t} \mathrm{ha}^{-1}$, (4) 20 and (5) $40 \mathrm{t} \mathrm{ha}^{-1}$ of biosolid, all supplemented with $\mathrm{P}$ and $\mathrm{K}$ and (6) $10 \mathrm{t} \mathrm{ha}^{-1}$ of biosolid with no $\mathrm{P}$ and $\mathrm{K}$ supplementation; in the degraded soil area, the treatments were: (7) Control, (8) 20 and (9) $40 \mathrm{t} \mathrm{ha}^{-1}$ of biosolid, all supplemented with $\mathrm{P}$ and $\mathrm{K}$. Mineralization and leaching rates of $\mathrm{N}$ in the soil were monitored in treatments 1, 4 and 8. In non-degraded soils, on the first seven months after biosolid application (ABA), increasing of $\mathrm{N}$ mineralization rates, $\mathrm{pH}$, concentration of the soil P-resin, and decreasing concentrations of exchangeable $\mathrm{K}$, $\mathrm{Ca}$ and $\mathrm{Mg}$ were observed. Twelve months ABA, P-resin concentrations increased, and organic matter 
and total $\mathrm{N}$ decreased. $\mathrm{N}$ concentration in foliage increased at three months, $\mathrm{N}$ and $\mathrm{P}$ at seven months and $\mathrm{K}$ decreased at twelve months FBA. The amounts of mineralized $\mathrm{N}$ in the degraded soil with biosolid (20 t ha ${ }^{-1}$ ), at seven months, were similar to those achieved in the Control under non-degraded soil; $\mathrm{N}$ leaching was higher in degraded than those in non-degraded soil with the same amount of biosolid. In that age, in degraded soil, the biosolid increased the concentrations of P-resin, $\mathrm{Ca}, \mathrm{Mg}$ and $\mathrm{S}$ and $\mathrm{pH}$, only at 0-3 cm layer and, at twelve months, increased the total $\mathrm{C}$ and $\mathrm{N}$, organic matter, P-resin, exchangeable Ca, and S concentrations decreased in 0-3 and increased in 3-30 cm layers. N, P, Mg and S concentrations in foliage increased at seven months and $\mathrm{Ca}$ at twelve months $\mathrm{ABA}$. The biosolid increased the growth rates of $E$. grandis at seven months $\mathrm{ABA}$ in both soil conditions, and at twelve and twenty-two months $\mathrm{ABA}$ in degraded soil. In degraded soil treatment that received $40 \mathrm{t} \mathrm{ha}^{-1}$ of biosolid, the growth of trees was similar to those of non-degraded soil treatments. In both soil conditions, the variances between treatments regarding tree growth were explained mainly by higher plants $\mathrm{N}$ uptake. 


\section{INTRODUÇÃO}

As graves implicações sociais, econômicas e ambientais vinculadas à falta de saneamento básico no país têm induzido a sociedade e os órgãos públicos a busca de soluções técnicas viáveis e integradas para a solução deste problema. No caso da produção de esgoto doméstico, sua coleta e tratamento em estações de tratamento de esgoto (ETE) têm contribuído significativamente para a melhoria das condições sanitárias e diminuição da poluição ambiental. Contudo, estas medidas solucionam o problema parcialmente, pois outros resíduos são gerados, como o efluente de esgoto tratado e o lodo de esgoto; este último, quando passível de uso sem danos ambientais, é denominado biossólido.

Como alternativa de disposição do biossólido, tem-se estudado o seu uso em áreas agrícolas. Com isso, os custos com aterros sanitários e suas conseqüências adversas (proliferação de vetores biológicos transmissores de doenças e a contaminação do solo, da água e do ar) são diminuídos. Por outro lado, o uso de biossólido para produção vegetal possibilita a reciclagem de nutrientes, com substancial economia de fertilizantes minerais. Devido à sua riqueza em matéria orgânica, seu potencial como agente de desenvolvimento da estrutura do solo é muito expressivo. Com essas vantagens, o biossólido constitui um insumo muito promissor para a recuperação de solos degradados.

Os estudos sobre este tema, em ambientes florestais e de solos degradados, se intensificaram nas décadas de 80 e 90, principalmente em países de clima temperado (McNab \& Berry, 1985; Phillips et al., 1986; Sopper, 1992; Dutch et al., 1994; Harrison et al., 1994; Henry et al., 1994; Harrison et al., 1996; Daniels \& Haering, 1994; Navas et al., 1999). Em condições tropicais, há poucos estudos, de modo que o conhecimento 
sobre o uso de biossólido em plantações florestais é considerado incipiente, com várias lacunas científicas e técnicas.

Para avaliar as modificações dos ecossistemas florestais que receberam biossólido, o acompanhamento periódico da fertilidade do solo, da nutrição e do crescimento das plantas é imprescindível. Desta forma, é possível detectar efeitos benéficos e nocivos, às vezes, em curto prazo, como a disponibilidade e a relação entre nutrientes no solo, e o potencial de contaminação do lençol freático com $\mathrm{N}_{-} \mathrm{NO}_{3}{ }^{-}$.

Neste contexto, este estudo teve como objetivos avaliar os efeitos da aplicação de biossólido sobre as taxas de mineralização e lixiviação de $\mathrm{N}$, as modificações de fertilidade do solo, a nutrição e o crescimento de povoamentos de Eucalyptus grandis plantados em um Latossolo Vermelho-Amarelo Distrófico nãodegradado e outro degradado. 


\section{REVISÃO DE LITERATURA}

\subsection{Importância da utilização do biossólido}

O gerenciamento dos resíduos urbanos é considerado como um dos mais importantes desafios ambientais mundiais a serem enfrentados pela humanidade. No mundo, dois bilhões de pessoas estão expostas a doenças, e dois milhões morrem, anualmente, em conseqüência da falta de saneamento básico. Dados da ONU indicam que dez por cento da população dos países em desenvolvimento são afetadas por infecções intestinais provocadas por vermes (United Nation Environment Programme UNEP, 2003) e, no Brasil, 65\% das internações hospitalares de crianças com idades menores que 10 anos estão associadas à falta de saneamento básico (Banco Nacional de Desenvolvimento Econômico e Social - BNDES, 1998).

Embora a gestão adequada dos resíduos tenha sido evidenciada por conferências nacionais e internacionais como item de fundamental relevância para a qualidade do meio ambiente, desenvolvimento social e econômico de uma nação (Conferência das Nações Unidas Sobre o Meio Ambiente e Desenvolvimento, 1997), a situação do saneamento básico nos países considerados em desenvolvimento ainda está distante do adequado. No Brasil, estima-se que 47,8\% dos municípios não têm serviço de esgoto sanitário e menos de $10 \%$ da população têm esgoto tratado. Dos 14,5 milhões de metros cúbicos de esgoto coletado diariamente no país, somente 5,1 milhões recebem tratamento (35\% do total) (Instituto Brasileiro de Geografia e Estatística - IBGE, 2002). Estes números indicam, além da necessidade de construção de mais sistemas de 
tratamento de esgoto, o potencial de produção crescente de lodo de esgoto no país. No estado de São Paulo, por exemplo, estima-se para a Região Metropolitana, no ano de 2015, que cerca de 286 mil toneladas anuais de lodo em base seca (785 toneladas por dia) serão produzidos (Tsutya, 2000). Grande parte do lodo atualmente gerado nos sistemas de tratamento no país tem como destino final os aterros sanitários, sistema oneroso e que limita a reciclagem e reaproveitamento do resíduo. Esta situação no setor de saneamento gera problemas graves de ordem sanitária, ambiental e de saúde pública.

Os valores supracitados expressam a importância de um planejamento estratégico para o manejo e a disposição adequados do esgoto e de seus subprodutos, que visem a sanidade ambiental e da comunidade. Em relação ao lodo de esgoto, muitas alternativas já foram estudadas, como seu emprego em materiais de construção (agregado leve e tijolos), pirólise e fonte de energia (Tsutyia, 2000). Os países desenvolvidos utilizam a incineração $(10,9 \%)$, aterros sanitários $(41,6 \%)$, uso agrícola $(36,4 \%)$ e emprego em solos sob florestas e degradados (6\%) como as alternativas mais viáveis (Amarante, 1997). Destas alternativas, a aplicação de lodo no solo é considerada menos custosa e ambientalmente mais vantajosa (Ohio Environmental Protection Agency, 2000).

\subsection{Conceito de degradação, recuperação e reabilitação do solo}

De acordo com o uso do solo, a definição de degradação pode variar. O Instituto Brasileiro do Meio Ambiente e dos Recursos Naturais e Renováveis - IBAMA (1990) define que a degradação de uma área ocorre em um destes casos: (i) quando a vegetação nativa e a fauna forem destruídas, removidas ou expulsas, (ii) a camada fértil do solo for perdida, removida ou enterrada e (iii) a qualidade e regime de vazão do sistema hídrico for alterado. Específicamente para solo, Curi et al. (1993) definem degradação como a mudança de um solo a uma condição mais lixiviada e intemperizada que a presente em condições normais, usualmente acompanhada por mudanças 
morfológicas. Gonçalves ${ }^{1}$ apresenta um conceito mais detalhado de degradação em relação ao sistema solo, definindo como aquele que sofreu perda parcial ou total de sua capacidade de sustentar o crescimento de plantas e outros organismos, por meio da degradação de atributos físicos, químicos ou biológicos do solo, altamente interdependentes, pela ação nefasta da atividade humana.

Termos como "recuperação", "reabilitação" e "restauração" são geralmente utilizados como sinônimo de um único processo. Majer ${ }^{2}$, citado por Dias \& Griffith (1998) considera "recuperação" um termo genérico, abrangendo qualquer processo que resulte na obtenção de uma nova utilização para a área degradada. Para o mesmo autor, "reabilitação" do solo representa o retorno da área a um estado biológico apropriado, que não necessariamente significa o seu uso produtivo em longo prazo. Gonçalves et al. (2002), para ecossistemas agrícolas e silvícolas, definiram, "recuperação", como o conjunto de ações destinadas à recuperação da capacidade do solo de sustentar o crescimento de plantas e outros organismos. Segundo o mesmo autor, o processo é contínuo e lento, devendo contemplar, de forma sistêmica, todos os atributos e funções do solo, por isso, apresentando grande complexidade.

Pelas definições supracitadas, são passíveis de uso em ecossistemas agrícolas e silvícolas tanto os termos "recuperação" como "reabilitação". "Restauração" é uma palavra imprópria para tal uso, pois refere-se à obrigatoriedade ao retorno do estado original da área, antes da degradação (Dias \& Griffith, 1998).

De acordo com a United Nations Environment Programme (UNEP) (2003), aproximadamente dois bilhões de hectares de solo, equivalentes a $15 \%$ de toda a superfície de terra do planeta, são hoje classificadas como degradadas pela atividade humana. Uma sexta parte destas áreas (305 milhões de hectares) de solo é considerada

\footnotetext{
${ }^{1}$ GONÇALVES, J.L.M. (Escola Superior de Agricultura "Luis de Queiroz", Universidade de São Paulo, São Paulo, SP). Recuperação de solos degradados. In: KAGEYAMA, P; OLIVEIRA, R.E. Restauração ecológica de ecossistemas naturais no Brasil. (Em elaboração)

${ }^{2}$ MAJER, J.D. Fauna studies and land reclamation technology: a review of the history and need for such studies. In: Majer, J.D. (Coord.) Animals in primary sucession: the role of fauna in reclamed lands. London: Cambridge University Press, 1989, p.3-33.
} 
intensa ou extremamente degradada ${ }^{3}$. Estes valores ainda não consideram o conceito de qualidade do solo, que inclui o critério de sustentabilidade do sistema em longo prazo, ou seja, além da capacidade de produzir biomassa, reciclar nutrientes, estocar carbono, armazenar água, tamponar processos de acidificação ocasionados por atividades antropogênicas e regular transformações de energia (Schoenholtz et al., 2000).

\subsection{Potencial de uso agrícola e florestal de lodo de esgoto}

O lodo de esgoto urbano utilizado para fins agrícolas e florestais é denominado biossólido, termo proposto pela Water Environmental Federation (1993), e definido como o material removido durante o tratamento de esgotos sanitários ou industriais que tenha passado por uma decomposição microbiológica parcial e que seja passível de utilização, sem criar impactos negativos ao meio ambiente (Melo \& Marques, 2000). O termo foi criado no final da década de 80 nos Estados Unidos, com o objetivo de evitar o preconceito e atrair a atenção dos agricultores para o potencial agrícola do lodo de esgoto tratado (Ludovice, 1998).

Nos EUA, a aplicação de biossólido na agricultura é prática comum há mais de quarenta anos. Atualmente 1/3 do lodo gerado naquele país é aplicado no solo, sendo mais de 65\% destinado a solos agrícolas (Shearer \& Shearer, 2000). No Brasil esta forma de disposição ainda é pouco explorada, sendo, em grande parte, utilizada ainda em caráter experimental.

A disposição final do lodo de esgoto em aterros sanitários pode representar 40 a $60 \%$ do custo de operação das estações de tratamento (Centro Nacional de Referência e Gestão Ambiental e Urbana, 2002). Além de onerosa, esta forma de disposição provoca sérios danos de ordem sanitária e ambiental, como a proliferação de vetores biológicos transmissores de doenças, a contaminação do solo e das águas de superfície e subsuperfície e a contaminação do ar pela liberação de odores e gases

\footnotetext{
${ }^{3}$ De acordo com o a United Nations Environment Programme (UNEP) (2003), um solo é considerado extremamente degradado quando não pode ser recuperado.
} 
tóxicos. Esses problemas vêm causando preocupações aos órgãos públicos competentes, que procuram soluções técnicas economicamente viáveis para solucioná-los.

O uso agronômico do biossólido como fonte de nutrientes e como condicionador de solos vem sendo testado em diversos locais do país, principalmente nas regiões vizinhas das grandes cidades (Silva et al., 1996). Já a aplicação deste resíduo para a recuperação de áreas degradadas é prática utilizada há algum tempo na Europa e Estados Unidos, mas pouco estudada nas condições tropicais. Embora seja uma técnica de grande potencial em nosso país, é imprescindível avaliar o potencial de uso e restrições vinculadas ao seu manejo nas condições de clima tropical, em especial em ecossistemas já debilitados.

\subsubsection{Uso de biossólido em áreas degradadas}

O uso de biossólido em sistemas de recuperação de áreas degradadas é considerado por muitos como uma alternativa viável e tecnicamente adequada para reverter a degradação ambiental e restaurar a cobertura vegetal (Sopper, 1992; Daniels \& Haering, 1994; Logan et al., 1994; Navas et al., 1999). Seu uso favorece o solo ou substrato com os benefícios intrínsecos à matéria orgânica, podendo reabilitar solos que sofreram profundas alterações físicas, químicas e, conseqüentemente, que apresentam condições impróprias ao desenvolvimento da vegetação. Também converge com as exigências da sociedade em reabilitar áreas com solos em estágios avançados de degradação e/ou áreas degradadas em decorrência de atividades antrópicas. No entanto, seu uso benéfico depende de uma série de fatores, relativos às características do meio a ser aplicado o resíduo, ao tipo, à quantidade, à periodicidade do uso do biossólido, ao manejo do ambiente após a aplicação e à proteção do solo, da fauna e da qualidade das águas superficiais e subterrâneas.

Em ambientes degradados, a aplicação de biossólido contribui para a diminuição da erodibilidade do solo, pelos benefícios da matéria orgânica no solo (Tester, 1990) e pelo estímulo ao maior crescimento da fitomassa aérea (Meyer et al., 
2001; Castro et al., 2002). Experiência com o uso de biossólido na recuperação de pastagens degradadas e solos semi-áridos é relatada por Pierce et al. (1998). Meyer et al. (2001), incorporando biossólido compostado (0, 40 e $\left.80 \mathrm{t} \mathrm{ha}^{-1}\right)$ a um solo sob floresta submetida à severa queimada (comum nos EUA), observaram perdas de água de chuva via escoamento superficial variando de 18 a $53 \%$ no tratamento controle, valores bem superiores aos observados nas parcelas que receberam $40 \mathrm{t} \mathrm{ha}^{-1}$ (variação de 1 a $12 \%$ ) e 80 t ha $^{-1}$ de biossólido (0,5 a 22\%). Daniels \& Haering (1994), avaliando cinco anos de aplicacão de biossólido compostado $\left(25,50,100 \mathrm{e} 150 \mathrm{t} \mathrm{ha}^{-1}\right)$ em área de mineração de carvão, observaram que a correta aplicação e monitoramento do solo, da vegetação e da água não permitiu a ocorrência de riscos ambientais durante a recuperação do sítio estudado. Em condições tropicais, Bezerra et al. (2002), avaliando doses crescentes de biossólido $\left(0,2,5,5,7,11,4\right.$ e 22,8 $\left.\mathrm{t} \mathrm{ha}^{-1}\right)$ no crescimento de leguminosas em área degradada, observaram respostas positivas da espécie Mimosa caesalpiniifolia (Sabiá) ao biossólido, ao passo que a espécie Mimosa bimucronata (Maricá) teve crescimento inibido com o aumento das doses, indicando necessidade de pesquisas para se avaliar a tolerância de espécies nativas ao uso de resíduos orgânicos.

Pesquisas avaliando o efeito da aplicação de biossólido como fertilizante e condicionador do solo têm sido conduzidas na Europa e Estados Unidos desde a década de 70, em sistemas com diferentes tipos de degradação. No entanto, mesmo nos países que já utilizam a algum tempo biossólido, as técnicas de aplicação em áreas de recuperação não estão, ainda, bem delineadas. Nos EUA, geralmente realiza-se uma única aplicação de grandes quantidades de biossólido, que podem chegar a $495 \mathrm{t} \mathrm{ha}^{-1}$ (Estados Unidos, 1995). O uso de elevadas doses de biossólido em recuperação de áreas degradadas é justificado por Sopper (1992), pelo restabelecimento de diversas funções no solo e pelas vantagens relativas aos custos de uma aplicação única. Com esta prática é possível quantificar, com maior acuidade, a entrada de metais pesados no ambiente (Vetterlein \& Huttl, 1999) e a diminuição dos custos de transporte e de disposição (Rocha, 1998). Por outro lado, a aplicação de grandes quantidades de biossólido implica em riscos de produção excessiva de nitrato, que pode ser lixiviado e contaminar o lençol freático (Robinson et al., 2002). 


\subsubsection{Uso de biossólido em ecossistemas florestais}

É incontestável a importância social, econômica e ambiental dos plantios florestais para o país. Além de fornecerem lenha, carvão, madeira e celulose - negócios que movimentam US\$ 20 bilhões por ano, algo em torno de 5\% do Produto Interno Bruto nacional (Programa Nacional de Florestas - PNF, 2003), as florestas auxiliam na conservação de mananciais, do solo e da biodiversidade e finalmente na regulação do clima. Plantios florestais de rápido crescimento podem favorecer a diminuição de gases atmosféricos associados ao aquecimento global, processo incluído no chamado "Mecanismo de Desenvolvimento Limpo" (MDL) pelo Protocolo de Kyoto (Alonso, 2003).

O Brasil tem 6,4 milhões de florestas plantadas, sendo 4,8 milhões de hectares de pinus e eucaliptos (PNF, 2003). A Secretaria do Meio Ambiente de São Paulo, nos anos de 1999 e 2000, apontam que 3,1\% do território do Estado são de áreas reflorestadas - cerca de 770 mil hectares, sendo 611.516 hectares $(79,4 \%)$ com eucaliptos e 158.494 hectares (20,6\%) com pinus. Apesar destes valores, a cada 3 metros cúbicos de madeira consumida no Brasil, apenas um vem de florestas plantadas. A Sociedade Brasileira de Silvicultura estima que, para evitar o desmatamento em florestas nativas, a produção brasileira de florestas precisa aumentar em pelo menos $5 \%$ ao ano, valores que conflitam com a queda em 5\% das áreas florestadas com pinus e eucalipto na última década (Leite, 2003).

A crescente demanda por produtos florestais, a necessidade e perspectiva de ampliação das áreas destinadas ao plantio de florestas homogêneas e as baixas fertilidades dos sítios destinados a esta atividade obrigam a um aumento no consumo de fertilizantes neste setor, que pode ser minimizado com a reciclagem de resíduos sólidos, dentre eles o biossólido. A proximidade dos plantios de florestas comerciais das áreas urbanas endossa o grande potencial de uso deste resíduo, que é considerado pelo plano diretor da SABESP como uma das principais culturas potenciais para o uso do biossólido produzido na Região Metropolitana de São Paulo (Tsutyia, 2001). 
Algumas diferenças que favorecem a aplicação de biossólido em plantios florestais em relação a grande parte das culturas agrícolas são as aplicações espaçadas em longos períodos (Poggiani et al., 2000) e o fato de que os produtos obtidos nesses sistemas geralmente não são voltados ao consumo humano ou animal (Gonçalves et al., 2000b). Outros aspectos peculiares ao cultivo florestal é que geralmente este tipo de ecossistema favorece a minimização de perdas, devido as seguintes características: (i) há grande produção e distribuição de carbono orgânico em seus componentes, capazes de imobilizar grandes quantidades de nutrientes e metais pesados; (ii) boa infiltração do solo, minimizando os riscos de escoamento superficial; (iii) sistema radicular abundante e bem distribuído, que permite, em regiões tropicais, a absorção de nutrientes e metais pesados durante o ano todo, ou parte do ano, em regiões temperadas (Henry et al., 1994; Vaz \& Gonçalves, 2002). Diferentemente do uso de fertilizantes minerais, com a aplicação de biossólido é possível o suprimento das exigências nutricionais das árvores em diferentes épocas: em curto prazo, com respostas imediatas ao crescimento das plantas (Henry et al., 1994), e em longo prazo, pela contínua liberação de nutrientes para o solo e para o sistema radicular das árvores ao longo de vários anos, garantindo a nutrição das plantas e o aumento da produtividade (Zabowski \& Henry, 1994).

O uso de biossólido tem sido relatado na Europa, Austrália e América do Norte desde a década de setenta (Poggiani et al., 2000) em diversas espécies de interesse silvicultural (Dutch \& Wosltenholme, 1994). No Brasil, ainda são poucas e recentes as informações sobre a aplicação de biossólido em solos sob florestas (Andrade \& Mattiazzo, 2000; Faria, 2000; Guedes, 2000; Martins, 2002; Rocha, 2002; Vaz \& Gonçalves, 2002). As pesquisas de campo em condições tropicais, em especial no Brasil, são ainda limitadas em relação à diversidade de sítios florestais, formas de aplicação e tipos de biossólido utilizados, fatores que podem afetar decisivamente o comportamento destes resíduos quando aplicados no solo. 


\subsection{Efeito da aplicação de biossólido no solo}

\subsubsection{Fertilidade do solo}

O biossólido contém nutrientes essenciais às plantas, sendo sua composição variável de acordo com sua origem. Oliveira (2000) realizou uma aproximação da amplitude de variação da composição química dos biossólidos produzidos na região metropolitana de São Paulo, chegando aos seguintes valores: matéria orgânica $=313$ a $722 \mathrm{~g} \mathrm{~kg}^{-1} ; \mathrm{C}$-orgânico $=133$ a $229 \mathrm{~g} \mathrm{~kg}^{-1} ; \mathrm{N}$ total: 7,2 a 30,7 g $\mathrm{kg}^{-1} ; \mathrm{P}$ total $=0,5$ a $21,0 \mathrm{~g} \mathrm{~kg}^{-1} ; \mathrm{K}=0,8$ a 14,6 $\mathrm{g} \mathrm{kg}^{-1} ; \mathrm{Ca}=13,5$ a $162,7 \mathrm{~g} \mathrm{~kg}^{-1} ; \mathrm{Mg}=2,1$ a 27,3 $\mathrm{g} \mathrm{kg}^{-1}$; S-total =7,2 a 19,2 $\mathrm{g} \mathrm{kg}^{-1}$. O pH do biossólido pode variar de acordo com o tipo de condicionamento a que foi submetido, sendo alcalino ou próximo à neutralidade na presença ou ausência de cal.

Diversos trabalhos encontrados na literatura nacional e internacional confirmam a grande aptidão do biossólido para recondicionar as propriedades químicas, físicas e biológicas do solo, diminuindo sua densidade, aumentando a porosidade e a capacidade de retenção de água, alterando a quantidade de matéria orgânica, o pH, a CTC e as concentrações de macronutrientes, principalmente N, P e Ca, além de propiciar incremento de produtividade em diversas culturas (Santos, 1979; Phillips et al., 1986; Berton et al., 1989; Bevacqua \& Mellano, 1994; Dutch \& Wosltenholme, 1994; Melo et al., 1994; Oliveira et al., 1995; Silva et al., 1998; Skousen \& Klinger, 1998; Sort \& Alcañiz, 1999; Andreoli, 1999; Bramryd, 2001; Simonete, 2001; Rocha, 2002; Vaz \& Gonçalves, 2002; Oliveira et al., 2002; Trigueiro, 2002). Também é fonte energética para a microbiota do solo, importante agente nos diversos dos processos que ocorrem no solo (Metzger et al., 1987; Lambais \& Souza, 2000; Cardoso \& Fortes-Neto, 2000; Fortes-Neto, 2000; Carmo, 2001; Lopes, 2001; Zaman et al., 2002).

O efeito do biossólido sobre o $\mathrm{pH}$ dos solos é dependente do tipo de tratamento que o resíduo recebeu, taxa e frequência de aplicação do lodo e das diversas propriedades do solo (Oliveira et al., 2002). Biossólidos condicionados com cal possuem 
grande poder de neutralização, devido à sua alcalinidade intrínseca ( $\mathrm{pH}$ acima de 10). Este efeito pode ser observado nos experimentos conduzido por Barreto (1995), Anjos (1999), Oliveira et al. (2002), Vaz \& Gonçalves (2002) e Rocha (2002). No entanto, mesmo biossólidos alcalinos podem acidificar o solo em decorrência do excesso de $\mathrm{N}$ orgânico, que libera íons $\mathrm{H}^{+}$no processo de mineralização e nitrificação, contribuindo inclusive para a lixiviação de cátions (Harrison et al., 1996). Em biossólidos neutros (condicionados, por exemplo, com polieletrólitos), pode ocorrer um aumento inicial do pH do solo, ocasionado pelo poder de neutralização das reações envolvidas na degradação da carga orgânica do resíduo. No entanto, este efeito pode ser de curta duração e seguido por processos acidificantes (Boeira et al., 2002; Lopes, 2001).

Em relação a CTC, apesar dos constatados aumentos deste parâmetro pela aplicação do resíduo (Simeoni et al., 1984; Melo et al., 1994; Cavallaro et al., 1993; Silva, 1995; Simonete, 2001), a real contribuição do biossólido na capacidade de aumentar a CTC nos solos é questionada por Oliveira et al. (2002). Biossólidos condicionados com cal podem mascarar os efeitos na CTC pelo aumento do $\mathrm{pH}$ dos solos e pelas altas doses de Ca adicionadas (Simonete, 2001). Embora Simeoni et al. (1984) tenham atribuído o aumento da CTC ao incremento de C orgânico do solo, Oliveira et al. (2002) observaram que estes aumentos estão mais associados ao pH do solo que aos acréscimos de C orgânico. Importante salientar que estes últimos utilizaram biossólido condicionado com cal.

A despeito das vantagens supracitadas, uma das preocupações relevantes ao uso de biossólidos em culturas comerciais é o potencial desbalanço nutricional que este pode ocasionar ao solo, principalmente com relação às concentrações de $\mathrm{Ca}, \mathrm{Mg} \mathrm{e}$ K. Este desbalanço pode ser provocado pelo excesso de um ou mais nutrientes no biossólido e pela lixiviação de íons (Medalie et al., 1994; Bertoncini \& Mattiazzo, 1999; Anjos \& Mattiazzo, 2000 e Oliveira et al. 2002). Da Ros et al. (1993), em cultivos de milheto, aveia e ervilhaca, e Oliveira et al. (1995), na cultura do sorgo, observaram a necessidade de suplementação da fertilização do biossólido com $\mathrm{K}$, dada a baixa disponibilidade deste nutriente no resíduo (eliminação durante o processo de dehumificação do biossólido). Estes resultados, portanto, evidenciam a necessidade de 
um constante monitoramento de culturas com aplicação de biossólido, a fim de corrigir possíveis deficiências nutricionais (Zabowski \& Henry, 1994).

Em condições tropicais, estão sendo conduzidos experimentos na Estação Experimental de Itatinga (SP) numa área com reflorestamento de Eucalyptus grandis. O biossólido utilizado foi proveniente da ETE Barueri (SP), condicionado com cal e aplicado nas doses de 5, 10, 15, 20 e $40 \mathrm{t} \mathrm{ha}^{-1}$, na entrelinha de plantio sem incorporação. Nesta área, Guedes (2000), ao avaliar a ciclagem de nutrientes observou, até vinte meses pós-aplicação de $40 \mathrm{t} \mathrm{ha}^{-1}$ do biossólido (base seca), aumento da ciclagem biogeoquímica dos nutrientes, com aumento da quantidade de folhedo depositada pelas plantas em 136 e $40 \%$, respectivamente, comparados ao tratamento Controle e com aplicação de fertilizante mineral. Vaz \& Gonçalves (2002) observaram, aos seis meses pós-aplicação, a não alteração do $\mathrm{pH}$ e das concentrações de $\mathrm{P}, \mathrm{Mg}, \mathrm{Zn}, \mathrm{Cu}$ e $\mathrm{B}$ do solo $(0-30 \mathrm{~cm})$, e o aumento das concentrações de K, Ca e S. Aos treze meses, Rocha (2002) e Rocha \& Gonçalves $^{4}$ ainda observaram aumento do $\mathrm{pH}(0-5 \mathrm{~cm})$, maior disponibilidade de $\mathrm{P}$ e Ca (0-5, 5-10 e 10-20 cm), diminuição das concentrações de $\mathrm{S}$ e $\mathrm{K}$ e, aos 32 meses, aumento da concentração de S e K. Estes estudos avaliaram que, de modo geral, o biossólido condicionado com cal pode ser utilizado no povoamento de eucalipto, embora seja necessária a observação da disponibilidade do $\mathrm{P}$ por ocasião do plantio, suplementação de K ao longo do ciclo da cultura e acompanhamentos da evolução da fertilidade do solo e da nutrição vegetal ao longo dos próximos ciclos de cultivo (condução da brotação).

\section{Matéria orgânica no solo}

A matéria orgânica desempenha um importante e complexo papel na dinâmica dos solos, afetando suas características físicas, químicas e biológicas. Metzger \& Robert (1985) estudando a interação entre componentes orgânicos do lodo e partículas de argila em microscópio eletrônico de varredura, observaram que componentes

\footnotetext{
${ }^{4}$ ROCHA, G.N.; GONÇALVES, J.L.M. Monitoramento da fertilidade do solo, nutrição mineral e crescimento de um povoamento de Eucalyptus grandis fertilizado com biossólido. Revista Brasileira de Ciência do Solo, 2003. /Submetido/.
} 
orgânicos do lodo ligam as partículas de argila umas às outras, promovendo microagregação. Possíveis mecanismos de agregação incluem a formação de pontes por fibras orgânicas e envolvimento das partículas de argila por substâncias orgânicas. Metzger et al. (1987), estudando o efeito do biossólido na estabilidade estrutural dos solos, observaram aumento na população de fungos e bactérias após adição de lodo. A atividade destes fungos foi relacionada à cimentação por carboidratos exudados de fungos e a formação de redes de micélios em torno dos agregados, que atuaram como mecanismos de formação de agregados.

Jorge et al. (1991) mediante aplicação de 40 e 80 t ha ${ }^{-1}$ de biossólido, em uma única aplicação, e $80 \mathrm{t} \mathrm{ha}^{-1}$ em aplicações parceladas, com e sem calcário, constataram aumento da macroporosidade do solo com o primeiro procedimento (e calcário) e aumento da microporosidade com o segundo. Illera et al. (1999) observaram que, após 1 ano de aplicação do biossólido $\left(80 \mathrm{t} \mathrm{ha}^{-1}\right)$, houve uma leve melhoria da estrutura do solo, com pequena diminuição da densidade do solo e aumento na retenção de água do solo. Estes efeitos, segundo Metzger et al. (1987) podem ocorrer devido à união de colóides orgânicos aos minerais (ação cimentante), mas também por um simples efeito de mistura do resíduo ao solo, principalmente quando se processa a incorporação (Marciano, 1999). Marciano (1999) e Macedo (2002) ressalvam que a aplicação de biossólido pode alterar adversamente as propriedades físico-hídricas, como a diminuição na retenção de água à capacidade de campo, diminuição de macroporos e selamento superficial.

Lerch et al. (1992), avaliando a mineralização da matéria orgânica de solo condicionado com diversos tipos de biossólido, em condições de laboratório, explicaram a liberação do $\mathrm{CO}_{2}$ por uma cinética de primeira ordem, com taxas de mineralização do C variando de 2 a 34\%, sendo os maiores valores obtidos durante a primeira semana de incubação. Estes valores são próximos dos observados por Terry et al. (1979), que consideram 55 a $80 \%$ do C orgânico como recalcitrante. Em condições de campo, Oliveira et al. (2002) também estabeleceu uma cinética de degradação de primeira ordem para a degradação do $\mathrm{C}$, com decréscimos estimados em 65 e 73\%, 
respectivamente, para as doses de 66 e $99 \mathrm{t} \mathrm{ha}^{-1}$. No entanto, o autor ressalva que estas taxas podem estar superestimadas.

Fortes Neto (2000) dividiu o processo de degradação do biossólido aplicado em superfície em plantio florestal em quatro etapas: (1) queda na atividade microbiana, devido à adaptação às novas condições do solo, seguida por aumento desta atividade (2), pela resposta às frações lábeis de matéria orgânica e de nutrientes contidas neste biossólido. Nesta última fase, altas taxas de mineralização da matéria orgânica podem ocorrer. Posteriormente, há uma etapa de estabilidade da atividade microbiológica (3). Com o empobrecimento das quantidades de substrato energético e de nutrientes disponíveis, ocorre a última etapa (4), de declínio da atividade microbiológica, quando as concentrações de matéria orgânica do solo podem aumentar.

Aumento das concentrações do $\mathrm{C}$ orgânico no solo pela aplicação de diferentes doses de biossólido foi observada por Simonete (2001) em condições de laboratório, após 30 dias de incubação em vasos, por Logan et al. (1997) e por Oliveira et al. (2002) em solos sob cultivo agrícolas, com incorporação do resíduo. Em solos sob florestas, Vaz \& Gonçalves (2002), Rocha (2002) e Rocha \& Gonçalves (op. cit., p.13) observaram diminuição nas concentrações de matéria orgânica aos seis meses pósaplicação do biossólido, nos tratamentos que receberam 10, 20 e $40 \mathrm{t} \mathrm{ha}^{-1}$ de biossólido mais suplementação de K. Este efeito também foi observado por Lerch et al. (1992), e pode ter sido ocasionado pela mineralização secundária da matéria orgânica (efeito “priming" 5 "). Treze meses pós-aplicação do biossólido, na camada 0-3 cm, as concentrações de carbono orgânico nos tratamentos 20 e $40 \mathrm{t} \mathrm{ha}^{-1}+\mathrm{K}$ foram semelhantes aos observados na testemunha e, aos 32 meses, não houve diferenças entre tratamentos. De acordo com os autores, a possível contribuição para o aumento da matéria orgânica do solo, na camada 0-5 cm, seria o aporte de ácidos e outros resíduos orgânicos, oriundos da reciclagem de biomassa microbiana e raízes finas.

\footnotetext{
5 A adição de matéria orgânica ao solo pode promover a intensificação da atividade da biomassa microbiana, que utiliza, para a obtenção de energia, fontes de $\mathrm{C}$ já existentes no solo (Soil Science Society of America, 1997; Kuzyakov et al., 2000). A intensidade deste efeito é condicionada aos diferentes atributos do solo, como textura, estrutura e porosidade, e características da matéria orgânica natural do solo, como a sua quantidade, qualidade e localização em poros e agregados.
} 
Aplicações de biossólidos podem não afetar em curto prazo a quantidade de C total no solo (Oliveira, 2000), mas interferir qualitativamente nos seus compostos derivados. Evidências de alterações na quantidade e qualidade das substâncias húmicas do solo pela adição de biossólido foram observadas por Canellas et al. (2001). Os autores, adicionando biossólido com pH inicial 7,0 em um Latossolo Vermelho Amarelo textura argilosa e um Argissolo Vermelho Amarelo textura média, em vasos, observaram alterações na distribuição das frações humificadas das amostras de solo com adição de biossólido, com aumento do conteúdo de ácidos fúlvicos, implicando na diminuição das relações ácidos húmicos/ácidos fúlvicos e na qualidade do humus do solo. Embora os autores não tenham observado mudanças quantitativas no conteúdo dos ácidos húmicos, estes sofreram modificações nas suas características estruturais nos dois solos, principalmente com a diminuição do conteúdo de $\mathrm{C}$ em longas cadeias alquílicas e aumento no conteúdo de $\mathrm{C}$ presente em polissacarídeos incorporados às estruturas dos ácidos húmicos. Com o uso de Ressonância Magnética Nuclear, os autores puderam observar, no Argissolo Vermelho Amarelo, decréscimo de $\mathrm{C}$ aromático e acréscimo de $\mathrm{C}$ ligado a polissacarídeos, produzidos pela atividade biológica e incorporados nas estruturas dos ácidos húmicos, juntamente com a degradação dos compostos mais condensados (alquílicos).

Pôde-se observar que o efeito do biossólido na matéria orgânica no solo é variável em função de características do sítio e do resíduo utilizado. Especialmente em sistemas degradados, é importante se conhecer qual o aporte de matéria orgânica necessário para o estabelecimento das funções do solo de forma direta e/ou indireta, pelo uso de doses suficientes para o aumento da cobertura vegetal, o maior acúmulo de serapilheira e a diminuição das perdas pela erosão do vento e da água, evitando-se desta forma a aplicação de doses excessivas (Vetterlein et al., 1999).

\subsubsection{Riscos de danos ambientais}

Apesar do grande potencial de uso, não devem ser menosprezados os possíveis impactos ambientais vinculados à utilização de biossólido. Alterações 
observadas em países de clima temperado podem ter outras amplitudes em condições edáficas e climáticas de ambiente tropical (Sigolo, 1998; Cornu et al., 2001).

Problemas associados com o biossólido são a movimentação (lixiviação e escoamento superficial) de nutrientes em excesso para cursos d'água, presença de metais pesados, substâncias orgânicas tóxicas e patógenos. Estas substâncias são indesejáveis do ponto de vista ambiental, pois, em contato com o homem e/ou com a fauna e a flora, podem causar doenças e contaminações diversas.

A aplicação de grandes quantidades de resíduos orgânicos pode contaminar águas superficiais e subterrâneas com a transferência de bactérias entéricas a animais e humanos (Entry \& Farmer, 2001). Os mesmos autores, avaliando a ocorrência de coliformes fecais em aqüíferos basálticos e sedimentares em regiões irrigadas, observaram maior fluxo e ocorrência de coliformes nos aqüíferos basálticos que nos sedimentares, indicando maior poder de filtragem da água deste último. Concluíram também que estes aqüíferos não estão seguros da contaminação por bactérias, colocando em risco o consumo humano destas águas. Com a aplicação do biossólido em superfície, embora grande parte dos patógenos presentes no biossólido seja eliminada pela ação da luz solar, em especial os raios ultravioletas, é necessário se determinar a sobrevivência desses patógenos em solos condicionados com biossólido, incluindo vírus e ovos de helmintos (Sierra et al., 2001).

O P também tem sido identificado como um dos principais fatores de eutroficação de cursos d'água (Maguire et al., 2000). Apesar de alguns estudos indicarem a não ocorrência de lixiviação excessiva de P (Mitchell et al., 2000; Maguire et al., 2000; Shepherd \& Withers, 2001), McDowell \& Sharpley (2001) alertam que a aplicação de lodos para o adequado suprimento de $\mathrm{N}$ às plantas pode resultar na saturação dos sítios de adsorção, no maior potencial de dessorção de $\mathrm{P}$ para a solução do solo e, como conseqüência, em perdas por lixiviação. Em florestas, o excesso de P nos solos pode ainda provocar diminuição da produtividade, por favorecer o maior crescimento de plantas invasoras e, conseqüentemente, aumentar a competição entre esta e a cultura por água e nutrientes (Novais \& Smyth, 1999). No entanto, o P é um elemento crítico à nutrição e ao crescimento do eucalipto, principalmente em sua fase inicial de 
crescimento (Novais et al., 1986 e 1990; Furtini Neto et al., 1998). O estudo de estratégias de aplicação do biossólido pode orientar alternativas de manejo da fertilidade de $\mathrm{P}$ no solo que associe a produtividade da cultura à economia de insumos, sem danos adversos ao meio ambiente.

Em relação aos metais pesados, pesquisas recentes em solos sob florestas indicam que, após 360 dias de aplicação do biossólido, não há movimentação dos metais $\mathrm{Cd}, \mathrm{Cr}, \mathrm{Cu}$ e Ni no solo, até a profundidade de $90 \mathrm{~cm}$ (Andrade \& Mattiazzo, 2000). Os autores observaram que apenas o $\mathrm{Zn}$ foi acumulado na camada $30-60 \mathrm{~cm}$, indicando movimento deste elemento no perfil do solo. Nos últimos 20 anos, a tecnologia de tratamento do lodo promoveu melhorias significativas na remoção de toxinas e contaminantes deste resíduo (Reuter, 2000). No entanto é importante o monitoramento destes fatores nos diferentes ecossistemas em que o biossólido é aplicado, principalmente com o uso de resíduos em doses excessivas e, ou com grandes quantidades de metais pesados.

\subsubsection{Dinâmica do $\mathrm{N}$}

A saturação de $\mathrm{N}$ no solo é favorecida por diversas atividades antropogênicas, como excesso no uso de fertilizantes, de resíduos orgânicos e emissão de gases do efeito estufa ${ }^{6}$. Mesmo em solos de ecossistemas florestais deficientes em $\mathrm{N} \mathrm{e}$ com baixo potencial de nitrificação, a saturação de $\mathrm{N}$ pode eventualmente ser atingida, se forem utilizadas fontes nitrogenadas em excesso (Van Miegroet \& Johnson, 1993).

Biossólidos apresentam grandes quantidades de N em sua composição, concentradas principalmente na forma orgânica e, portanto, não prontamente disponíveis às plantas (Mamo et al., 1999). Estes materiais apresentam, em média, 7,2 a $30 \mathrm{~g} \mathrm{~kg}^{-1} \mathrm{de}$ $\mathrm{N}$ total (Reuter, 2000), sendo que aproximadamente 90\% está na forma orgânica. Uma

\footnotetext{
${ }^{6} \mathrm{O}$ aumento da temperatura global pode estimular a mineralização e a maior disponibilidade de $\mathrm{N}$ (Van Miegroet \& Johnson, 1993).
} 
vez mineralizado, pode ser convertido a $\mathrm{NO}_{3}^{-}$e lixiviado, contaminando águas superficiais e subterrâneas (Gerke et al., 1999).

$\mathrm{O}$ consumo de águas com teores de $\mathrm{NO}_{3}{ }^{-}$acima dos limites recomendados pela Organização Mundial de Saúde (OMS) podem ocasionar problemas de saúde em animais e em seres humanos, especialmente em crianças menores que três anos de idade (metahemoglobinemia ou "síndrome do bebê azul") (National Research Council, 1972). Por estes motivos, um dos critérios que limita a aplicação do biossólido é o nível de $\mathrm{N}$ presente no material (Companhia de Tecnologia e Saneamento Ambiental - CETESB, 1999).

A relação custo/benefício da aplicação de grandes quantidades de biossólido na qualidade do lençol freático e nas proximidades de cursos d'água foi discutida por Sopper (1992) e Pierce et al. (1998). Por exemplo, o estado da Pensilvânia proíbe o uso de biossólido em bacias hidrográficas que suprem água potável às comunidades vizinhas. No entanto, o uso deste material na estabilização de áreas drasticamente degradadas freqüentemente favorece a qualidade dos cursos d'água próximos ao local de aplicação, por beneficiar o ecossistema como um todo (Sopper, 1992).

Oliveira \& Mattiazzo (1996), em condições de laboratório (tubos de percolação), observaram que a maior parte da carga orgânica adicionada via biossólido, em amostras de Neossolo Quartzarênico e Latossolo Vermelho distrófico, foi degradada até os 63 dias de incubação, contribuindo desta forma para o aumento das formas nitrogenadas potencialmente lixiviáveis nos primeiros dois meses de aplicação. Riscos de contaminação do lençol freático por períodos mais extensos foram observados por Sopper \& Kerr ${ }^{7}$, citados por Sopper (1992) e por Pietz et al. (1989b). Em uma área de mineração recuperada com a aplicação de biossólido na Pensilvânia, estes autores observaram que a concentração de $\mathrm{NO}_{3}{ }^{-}$na água coletada de poços de monitoramento do lençol freático esteve dentro dos limites legais somente após cinco anos de aplicação do material. Em estudo com rejeitos de carvão, Pietz et al. (1989b) avaliando o efeito da 
aplicação de biossólido $\left(542 \mathrm{t} \mathrm{ha}^{-1}\right)$, calcário $\left(89,6 \mathrm{t} \mathrm{ha}^{-1}\right)$ e gesso $\left(112 \mathrm{t} \mathrm{ha} \mathrm{a}^{-1}\right)$, em várias combinações, na qualidade da água percolada à profundidade de 1 metro, observaram que as concentrações médias anuais de $\mathrm{NH}_{4}{ }^{+}$e $\mathrm{NO}_{3}{ }^{-}+\mathrm{NO}_{2}{ }^{-}$variaram de 0,8 a 225 e 0 a $278 \mathrm{mg} \mathrm{L}^{-1}$, respectivamente, sendo os maiores valores obtidos no tratamento com biossólido nos primeiros três anos pós-aplicação, seguido de declínio a níveis próximos ao limite tolerável pela legislação após cinco anos.

Em sistemas agrícolas, é usual assumir que os processos que governam a lixiviação de $\mathrm{N}$ ocorrem em curto prazo, enquanto que outros contaminantes, como os metais pesados, limitam a taxa de aplicação em longo prazo. No entanto, para florestas esta afirmação pode não ser apropriada, pois a ciclagem de nutrientes é muito diferente dos sistemas agrícolas convencionais, pela manutenção da serapilheira, e pela menor freqüência de colheitas (Crohn \& Haith, 1994). O grande estoque orgânico presente na serapilheira apresenta tipicamente alta relação $\mathrm{C} / \mathrm{N}$, podendo imobilizar significativas quantidades de N. A partir deste pressuposto, alguns trabalhos indicam que a lixiviação de $\mathrm{NO}_{3}{ }^{-}$pode ser atenuada pela aplicação de biossólido em superfície, onde a temperatura e a umidade não são favoráveis a nitrificação (Sierra el al., 2001).

Crohn \& Haith (1994 e 1995) e Luxmoore et al. (1999), utilizando modelos para investigar o impacto em longo prazo da aplicação de biossólido na qualidade das águas subterrâneas (tomando como referência o N), em uma floresta de carvalho nos EUA, concluíram que são possíveis de serem aplicadas altas doses se observados grandes intervalos de tempo e, além disso, se for permitido ao ecossistema a imobilização de N no solo e na serapilheira acumulada. No Brasil, Andrade \& Mattiazzo (2000), em um plantio de E. grandis com uso de diferentes doses de biossólido aplicados em superfície, não observaram alterações no teor de $\mathrm{N}$ total e $\mathrm{N}^{-\mathrm{NO}_{3}}{ }^{-}$no solo até os 90 cm em um ano de estudo.

As observações supracitadas podem não ser válidas para todos os plantios florestais, pois a dinâmica do $\mathrm{N}$ oriundo da aplicação de biossólido é dependente da

\footnotetext{
${ }^{7}$ SOPPER, W.E.; KERR, S.N. Revegetating strip-mined land with municipal sewage sludge. Project
} 
combinação de diversos outros fatores, como a qualidade do biossólido, sua mineralização (dependente também da temperatura, pH e umidade) (Terry et al., 1981), da quantidade e da qualidade da serapilheira sobre o solo (Bramryd, 2001) e ainda das características da cobertura vegetal, como a idade da cultura, espécie cultivada e aspectos de manejo (controle de ervas invasoras, desrama, desbaste, etc.) - (Mitchell et al., 2000).

Mitchell et al. (2000) assinalam três fases de cultivo como as mais críticas para perdas de $\mathrm{N}$ e P. A primeira é por ocasião do plantio das mudas, com riscos de perdas via escoamento superficial. Esta fase é mais crítica em solo nu, sendo minimizado pela presença de resíduos vegetais na superfície do solo (como no cultivo mínimo). A segunda fase está relacionada às maiores taxas de mineralização do $\mathrm{N}$ e conseqüente risco de lixiviação deste elemento. A terceira fase é após o corte raso, quando a absorção de $\mathrm{N}$ pelas plantas é diminuida bruscamente, podendo também ocorrer sua lixiviação. Henry et al. (1994), aplicando $47 \mathrm{tha}^{-1}$ de biossólido (base seca) em solo sob floresta em diferentes épocas de cultivo, observaram que os maiores riscos de lixiviação de $\mathrm{NO}_{3}{ }^{-}$ ocorreram na seguinte ordem: florestas maduras, áreas recentemente cortadas e florestas jovens (perdas de 57, 25 e $10 \mathrm{mg} \mathrm{L}^{-1}$ de $\mathrm{NO}_{3}^{-}$, respectivamente, a $50 \mathrm{~cm}$ de profundidade). Segundo os autores, a lixiviação ocorre em grande parte durante o primeiro ano pós-aplicação do biossólido, diminuindo drasticamente nos anos seguintes e alcançando níveis adequados apenas no terceiro ano pós-aplicação.

Em uma floresta de carvalho nos EUA, Aschmann et al. (1992), avaliando a solução de um solo submetidos a doses crescentes de biossólido anaeróbio (0, 3, 6 e 12 $\mathrm{t} \mathrm{ha}^{-1}$ base seca, equivalentes a $0,200,400$ e $800 \mathrm{~kg} \mathrm{ha}^{-1} \mathrm{de} \mathrm{N}$ ) a $0,8 \mathrm{~m}$ de profundidade e por 18 meses, observaram, aos sete meses pós-aplicação do biossólido e na dose $3 \mathrm{t} \mathrm{ha}^{-1}$, picos de concentração de $\mathrm{N}_{-} \mathrm{NO}_{3}{ }^{-}$de $30 \mathrm{mg} \mathrm{L}^{-1}$, diminuindo rapidamente para os níveis do tratamento controle. Nos tratamentos subseqüentes, a concentração média de $\mathrm{N}_{-} \mathrm{NO}_{3}{ }^{-}$ foi em torno de $40 \mathrm{mg} \mathrm{L}^{-1}$ durante um ano pós-aplicação do material. Foram observadas

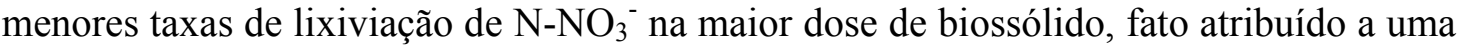


possível inibição no processo de mineralização ou nitrificação, devido à salinidade ou a maiores concentrações de substâncias tóxicas. Apesar dos valores encontrados, os autores consideram que a aplicação de até $3 \mathrm{t} \mathrm{ha}^{-1}$ de biossólido não apresenta riscos de contaminação do lençol freático.

Medalie et al. (1994), em experimento similar, comparando parcelas densamente vegetadas com áreas onde a vegetação foi suprimida, ambas submetidas a doses crescentes de biossólido aeróbio $\left(0,3,3,6,9\right.$ e 14,5 tha ${ }^{-1}$, base seca, equivalentes a 0, 199, 396 e $740 \mathrm{~kg} \mathrm{ha}^{-1}$ de N), observaram, a 1 e $4 \mathrm{~m}$ de profundidade, na solução do solo não vegetado e sem biossólido, valores de nitrato menores que $3 \mathrm{mg} \mathrm{L}^{-1}$, ao passo que nos tratamentos sem vegetação e com 6,9 e 14,5 t ha ${ }^{-1}$ de biossólido, constataram picos de concentração de 13 e $32 \mathrm{mg} \mathrm{L}^{-1}$ de nitrato, respectivamente. As parcelas vegetadas não apresentaram grandes concentrações de nitrato na solução do solo, durante as épocas avaliadas. Os dados evidenciaram não apenas a importância da vegetação arbórea, como também do bom manejo da vegetação herbácea na manutenção do N no ecossistema.

\subsection{Adequação das quantidades e das épocas de aplicação de biossólido em plantios florestais}

Mecanismos legais de proteção à saúde pública e ao meio ambiente são passíveis de aprimoramento a partir do desenvolvimento científico, tecnológico, aspectos econômicos, sociais e culturais (Hespanhol, 2001). A legislação vigente para o estado de São Paulo foi baseada na legislação americana, denominada EPA CFR 40 Part 503 ((Estados Unidos, 1997) e estabelecida em condições ambientais distintas das condições tropicais. No entanto, a partir da variabilidade ambiental, do tipo de biossólido e de condições de aplicação, existe a necessidade de avaliação e de sugestões, por parte de pesquisadores, institutos de pesquisas, empresas, técnicos e agricultores, para o endosso ou o aprimoramento da norma vigente (Carvalho \& Carvalho, 2001).

Diversos experimentos têm sido conduzidos a fim de avaliar as doses e épocas adequadas de aplicação do biossólido, que incrementem a produtividade da 
cultura sem danos ao meio ambiente. Em plantios florestais, pode-se encontrar na literatura disponível, em caráter experimental, duas filosofias de aplicação de biossólido (Henry et al., 1994): (1) aplicações anuais, destinadas somente a fornecer as quantidades de nutrientes requeridas anualmente pelas plantas e (2) aplicações de grandes quantidades de biossólido, seguidas por vários anos sem nova aplicação.

De acordo com Oliveira et al. (2001), o N é o fator mais limitante do que os metais pesados na definição das doses de aplicação de biossólido. Em observação a este risco, Robinson et al. (2002), ao constatarem que a aplicação de doses superiores a $30 \mathrm{t} \mathrm{ha}^{-1}$ de biossólido tem o potencial de contaminar cursos d'água no primeiro ano pósaplicação do biossólido, sugeriram o uso de menores quantidades em florestas. Luxmoore et al. (1999), comparando a eficiência de diferentes taxas de aplicação de biossólido (doses únicas de 0,5,10,20 e $40 \mathrm{t} \mathrm{ha}^{-1}$ e múltiplas aplicações de 5 e $10 \mathrm{t} \mathrm{ha}^{-1}$, em intervalos de três anos), no crescimento e na mineralização de $\mathrm{N}$, em duas plantações de coníferas e uma de carvalho, sugeriram que a aplicação de doses de biossólido menores que $8,5 \mathrm{tha}^{-1}\left(400 \mathrm{~kg} \mathrm{ha}^{-1} \mathrm{~N}\right)$, na fase de crescimento da floresta e em intervalos de três anos, tem pouco risco de contaminação de águas subsuperficiais por N. Chron (1995), a partir de modelos matemáticos, avaliou que as doses mais adequadas, em aplicações com intervalo de três a quatro anos, está na ordem de 3-4 $\mathrm{t} \mathrm{ha}^{-1}$ de biossólido.

Em condições tropicais, os experimentos conduzidos por Guedes (2000), Vaz \& Gonçalves (2002) e Rocha \& Gonçalves (op. cit., p.13), em plantio de E. grandis, tiveram como proposta a aplicação de dose única de biossólido após o plantio das mudas, ou neste período e na condução da rebrota, isto é, a cada 7 ou 14 anos. Resultados recentes indicam que o maior crescimento das árvores, aos 17 meses de plantio, ocorre no tratamento com $10 \mathrm{t} \mathrm{ha}^{-1}$ de biossólido mais suplementação de $\mathrm{P}$ (Vaz \& Gonçalves, 2002). Na mesma área, aos 32 meses de plantio, as doses de biossólido com tendência à maior produtividade de madeira foram de $10 \mathrm{t} \mathrm{ha}^{-1}$ com adição de $\mathrm{K} \mathrm{e} \mathrm{P}$ e $40 \mathrm{t} \mathrm{ha}^{-1}$ com adição de $\mathrm{K}$ (Rocha, 2002). As duas doses não apresentaram riscos de contaminação com metais pesados e nitrato no período avaliado, de acordo com Andrade \& Mattiazzo (2000). No entanto os dados são referentes apenas aos primeiros anos de cultivo, não podendo ser tomados como conclusivos. Considerando-se o efeito residual 
do biossólido e a economia de aplicação do material, Rocha (2002) sugerem que a maior dose utilizada poderia ter maior aplicabilidade no ecossistema em estudo. No entanto, são fundamentais estudos complementares que permitam a elaboração de diretrizes de manejo do biossólido nestes ecossistemas, baseadas na limitação do número de aplicações sucessivas, possíveis períodos de cessamento necessários ao retorno do solo às suas condições originais, quanto aos teores de $\mathrm{N}$ (Oliveira et al., 2001), sem desconsiderar que o uso de grandes quantidades de biossólido pode não compensar seus possíveis efeitos deletérios (Vetterlein \& Huttl, 1999). 


\section{MATERIAL E MÉTODOS}

\subsection{Caracterização da região e da área de estudo}

A cidade de Salto de Pirapora, distante $28 \mathrm{~km}$ da cidade de Sorocaba, e $130 \mathrm{~km}$ da cidade de São Paulo, tem as seguintes coordenadas geográficas: 23 $39^{\circ} \mathrm{S}$ e $47^{\circ} 34^{\prime}$ W (Figura 1). A região tem clima do tipo Cwa, com precipitação média anual de $1328 \mathrm{~mm}$, temperatura média anual variando de 15,1 a $22,8{ }^{\circ} \mathrm{C}$, com temperaturas média máxima de $22,8{ }^{\circ} \mathrm{C}$ e mínima de $15,1{ }^{\circ} \mathrm{C}$ (Figura 2). O período de estiagem é menor do que três meses. O relevo, modelado em torno de $630 \mathrm{~m}$ de altitude, é de colina suave, referente à depressão periférica, com maiores altitudes nas regiões limítrofes, relacionadas ao planalto cristalino. A área experimental localizou-se num planalto sedimentar, onde afloram sedimentos da Formação Itararé. São constituídos por arenitos de granulação heterogênea, mineralogicamente imaturos, passando a arenitos feldspáticos e arcósicos, diamectitos, clastos de diversas litologias e sedimentos rítmicos, em que se alternam em nítida estratificação plano-paralela, arenitos finos, siltitos cinza claro e folhelhos cinza mais escuros, referidos geralmente como varvitos (Instituto de Pesquisas Tecnológicas do Estado de São Paulo - IPT, 1981). A vegetação natural da região é a Floresta Estacional Semidecídua. O solo do local de estudo é o Latossolo Vermelho-Amarelo Distrófico (Empresa Brasileira de Pesquisa Agropecuária - EMBRAPA, 1999).

O experimento foi conduzido na Fazenda São Paulo, pertencente a EUCATEX S/A (Figura 1). A fazenda possui área total de 781,13 ha, estando 415,98 ha ocupados por plantio de eucalipto. 


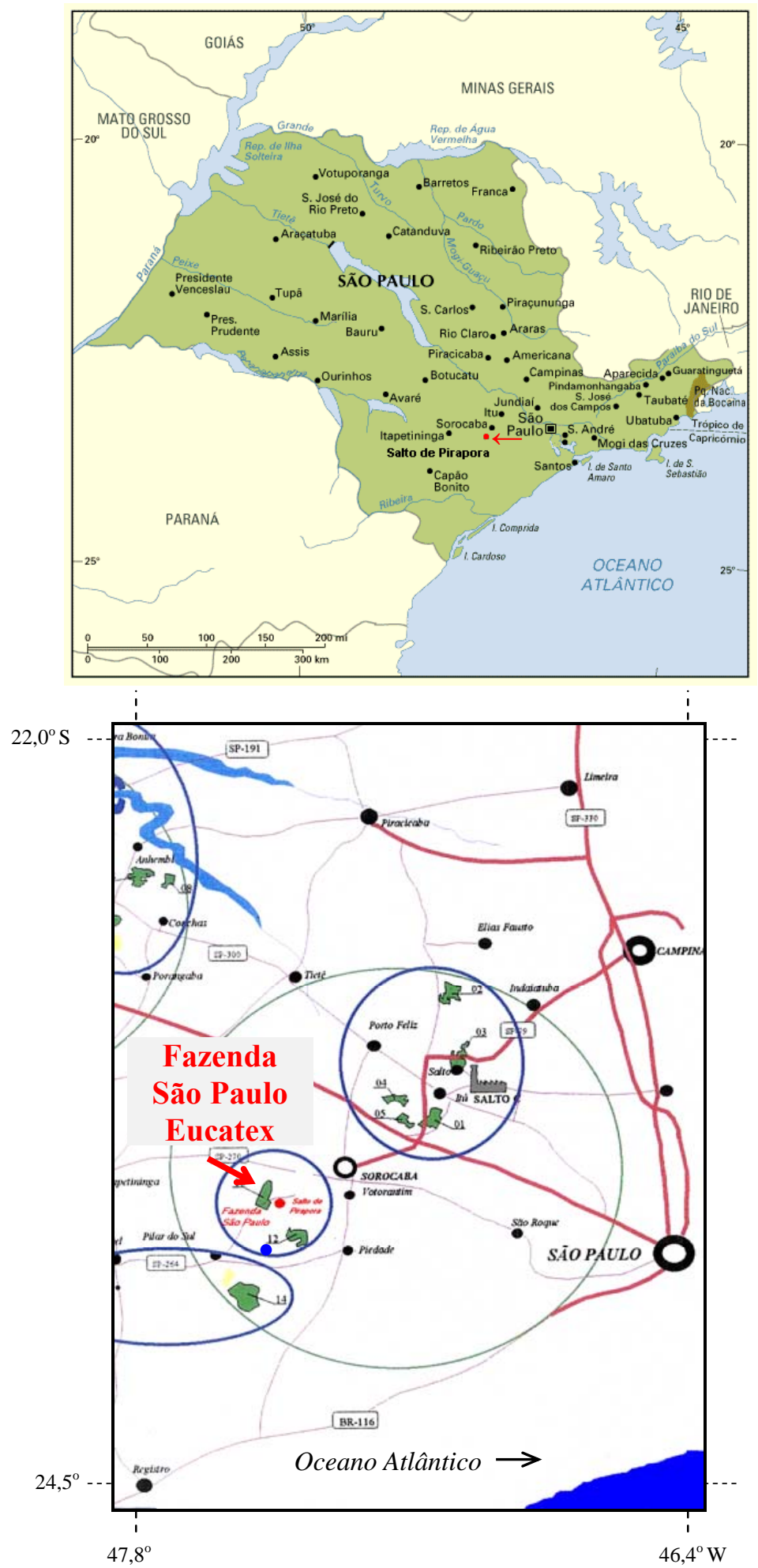

Figura 1- Localização do Município de Salto de Pirapora (SP) e a Fazenda São Paulo, onde o experimento foi instalado 


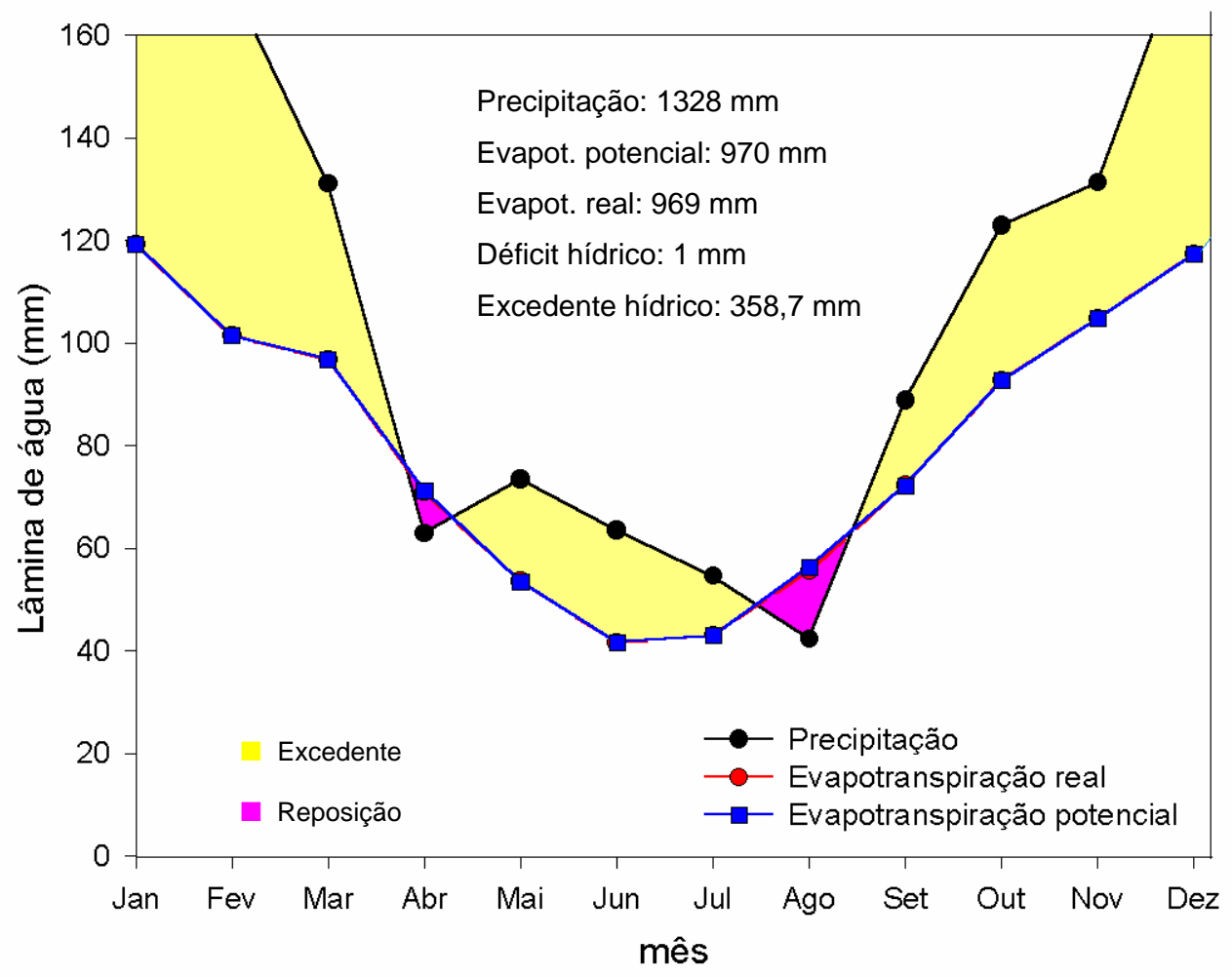

Figura 2- Balanço hídrico da cidade de Salto de Pirapora (SP), segundo Thornthwaite \& Matter (1955) (média de 29 anos) 


\subsection{Características do biossólido}

O biossólido usado no experimento foi produzido na Estação de Tratamento de Esgoto de Barueri, da Companhia de Saneamento Básico de São Paulo (SABESP). O sistema de tratamento é o de lodos ativados convencional, que consiste em uma fase de digestão aeróbica (fase de decantação) seguida de anaeróbica (fase final do digestor). A desidratação do material foi realizada com a adição de polímeros em substituição à cal extinta, processo que diminui substancialmente o $\mathrm{pH}$ do biossólido, em comparação ao segundo processo citado (Tabela 1). A classificação do biossólido é "tipo B", segundo critério fixado pela Companhia de Tecnologia e Saneamento Ambiental CETESB (1999), ou seja, a concentração de coliformes fecais é inferior a 2.000.000 NMP (número mais provável) por grama de sólidos totais.

Amostras do biossólido foram coletadas em sete pontos distintos do volume depositado na Fazenda, perfazendo uma amostra composta, no dia da chegada deste ao local do experimento (11 de agosto de 2001). A amostra foi posteriormente enviada ao Laboratório de Análise de Solo e Planta do Instituto Agronômico de Campinas, para ser submetida às análises químicas (Tabela 1).

Tabela 1. Composição do biossólido tipo B produzido pela Estação de Tratamento de Esgoto de Barueri, SABESP/SP (agosto 2001) ${ }^{(1)}$

\begin{tabular}{|c|c|c|c|}
\hline Elemento $^{(2)}$ & Concentração & Elemento $^{(2)}$ & Concentração \\
\hline C org. $\left(\mathrm{g} \mathrm{kg}^{-1}\right)$ & 373,5 & $\mathrm{Al}\left(\mathrm{mg} \mathrm{kg}^{-1}\right)$ & 18.256 \\
\hline N Kjeldahl $\left(\mathrm{g} \mathrm{kg}^{-1}\right)$ & 40,7 & As $\left(\mathrm{mg} \mathrm{kg}^{-1}\right)$ & $<0,01$ \\
\hline $\mathrm{N}-\mathrm{NH}_{4}{ }^{+}{ }^{(3)}\left(\mathrm{mg} \mathrm{kg}^{-1}\right)$ & 1.913 & $\mathrm{Cd}\left(\mathrm{mg} \mathrm{kg}^{-1}\right)$ & 10,9 \\
\hline $\mathrm{N}-\mathrm{NO}_{3}^{-}-\mathrm{NO}_{2}^{-}{ }^{-(3)}\left(\mathrm{mg} \mathrm{kg}^{-1}\right)$ & 32,2 & $\mathrm{~Pb}\left(\mathrm{mg} \mathrm{kg}^{-1}\right)$ & 206,1 \\
\hline $\mathrm{P}\left(\mathrm{g} \mathrm{kg}^{-1}\right)$ & 25,4 & $\mathrm{Cu}\left(\mathrm{mg} \mathrm{kg}^{-1}\right)$ & 879,5 \\
\hline $\mathrm{K}\left(\mathrm{g} \mathrm{kg}^{-1}\right)$ & 1,0 & Cr total $\left(\mathrm{mg} \mathrm{kg}^{-1}\right)$ & 791,8 \\
\hline $\mathrm{Ca}\left(\mathrm{g} \mathrm{kg}^{-1}\right)$ & 25,3 & $\mathrm{Hg}\left(\mathrm{mg} \mathrm{kg}^{-1}\right)$ & $<0,01$ \\
\hline $\operatorname{Mg}\left(\mathrm{g} \mathrm{kg}^{-1}\right)$ & 4,3 & $\mathrm{Mo}\left(\mathrm{mg} \mathrm{kg}^{-1}\right)$ & $<0,01$ \\
\hline $\mathrm{Na}\left(\mathrm{mg} \mathrm{kg}^{-1}\right)$ & 0,25 & $\mathrm{Ni}\left(\mathrm{mg} \mathrm{kg}^{-1}\right)$ & 395,1 \\
\hline $\mathrm{S}\left(\mathrm{g} \mathrm{kg}^{-1}\right)$ & 13,6 & $\mathrm{Se}\left(\mathrm{mg} \mathrm{kg}^{-1}\right)$ & $<0,01$ \\
\hline $\operatorname{Mn}\left(\mathrm{mg} \mathrm{kg}^{-1}\right)$ & 266,2 & $\mathrm{Zn}\left(\mathrm{mg} \mathrm{kg}^{-1}\right)$ & 2.827 \\
\hline $\mathrm{Fe}\left(\mathrm{mg} \mathrm{kg}^{-1}\right)$ & 32.017 & $\mathrm{~B}\left(\mathrm{mg} \mathrm{kg}^{-1}\right)$ & 9,5 \\
\hline \multicolumn{4}{|l|}{ Outros Atributos } \\
\hline $\mathrm{pH}$ & 8,7 & & \\
\hline Umidade & 72,3 & & \\
\hline Sólidos Voláteis & 60 & & \\
\hline
\end{tabular}




\subsection{Instalação do experimento, tratamentos e delineamento experimental}

O experimento foi instalado em um talhão de 15,1 ha, que apresentava um povoamento homogêneo de Eucalyptus saligna de 27 anos, no espaçamento $3 \mathrm{~m} \mathrm{x} \mathrm{1,5}$ m. Este povoamento foi colhido (corte raso) em 1998. Em seguida, conduziu-se a brotação até maio de 2001, quando foi feita nova colheita e a reforma florestal para a instalação do experimento.

Dois meses após a colheita de madeira, as plantas invasoras foram controladas com glifosato, aplicado em área total. Os tocos remanescentes foram rebaixados até a superfície do solo com uso de um desbastador rotativo de tocos. Os galhos foram triturados com uso de uma "trincha" (triturador de galhada).

A área experimental foi dividida em duas sub-áreas (Figura 3), uma preparada no sistema de cultivo mínimo do solo $\left(9.216 \mathrm{~m}^{2}\right)$ (solo não-degradado), e a outra onde foi simulada a degradação do solo, com a remoção de parte do horizonte A (camada 0-20 cm) (solo degradado). Nesta área, previamente, os tocos foram rebaixados até $20 \mathrm{~cm}$ abaixo da superfície do solo e parte do solo foi removido com uma motoniveladora (Figura 4a e 4b). Entre estas duas sub-áreas foi mantida uma faixa intacta de solo (bordadura), com $10 \mathrm{~m}$ de largura (Figura 3).

O delineamento experimental utilizado foi o de blocos ao acaso, com nove tratamentos e quatro repetições. Seis tratamentos foram estabelecidos na área com solo não-degradado e três tratamentos foram estabelecidos no solo degradado. Tratamentos no solo não-degradado: (1) Controle, (2) Fertilização Mineral, (3) $10 \mathrm{t} \mathrm{ha}^{-1}$, (4) $20 \mathrm{t} \mathrm{ha}^{-1}$, (5) $40 \mathrm{t} \mathrm{ha}^{-1} \mathrm{e}$ (6) $10 \mathrm{t} \mathrm{ha}^{-1}$ de biossólido. Tratamento no solo degradado: (7) Controle, (8) 20 e (9) $40 \mathrm{t} \mathrm{ha}^{-1}$ de biossólido. Todos os tratamentos, com exceção do sexto, receberam suplementação de P e K. As quantidades de biossólido são dadas em base seca. Essas doses de biossólido foram estabelecidas com base nos estudos desenvolvidos por Vaz \& Gonçalves (2002), Rocha (2002), Rocha \& Gonçalves ${ }^{8}$ e

\footnotetext{
${ }^{8}$ ROCHA, G.N.; GONÇALVES, J.L.M. Monitoramento da fertilidade do solo, nutrição mineral e crescimento de um povoamento de Eucalyptus grandis fertilizado com biossólido. Revista Brasileira de Ciência do Solo, 2003. /Submetido/.
} 
Andrade \& Mattiazzo (1999). A suplementação de P no plantio (adubação de arranque) foi realizada em quantidade suficiente para a obtenção de produtividade máxima (Gonçalves et al., 1996). Isto é necessário porque a exigência de $\mathrm{P}$ pelo eucalipto é muito elevada na fase inicial de crescimento (Barros et al., 1986, 1990) e, conforme constatações de Vaz \& Gonçalves (2002) e Rocha (2002), a mineralização de P do biossólido é lenta. A necessidade de suplementação potássica foi observada posteriormente ao plantio, devido à severa deficiência de $\mathrm{K}$ nos primeiros meses pósaplicação do biossólido (PAB). Esta foi realizada a partir do sétimo mês $\mathrm{PAB}$, nos tratamentos $1,3,4,5,7,8$ e 9. O tratamento 6, que recebeu biossólido sem suplementação de $\mathrm{P}$ e $\mathrm{K}$, teve como objetivo avaliar o efeito da ausência de suplementação deste nutriente no crescimento das árvores.

O tratamento 2 (Fertilização Mineral) recebeu $2 \mathrm{t} \mathrm{ha}^{-1}$ de calcário dolomítico, à lanço, em área total, 1 mês antes da instalação do experimento; $300 \mathrm{~kg} \mathrm{ha}^{-1}$ de 6-28-6 no sulco de plantio, $200 \mathrm{~kg} \mathrm{ha}^{-1}$ de 6-10-20 noventa dias pós-plantio e $200 \mathrm{~kg} \mathrm{ha}^{-1}$ de 610-20 sete meses pós-plantio, aplicados em cobertura na projeção da copa. Esta fertilização é usada nas plantações comerciais de eucalipto da Eucatex, definidas a partir de características físicas e químicas do solo. Constitui um tratamento referência em termos de produtividade e efeitos sobre a fertilidade do solo.

O biossólido foi aplicado com pá na superfície do solo, sem incorporação, em faixas de $1 \mathrm{~m}$ de largura na linha de plantio, entre os dias 14 e 17 de agosto de 2001 (Figuras 4c, 4d, 5a a 5d). Após a aplicação do biossólido, foi realizada a subsolagem do solo (60 $\mathrm{cm}$ de profundidade) nas linhas de plantio (Figura 5e e $5 \mathrm{f}$ ). $\mathrm{O}$ adubo fosfatado dos tratamentos $1,3,4,5,7,8,9$ e a adubação de base do tratamento 2 foram aplicados no sulco de subsolagem.

Os tratamentos $1,3,4,5,7,8$ e 9 receberam $126 \mathrm{~kg} \mathrm{ha}^{-1}$ de $\mathrm{P}_{2} \mathrm{O}_{5}$ (superfostato triplo) no sulco de plantio. Esta dose de $\mathrm{P}_{2} \mathrm{O}_{5}$ é equivalente à do tratamento 2. Os mesmos tratamentos receberam suplementação de $\mathrm{K}(\mathrm{KCl})$ de modo que as quantidades de $\mathrm{K}$ contidas no biossólido somadas às do fertilizante potássico ficassem iguais a do tratamento $2\left(98 \mathrm{~kg} \mathrm{ha}^{-1} \mathrm{~K}_{2} \mathrm{O}\right)$. 
Cada parcela experimental foi constituída por 64 árvores (8 linhas de plantio com 8 árvores em cada linha, no espaçamento $3 \mathrm{~m} \times 2 \mathrm{~m}$. Cada parcela ficou com $384 \mathrm{~m}^{2}$ e a área experimental com 1,45 ha. A espécie florestal escolhida para o plantio foi o Eucalyptus grandis Hill ex Maiden (procedente de Coff's Harbour). As mudas usadas no plantio foram obtidas a partir de propagação sexuada (sementes). 
$\mathbf{N}$

Espaçamento de plantio: $3 \mathrm{~m}$ x $2 \mathrm{~m}$,

Área da parcela: $384 \mathrm{~m}^{2}$

Área total=1,5 ha

Blocos

Solo não-degradado (cultivo mínimo)

Solo degradado

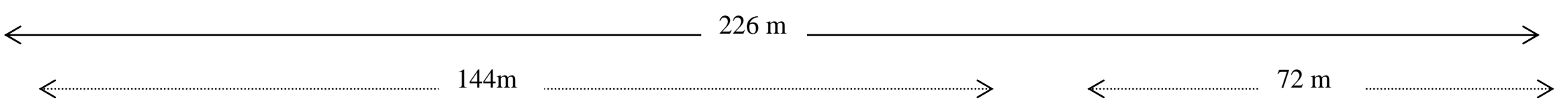

D

\begin{tabular}{|c|c|c|c|c|c|c|c|c|c|}
\hline 5D & $4 \mathrm{D}$ & $2 \mathrm{D}$ & $3 D$ & $6 \mathrm{D}$ & $1 \mathrm{D}$ & & 7D & 9D & $8 D$ \\
\hline $1 \mathrm{C}$ & $6 C$ & $3 C$ & $4 \mathrm{C}$ & $5 C$ & $2 \mathrm{C}$ & & $8 C$ & $9 \mathrm{C}$ & $7 C$ \\
\hline $6 B$ & $5 \mathrm{~B}$ & $4 B$ & $1 \mathrm{~B}$ & $3 B$ & $2 \mathrm{~B}$ & & $9 B$ & $7 \mathrm{~B}$ & $8 B$ \\
\hline $2 \mathrm{~A}$ & $6 \mathrm{~A}$ & $5 \mathrm{~A}$ & $4 \mathrm{~A}$ & $1 \mathrm{~A}$ & $3 \mathrm{~A}$ & 8 & $7 \mathrm{~A}$ & $8 \mathrm{~A}$ & $9 \mathrm{~A}$ \\
\hline
\end{tabular}

Estrada

Figura 3- Disposição dos blocos e tratamentos na área experimental. Nas parcelas em cinza foram monitoradas as taxas de mineralização e lixiviação de N 

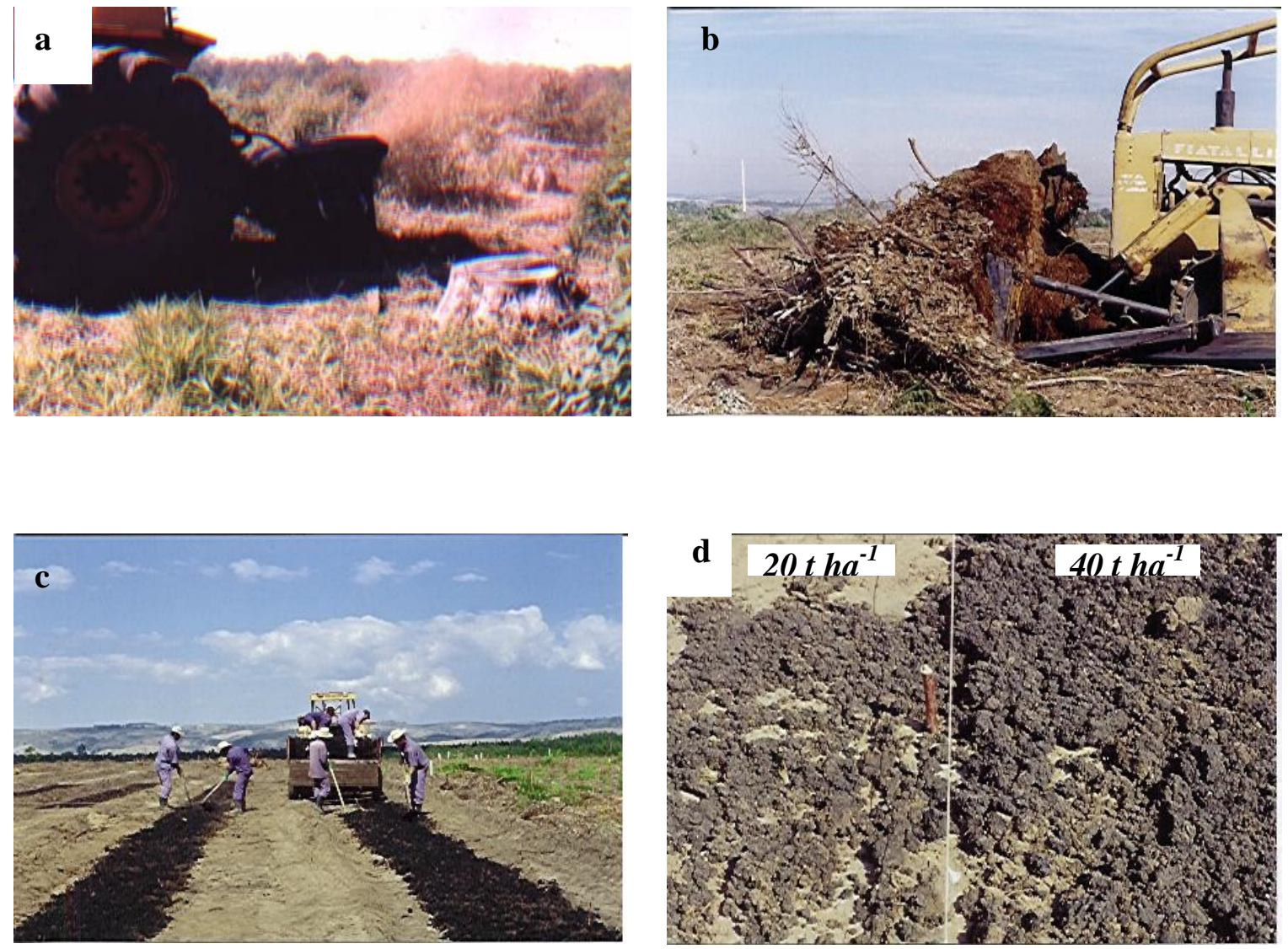

Figura 4- Procedimentos para o preparo do solo degradado. (a) Destocamento dos tocos de eucalipto; (b) remoção da serapilheira e do solo; (c) aplicação de 40 t ha ${ }^{-1}$ do biossólido; (d) superfície do solo com $20 \mathrm{t} \mathrm{ha}^{-1}$ (à esquerda) e $40 \mathrm{t} \mathrm{ha}^{-1}$ do biossólido (à direita) 

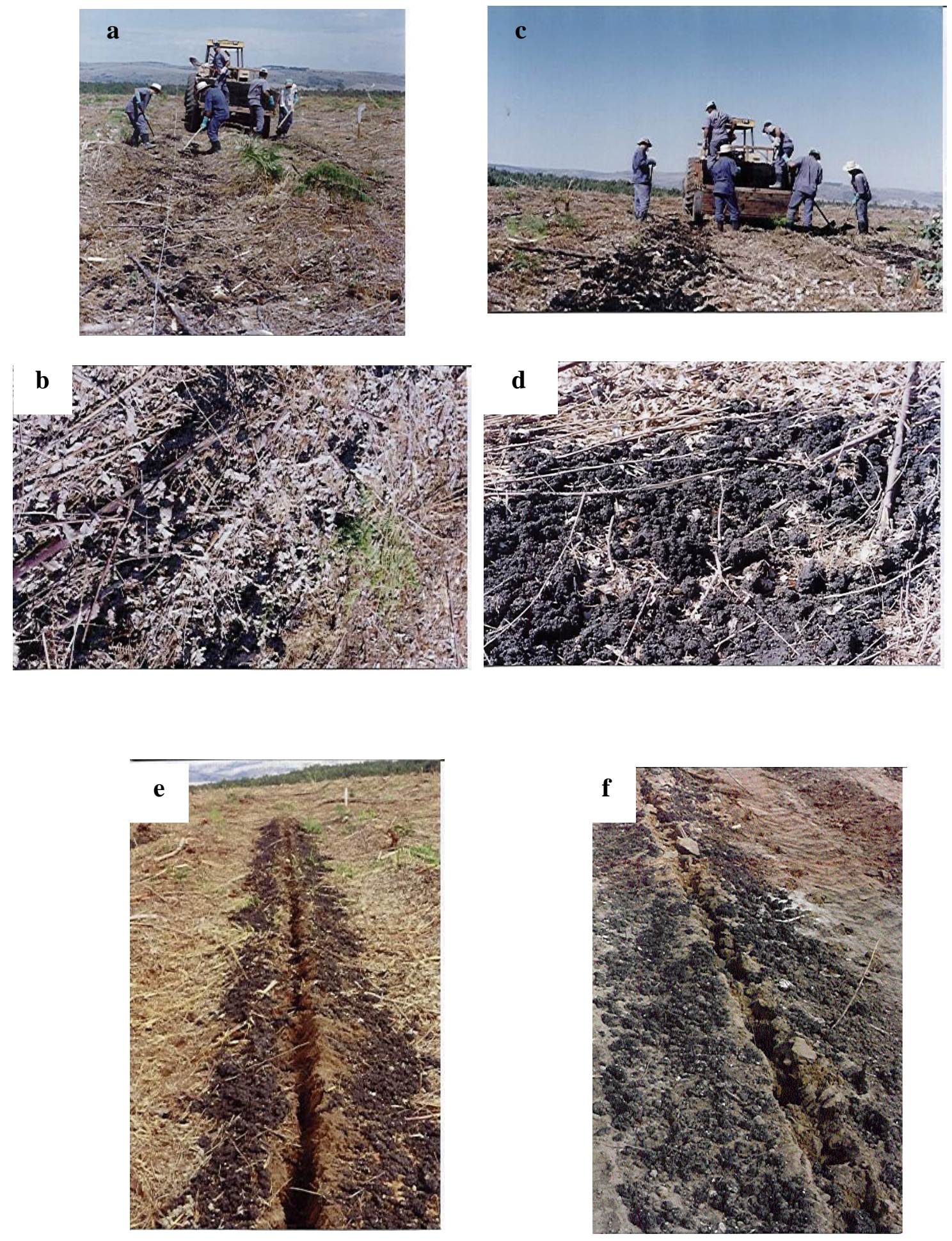

Figura 5- Aplicação, em faixas (1 m), na linha de plantio, de $10 \mathrm{t} \mathrm{ha}^{-1}$ (a e b) e $20 \mathrm{t} \mathrm{ha}^{-1}$ do biossólido (c e d) em solo não-degradado, manejado no sistema de cultivo mínimo. Solo não-degradado (e) e degradado (f) após aplicação do biossólido e subsolagem 


\subsection{Caracterização do solo e da serapilheira antes da aplicação do biossólido}

A descrição morfológica do solo foi realizada segundo Lemos \& Santos (1982) adaptado, observando-se cor, textura, estrutura (tipo, tamanho, grau estruturação), cerosidade, presença de raízes e poros. De cada horizonte diagnóstico obteve-se amostras de terra, que foram posteriormente submetidas à caracterização granulométrica e química (item 3.11).

A amostragem do solo para a caracterização granulométrica e química da área antes da aplicação do biossólido foi realizada nas camadas 0-3, 3-10, 10-20 e 20-30 $\mathrm{cm}$. Para isso, foram coletadas cinco amostras simples destas camadas, em cada parcela, mais uma amostra adicional da camada $30-50 \mathrm{~cm}$ do solo não-degradado, para comparação com o solo degradado. Estas foram reunidas em amostras compostas por grupo de parcelas (seis ao todo, por profundidade) (Figura 6), secas ao ar, homogeneizadas, destorroadas, peneiradas (peneira de $2 \mathrm{~mm}$ ) e analisadas (item 3.11)

A amostragem de serapilheira (solo não-degradado), antes da aplicação do biossólido, foi realizada em cada parcela com um gabarito de madeira de $50 \mathrm{~cm}$ x 50 $\mathrm{cm}$. Seis amostras simples foram reunidas por grupos de parcelas, perfazendo quatro amostras compostas (Figura 6). As amostras foram secas em estufa de circulação forçada a $60^{\circ} \mathrm{C}$, até obtenção de massa constante. Em seguida, foram moídas em moinho tipo Willey e analisadas quimicamente (macronutrientes) (item 3.11).

\subsection{Amostragem da biomassa residual pós-aplicação do biossólido}

Aos sete e aos doze meses PAB, a serapilheira (tratamentos 1 e 2) e serapilheira mais biossólido (tratamentos 3 a 6) foram amostradas na faixa de aplicação do biossólido, com o auxílio de um anel de aço $(30 \mathrm{~cm}$ de diâmetro e $5 \mathrm{~cm}$ de altura), com bordas inferiores em bisel. As amostras foram processadas para análises químicas conforme item 3.4. Uma fração destas amostras foi submetida à moagem adicional em moinho de porcelana, para determinação de $\mathrm{C}$ e de $\mathrm{N}$ totais (item 3.11). 

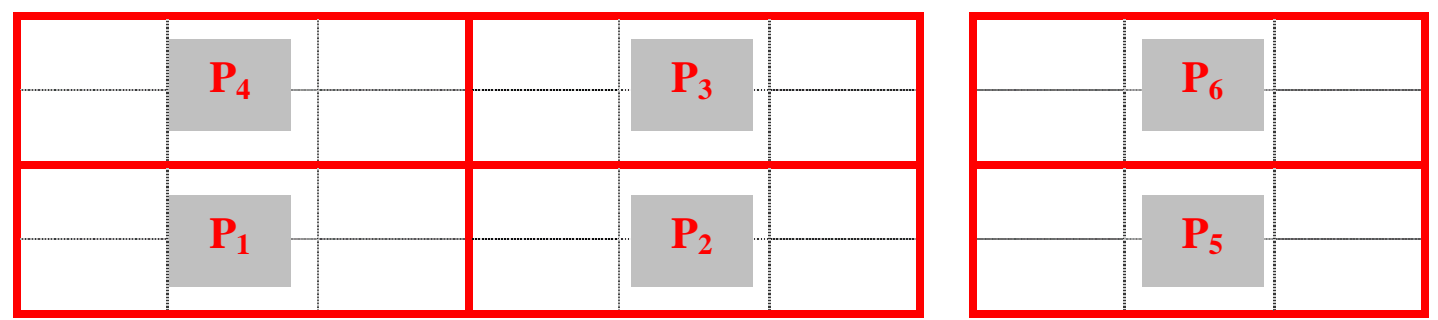

Figura 6- Esquema da área experimental, com divisão em partes (P) para as amostragens da serapilheira e do solo antes da aplicação do biossólido

\subsection{Taxas de mineralização e de lixiviação de $\mathbf{N}$ in situ}

Usou-se o método da incubação do solo in situ, em tubos de PVC, desenvolvido por Adams \& Attiwill (1986) e Raison et al. (1987). Este método permite avaliar simultaneamente as taxas de mineralização e de lixiviação de $\mathrm{N}$, com variação de umidade e temperatura semelhantes ao solo não-incubado, e com mínimo distúrbio. Desta forma, a avaliação foi realizada em condições muito próximas às naturais (não perturbadas).

Devido à alta demanda de tempo, mão-de-obra e recursos materiais, foram avaliadas as concentrações e as taxas de mineralização e de lixiviação de $\mathrm{N}$ apenas nos tratamentos 1, 4 e 8 . O objetivo principal foi comparar as taxas de mineralização e de lixiviação de $\mathrm{N}$ no solo, nos primeiros sete meses pós-aplicação de uma mesma dose de biossólido $\left(20 \mathrm{t} \mathrm{ha}^{-1}\right)$. As avaliações foram realizadas em agosto (24/08 a 12/09), setembro (12/09 a 26/09), novembro de 2001 (14/11 a 28/11) e março de $2002(04 / 03$ a 20/03).

No início de cada período de incubação, foram instalados, na faixa de aplicação do biossólido, três conjuntos de cinco tubos de PVC (35 cm de comprimento e $5 \mathrm{~cm}$ de diâmetro) para as determinações de $\mathrm{N}$ mineralizado e lixiviado, nas camadas de 0-3, 3-10, 10-20 e 20-30 cm do solo (Figuras 7 e 8). Cinco tubos foram removidos e analisados para as determinações das concentrações iniciais de $\mathrm{N}-\mathrm{NH}_{4}{ }^{+}$e de $\mathrm{N}_{-} \mathrm{NO}_{3}{ }^{-}$do solo, da biomassa residual (serapilheira e serapilheira mais biossólido) e do biossólido sobre o solo degradado. Dos dez tubos restantes, cinco foram cobertos para evitar 
lixiviação de $\mathrm{N}$ e cinco foram deixados abertos. Esses tubos permaneceram incubados no campo por 15 a 20 dias.

Após a remoção dos tubos no campo, eles foram envolvidos em gelo e encaminhados ao Laboratório de Microbiologia do Solo do Departamento de Solos e Nutrição de Plantas, ESALQ/USP, onde foram mantidos sob refrigeração a $4^{\circ} \mathrm{C}$ e processados até 3 dias, após sua chegada no laboratório.

Os cilindros de solo foram removidos dos tubos após a separação da serapilheira e então secionados nas camadas de 0-3, 3-10, 10-20 e 20-30 cm. As cinco amostras simples de serapilheira e de cada camada do solo foram reunidas e homogeneizadas, separadamente, dando origem às amostras compostas de serapilheira e das diferentes camadas de solo.

Três sub-amostras de serapilheira, de serapilheira mais biossólido, de biossólido puro e de solo foram separadas para a determinação da umidade, da concentração de N mineral e do pH. Para a determinação do percentual de umidade, as sub-amostras foram secas a $105^{\circ} \mathrm{C}$ por $24 \mathrm{~h}$ (biossólido e solo) e a $60^{\circ} \mathrm{C}$ (serapilheira e serapilheira mais biossólido), até obtenção de massa constante. Para a obtenção dos extratos para determinação de $\mathrm{N}$, foram tomadas $5 \mathrm{~g}$ de serapilheira, serapilheira mais biossólido, biossólido puro e terra úmida, as quais foram agitadas com $50 \mathrm{ml}$ de $\mathrm{KCl} 2$ mol $\mathrm{L}^{-1}$ por $1 \mathrm{~h}$ à temperatura ambiente (Bremner, 1965); estes extratos foram posteriormente filtrados com filtro Watman $n^{\circ} 42$ e armazenados em câmara fria, após receberem $0,1 \mathrm{~mL}$ do inibidor de atividade microbiológica, fenil acetato de mercúrio $\left(0,5 \mathrm{mg} \mathrm{L}^{-1}\right)$. Simultaneamente, $5 \mathrm{~g}$ de cada substrato foi selecionado para a obtenção do pH em $\mathrm{CaCl}_{2}$ 0,01 mol L'-1 no início de cada período de incubação. 


\subsubsection{Determinação das quantidades de $\mathbf{N}$ mineralizadas e lixiviadas}

As equações a seguir foram usadas para determinar as quantidades de $\mathrm{N}$ $\mathrm{NH}_{4}{ }^{+}$e $\mathrm{N}_{-} \mathrm{NO}_{3}^{-}$mineralizado, absorvido e lixiviado no solo durante o perído de amostragem:

$\Delta \mathrm{N}-\mathrm{NH}_{4}{ }^{+}=$amonificação líquida durante o período de incubação $=\mathrm{NH}_{4}{ }^{+}-\mathrm{N}_{\mathrm{i}(\mathrm{t}+1) \mathrm{c}}-\mathrm{NH}_{4}{ }^{+}-\mathrm{N}_{\mathrm{s}(\mathrm{t})}$ $\Delta \mathrm{N}-\mathrm{NO}_{3}{ }^{-}=$nitrificação líquida durante o período de incubação $=\mathrm{NO}_{3}{ }^{-}-\mathrm{N}_{\mathrm{i}(\mathrm{t}+1) \mathrm{c}}-\mathrm{N}_{\mathrm{s}(\mathrm{t})}$ $\Delta \mathrm{Nmin}=$ mineralização líquida $=\Delta \mathrm{N}-\mathrm{NH}_{4}{ }^{+}+\Delta \mathrm{N}-\mathrm{NO}_{3}{ }^{-}$

em que $\mathrm{NH}_{4}{ }^{+}-\mathrm{N}_{\mathrm{s}}$ e $\mathrm{NO}_{3}{ }^{-}-\mathrm{N}_{\mathrm{s}}$ correspondem, respectivamente, às concentrações de $\mathrm{N}$ $\mathrm{NH}_{4}{ }^{+}$e $\mathrm{N}_{-} \mathrm{NO}_{3}{ }^{-}$no solo no início do período de exposição dos tubos (tempo t), enquanto $\mathrm{NH}_{4}{ }^{+}-\mathrm{N}_{\mathrm{i}(\mathrm{t}+1) \mathrm{c}}$ e $\mathrm{NO}_{3}{ }^{-}-\mathrm{N}_{\mathrm{i}(\mathrm{t}+1) \mathrm{c}}$ correspondem, respectivamente, às concentrações de $\mathrm{N}-$ $\mathrm{NH}_{4}{ }^{+}$e $\mathrm{N}-\mathrm{NO}_{3}{ }^{-}$após um determinado período (tempo $\mathrm{t}+1$ ) de exposição do solo, nos tubos que apresentavam a extremidade superior coberta (c).

As perdas constituem variações no conteúdo de $\mathrm{N}$ mineral resultantes da lixiviação, denitrificação e volatilização. Os cálculos utilizados assumem como insignificante as taxas de denitrificação e volatilização. A lixiviação é também assumida como zero nos tubos cobertos (c), sendo máxima nos tubos abertos (a). Neste caso, a perda por lixiviação $\left(\mathrm{N}_{\text {lix }}\right)$ pode ser calculada pela equação:

$$
\mathrm{N}_{\text {lix }}=\left[\mathrm{N}_{\mathrm{i}(\mathrm{t}+1) \mathrm{c}}-\mathrm{N}_{\mathrm{i}(\mathrm{t}+1) \mathrm{a}}\right]
$$

onde $\mathrm{N}_{\mathrm{i}(\mathrm{t}+1) \mathrm{c}}$ é o conteúdo de $\mathrm{N}$ mineral no solo do tubo coberto e $\mathrm{N}_{\mathrm{i}(\mathrm{t}-1) \mathrm{a}}$ é o conteúdo de $\mathrm{N}$ mineral no solo do tubo aberto, ambos no final do período de incubação. 


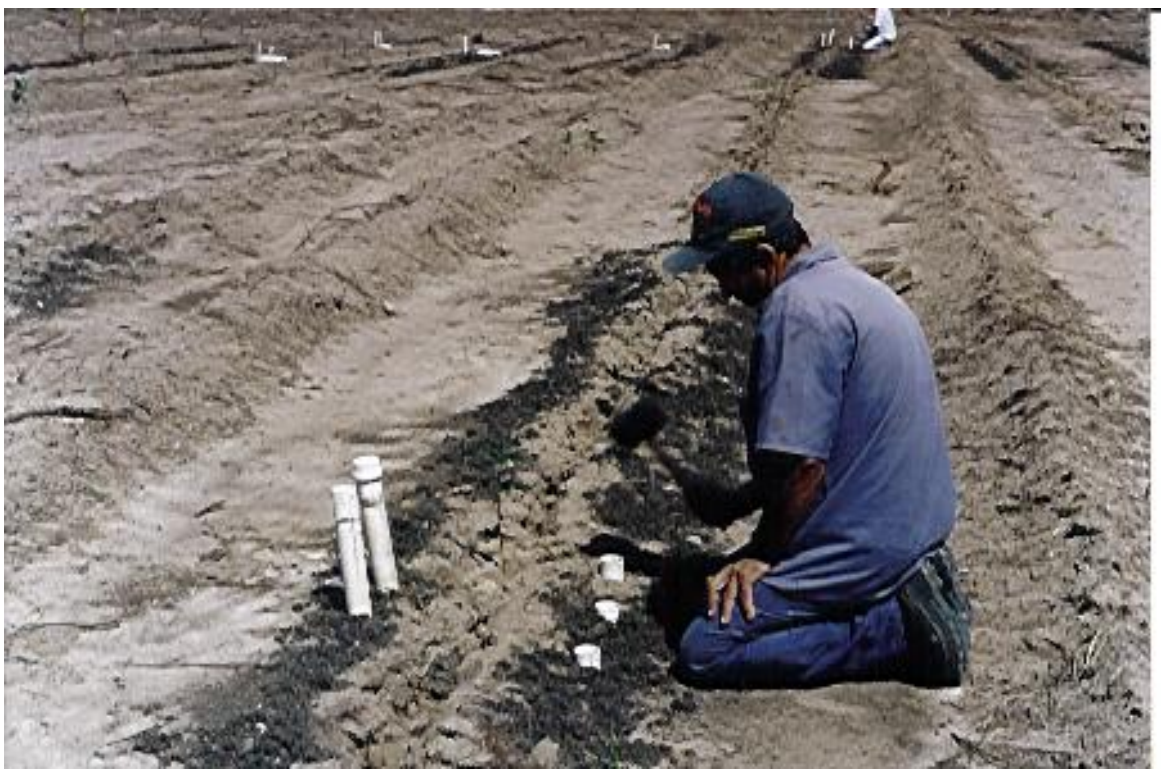

Figura 7- Instalação e retirada dos tubos de PVC para avaliação das taxas de mineralização e de lixiviação de $\mathrm{N}$ in situ, em solo degradado que recebeu $20 \mathrm{t} \mathrm{ha}^{-1}$ de biossólido

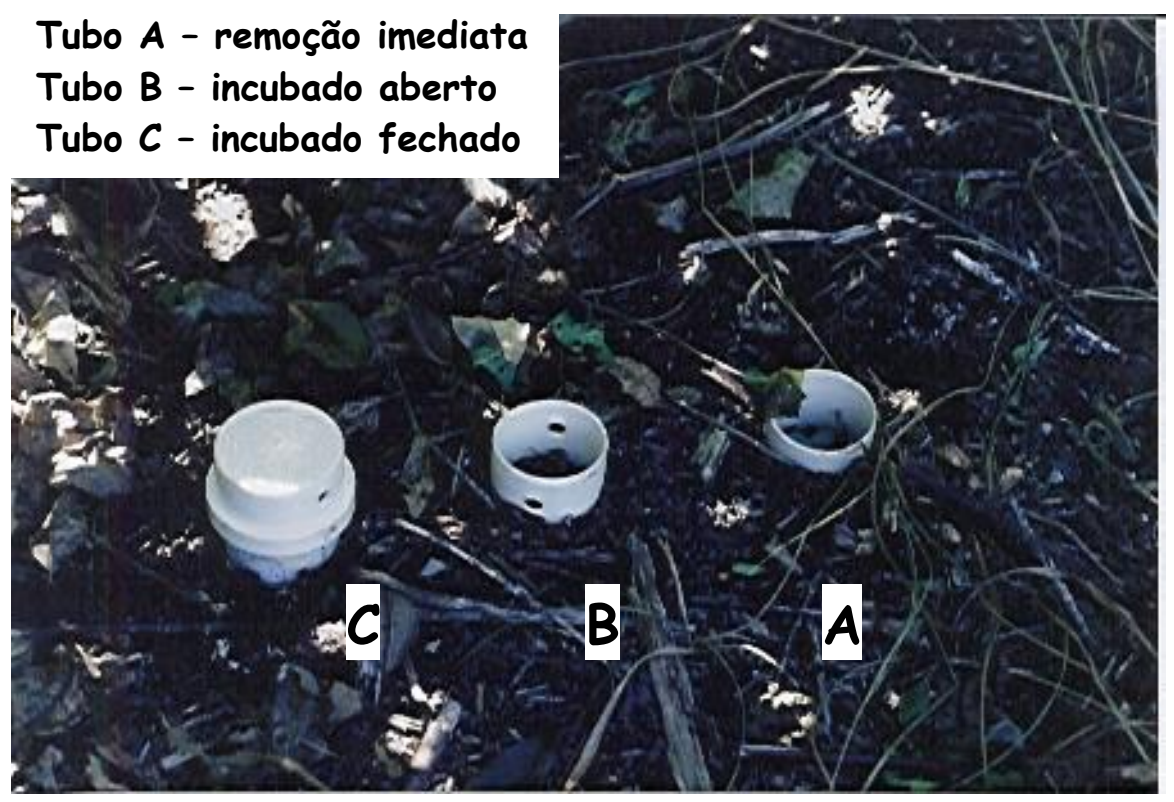

Figura 8- Tubo de PVC em solo não-degradados que recebeu $20 \mathrm{t} \mathrm{ha}^{-1}$ do biossólido, usado para avaliação das taxas de mineralização e de lixiviação de $\mathrm{N}$ in situ (março 2002) 


\subsection{Monitoramento da fertilidade do solo}

Aos sete e aos doze meses PAB, foram obtidas, na faixa de aplicação, amostras compostas de cinco amostras simples por parcela, das camadas 0-3, 3-10, 1020 e 20-30 cm. Estas amostras foram processadas conforme descrito no item 3.4 e analisadas (pH, matéria orgânica, $\mathrm{P}, \mathrm{K}, \mathrm{Ca}, \mathrm{Mg}$ e S) (item 3.11). Uma fração destas amostras foi moída e peneirada a $0,15 \mathrm{~mm}$, para as análises de $\mathrm{C}$ e de $\mathrm{N}$ totais.

\subsection{Mensuração das árvores}

A altura e o diâmetro à altura do peito (DAP) das árvores foram avaliados aos sete, aos doze e aos vinte e dois meses PAB. Nas duas primeiras amostragens, as árvores foram mensuradas com o auxílio de uma vara telescópica e trena; aos vinte e dois meses, foi usado o aparelho "Forester Vertex" e a suta. Foram medidas apenas as dezesseis árvores centrais de cada parcela, ou seja, considerou-se uma bordadura dupla.

\subsection{Análise foliar}

Foram coletadas, do terço superior das árvores, quatro folhas na região mediana dos galhos. Esta amostragem foi realizada em oito árvores escolhidas aleatoriamente na parcela útil, perfazendo uma amostra composta, aos três (somente para $\mathrm{N}$ foliar), aos sete e aos doze meses PAB ( $\mathrm{N}$ e demais macronutrientes). Estas amostras foram secas em estufa de circulação forçada a $60^{\circ} \mathrm{C}$ por 72 horas, para posterior análise.

\subsection{Monitoramento das condições climáticas}

Com o objetivo de se relacionar as condições de clima e as concentrações, as taxas de mineralização e de lixiviação de $\mathrm{N}$, nos primeiros sete - oito meses $\mathrm{PAB}$, foram medidas a pluviosidade e as temperaturas máxima, média e mínima do ar 
41

atmosférico. Esses dados foram obtidos em um pluviômetro/termômetro com sensor de umidade relativa, instalado na sede da Fazenda São Paulo. Neste período, com uso de um termômetro digital, foram mensuradas as temperaturas máximas e mínimas do solo, a 2,5 cm de profundidade, em uma das parcelas com solo não-degradado e em outra com solo degradado, dos tratamentos que receberam $20 \mathrm{t} \mathrm{ha}^{-1}$ de biossólido.

\subsection{Métodos laboratoriais de análise}

\subsubsection{Análises físicas do solo}

A análise granulométrica foi realizada no Laboratório de Física e Mineralogia do Solo do Departamento de Solos e Nutrição de Plantas, ESALQ/USP. Amostras de terra fina seca ao ar (TFSA), passadas em peneira de $2 \mathrm{~mm}$, foram dispersas com hexametafosfato de sódio e hidróxido de sódio $0,1 \mathrm{~mol} \mathrm{~L}^{-1}$. As frações areia (muito grossa, grossa, média, fina e muito fina) foram separadas por peneiramento, a fração argila foi determinada pelo método do densímetro e a fração silte foi calculado por diferença entre estas frações (Camargo et al., 1986).

\subsubsection{Determinações químicas}

$\mathrm{O}$ pH das amostras de serapilheira, da mistura serapilheira mais biossólido, de biossólido puro e de solo foi determinado com potenciômetro, numa relação entre amostra e extrator $\left(\mathrm{CaCl}_{2}\right.$ 0,01 mol L-1) de 1:2,5 (Raij \& Quaggio, 1983); o pH em água e em $\mathrm{KCl}$ também foram determinados no solo, com mesma relação solo:líquido. Nos quatro substratos, o carbono e o $\mathrm{N}$ total foram determinados por combustão a seco $\left(1050^{\circ} \mathrm{C}\right)$ (Nelson \& Sommers, 1982), em aparelho LECO CN 2000. As concentrações de $\mathrm{N}_{-} \mathrm{NH}_{4}{ }^{+}$e $\mathrm{N}_{-} \mathrm{NO}_{3}{ }^{-}$foram determinadas por extração com $\mathrm{KCl}$ e quantificação por condutivimetria e espectrofotometria, respectivamente, em sistema de injeção em fluxo (FIA) (Ruzicka \& Hansen, 1975), de acordo com as seguintes reações: o $\mathrm{N}_{-} \mathrm{NH}_{4}{ }^{+}$é 
convertido a N-NH 3 após alcalininização da amostra com solução de NAOH 1,5 mol L-1 e difuso em uma membrana de TPFE em meio aquoso; o $\mathrm{NH}_{3}$ liberado é coletado por água deionizada, retornando a $\mathrm{NH}_{4}^{+}$e alterando, desta forma, condutividade do meio (Faria \& Pasquini, 1991); o N- $\mathrm{NO}_{3}{ }^{-}$é reduzido a $\mathrm{N}^{-\mathrm{NO}_{2}}{ }^{-}$em uma coluna de $\mathrm{Cd}$, o qual forma com a sulfanilamida, em meio ácido, o diazônio, composto que reage com o N-(1napthyl) ethylenodiamina dicloridato, formando outro composto, cuja intensidade da cor (vemelho-violeta) é determinada ao comprimento de onda de $540 \mathrm{~nm}$ (Gine et al., 1980).

Em amostras de solo, a matéria orgânica foi determinada por oxidação úmida com dicromato de potássio em ácido sulfúrico. $\mathrm{O} \mathrm{Ca}^{2+}, \mathrm{o} \mathrm{Mg}^{2+} \mathrm{e} o \mathrm{~K}^{+}$trocáveis foram extraídos com resina trocadora de íons; os primeiros foram determinados por espectrofotometria de absorção atômica, e o $\mathrm{K}^{+}$por fotometria de emissão de chama. $\mathrm{O}$ $\mathrm{Al}^{3+}$ trocável foi obtido por extração com $\mathrm{KCl} 1 \mathrm{~mol} \mathrm{~L}^{-1}$ e determinado por volumetria de neutralização (Raij \& Quaggio, 1983). $\mathrm{O} \mathrm{H}^{+}+\mathrm{Al}^{3+}$ trocável foi extraído com $\mathrm{KCl} 1$ mol L $\mathrm{L}^{-1}$ e determinado por volumetria com solução diluída de $\mathrm{NaOH}$ (EMBRAPA, 1997); o P foi extraído pelo método da resina trocadora de ânions, e determinado pelo espectrofotômetro com transmissão máxima a $720 \mathrm{~nm}$ ou $885 \mathrm{~nm}$ (EMBRAPA, 1997) e o $\mathrm{S}_{-} \mathrm{SO}_{4}{ }^{2-}$ foi extraído com fosfato monocálcico e determinado por turdibimetria (Cantarella \& Prochnow, 2001). A CTC efetiva, a CTC potencial, a soma de bases, a saturação por bases, a saturação por $\mathrm{Al}$ e o $\Delta \mathrm{pH}$ foram obtidos a partir dos resultados analíticos. Os teores de $\mathrm{SiO}_{2}, \mathrm{Al}_{2} \mathrm{O}_{3}, \mathrm{Fe}_{2} \mathrm{O}_{3}, \mathrm{TiO}_{2}$ e $\mathrm{MnO}$ foram obtidos por solubilização com $\mathrm{H}_{2} \mathrm{SO}_{4}$ 1:1, possibilitando o cálculo dos índices $\mathrm{Ki}$ e $\mathrm{Kr}$.

As concentrações foliares de $\mathrm{N}$ foram obtidas por digestão sulfúrica seguida por determinação pelo método micro-Kjeldhal (Malavolta et al., 1997). As concentrações de $\mathrm{P}, \mathrm{K}, \mathrm{Ca}$ e $\mathrm{Mg}$ das folhas, da serapilheira e da mistura serapilheira mais biossólido foram obtidas por digestão nítrico-perclórica, sendo que $\mathrm{P}$ foi determinado por colorimetria, o K por fotometria de chama, o $\mathrm{S}$ por turbidimetria e os demais elementos por espectrofotometria de absorção atômica (Malavolta et al., 1997). 


\subsection{Conteúdo de nutrientes na serapilheira, na mistura serapilheira mais biossólido e de $\mathbf{N}$ mineral no solo}

Para a estimativa dos conteúdos de N, P, K, Ca, Mg e S totais na mistura serapilheira mais biossólido e de $\mathrm{N}$ mineral no solo não-degradado ( $\mathrm{N}$ mineralizado e $\mathrm{N}$ lixiviado), nos tratamentos que receberam biossólido (3, 4, 5 e 6), foi somado um terço do conteúdo destes nutrientes, obtido na faixa de aplicação do biossólido (um terço da área), a dois terços dos conteúdos dos mesmos, obtidos na entrelinha de plantio; estes últimos foram estimados a partir dos conteúdos obtidos no Controle (tratamento 1). Os conteúdos de $\mathrm{N}$ mineral do solo degradado foram estimados a partir da soma de um terço do conteúdo determinado na faixa de aplicação a dois terços dos conteúdos obtidos na camada 20-30 cm do Controle em solo não-degradado (tratamento 1) (valores médios). Constitui a estimativa mais próxima, dado o não monitoramento do Controle em solo degradado (tratamento 7).

\subsection{Análise estatística}

A análise de variância (ANOVA) foi realizada para verificar a significância dos efeitos de tratamento para os dados da biomassa residual (serapilheira e serapilheira mais biossólido), composição química desta, do solo, da análise foliar e do crescimento das árvores nas duas idades de amostragem. Quando detectada significância na diferença entre tratamentos, foram realizadas análises de regressão polinomial linear e quadrática. Análises de regressões múltiplas para a seleção de variáveis (tipo "backward") também foram realizadas a fim de verificar as relações entre o crescimento das árvores (altura e DAP) e a concentração de nutrientes nas folhas das árvores.

Para as taxas e as concentrações de $\mathrm{N}$ mineral no solo utilizou-se o procedimento GLM (General Linear Model), avaliando-se os efeitos de tratamento, época, e interação entre estes. Quando houve efeito significativo de tratamentos, sem interação, realizou-se o teste de Tukey a 5\% de probabilidade, e quando houve efeito 
significativo de épocas e, ou interação entre épocas e tratamentos, foram realizadas análises de regressões.

Para a análise dos dados de mineralização e lixiviação de $\mathrm{N}$ in situ, foi necessária a transformação dos dados, pois foi detectada heterogeneidade de variância. Os valores originais das taxas de lixiviação de $\mathrm{N}_{-} \mathrm{NH}_{4}{ }^{+}$foram elevados a potência 1,2, os das taxas de nitrificação foram transformados em seu logarítimo na base 10 e os das taxas de amonificação, mineralização de $\mathrm{N}$ total, lixiviação do $\mathrm{N}^{-\mathrm{NO}_{3}}{ }^{-}$e de $\mathrm{N}$ mineral total foram transformados em valores positivos com a soma de constantes. Depois, foram realizadas as análises de variância da regressão, com seus respectivos desdobramentos, quando necessário, e o ajuste dos modelos de regressão obtidos para o fator época, a partir de todos os pontos amostrados (dados não transformados), utilizando o software Sigma Plot 4.0 (Jandel Scientific). Para as taxas de mineralização de $\mathrm{N}$ no solo não-degradado sem aplicação de biossólido, também foi ajustado um modelo de cinética de primeira ordem $\left(\mathrm{Nt}=\mathrm{N}_{\mathrm{o}}+\mathrm{b} / \mathrm{t}\right)$, proposto por Gonçalves et al. (2001) para solos florestais, onde Nt é o N mineralizado acumulado até o tempo t (dias), $\mathrm{N}_{0}$ é o $\mathrm{N}$ potencialmente mineralizável e b é o parâmetro a ser estimado. 


\section{RESULTADOS E DISCUSSÃO}

\subsection{Caracterização do solo antes da aplicação do biossólido}

Pela observação macromorfológica pôde-se distinguir, no perfil do solo, dois centímetros de material orgânico em sua superfície (serapilheira). O horizonte superficial $(0-15 \mathrm{~cm})$ é caracterizado pela cor escura, agregados granulares, grande acúmulo de matéria orgânica (MO), maior ocorrência de raízes finas e intensa atividade biológica. Os horizontes de transição AB $(15-27 \mathrm{~cm})$ e BA $(27-55 \mathrm{~cm})$ são seguidos pelo horizonte B latossólico $(55-80+\mathrm{cm})$, caracterizado por matiz laranja (5 YR 4,5/6), com blocos subangulares fracamente estruturados que se desfazem em microagregados, grande microporosidade e ocorrência apenas de raízes grossas.

O solo apresenta de 160 a $220 \mathrm{~g} \mathrm{~kg}^{-1}$ de argila, concentração de silte variando de 40 a $80 \mathrm{~g} \mathrm{~kg}^{-1}$ e predominância de areias médias (300 a $\left.380 \mathrm{~g} \mathrm{~kg}^{-1}\right)(0,5 \mathrm{a}$ $0,25 \mathrm{~mm})$ e finas $\left(230\right.$ a $\left.320 \mathrm{~g} \mathrm{~kg}^{-1}\right)(0,25$ a $0,1 \mathrm{~mm})$ (Tabela 2). A partir da relação molecular $\mathrm{SiO}_{2} /\left(\mathrm{Al}_{2} \mathrm{O}_{3}+\mathrm{Fe}_{2} \mathrm{O}_{3}\right), \mathrm{Kr}$, do horizonte $\mathrm{B}$ latossólico, (maior que 0,75) (Embrapa, 1999), concluiu-se que o solo em estudo é predominantemente caulinítico (Tabela 3). No entanto, abaixo de $15 \mathrm{~cm}$, as concentrações de $\mathrm{Al}_{2} \mathrm{O}_{3}$ são maiores do que as concentrações de $\mathrm{SiO}_{2}$, indicando também a presença de óxidos de $\mathrm{Al}$ no solo. $\mathrm{O}$ pH em $\mathrm{KCl}$ foi inferior ao $\mathrm{pH}$ em água em todos os horizontes amostrados, resultando em valores de $\Delta \mathrm{pH}$ negativo, o que caracteriza caráter eletronegativo ao solo (Tabela 4). A acidez do solo é alta ( $\mathrm{pH} \mathrm{CaCl} 2$ entre 3,1 e 4,1) e a fertilidade baixa, com concentrações de MO e de nutrientes predominando nos cinco primeiros centímetros do solo, baixo valores de saturação por bases, CTC formada principalmente por H e Al trocáveis, 
conferindo ao solo alta saturação por $\mathrm{Al}$ (73 a $85 \%)$.

Tabela 2. Composição granulométrica dos horizontes do solo

\begin{tabular}{ccccccccccc}
\hline & \multicolumn{9}{c}{ Areia $^{(\mathbf{1})}$} & \multicolumn{5}{c}{$\begin{array}{c}\text { Argila } \\
\text { Prof. }\end{array}$} & MG & G & M & F & MF & Total & Silte & Total & Agua & Floculação \\
\hline & & & & & & & & & & \\
& & & & & & & & & & \\
$2-5$ & 10 & 100 & 360 & 230 & 50 & 750 & 60 & 190 & 60 & 67 \\
$5-15$ & 0 & 50 & 380 & 260 & 70 & 760 & 80 & 160 & 60 & 63 \\
$15-27$ & 10 & 50 & 340 & 320 & 60 & 780 & 40 & 180 & 60 & 67 \\
$27-55$ & 10 & 40 & 300 & 300 & 90 & 740 & 60 & 200 & 40 & 80 \\
$55-80$ & 10 & 80 & 320 & 270 & 60 & 740 & 60 & 200 & 60 & 70 \\
$80-+$ & 10 & 40 & 300 & 270 & 80 & 700 & 80 & 220 & 40 & 82 \\
\hline
\end{tabular}

${ }^{(1)}$ MG: areia muito grossa; G: areia grossa; M: areia média; F: areia fina; MF: areia muito fina.

Tabela 3. Elementos totais dos horizontes do solo

\begin{tabular}{|c|c|c|c|c|c|c|c|}
\hline Prof. & $\mathrm{SiO}_{2}$ & $\mathbf{A l}_{2} \mathbf{O}_{3}$ & $\mathrm{Fe}_{2} \mathrm{O}_{3}$ & $\mathrm{TiO}_{2}$ & MnO & $\mathbf{K i}^{(\mathbf{1})}$ & $K r^{(1)}$ \\
\hline \multicolumn{8}{|l|}{$\mathrm{cm}$} \\
\hline $2-5$ & 69,0 & 27,0 & 12,4 & 1,2 & 0,1 & 4,34 & 3,36 \\
\hline $5-15$ & 31,0 & 36,8 & 12,9 & 1,3 & 0,1 & 1,43 & 1,17 \\
\hline $15-27$ & 25,0 & 35,7 & 14,3 & 1,9 & 0,1 & 1,19 & 0,95 \\
\hline $27-55$ & 26,0 & 48,6 & 16,9 & 2,0 & 0,1 & 0,91 & 0,74 \\
\hline $55-80$ & 34,0 & 47,7 & 17,0 & 2,2 & 0,1 & 1,21 & 0,99 \\
\hline $80-+$ & 41,0 & 54,2 & 17,8 & 2,3 & 0,1 & 1,29 & 1,06 \\
\hline
\end{tabular}

${ }^{(1)} \mathrm{Ki}$ : índice $\mathrm{Ki}=\left(\mathrm{SiO}_{2} / 60\right) /\left(\mathrm{Al}_{2} \mathrm{O}_{3} / 102\right) ; \mathrm{Kr}$ : índice $\mathrm{Kr}=\left(\mathrm{SiO}_{2} / 60\right) /\left[\left(\mathrm{Al}_{2} \mathrm{O}_{3} / 102\right)+\left(\mathrm{Fe}_{2} \mathrm{O}_{3} / 106\right)\right]$ 
Tabela 4. Atributos químicos dos horizontes do solo

\begin{tabular}{|c|c|c|c|c|c|c|c|c|c|c|c|c|c|c|}
\hline \multicolumn{15}{|c|}{ pH } \\
\hline $\mathrm{cm}$ & & & & \multicolumn{2}{|c|}{$-\mathrm{g} \mathrm{dm}^{-3}$} & \multicolumn{7}{|c|}{$\mathrm{mmol}_{\mathrm{c}} \mathrm{kg}^{-1}$} & \multicolumn{2}{|c|}{$\%$} \\
\hline $2-5$ & 3,8 & 2,9 & 3,1 & 13 & 8 & 0,5 & 9 & 3 & 34 & 153 & 12,5 & 165,5 & 8 & 73 \\
\hline $5-15$ & 4,1 & 3,7 & 3,8 & 18 & 4 & 0,2 & 3 & 2 & 23 & 72 & 5,2 & 77,2 & 7 & 82 \\
\hline $15-27$ & 4,3 & 3,9 & 3,9 & 9 & 2 & 0,3 & 1 & 1 & 17 & 47 & 2,3 & 49,3 & 5 & 88 \\
\hline $27-55$ & 4,3 & 4,1 & 4,0 & 9 & 1 & 0,4 & 1 & 1 & 14 & 33 & 2,4 & 35,4 & 7 & 85 \\
\hline $55-80$ & 4,4 & 4,1 & 4,0 & 6 & 1 & 0,3 & 1 & 1 & 12 & 27 & 2,3 & 29,3 & 8 & 84 \\
\hline $80-+$ & 4,6 & 4,1 & 4,1 & 6 & 1 & 0,3 & 1 & 1 & 10 & 28 & 2,3 & 30,3 & 8 & 81 \\
\hline
\end{tabular}

${ }^{(1)} \mathrm{SB}$ : soma de bases $\left(\mathrm{K}^{+}+\mathrm{Ca}^{2+}+\mathrm{Mg}^{2+}\right)$; $\mathrm{CTC}$ : capacidade de troca catiônica ( $\left.\mathrm{SB}+\mathrm{H}+\mathrm{Al}\right)$; V\%: porcentagem de saturação por bases (SB x 100/CTC) e m\%: saturação por alumínio (Al x 100/CTC $\mathrm{Cf}_{\mathrm{ef}}$ ).

Com a remoção do topo do horizonte A e a exposição das camadas subsuperficiais, não houve alterações significativas nos atributos granulométricos do solo (Tabela 5), mas a camada $0-30 \mathrm{~cm}$ do solo degradado passou a apresentar maior densidade do solo e menor fertilidade (Tabelas 6 e 7).

Tabela 5. Composição granulométrica de diferentes camadas do solo, após a remoção da camada superficial e antes da aplicação do biossólido

\begin{tabular}{|c|c|c|c|c|c|c|c|c|c|c|}
\hline \multirow[t]{2}{*}{ Prof. } & \multicolumn{6}{|c|}{ Areia } & \multicolumn{4}{|c|}{ Argila } \\
\hline & MG & G & $\mathbf{M}$ & $\mathbf{F}$ & MF & Total & Silte & Total & Agua & Floculação \\
\hline $\mathrm{cm}$ & & & & & & $\mathrm{g} \mathrm{kg}^{-1}$ & & & & \multirow[t]{2}{*}{$\%$} \\
\hline \multicolumn{10}{|c|}{ Solo não-degradado } & \\
\hline $0-3$ & 0 & 80 & 470 & 210 & 20 & 780 & 70 & 160 & 80 & 48 \\
\hline $3-10$ & 0 & 70 & 480 & 210 & 20 & 780 & 70 & 160 & 80 & 48 \\
\hline $10-20$ & 0 & 70 & 460 & 240 & 20 & 780 & 60 & 160 & 90 & 47 \\
\hline $20-30$ & 0 & 60 & 340 & 250 & 30 & 670 & 70 & 260 & 70 & 54 \\
\hline $30-50$ & 0 & 70 & 500 & 190 & 30 & 780 & 50 & 170 & 30 & 82 \\
\hline \multicolumn{11}{|c|}{ Solo degradado } \\
\hline $0-3$ & 0 & 50 & 370 & 340 & 20 & 780 & 80 & 140 & 60 & 57 \\
\hline $3-10$ & 0 & 50 & 340 & 390 & 20 & 800 & 60 & 140 & 60 & 57 \\
\hline $10-20$ & 0 & 40 & 340 & 380 & 20 & 780 & 80 & 140 & 60 & 57 \\
\hline $20-30$ & 0 & 40 & 440 & 300 & 20 & 800 & 60 & 140 & 40 & 71 \\
\hline
\end{tabular}

${ }^{(1)}$ MG: areia muito grossa; G: areia grossa; M: areia média; F: areia fina; MF: areia muito fina. 
Tabela 6. Densidade do solo (média \pm erro padrão) logo após a instalação do experimento

\begin{tabular}{|c|c|c|c|}
\hline \multirow[t]{2}{*}{ Profundidade } & \multirow{2}{*}{$\begin{array}{c}\text { Controle } \\
\text { Solo não-degrad. }\end{array}$} & \multicolumn{2}{|c|}{20 t ha ${ }^{-1}$ de biossólido } \\
\hline & & Solo não-degradado & Solo degradado \\
\hline $\mathrm{cm}$ & & $\mathrm{g} \mathrm{cm}^{-3}$ & \\
\hline $0-3$ & $0,52 \pm 0,15$ & $0,55 \pm 0,15$ & $1,15 \pm 0,10$ \\
\hline $3-10$ & $1,15 \pm 0,08$ & $1,26 \pm 0,01$ & $1,41 \pm 0,09$ \\
\hline $10-20$ & $1,34 \pm 0,08$ & $1,24 \pm 0,15$ & $1,49 \pm 0,04$ \\
\hline $20-30$ & $1,38 \pm 0,05$ & $1,27 \pm 0,16$ & $1,51 \pm 0,05$ \\
\hline
\end{tabular}

Tabela 7. Composição química de diferentes camadas do solo, após a remoção da camada superficial e antes da aplicação do biossólido

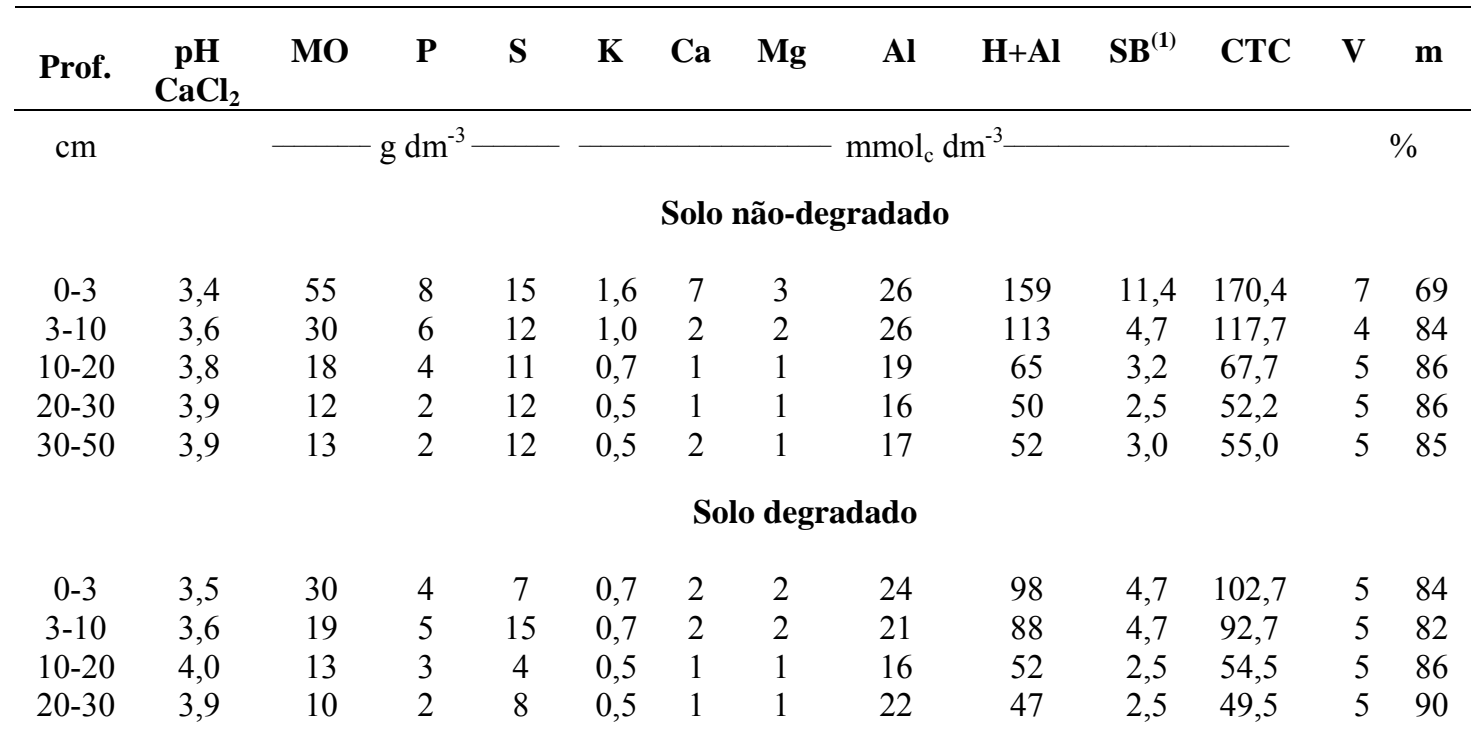

${ }^{(1)} \mathrm{SB}$ : soma de bases $\left(\mathrm{K}^{+}+\mathrm{Ca}^{++}+\mathrm{Mg}^{++}\right)$; $\mathrm{CTC}$ : capacidade de troca catiônica $(\mathrm{SB}+\mathrm{H}+\mathrm{Al})$; $\mathrm{V} \%$ : porcentagem de saturação por bases (SB x 100/CTC) e m\%: saturação por alumínio (Al x 100/CTC $\mathrm{ef}_{\mathrm{f}}$ ). 


\subsection{Biomassa residual e características químicas da serapilheira e da mistura serapilheira mais biossólido, acumulados sobre o solo}

\subsubsection{Biomassa residual}

A quantidade média de serapilheira residual presente antes da instalação do experimento foi de $34 \mathrm{t} \mathrm{ha}^{-1}$, valor próximo aos observados sete meses pós-aplicação do biossólido (PAB) no tratamento Controle (Tabela 8). Não houve diferenças significativas entre a quantidade de serapilheira acumulada no período que antecede a aplicação do biossólido e aos sete meses PAB, nos tratamentos com aplicação de 10, $20 \mathrm{t}$ $\mathrm{ha}^{-1}$ de biossólido mais suplementação de $\mathrm{P}$ e $\mathrm{K}$ e $10 \mathrm{t} \mathrm{ha}^{-1}$ de biossólido sem suplementação de P e K. A similaridade de valores expressa a maior massa do biossólido aplicado sobre a serapilheira (30 a $120 \mathrm{t} \mathrm{ha}^{-1}$ do biossólido, base seca, sobre $11 \mathrm{t} \mathrm{ha}^{-1} \mathrm{de}$ serapilheira, na faixa de $1 \mathrm{~m}$ onde foi aplicado o resíduo), fato que mascarou a decomposição da serapilheira.

Aos doze meses PAB, a quantidade de biomassa acumulada nos diferentes tratamentos foi duas a três vezes menor do que a observada na coleta anterior, evidenciando sua intensa decomposição (Tabela 8). Neste período, foi mais evidente o aumento da quantidade de resíduos acumulados na superfície do solo proporcional às doses crescentes de biossólido. No tratamento que recebeu $40 \mathrm{t} \mathrm{ha}^{-1}$ de biossólido (5), a biomassa residual foi, aos sete meses, duas vezes e, aos doze meses, duas a quatro vezes maior do que a dos demais tratamentos. A menor degradabilidade do biossólido em grandes quantidades foi também observada por Agbim et al. (1977); Mattiazzo et al. (1998), Barreto (1995); Sui et al. (1999) e Boeira et al., (2002). Este efeito pode estar relacionado à presença de espécies químicas tóxicas, que causam modificações na diversidade e na fisiologia da microbiota do substrato (Lopes, 2001).

$\mathrm{Na}$ mesma época, a biomassa da mistura serapilheira mais biossólido no tratamento que recebeu $10 \mathrm{t} \mathrm{ha}^{-1}$ de biossólido mais suplementação de $\mathrm{P}$ e de $\mathrm{K}$ (tratamento 3), aos doze meses $\mathrm{PAB}$, foi $40 \%$ menor do que o tratamento que recebeu a mesma dose de biossólido, mas sem suplementação de fertilizante mineral (tratamento 
6) (Tabela 8). Desta forma, a aplicação de fertilizantes aumentou a taxa de decomposição dos resíduos, o que também deve ter contribuído para o maior crescimento das árvores neste tratamento.

Nos tratamentos Controle (1) e fertilização mineral (2), observou-se diminuição de 77 e $50 \%$ da biomassa de serapilheira acumulada, respectivamente, entre sete e doze meses PAB, evidenciando intensa taxa de mineralização (Tabela 8). A menor biomassa de serapilheira no tratamento Controle pode ser devido: i) a menor queda de folhedo em relação aos demais tratamentos, decorrente do menor crescimento das árvores, ocasionada pela baixa fertilidade do solo (Madeira et al., 1995); ii) a maior incidência de radiação solar na superfície do solo (menor copa), o que aumenta a temperatura do solo (Kolm, 2001; Martins, 2002) e a atividade microbiana; iii) a maior atividade do sistema radicular e rizosfera nas camadas superficiais do solo de baixa fertilidade (Gonçalves, 1994; Martins, 2002).

Tabela 8. Biomassa residual de serapilheira e da mistura serapilheira mais biossólido na faixa de $1 \mathrm{~m}$ de aplicação do biossólido (média \pm desvio padrão), aos sete e aos doze meses pósaplicação do biossólido (PAB), e diminuição da massa da serapilheira entre sete e doze meses PAB

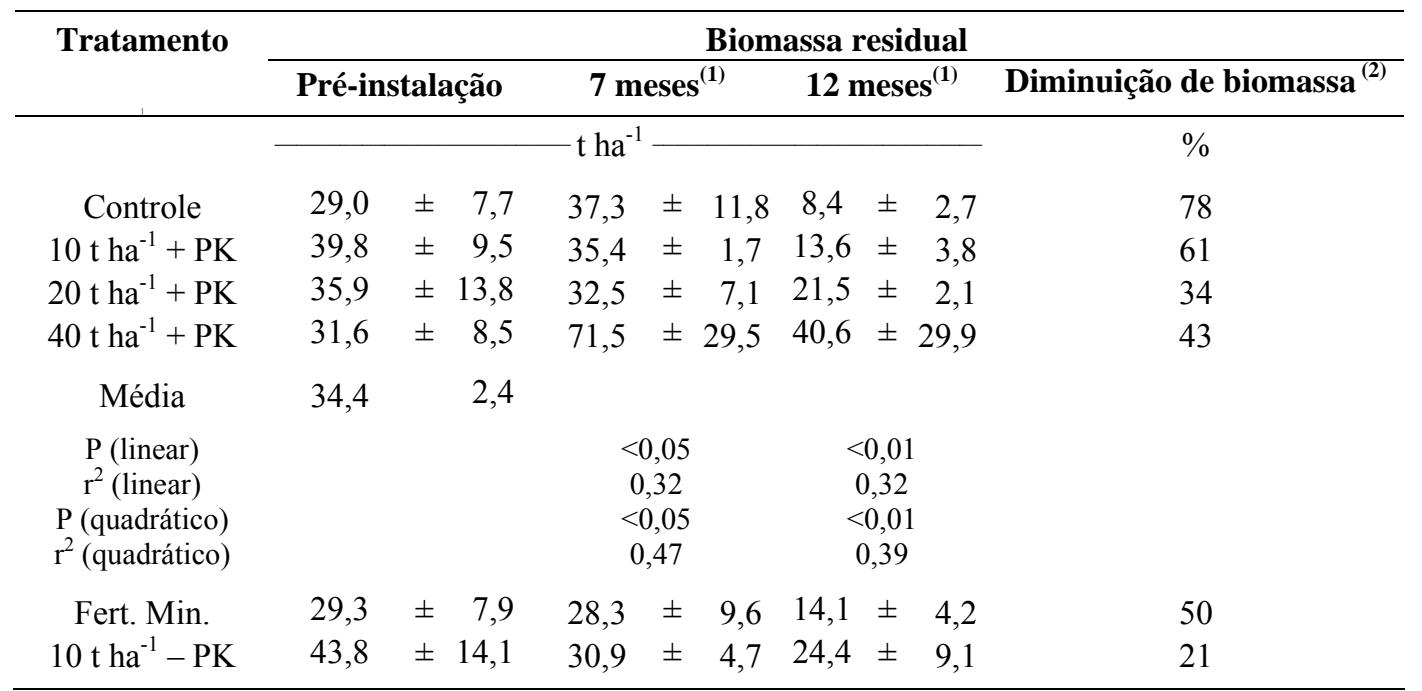

(1) Biomassa coletada na faixa de aplicação do biossólido $(1 \mathrm{~m})$;

(2) Diminuição da biomassa de serapilheira entre sete e doze meses pós-aplicação do biossólido (faixa de $1 \mathrm{~m}$ ). 


\subsubsection{Características químicas}

\subsubsection{1 $\mathrm{pH}$}

$\mathrm{Na}$ serapilheira do tratamento Controle, não houve alterações significativas do $\mathrm{pH}$ durante 199 dias PAB (valor médio 4,2) (Tabela 9). A mistura serapilheira mais $20 \mathrm{t} \mathrm{ha}^{-1}$ de biossólido apresentou aumento de $\mathrm{pH}$, de 4,3 para 6,1, possivelmente pela ação direta do biossólido (efeito mistura). Neste período, apesar do valor médio do $\mathrm{pH}$ do biossólido puro no solo degradado ter sido maior do que a mistura serapilheira mais biossólido, estes não diferiram entre si no primeiro mês $(P<0,01)$. Após o primeiro mês de aplicação do biossólido, houve diminuição gradual do $\mathrm{pH}$ nos dois tratamentos que receberam biossólido. $\mathrm{O}$ aumento do $\mathrm{pH}$ nos primeiros dias de contato do biossólido com o solo, seguido de diminuição, também foi observado por Lopes (2001), Reis \& Rodella (2002) e Boeira et al. (2002), em biossólido misturado ao solo e incubado em condições de laboratório. Esta diminuição pode estar relacionada ao aumento dos processos de nitrificação, que promovem a liberação de prótons e favorecem a lixiviação de cátions (Harrison et al., 1996).

Aos 199 dias PAB, o pH da serapilheira mais biossólido, apesar de média maior $(4,7)$, não diferiu do tratamento Controle $(4,2)(P<0,01)$ (Tabela 9). Esta menor influência do biossólido sobre o $\mathrm{pH}$ pode estar combinada aos processos de acidificação, resultantes da acumulação e decomposição de $\mathrm{MO}$, da lixiviação de nutrientes e da absorção de cátions pelas raízes das árvores (Van Miegroet \& Johnson, 1993). Neste período, apenas o $\mathrm{pH}$ do biossólido puro diferiu do tratamento Controle $(\mathrm{P}<0,01)$. 
Tabela 9. Variação do pH da serapilheira e da mistura serapilheira mais biossólido nos primeiros sete meses pós-aplicação do biossólido $(\mathrm{PAB})^{(1)}$

\begin{tabular}{|c|c|c|c|}
\hline \multirow[b]{2}{*}{ Tempo } & \multirow{2}{*}{$\begin{array}{c}\text { Controle } \\
\text { Tratamento } 1\end{array}$} & \multicolumn{2}{|c|}{20 t ha ${ }^{-1}$ biossólido } \\
\hline & & Solo não-degrad. & Solo degrad. \\
\hline \multicolumn{4}{|l|}{ dia PAB } \\
\hline 7 & $4,32 \mathrm{a}$ & $6,13 \mathrm{~b}$ & $6,73 \mathrm{~b}$ \\
\hline 26 & $4,14 \mathrm{a}$ & $5,34 \mathrm{~b}$ & $6,06 \mathrm{~b}$ \\
\hline 89 & $4,14 \mathrm{a}$ & $5,75 \mathrm{~b}$ & $6,41 \mathrm{~b}$ \\
\hline 199 & $4,18 \mathrm{a}$ & $4,73 \mathrm{ab}$ & $5,17 \mathrm{~b}$ \\
\hline
\end{tabular}

\subsubsection{Concentração de $\mathrm{C}$ e de $\mathrm{N}$ totais}

Aos sete meses $\mathrm{PAB}$, na biomassa residual sobre o solo, houve diminuição linear das concentrações de $\mathrm{C}$ e aumento linear das concentrações de $\mathrm{N}$ $(\mathrm{P}<0,01)$ com o aumento das doses de biossólido (Figura 9). $\mathrm{O}$ aumento do aporte de $\mathrm{N}$ na biomassa residual ocasionou diminuição quadrática da relação $\mathrm{C} / \mathrm{N}$ da serapilheira mais biossólido ( $\mathrm{P}<0,05)$, resultado também observado por Bramryd (2001) após onze anos de aplicação do biossólido na superfície de um Espodossolo sob cultivo com pinus. Além do efeito mistura (biossólido - C/N 8/1; serapilheira - C/N 49/1), a diminuição da relação $\mathrm{C} / \mathrm{N}$ deve ter sido causada pelo aumento da taxa de mineralização da fração lábil do $\mathrm{C}$, maior do que a quantidade de $\mathrm{C}$ imobilizada pelos microorganismos (Fortes Neto, 2000).

Dos sete aos doze meses PAB, houve diminuição das concentrações de C no tratamento Controle (1) e semelhança entre as concentrações de $C$ da serapilheira mais biossólido, nas diferentes doses de biossólido aplicadas (Figura 9). Neste período, pode-se estabelecer função quadrática das concentrações de $\mathrm{N}$ e da relação $\mathrm{C} / \mathrm{N}$ com as doses crescentes do biossólido $(\mathrm{P}<0,05)$. Os resultados obtidos indicam que a mineralização do $\mathrm{N}$ não ocorreu de forma homogênea para as diferentes doses de biossólido. 

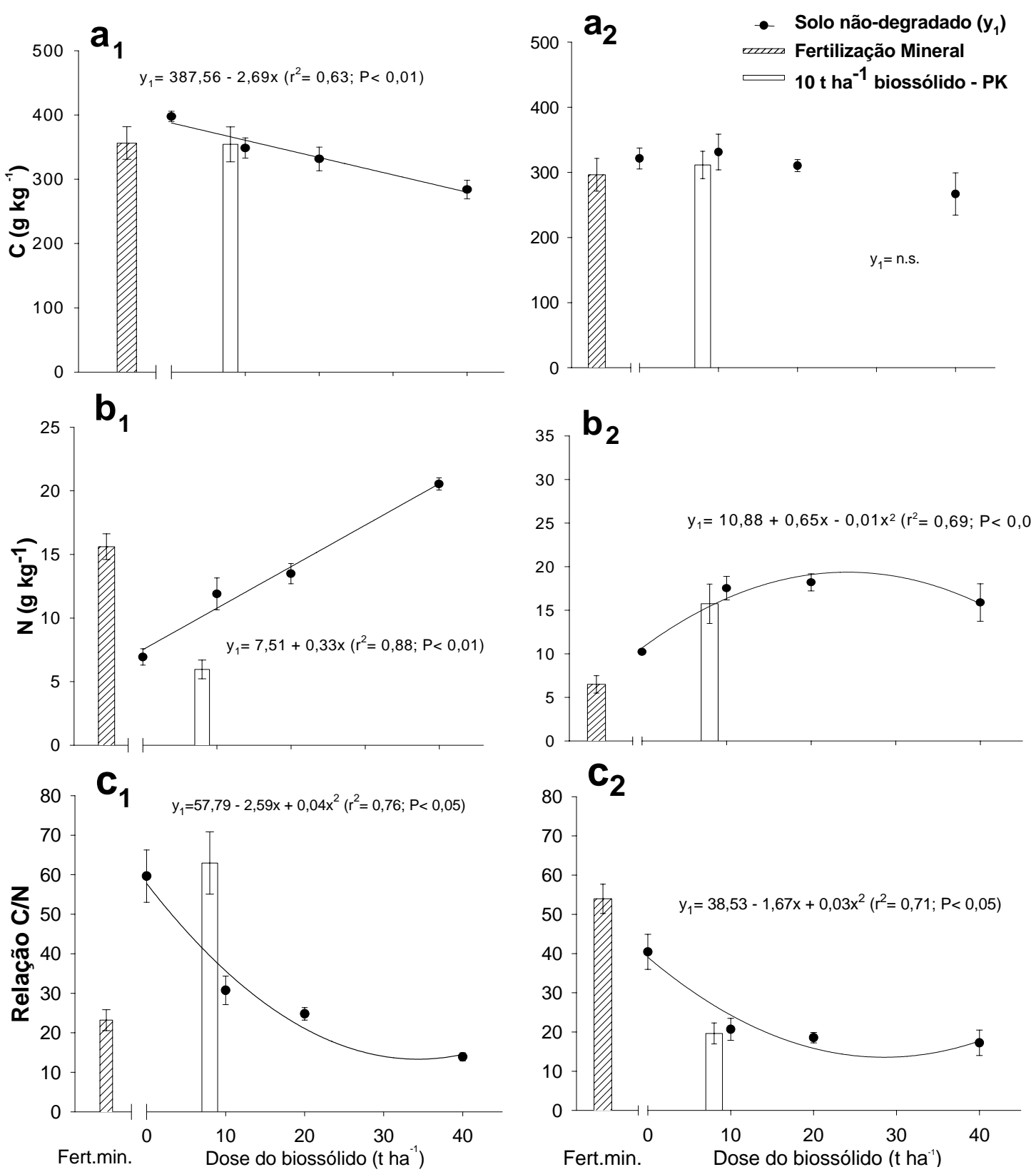

Figura 9- Concentrações de $\mathrm{C}$ total (a), de $\mathrm{N}$ total (b) e relação $\mathrm{C} / \mathrm{N}$ (c) (média \pm erro padrão) na serapilheira e serapilheira mais biossólido aos sete (1) e aos doze meses (2) pós-aplicação do biossólido, nos diferentes tratamentos (solo não-degradado) 


\subsubsection{Concentração de $\mathrm{N}$ mineral}

No tratamento Controle, as concentrações médias de $\mathrm{N}$ mineral variaram de 78 a $317 \mathrm{mg} \mathrm{kg}^{-1}$ (agosto de 2001 e março de 2002, respectivamente) (Figura 10), valores bem superiores aos encontrados por Gonçalves et al. (2000a), em plantio homogêneo de eucalipto em sistema de cultivo mínimo (4,6 a 41,3 $\mathrm{mg} \mathrm{kg}^{-1}$ ), embora concordantes com Adans \& Attiwill (1986) para diversas espécies de eucalipto e tipos de solo na Austrália. O aumento da concentração de $\mathrm{N}$ mineral ao longo do tempo, no tratamento Controle, está relacionado ao aumento da atividade microbiana, em resposta à maior umidade da serapilheira (aumento das chuvas) e temperatura do ar (Figuras $11 \mathrm{e}$ 12). 


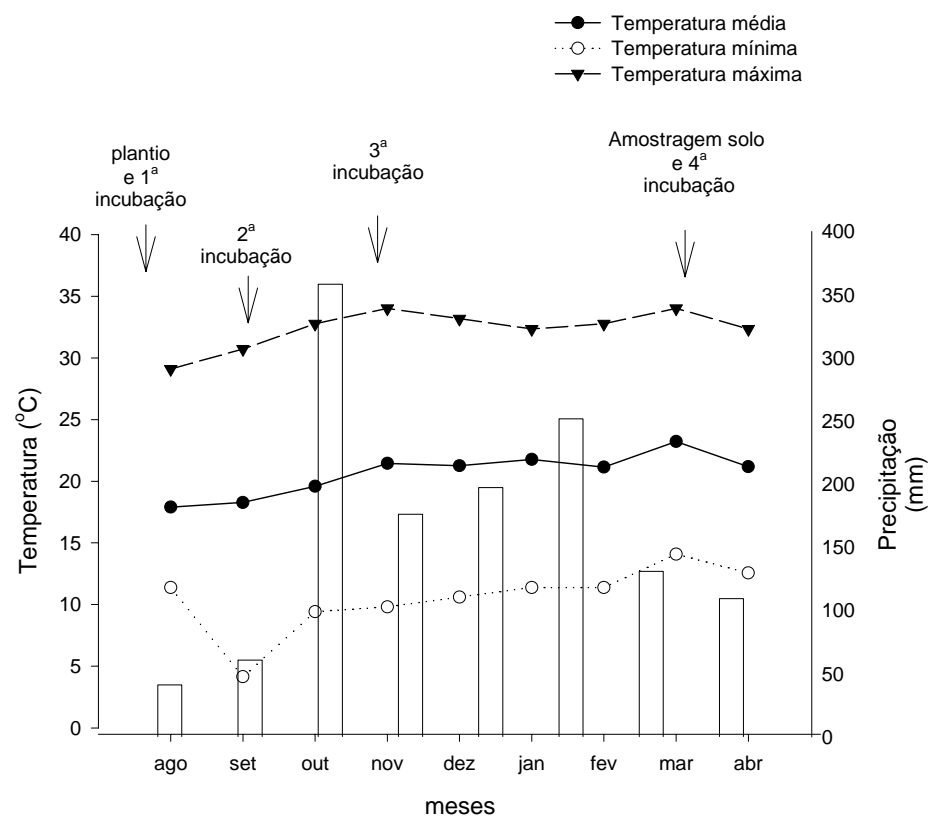

Figura 11- Precipitação, temperaturas média, máxima e mínima mensal durante os oito primeiros meses do experimento (agosto de 2001 a abril de 2002), com as indicações dos períodos de incubação do solo in situ em tubos de PVC
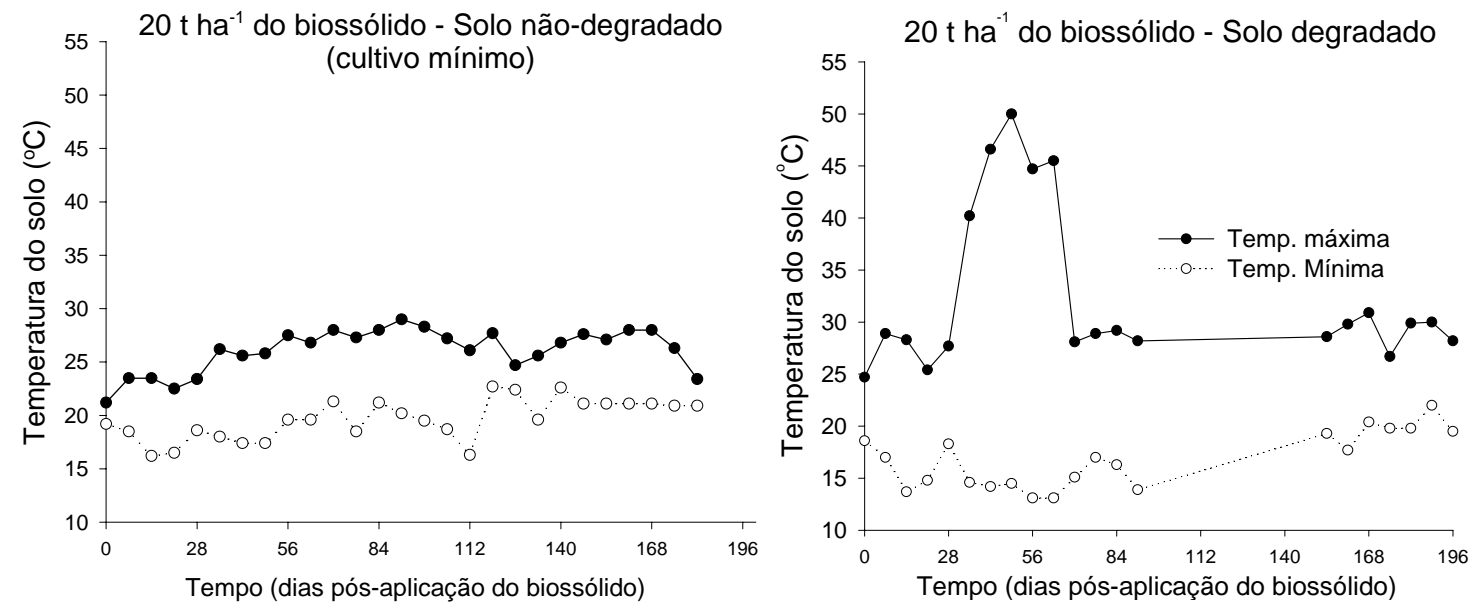

Figura 12- Temperaturas mínima e máxima do solo (a 5 cm de profundidade) não-degradado e degradado, durante os sete primeiros meses pós-aplicação do biossólido 
Os tratamentos que receberam biossólido tiveram concentrações de $\mathrm{N}$ mineral muito maiores $(\mathrm{P}<0,05)$ do que o Controle até 89 dias pós-aplicação do biossólido (valores máximos de $128 \mathrm{mg} \mathrm{kg}^{-1}$ na serapilheira, $3418 \mathrm{mg} \mathrm{kg}^{-1}$ na mistura serapilheira mais biossólido e $3600 \mathrm{mg} \mathrm{kg}^{-1}$ no biossólido puro sobre solo degradado) (Figura 10). Neste período também foram observadas as maiores perdas de $\mathrm{N}$ mineral dos resíduos sobre a superfície do solo em função do tempo. Nos três tratamentos avaliados (1, 4 e 8), a forma de $\mathrm{N}$ mineral predominante foi o $\mathrm{N}_{-} \mathrm{NH}_{4}{ }^{+}$, durante os primeiros sete meses $\mathrm{PAB}$. Assim, as formas das curvas de regressão obtidas para o $\mathrm{N}$ mineral total e o N-NH${ }_{4}^{+}$foram parecidas (Figura 10).

Para as concentrações de $\mathrm{N}-\mathrm{NH}_{4}{ }^{+}$, foram significativos os efeitos de tratamento, época e suas interações. A regressão para o fator época, bem como sua interação com tratamentos foram lineares ( $\mathrm{P}<0,05$ e 0,01 , respectivamente). Pelo ajuste do modelo de cinética de segunda ordem, observou-se comportamento similar nas perdas de $\mathrm{N}_{-} \mathrm{NH}_{4}{ }^{+}$nos dois tratamentos com biossólido $\left(20 \mathrm{t} \mathrm{ha}^{-1}\right)$, com diminuição mais acentuada deste íon nos primeiros meses PAB no solo degradado (Figura 13). Isso indicou uma maior capacidade de retenção de $\mathrm{N}_{-} \mathrm{NH}_{4}{ }^{+}$da mistura serapilheira mais biossólido, evidenciando uma fase inicial de imobilização deste nutriente na serapilheira (Figura 10), pela incorporação do $\mathrm{N}$ à biomassa microbiana, devido à grande quantidade de C disponível. Lerch et al. (1992) e Sierra et al. (2001) atribuíram a imobilizacão microbiana do $\mathrm{N}$ mineral oriundo do biossolido logo após sua aplicação no solo à presença de $\mathrm{C}$ lábil com alta relação $\mathrm{C} / \mathrm{N}$ no próprio biossólido, no entanto, no presente estudo, esta hipótese seria mais provável no biossólido sobre o solo degradado.

Aos 199 dias pós-aplicação, não houve diferenças estatísticas entre tratamentos, que apresentaram média de $350 \mathrm{mg} \mathrm{kg}^{-1}$ de $\mathrm{N}_{-\mathrm{NH}_{4}}^{+}$(Figura 13). Esta semelhança de concentrações (e, conseqüentemente, de $\mathrm{N}$ mineral) evidenciou a estabilização da mineralização do biossólido aos sete meses $\mathrm{PAB}$, mesmo em período de chuva intensa (março/2002). Prescott et al. (1993), em condições de laboratório, também observaram semelhança entre a disponibilidade de $\mathrm{N}$ mineral na serapilheira e na mistura serapilheira mais biossólido, das espécies florestais Pseudotsuga menziesii e Picea sitchensis, no décimo ano $\mathrm{PAB}$, fato atribuído à imobilização de $\mathrm{N}$ do biossólido no solo. 
As concentrações de $\mathrm{N}_{-} \mathrm{NO}_{3}{ }^{-}$na serapilheira, na mistura serapilheira mais biossólido e no biossólido puro foram bem menores do que as de $\mathrm{N}_{-} \mathrm{NH}_{4}^{+}(<1$ a $20 \%$ do $\mathrm{N}$ mineral total) (Figura 13). Elas apresentaram relação linear com o tempo e interação com tratamento $(\mathrm{P}<0,08$ e 0,01 , respectivamente). No tratamento Controle (somente

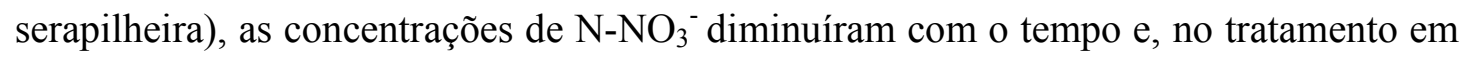
que houve a mistura de serapilheira mais biossólido, o aumento foi quadrático (Figura 13). Aos sete dias $\mathrm{PAB}$, as menores concentrações $(\mathrm{P}<0,05)$ de $\mathrm{N}_{-} \mathrm{NO}_{3}{ }^{-}$foram observadas no biossólido puro sobre o solo degradado $\left(1,2 \mathrm{mg} \mathrm{kg}^{-1}\right)$. A concentração de $\mathrm{N}-\mathrm{NO}_{3}{ }^{-}$no solo degradado aumentou a partir do vigésimo sexto dia, mantendo níveis constantes até o sétimo mês PAB (9,7-12,7 $\left.\mathrm{mg} \mathrm{kg}^{-1}\right)$. Diferentemente, a mistura serapilheira mais biossólido apresentou, no sétimo mês, concentração média de $\mathrm{N}^{-\mathrm{NO}_{3}}{ }^{-}$ 50 vezes superior ao tratamento controle $\left(48 \mathrm{mg} \mathrm{kg}^{-1}\right)$. Período de supressão da nitrificação (fase "lag") seguido de aumento da produção de nitrato, em biossólido, também foi observado por Ryan et al. (1973). No presente estudo, este resultado pode ser explicado pelas baixas concentrações de $\mathrm{N}^{-\mathrm{NO}_{3}}{ }^{-}$no biossólido, pela grande quantidade ${\mathrm{N}-\mathrm{NH}_{4}}^{+}$(Ryan et al., 1973; Smith et al., 1998; Insam \& Merschak, 1997), de sais (Low et al., 1997) e de metais pesados, potencialmente inibidores dos processos de nitrificação (Cela \& Sumner, 2002). Os padrões diferenciados de nitrificação ao longo do tempo, no solo degradado e não-degradado podem ainda ser explicados pelas condições físicas distintas à atividade microbiana (principalmente exposição do solo e aeração).

No solo degradado, foram observadas grandes oscilações em sua temperatura (Figura 12), desfavorecendo a atividade microbiana. A manutenção da serapilheira e da camada 0-20 cm propiciou, ao longo dos sete primeiros meses, menores oscilações de temperatura e umidade. As menores perdas de $\mathrm{N}$ mineral da mistura serapilheira mais biossólido no primeiro mês PAB (Figura 10) devem ter favorecido o aumento da população de nitrificadores autotróficos e heterotroficos, este último com ocorrência comum em solos sob florestas, com maior acidez (Van Miegroet \& Johnson, 1993). 

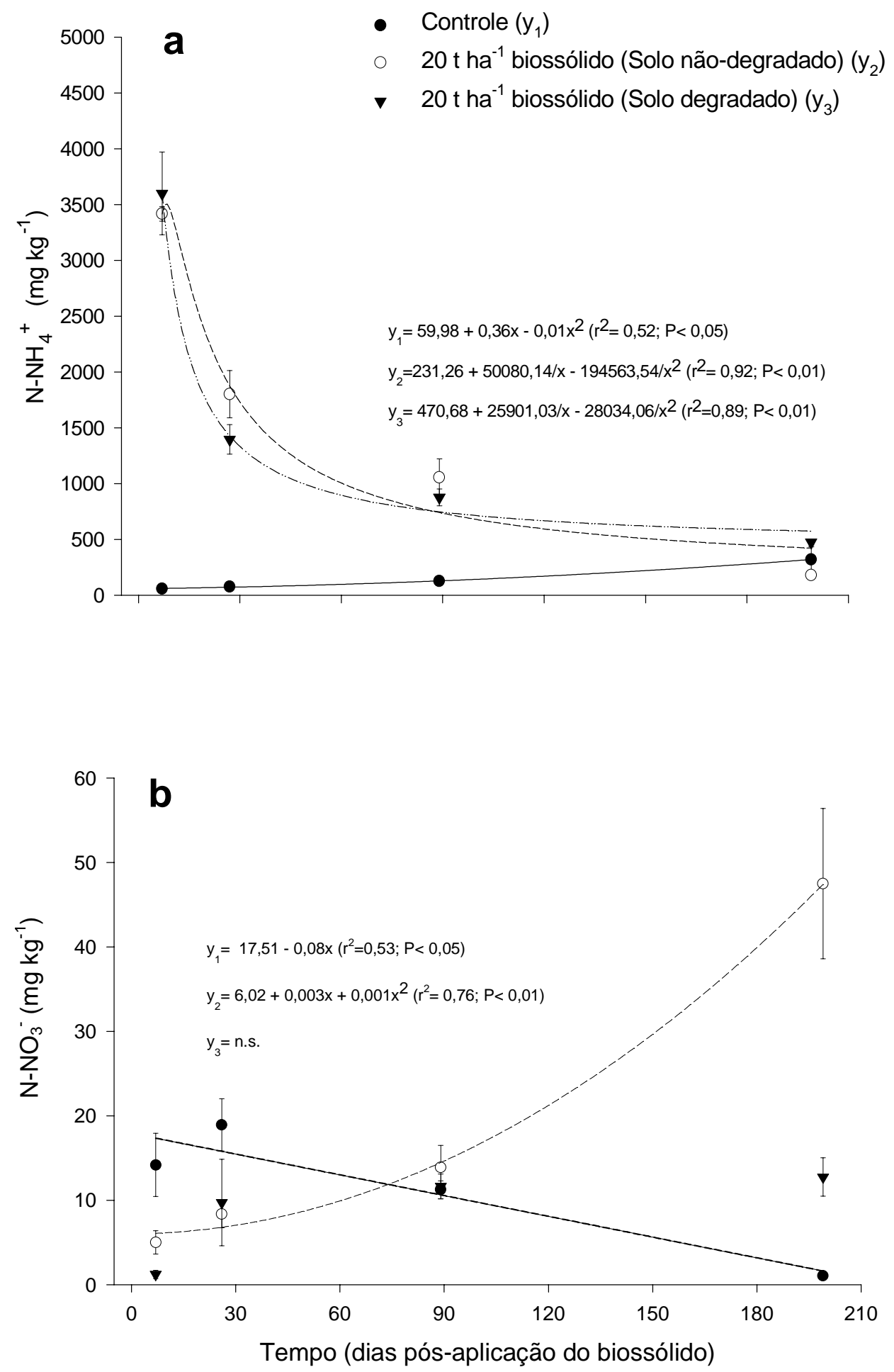

Figura 13- Concentração de $\mathrm{N}^{-\mathrm{NH}_{4}}{ }^{+}$(a) e $\mathrm{N}^{-1} \mathrm{NO}_{3}{ }^{-}$(b) (média \pm erro padrão) na serapilheira, na serapilheira mais biossólido $\left(20 \mathrm{t} \mathrm{ha}^{-1}\right)$ no solo não-degradado e no biossólido puro (20 $\left.\mathrm{t} \mathrm{ha}^{-1}\right)$ aplicado no solo degradado 


\subsubsection{Concentrações e conteúdos dos demais macronutrientes}

Em uma análise global, no período anterior à instalação do experimento, as concentrações e os conteúdos de nutrientes acumulados na serapilheira foram semelhantes e superiores, respectivamente, aos observadas por Kolm (2001) em cultivo de E. grandis (Tabelas 10 e 11). O grande conteúdo de nutrientes esteve relacionado à biomassa residual acumulada sobre o solo, constituída por resíduos depositados por culturas anteriores, pela vegetação do sub-bosque (triturada) e pela serragem produzida no processo de rebaixamento dos tocos de eucalipto.

A relação C/N da serapilheira $(49,1)$, antes da aplicação do biossólido, favoreceu a imobilização microbiana de parte dos nutrientes adicionada via biossólido, diminuindo a velocidade de mineralização da MO. Com a adição do biossólido e a alteração das concentrações de $\mathrm{C}$,de $\mathrm{N}$ totais e da relação $\mathrm{C} / \mathrm{N}$ ao longo do tempo (Figura 9), houve estímulo dos processos de mineralização da MO e transferência de nutrientes ao solo e às plantas (Tabelas 10 e 11) (Berg et al., 1998). Considerando o predomínio dos processos de imobilização líquida nos resíduos contendo menos que 12 $\mathrm{g} \mathrm{kg}^{-1}$ de $\mathrm{N}$ e $2 \mathrm{~g} \mathrm{~kg}^{-1}$ de $\mathrm{P}$, e mineralização líquida nos resíduos com concentrações de $\mathrm{N}$ e P superiores 18 e $3 \mathrm{~g} \mathrm{~kg}^{-1}$ (Gonçalves et al., 2002), nos tratamentos 1 e 2, aos sete e aos doze meses $\mathrm{PAB}$, ainda haveria o predomínio dos processos de imobilização de $\mathrm{N}$ e $\mathrm{P}$ na serapilheira. Os resultados são condizentes com Adans \& Attiwill (1986), ao afirmarem que a imobilização é o processo microbiano prevalente em florestas de eucalipto.

As concentrações dos macronutrientes na biomassa residual aumentaram linearmente com a aplicação do biossólido, aos sete meses PAB $(\mathrm{P}<0,05)$ (Tabela 10). Os conteúdos evidenciam o aumento da quantidade de nutrientes na mistura serapilheira mais biossólido, no entanto com transferências de nutrientes ao solo e,ou às plantas, em especial o K e o S (Tabela 11). Neste mesmo período, os conteúdos de macronutrientes contidos nos tratamentos que receberam 10 e $20 \mathrm{t} \mathrm{ha}^{-1}$ de biossólido mais suplementação de $\mathrm{P}$ e de $\mathrm{K}$ foram semelhantes, indicando estimulo diferenciado destas doses de biossólido à degradação da biomassa residual. 
O conteúdo de $\mathrm{P}$ na mistura serapilheira mais biossólido, em área total, diminuiu drasticamente entre sete e doze meses PAB, nos tratamentos com $10 \mathrm{tha}^{-1}$ de biossólido + PK (de $75 \pm 32$ para $\left.25 \pm 14 \mathrm{~kg} \mathrm{ha}^{-1}\right), 40 \mathrm{t} \mathrm{ha}^{-1}+\mathrm{PK}($ de $282 \pm 19$ para 117 $\left.\pm 65 \mathrm{~kg} \mathrm{ha}^{-1}\right)$ e $10 \mathrm{t} \mathrm{ha}^{-1}-\mathrm{PK}\left(\mathrm{de} 74 \pm 27\right.$ para $\left.39 \pm 17 \mathrm{~kg} \mathrm{ha}^{-1}\right)$ perdendo, para o solo e para as plantas, 47 a $66 \%$ de $\mathrm{P}$ (Tabela 11). Estas diminuições, em proporções diferentes, também foram observadas para o $\mathrm{Ca}, \mathrm{Mg}$ e $\mathrm{S}$. Os valores observados não confirmam os resultados obtidos por $\mathrm{Lu} \&$ O'Connor (2001), ao observarem que biossólidos contendo grandes concentrações de $\mathrm{Fe}$ e $\mathrm{Al}$ disponibilizam lentamente o $\mathrm{P}$, retendo-o por 1 a 3 anos pós-aplicação do biossólido. Os compostos Fe-P apresentam alta estabilidade a pH 5 (Rydin \& Otabbong, 1997) e, neste estudo, o pH da mistura serapilheira mais biossólido foi de 6,1 a 4,7 (inicio do experimento a sete meses PAB) (Tabela 9).

$\mathrm{O}$ conteúdo de $\mathrm{K}$ na serapilheira, pré-instalação do experimento, foi maior que o conteúdo aplicado via biossólido nos tratamentos com 10 e $20 \mathrm{t} \mathrm{ha}^{-1}$ (Tabela 11). Aos sete meses $\mathrm{PAB}$, o $\mathrm{K}$ presente na serapilheira, nos tratamentos 1 e 2 , foi diminuido a aproximadamente $1 / 4$ do valor inicial. O mesmo foi observado com a adição do biossólido, indicando que grande parte do $\mathrm{K}$ presente na serapilheira e no biossólido deve ter sido lixiviado logo após o início do período chuvoso (três meses após o plantio). A rápida mobilidade diminuiu as concentrações de $\mathrm{K}$ do solo em níveis abaixo do adequado para a nutrição das plantas, contribuindo para seu estresse nutricional (ver item fertilidade). Apesar das diminuições significativas de $\mathrm{K}$ no tratamento com $40 \mathrm{t} \mathrm{ha}^{-1}$ de biossólido, este ainda manteve os maiores níveis observados, em relação aos demais tratamentos.

As concentrações de $\mathrm{K}$ aumentaram aos doze meses $\mathrm{PAB}$, retornando a valores próximos ou maiores aos observados no período pré-plantio (Tabela 10). Este efeito também foi observado no tratamento com $10 \mathrm{t} \mathrm{ha}^{-1}$ de biossólido sem a suplementação de $\mathrm{P}$ e $\mathrm{K}$, porém em menor intensidade. Este aumento também foi observado para os conteúdos (Tabela 11), no entanto com valores próximos aos observados sete meses PAB. Além da suplementação potássica, ocorrida entre as duas amostragens (mês de agosto), as baixas temperatura e umidade podem ter favorecido a 
diminuição da atividade de microorganismos decompositores da serapilheira, ocasionando acúmulo de nutrientes. Além disso, neste período iniciou-se a queda de folhedo (ciclagem biogeoquímica), com o retorno de nutrientes das árvores para a superfície do solo, favorecendo o aumento das concentrações de K.

Tabela 10. Concentração de macronutrientes (média \pm desvio padrão) na serapilheira e na mistura serapilheira mais biossólido, antes da instalação do experimento, aos sete e aos doze meses pós-aplicação do biossólido (PAB), nos tratamentos em solo não-degradado

\begin{tabular}{|c|c|c|c|c|c|c|}
\hline \multirow[t]{5}{*}{ Tratamentos } & $\mathbf{P}$ & $\mathbf{K}$ & Ca & Mg & \multicolumn{2}{|l|}{ S } \\
\hline & \multicolumn{6}{|c|}{ Pré-instalação do experimento } \\
\hline & $0,2 \pm 0,0$ & $0,9 \pm 0,2$ & $7,2 \pm 0,8$ & $1,0 \pm 0,2$ & $0,6 \pm$ & 0,1 \\
\hline & \multicolumn{6}{|c|}{ Biossólido } \\
\hline & 25,4 & 1,0 & 25,3 & 4,3 & 13,6 & \\
\hline & \multicolumn{6}{|c|}{ Sete meses PAB } \\
\hline Controle & $0,4 \pm 0,1$ & $0,2 \pm 0,0$ & $7,7 \pm 2,1$ & $1,0 \pm 0,1$ & $0,8 \pm$ & 0,1 \\
\hline $10 \mathrm{tha}^{-1}+\mathrm{PK}$ & $5,5^{ \pm} 2,5$ & $0,3 \pm 0,1$ & $11,3 \pm 3,0$ & $2,0 \pm 0,6$ & $3,4^{ \pm}$ & 1,3 \\
\hline $20 \mathrm{tha}^{-1}+\mathrm{PK}$ & $7,0 \pm 0,9$ & $0,4^{ \pm} 0,0$ & $13,0 \pm 1,7$ & $2,3 \pm 0,3$ & $4,1^{ \pm}$ & 0,5 \\
\hline $40 \mathrm{tha}^{-1}+\mathrm{PK}$ & $11,4 \pm 0,7$ & $0,4 \pm 0,0$ & $18,4 \pm 1,1$ & $3,2 \pm 0,2$ & $7,0 \pm$ & 0,7 \\
\hline $\mathrm{P}$ (linear) & $<0,01$ & $<0,01$ & $<0,01$ & $<0,01$ & $<0,01$ & \\
\hline$r^{2}$ (linear) & 0,82 & 0,66 & 0,72 & 0,76 & 0,83 & \\
\hline $\mathrm{P}$ (quadrático) & n.s. & n.s. & n.s. & n.s. & n.s. & \\
\hline $\mathrm{r}^{2}$ (quadrático) & n.s. & n.s. & n.s. & n.s. & n.s. & \\
\hline Fert. Min. & $0,4^{ \pm} 0,2$ & $0,3 \pm 0,0$ & $10,1 \pm 3,0$ & $2,5 \pm 0,8$ & $0,8^{ \pm}$ & 0,1 \\
\hline \multirow[t]{2}{*}{$10 \mathrm{tha}^{-1}-\mathrm{PK}$} & $6,2 \pm 2,4$ & $0,4 \pm 0,0$ & $15,1 \pm 3,6$ & $2,0 \pm 0,6$ & $3,9^{ \pm}$ & 1,3 \\
\hline & \multicolumn{6}{|c|}{ Doze meses PAB } \\
\hline Controle & $0,3 \pm 0,1$ & $1,1 \pm 0,3$ & $11,3 \pm 0,3$ & $1,3 \pm 0,2$ & $1,2 \pm$ & 0,1 \\
\hline $10 \mathrm{tha}^{-1}+\mathrm{PK}$ & $5,1 \pm 3,1$ & $1,4 \pm 0,4$ & $14,7 \pm 2,4$ & $2,2 \pm 0,5$ & $3,4^{ \pm}$ & 1,4 \\
\hline $20 \mathrm{tha}^{-1}+\mathrm{PK}$ & $10,4^{ \pm} 1,4$ & $1,3 \pm 0,1$ & $19,5 \pm 1,9$ & $3,3 \pm 0,5$ & $5,9^{ \pm}$ & 0,6 \\
\hline $40 \mathrm{tha}^{-1}+\mathrm{PK}$ & $8,6^{ \pm} 4,8$ & $0,9 \pm 0,2$ & $18,0 \pm 4,2$ & $2,9 \pm 1,1$ & $4,8^{ \pm}$ & 1,9 \\
\hline P (linear) & $<0,05$ & n.s. & 0,05 & 0,05 & 0,01 & \\
\hline$r^{2}$ (linear) & 0,37 & n.s. & 0,36 & 0,33 & 0,37 & \\
\hline $\mathrm{P}$ (quadrático) & $<0,05$ & n.s. & n.s. & n.s. & $<0,05$ & \\
\hline $\mathrm{r}^{2}$ (quadrático) & 0,61 & n.s. & n.s. & n.s. & 0,64 & \\
\hline Fert. Min. & $0,2 \pm 0,2$ & $0,8^{ \pm} 0,3$ & $9,4 \pm 1,0$ & $1,5 \pm 0,2$ & $1,0^{ \pm}$ & 0,1 \\
\hline $10 \mathrm{tha}^{-1}-\mathrm{PK}$ & $4,6^{ \pm} 2,1$ & $0,6^{ \pm} 0,2$ & $12,6^{ \pm} 3,3$ & $1,7 \pm 0,5$ & $3,2 \pm$ & 1,1 \\
\hline
\end{tabular}


Tabela 11. Conteúdos de nutrientes na serapilheira e na mistura serapilheira mais biossólido (média \pm desvio padrão) acumulados na superfície do solo antes da instalação do experimento, aos sete e aos doze meses pós-aplicação do biossólido (PAB), nos tratamentos em solo nãodegradado

\begin{tabular}{|c|c|c|c|c|c|c|}
\hline Tratamento & $\mathbf{N}^{(1)}$ & $\mathbf{P}$ & $\mathbf{K}$ & Ca & Mg & $\mathbf{S}$ \\
\hline & & & $\mathrm{kgh}$ & & & \\
\hline \multirow{3}{*}{ Área total } & \multicolumn{6}{|c|}{ Pré-instalação do experimento } \\
\hline & $235,7 \pm 68,6$ & $7,7 \pm 1,5$ & $30,9 \pm 7,4$ & $248,5 \pm 33,1$ & $33,1 \pm 8,9$ & $21,7 \pm 4,2$ \\
\hline & \multicolumn{6}{|c|}{ Biossólido } \\
\hline $10 \mathrm{t} \mathrm{ha}^{-1}$ & 407 & 254 & 10 & 253 & 43 & 136 \\
\hline $20 \mathrm{t} \mathrm{ha}^{-1}$ & 814 & 508 & 20 & 506 & 86 & 272 \\
\hline \multirow[t]{2}{*}{$40 \mathrm{t} \mathrm{ha}^{-1}$} & 1628 & 1016 & 40 & 1012 & 172 & 544 \\
\hline & \multicolumn{6}{|c|}{ Sete meses PAB } \\
\hline Controle & $287,2 \pm 29,8$ & $14,9 \pm 3,7$ & $7,5 \pm 0,0$ & $287,2 \pm 78,3$ & $37,3 \pm 3,7$ & $29,8 \pm 3,7$ \\
\hline 10 tha $^{-1}+\mathrm{PK}^{(2)}$ & $344,7 \pm 60,0$ & $74,8 \pm 32,0$ & $8,5 \pm 1,2$ & $324,7 \pm 87,6$ & $48,4 \pm 9,6$ & $60,0 \pm 17,8$ \\
\hline 20 tha $^{-1}+\mathrm{PK}^{(2)}$ & $353,9 \pm 34,0$ & $85,8 \pm 12,2$ & $9,3 \pm 0,0$ & $332,3 \pm 70,6$ & $49,8 \pm 5,7$ & $64,3 \pm 7,9$ \\
\hline 40 tha $^{-1}+\mathrm{PK}^{(2)}$ & $696,7 \pm 48,5$ & $281,6 \pm 19,2$ & $14,5 \pm 0,0$ & $630,0 \pm 78,4$ & $101,1 \pm 7,3$ & $186,7 \pm 19,2$ \\
\hline Fert. Min. & $178,5 \pm 39,7$ & $11,3 \pm 5,7$ & $8,5 \pm 0,0$ & $286,1 \pm 85,0$ & $70,8 \pm 22,7$ & $22,7 \pm 2,8$ \\
\hline \multirow[t]{2}{*}{$10 \mathrm{tha}^{-1}-\mathrm{PK}^{(2)}$} & $343,2 \pm 49,8$ & $73,9 \pm 27,3$ & $9,1 \pm 0,0$ & $347,3 \pm 89,4$ & $45,5 \pm 8,7$ & $60,1 \pm 15,9$ \\
\hline & \multicolumn{6}{|c|}{ Dozes meses PAB } \\
\hline Controle & $81,1 \pm 5,0$ & $2,7 \pm 0,9$ & $9,0 \pm 2,6$ & $94,8 \pm 2,5$ & $10,7 \pm 2,1$ & $9,9 \pm 1,2$ \\
\hline 10 tha $^{-1}+\mathrm{PK}^{(2)}$ & $121,9 \pm 15,1$ & $25,1 \pm 14,0$ & $12,3 \pm 1,7$ & $129,9 \pm 10,9$ & $17,0 \pm 2,4$ & $22,1 \pm 6,6$ \\
\hline 20 tha $^{-1}+\mathrm{PK}^{(2)}$ & $199,2 \pm 10,3$ & $75,9 \pm 9,7$ & $14,9 \pm 0,8$ & $202,8 \pm 13,7$ & $30,8 \pm 3,4$ & $48,5 \pm 4,4$ \\
\hline 40 tha $^{-1}+\mathrm{PK}^{(2)}$ & $313,5 \pm 83,3$ & $117,5 \pm 65,3$ & $17,8 \pm 2,4$ & $306,0 \pm 56,7$ & $46,0 \pm 14,3$ & $71,9 \pm 26,2$ \\
\hline Fert. Min. & $109,1 \pm 11,1$ & $3,2 \pm 2,3$ & $10,9 \pm 4,4$ & $131,7 \pm 13,6$ & $21,1 \pm 2,6$ & $13,7 \pm 1,8$ \\
\hline $10 \mathrm{tha}^{-1}-\mathrm{PK}^{(2)}$ & $165,9 \pm 24,3$ & $38,8 \pm 16,9$ & $10,9 \pm 1,7$ & $165,5 \pm 27,0$ & $20,6 \pm 3,7$ & $32,4 \pm 8,7$ \\
\hline
\end{tabular}




\subsection{Fertilidade do Solo}

\subsubsection{Concentração de $\mathbf{N}$ mineral}

Nos sete primeiros meses $\mathrm{PAB}$, houve acúmulos e perdas de $\mathrm{N}$ mineral nos solos com biossólido $(0-30 \mathrm{~cm}$, tratamentos 4 e 8$)$ ao longo do tempo, principalmente na forma de $\mathrm{N}-\mathrm{NH}_{4}{ }^{+} \mathrm{e}$ na camada $0-10 \mathrm{~cm}$ (Figura 14). Esta transferência de $\mathrm{N}$ para as camadas subjacentes foi mais pronunciada no solo degradado nos primeiros dias PAB (agosto/2001), causada pelo contato direto do biossólido com a superfície do solo (resultado também confirmado pelas taxas de lixiviação). Em setembro, 26 dias $\mathrm{PAB}$, foram observadas maiores concentrações de $\mathrm{N}$ mineral no solo não-degradado com $20 \mathrm{t} \mathrm{ha}^{-1}$ de biossólido. Com a intensificação das chuvas (novembro), as concentrações de $\mathrm{N}$ mineral nas diferentes camadas dos solos que receberam biossólido (tratamentos 4 e 8 ) foram semelhantes, com tendência a maior transferência de $\mathrm{N}$ mineral no solo degradado (resultados também observados para as taxas de lixiviação de N). Em março, a camada $0-3 \mathrm{~cm}$ do tratamento com $20 \mathrm{t} \mathrm{ha}^{-1}$ do biossólido nãodegradado apresentou as maiores concentrações de $\mathrm{N}$ mineral, refletindo a liberação gradual do $\mathrm{N}$, durante os sete primeiros meses $\mathrm{PAB}$, da mistura serapilheira mais biossólido. No solo degradado, este efeito não foi observado, possivelmente devido à maior perda de $\mathrm{N}$ mineral nos primeiros meses $\mathrm{PAB}$ e, secundariamente, à menor nitrificação do $\mathrm{N}$ contido no biossólido. Abaixo de $10 \mathrm{~cm}$, ambos os tratamentos monitorados retornaram a concentrações semelhantes ao Controle (tratamento 1). 


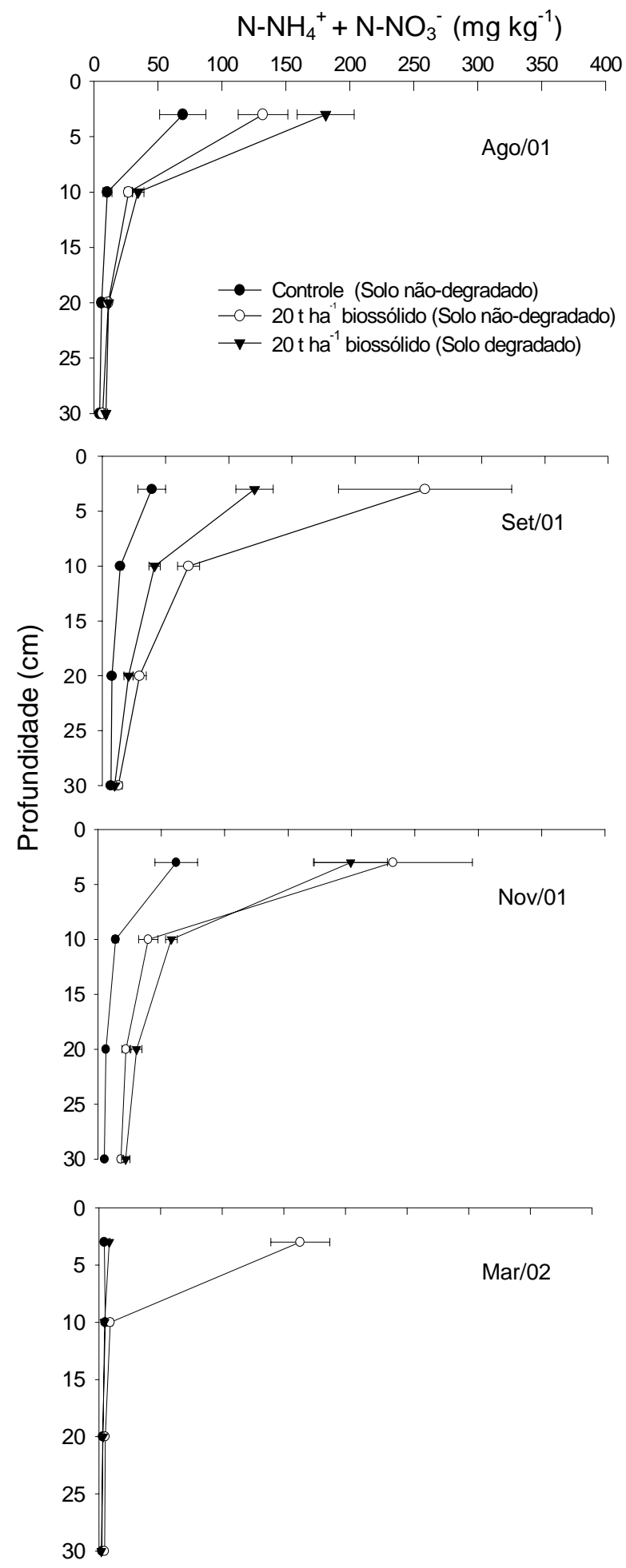

Figura 14- Distribuição de $\mathrm{N}$ mineral $\left(\mathrm{N}_{-} \mathrm{NH}_{4}{ }^{+}+\mathrm{N}-\mathrm{NO}_{3}{ }^{-}\right.$) (média \pm erro padrão) no perfil do solo (0-30 $\mathrm{cm}$ ), nos sete primeiros meses pós-aplicação do biossólido 


\subsubsection{Taxas de mineralização e de lixiviação de $\mathbf{N}$}

Com os valores obtidos, pôde-se deduzir algumas relações entre tratamentos, épocas de aplicação do biossólido e taxas de mineralização e de lixiviação de $\mathrm{N}$ no solo. Observou-se que a variabilidade dos dados foi pequena no Controle e grande nos tratamentos que receberam biossólido (Figuras 15 a 18). Segundo Whynot \& Weetmam (1991), isso se deveu à variabilidade espacial do solo e da irregularidade de aplicação e da mineralização do biossólido. Apesar dos desvios esperados, pôde-se detectar comportamentos distintos do $\mathrm{N}$ no solo, em uma mesma dose de biossólido, em solo submetido ou não à degradação.

\subsubsection{Mineralização de N}

Pela análise de variância, constatou-se alta significância entre as taxas de mineralização de $\mathrm{N}$ mineral total e as diferentes épocas de análise $(\mathrm{P}<0,01)$. Pôde-se realizar o desdobramento das curvas de regressão para os três tratamentos, ajustando-se modelos polinomiais inversos de segunda e de terceira ordem (Figura 15).

$\mathrm{Na}$ fase inicial do experimento, no Controle (tratamento 1), foram observadas altas taxas de mineralização de $\mathrm{N}$ na camada $0-30 \mathrm{~cm}$ do solo $\left(47 \pm 4 \mathrm{~kg} \mathrm{ha}^{-1}\right.$ mês ${ }^{-1}$ de $\mathrm{N}$ e $40 \pm 2 \mathrm{~kg} \mathrm{ha}^{-1}$ mês $^{-1}$ de $\mathrm{N}$ aos 26 e 40 dias pós-aplicação, respectivamente) (19 e 33 dias pós-primeira incubação do solo - PPI) (Figura 15). Estes valores foram muito superiores às quantidades de $\mathrm{N}$ mineralizadas obtidas por Gonçalves et al. (2001), Wang et al. (1998) e Moroni et al. (2002), com uso dos mesmos métodos de amostragem. Em seis meses, Gonçalves et al. (2001) obtiveram, em plantio de E. grandis com sete anos de idade sobre Latossolo Vermelho-Amarelo textura média (camada 0-30 cm), mineralização de $41 \mathrm{~kg} \mathrm{ha}^{-1}$ de N; Wang et al. (1998) e Moroni et al. (2002), em plantios de 1 a 2 anos e de 1 a 4 anos, respectivamente, de E. nitens sobre Latossolo, na camada $0-10 \mathrm{~cm}$ do solo, obtiveram mineralização de 18 a $91 \mathrm{~kg} \mathrm{ha}^{-1}$ ano $^{-1}$ e 13 a $188 \mathrm{~kg} \mathrm{ha}^{-1}$ ano $^{-1}$, respectivamente. Além da grande quantidade de resíduos vegetais presentes sobre o solo, os grandes valores de $\mathrm{N}$ mineral devem estar 
relacionados a mineralização de raízes mortas e ao aumento da temperatura e umidade do solo, causado pela remoção do povoamento florestal e da vegetação do sub-bosque (herbácea), antes da instalação do experimento. 
Durante todo o período avaliado, a comparação entre médias por Tukey $(\mathrm{P}<0,05)$, em cada época, não indicou diferenças significativas entre os teores de $\mathrm{N}$ mineral do Controle (1) e dos demais tratamentos, devido à alta variabilidade de dados. No entanto, foram obtidos modelos polinomiais inversos de segunda e de terceira ordem, relacionando taxas e épocas $(\mathrm{P}<0,01)$ (Figura 15). Nos solos com biossólido, houve grande aumento das taxas de mineralização de $\mathrm{N}$ aos trinta e três dias PPI (quarenta dias $\mathrm{PAB}$ ), com valor máximo de $103 \pm 36 \mathrm{~kg} \mathrm{ha}^{-1}$ mês $^{-1}$ (Figura 15). Parte do N considerado como mineralizado pode ter sido transferido do biossólido para o solo, devido à grande quantidade de $\mathrm{N}$ mineral e umidade do biossólido. Esta hipótese é reforçada pela transferëncia de N mineral do biossólido para o solo no primeiro mës PAB (Figura 14). Após este período de grandes concentrações de $\mathrm{N}$ mineral (Figuras 14 e 15), as taxas decresceram a valores próximos aos observados no Controle, aos sete meses PAB. Tendo em vista a equação de regressão, o tratamento com a mistura de serapilheira mais biossólido apresentou as maiores taxas de mineralização de $\mathrm{N}$ ao longo do tempo, com diminuição menos abrupta em relação ao solo degradado. Além das oscilações bruscas de temperatura e umidade (Figura 12), a diminuição da porosidade pode estar restringindo a mineralização do solo degradado (Gonçalves \& Carlyle, 1994), por oferecer maior proteção física da $\mathrm{MO}$ do solo ao ataque dos microorganismos (Breland \& Hansen, 1996; De Neve \& Hofman, 2000).

As taxas de amonificação também apresentaram relação com as diferentes épocas e os tratamentos $(\mathrm{P}<0,05)$, obtendo-se, a partir do desdobramento da regressão, modelos polinomiais inversos de primeira a terceira ordem para os tratamentos avaliados $(\mathrm{P}<0,05)$ (Figura 16a). No mês de agosto, para os três tratamentos, a taxa de amonificação média foi de $38 \mathrm{~kg} \mathrm{ha}^{-1}$ mês $^{-1}$ (Figura 16a). Nos dois tratamentos que receberam biossólido, houve rápido aumento das taxas de amonificação do solo, dos 19 aos 33 dias PPI (26 a 40 dias PAB), possivelmente devido à transferência de $\mathrm{N}_{-} \mathrm{NH}_{4}{ }^{+}$ do biossólido ao solo. Em novembro, a taxa média de amonificação no solo degradado tornou-se semelhante ao valor médio obtido no solo Controle. Este resultado pode ter relação com a menor concentração de $\mathrm{MO}$ no solo degradado e com as rápidas perdas de $\mathrm{N}$ mineral do biossólido no primeiro mês pós-aplicação (Figuras 14). Nos dois 
tratamentos ( 1 e 8), houve predomínio de processos de imobilização do $\mathrm{N}_{-} \mathrm{NH}_{4}{ }^{+}$aos 96 dias PPI (-6,36 $\pm 4,1$ e $-5,5 \pm 36,0 \mathrm{~kg} \mathrm{ha}^{-1} \mathrm{mês}^{-1}$ de N-NH${ }_{4}^{+}$no tratamento Controle e solo degradado, respectivamente). O grande erro padrão observado no segundo caso pode estar relacionado à transferência de MO lábil do biossólido ao solo, interferindo nas taxas de mineralização de N. O solo não-degradado com biossólido também apresentou diminuição das taxas de amonificação com o tempo, mas manteve taxas maiores aos demais tratamentos, até o mês de novembro, quando prevaleceram os processos de imobilização de N nos três tratamentos avaliados (Figura 16a).

Com a aplicação do biossólido, portanto, os modelos que explicam as taxas de mineralização de $\mathrm{N}$ mineral e de amonificação no solo evidenciam a existência de diferentes frações de $\mathrm{N}$ potencialmente mineralizáveis: a primeira lábil, formada por substâncias orgânicas mais facilmente degradáveis que restaram do tratamento biológico do biossólido (proteínas bacterianas, carboidratos e frações orgânicas de $\mathrm{N}$ de baixo peso molecular), e as demais recalcitrantes (de decomposição lenta) (Terry et al., 1979a; Terry et al., 1979b; Lerch et al, 1992; Oliveira, 2000; Benbi \& Richter, 2002).

Para a nitrificação, foram significativos o efeito de tratamento e a interação quadrática entre tratamento e época $(\mathrm{P}=0,05)$. As concentrações de $\mathrm{N}_{-} \mathrm{NO}_{3}{ }^{-}$, em todas as épocas de amostragem, foram altas, com taxas médias de 26,2, 28,6 e 18,4 $\mathrm{kg} \mathrm{ha}{ }^{-1}$ mês $^{-1}$ de $\mathrm{N}^{-N_{3}}{ }^{-}$para o tratamento Controle, no solo não-degradado e degradado, respectivamente (Figura 16b). O solo não-degradado apresentou maiores taxas de nitrificação em relação ao solo degradado durante todo o período avaliado $(\mathrm{P}<0,05)$. Apenas para o solo degradado pôde-se ajustar uma regressão quadrática $(\mathrm{P}<0,01)$; neste, as taxas de nitrificação aumentaram até os 96 dias PPI, e depois diminuíram. Além da menor nitrificação do biossólido puro aplicado na superfície do solo degradado (Figura 13), as menores taxas de nitrificação e lixiviação de $\mathrm{N}_{-} \mathrm{NO}_{3}{ }^{-}$no solo também podem estar relacionadas à diminuição da porosidade do solo, como explicado para o N-NH${ }_{4}^{+}$(Breland \& Hansen, 1996; De Neve \& Hofman, 2000). 

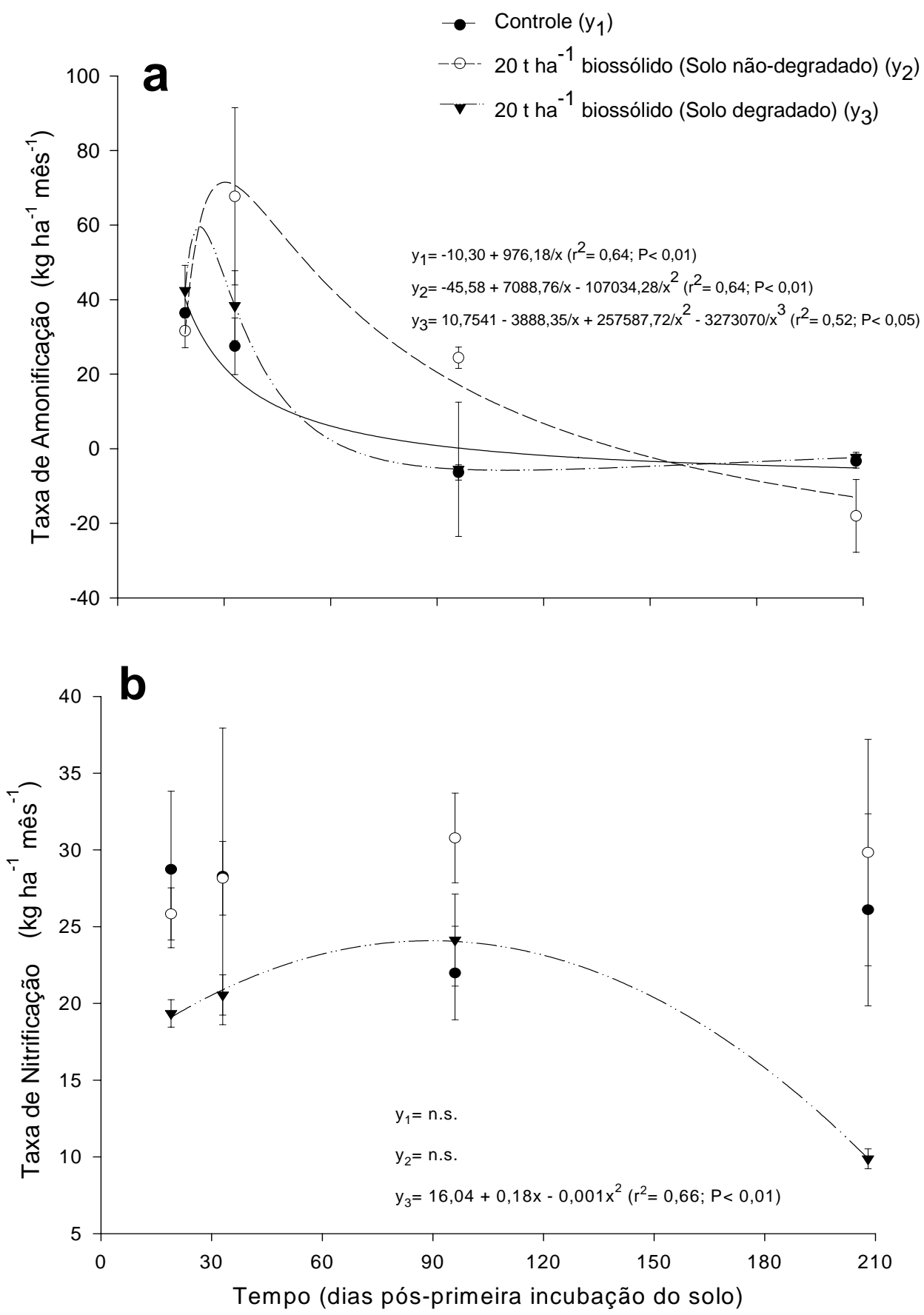

Figura 16- Taxas de amonificação (a) e de nitrificação (b) na camada 0-30 cm (média \pm erro padrão) do solo não-degradado, sem e com aplicação de $20 \mathrm{t} \mathrm{ha}^{-1}$ do biossólido, e do solo degradado que recebeu $20 \mathrm{t} \mathrm{ha}^{-1}$ do biossólido 


\subsubsection{Lixiviação de $\mathrm{N}$}

As taxas de lixiviação de $\mathrm{N}$ mineral na camada $0-30 \mathrm{~cm}$ do solo apresentaram relação cúbica com todos os fatores analisados (tratamentos, épocas e suas interações) $(\mathrm{P}<0,05)$. O Controle teve como balanço de $\mathrm{N}$ mineral valores médios positivos em todas as épocas de amostragem, indicando perdas de $\mathrm{N}$ mineral, da camada 0-30 cm do solo, em todo o período amostrado (Figura 17). De modo geral, as taxas de lixiviação foram maiores do que as observadas por Gonçalves et al. (2000a) (em seis meses, lixiviação de $31,7 \mathrm{~kg} \mathrm{ha}^{-1}$ de $\mathrm{N}$, na camada 0-30 cm), Wang et al. (1998) e Moroni et al. (2002) (em seis meses, lixiviação de 64 e $79 \mathrm{~kg} \mathrm{ha}^{-1}$, respectivamente, na camada $0-10 \mathrm{~cm}$ ), todos com o uso do mesmo método. No entanto, no presente estudo, também foram maiores as taxas de mineralização de $\mathrm{N}$ do solo (item 4.3.2.1). $\mathrm{O}$ solo não-degradado que recebeu biossólido apresentou aumento nos conteúdos de $\mathrm{N}$ mineral total durante o primeiro período de incubação (agosto/2001) (ou seja, acúmulo, valores negativos) (Figura 17), mas, nos meses subseqüentes, predominou a lixiviação de N (valores positivos). Contudo, no solo degradado houve o predomínio do aumento dos conteúdos de $\mathrm{N}$ na camada $0-30 \mathrm{~cm}$ em todos os meses, ou seja, o acúmulo de $\mathrm{N}$ mineral nesta camada do solo foi maior do que as perdas por lixiviação.

O tratamento e a época de amostragem afetaram as taxas de lixiviação de $\mathrm{N}^{-\mathrm{NH}_{4}}{ }^{+}$(Figura 18). O desdobramento da regressão indicou efeito linear para o fator época $(\mathrm{P}<0,05)$ e cúbico para interação entre época e tratamento $(\mathrm{P}<0,05)$. No entanto, obteve-se um ajuste do modelo apenas para o solo degradado $(\mathrm{P}<0,01)$ (Figura 18).

Durante todo o período amostrado, houve lixiviação de $\mathrm{N}_{-} \mathrm{NH}_{4}{ }^{+}(0-30$ $\mathrm{cm}$ ) no Controle, variando de 13 (agosto) a $25 \mathrm{~kg} \mathrm{ha}^{-1}$ (setembro) - (Figura 18). O solo não-degradado, nos tratamentos que receberam biossólido, aos dezenove dias PPI (26 dias PAB), apresentou valores negativos (-26 $\pm 11 \mathrm{~kg} \mathrm{ha}^{-1}$ mês $\left.^{-1}\right)$, indicando acúmulo de $\mathrm{N}-\mathrm{NH}_{4}{ }^{+}$nesta camada. No período subseqüente, houve oscilação entre perdas e acúmulo, e pequena variação a partir do terceiro mês $\mathrm{PAB}$, com a intensificação das chuvas.

No solo degradado, ficou mais evidente o acúmulo de $\mathrm{N}_{-} \mathrm{NH}_{4}{ }^{+}$nos três primeiros meses PAB (Figura 18). O valor máximo, entre todos os tratamentos, ocorreu 
no solo degradado aos 33 dias PPI, diferindo dos demais tratamentos pelo teste de Tukey a $\mathrm{P}<0,05\left(-107 \pm 38 \mathrm{~kg} \mathrm{ha}^{-1}\right.$ mês $\left.{ }^{-1}\right)$ e indicando intenso acúmulo de $\mathrm{N}-\mathrm{NH}_{4}{ }^{+}$oriundo do biossólido. A menor porosidade do solo, a pouca chuva no mês de setembro, o maior $\mathrm{pH}$ do solo e a grande concentração de MO podem estar favorecendo o maior acúmulo deste íon no solo, devido ao baixo fluxo de solução e à retenção de $\mathrm{N}^{-\mathrm{NH}_{4}}{ }^{+}$(Suprayogo et al., 2002). De acordo com a equação ajustada para o solo degradado (com biossólido), exceto aos sete meses $\mathrm{PAB}$, o acúmulo de $\mathrm{N}_{-} \mathrm{NH}_{4}{ }^{+}$na camada $0-30 \mathrm{~cm}$ foi maior que a lixiviação, resultando em balanço negativo. Desta forma, não foi possível estimar com acuidade as perdas de $\mathrm{N}-\mathrm{NH}_{4}{ }^{+}$na camada $0-30 \mathrm{~cm}$ do solo.

A época, o tratamento e a interação entre estas variáveis influenciaram a lixiviação de $\mathrm{N}_{-} \mathrm{NO}_{3}{ }^{-}$. O efeito foi cúbico para época $(\mathrm{P}<0,01)$ e a interação entre época e tratamento foi linear $(\mathrm{P}<0,01)$ (Figura 18). Nos três tratamentos, as menores perdas ocorreram no primeiro período de incubação (média dos três tratamentos: $3,9 \mathrm{~kg} \mathrm{ha}^{-1}$ mês $^{-1}$ ), quando os processos de nitrificação e lixiviação estiveram limitados pelas baixas temperaturas e umidade no solo. No segundo período de incubação, observou-se aumento das taxas de lixiviação do $\mathrm{N}^{-\mathrm{NO}_{3}}{ }^{-}$(média dos três tratamentos: $20,4 \pm 3,9 \mathrm{~kg}$ $\left.\mathrm{ha}^{-1} \mathrm{mês}^{-1}\right)$. Apesar das menores médias observadas no solo degradado, apenas em março estas foram significativamente diferentes $(\mathrm{P}<0,05)$ dos demais tratamentos (solo degradado com biossólido $=16,8 \pm 9,0 \mathrm{~kg} \mathrm{ha}^{-1}$ mês $^{-1}$; tratamento Controle $=25,3 \pm 10,0$ $\mathrm{kg} \mathrm{ha}^{-1}$ mês $^{-1}$; solo não-degradado com biossólido $\left.=31,79 \pm 11,0\right)$. Apesar da alta lixiviação de $\mathrm{N}^{-} \mathrm{NO}_{3}{ }^{-}$ao longo do tempo, é provável que ela seja menor em camadas subjacentes, devido à maior eletronegatividade destas (Eick et al., 1999). 


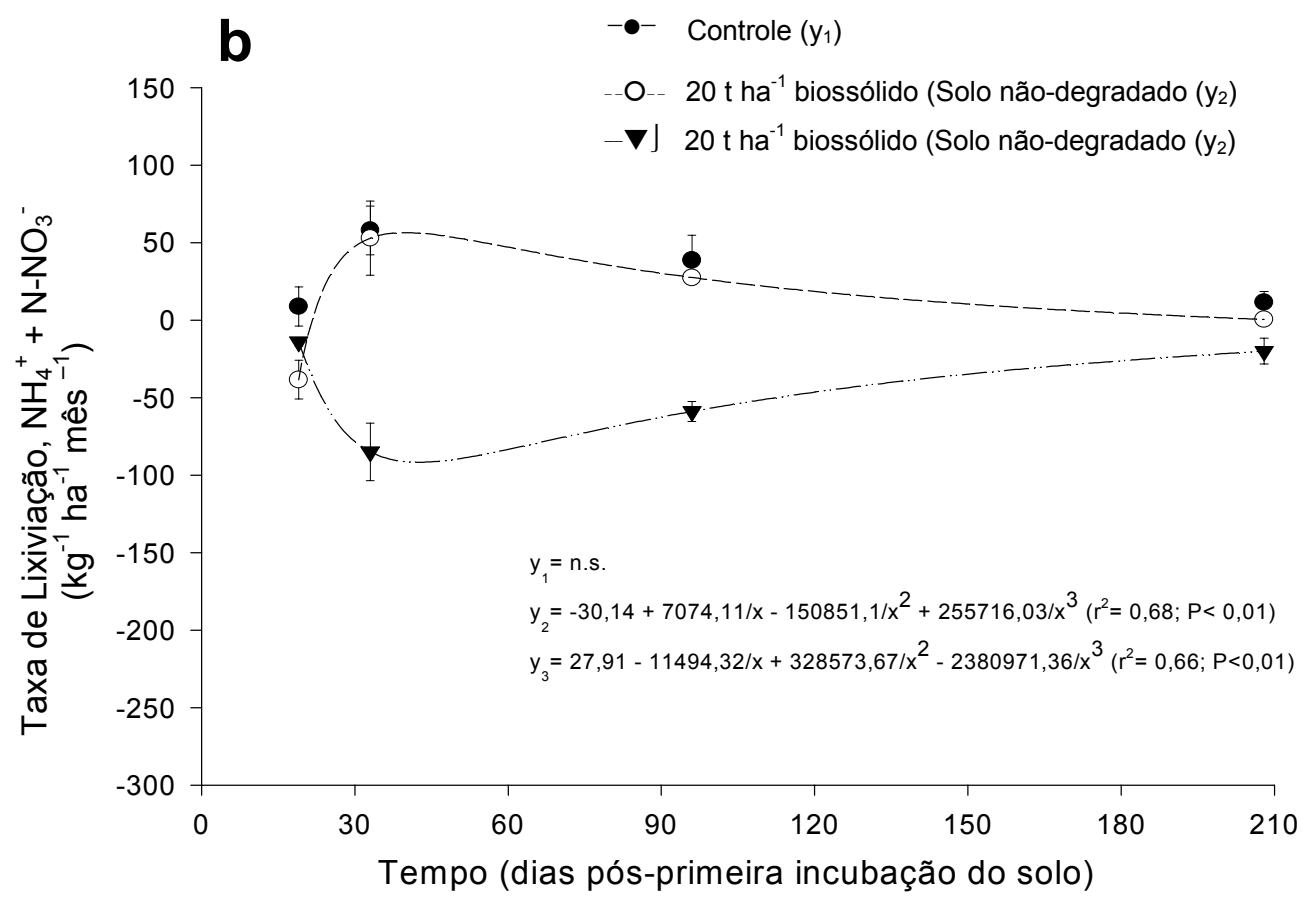

Figura 17- Taxa de lixiviação de $\mathrm{N}$ mineral total $\left(\mathrm{N}^{-} \mathrm{NH}_{4}{ }^{+}+\mathrm{N}^{-\mathrm{NO}_{3}}{ }^{-}\right)$na camada $0-30 \mathrm{~cm}$ (média \pm erro padrão) do solo não-degradado, sem e com aplicação de $20 \mathrm{t} \mathrm{ha}^{-1}$ do biossólido, e do solo degradado que recebeu $20 \mathrm{t}_{\text {ha }}{ }^{-1}$ do biossólido 

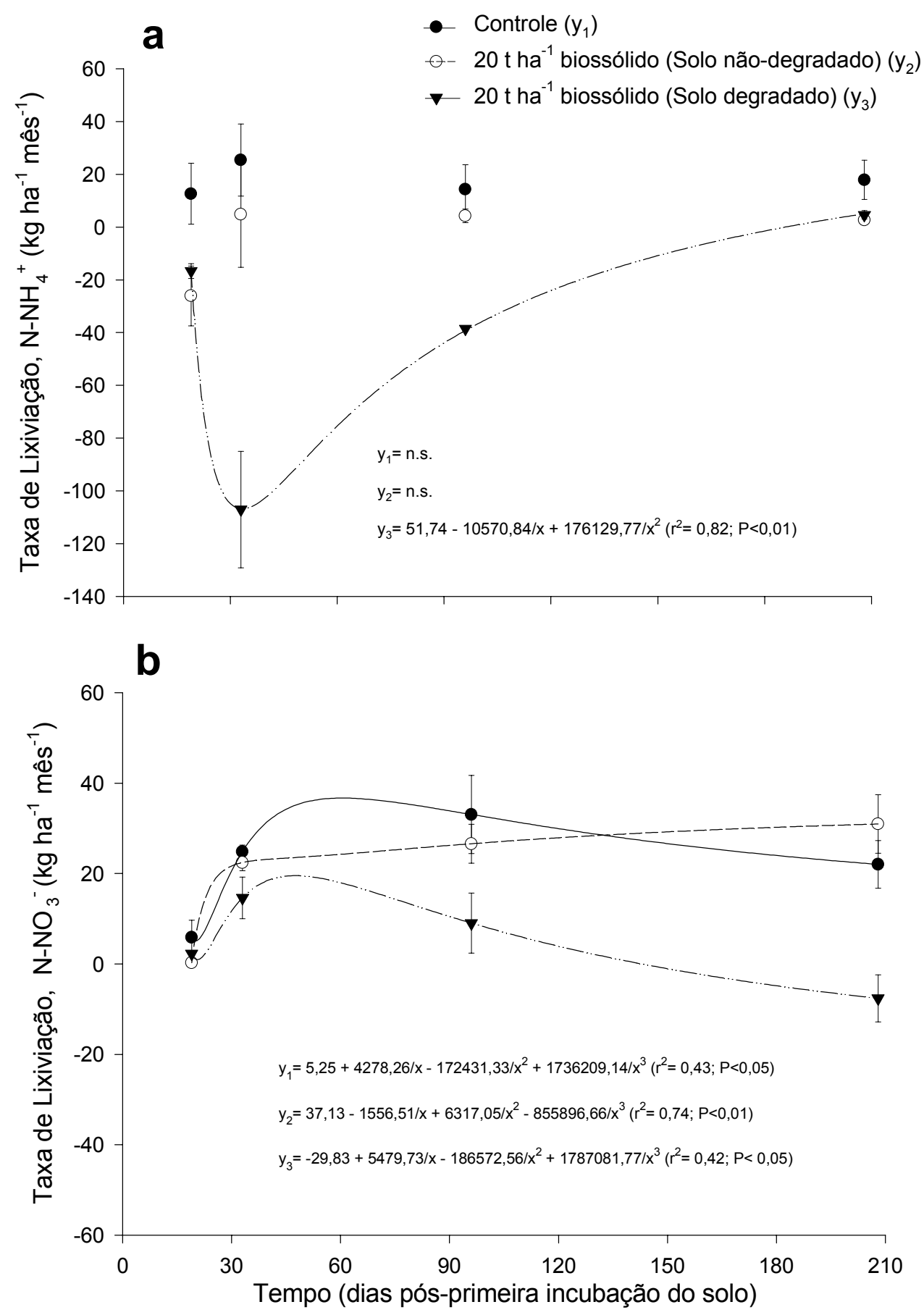

Figura 18- Taxas de lixiviação de $\mathrm{N}^{-\mathrm{NH}_{4}}{ }^{+}$(a) e $\mathrm{N}^{-\mathrm{NO}_{3}}{ }^{-}$(b) na camada 0-30 $\mathrm{cm}$ (média \pm erro padrão) do solo não-degradado, sem e com aplicação de $20 \mathrm{t} \mathrm{ha}^{-1}$ do biossólido, e do solo degradado que recebeu $20 \mathrm{tha}^{-1}$ do biossólido 


\subsubsection{Modelagem da mineralização e da lixiviação de N}

A mineralização de $\mathrm{N}$, estimadas pelas equações apresentadas na Figura 15, em sete meses PPI, foi de $182 \mathrm{~kg} \mathrm{ha}^{-1}$ no solo sob tratamento Controle, $609 \mathrm{~kg} \mathrm{ha}^{-1}$ de $\mathrm{N}$ no solo não-degradado (com biossólido), e $729 \mathrm{~kg} \mathrm{ha}^{-1}$ de $\mathrm{N}$ no solo degradado (com biossólido) (Tabela 12). Nos solos com aplicação de biossólido, grande parte desta quantia teria sido mineralizada no primeiro mês pós-aplicação do biossólido (54 e 82\% do $\mathrm{N}$ mineralizado em sete meses PPI, respectivamente, estimados pelas equações). No entanto, os dados estão superestimados em decorrência da intensa transferência de N$\mathrm{NH}_{4}{ }^{+}$do biossólido ao solo no primeiro mês de avaliação. Isto deve ter ocorrido mesmo com os tubos fechados, devido à alta umidade do biossólido. Dessa forma, desconsiderando-se os resultados estimados para 30 dias PPI, com a aplicação de biossólido no solo não-degradado, a mineralização de $\mathrm{N}$ do solo passou de $5 \%$ (Controle, 125 a $128 \mathrm{~kg} \mathrm{ha}^{-1}$ de N) para $10 \%\left(278 \mathrm{~kg} \mathrm{ha}^{-1}\right.$ de N) do $\mathrm{N}$ mineral total do solo, em seis meses. A intensificação da decomposição do $\mathrm{N}$ orgânico do solo após a aplicação de biossólido também foi observada por Linderman \& Cardenas (1984). No solo degradado, obteve-se $6 \%$ de mineralização do $\mathrm{N}$ orgânico total do solo (130 kg ha ${ }^{1}$ ), valor próximo ao observado no solo não-degradado sem aplicação de biossólido. Estes valores são relativamente altos, pois Gonçalves et al. (2001) verificaram que, em média, $10 \%$ do $\mathrm{N}$ orgânico dos solos mais usados em florestamentos, no estado de São Paulo, são mineralizáveis em longo prazo. Além disso, são quantidades muito maiores do que as demandas anuais de povoamentos de eucalipto (20 a $40 \mathrm{~kg} \mathrm{ha}^{-1} \mathrm{ano}^{-1}$ ) (Bellote et al., 1980; Reis et al., 1987; Poggiani \& Schumaker, 1997).

A quantidade média de $\mathrm{N}$ lixiviada do solo $(0-30 \mathrm{~cm})$ não-degradado, sem aplicação de biossólido (170 $\left.\mathrm{kg} \mathrm{ha}^{-1}\right)$ em sete meses PPI foi semelhante à quantidade mineralizada (Tabela 12). Provavelmente, esta grande quantidade de $\mathrm{N}$ mineralizado e lixiviado seja devido ao aporte de $\mathrm{N}$ mineralizado na serapilheira e outros resíduos vegetais (sobras da colheita florestal), o aumento da temperatura e umidade do solo, causado pela remoção do povoamento florestal e da vegetação do sub-bosque (herbácea) e da decomposição de raízes (item 4.3.2.1 e 4.3.2.2). Com a aplicação de 
biossólido no solo não-degradado, por meio da equação relativa às taxas de lixiviação, verificou-se que a perda de $\mathrm{N}$, aos sete meses PPI, foi inferior ao Controle (158 $\mathrm{kg} \mathrm{ha}^{-1}$ de $\mathrm{N}$ ). Estes valores podem estar subestimados, devido ao alto acúmulo de $\mathrm{N}$ mineral na camada 0-30 cm, em especial de $\mathrm{N}^{-N_{4}}{ }_{4}$, como observado pelo aumento das concentrações. Contudo, de acordo com os modelos, as quantidades lixiviadas foram bem menores às do solo degradado com biossólido, evidenciando a inicial imobilização mecânica e microbiológica de $\mathrm{N}$ pela serapilheira.

Tabela 12. Taxas mensais de mineralização e de lixiviação de $\mathrm{N}$, e quantidades totais de $\mathrm{N}$ mineralizado e lixiviado nos sete primeiros meses pós-primeira incubação (PPI) do solo, na camada 0-30 cm, obtidas pelas equações de regressão, em diferentes tratamentos

\begin{tabular}{|c|c|c|c|c|c|c|c|c|c|c|}
\hline \multirow{3}{*}{ Tempo } & \multicolumn{6}{|c|}{ N Mineralizado } & \multicolumn{4}{|c|}{ N Lixiviado } \\
\hline & \multicolumn{2}{|c|}{ Controle $^{(1)}$} & \multicolumn{2}{|c|}{$\begin{array}{l}20 \text { t ha }^{-1} \text { bios. } \\
\text { Solo não-degr. }\end{array}$} & \multicolumn{2}{|c|}{$\begin{array}{l}20 \text { t ha }^{-1} \text { bios. } \\
\text { Solo degrad. }\end{array}$} & \multirow[t]{2}{*}{ Controle } & \multirow[t]{2}{*}{$\begin{array}{l}20 \text { t ha }^{-1} \text { bios. } \\
\text { Solo não-degr. }\end{array}$} & \multicolumn{2}{|c|}{$\begin{array}{l}20 \text { t ha }^{-1} \text { bios. } \\
\text { Solo degrad. }\end{array}$} \\
\hline & A & B & Bruto & Líquido & Bruto & Líquido & & & Bruto & Líquido \\
\hline Dia PPI & & & & & 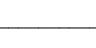 & $-\mathrm{kg} \mathrm{h}$ & & & & - \\
\hline 30 & 37 & 54 & 331 & 277 & 598 & 545 & 24 & 48 & -78 & 103 \\
\hline 60 & 26 & 32 & 89 & 57 & 74 & 43 & 24 & 47 & -83 & 108 \\
\hline 90 & 22 & 24 & 52 & 23 & 18 & -6 & 24 & 30 & -63 & 87 \\
\hline 120 & 21 & 21 & 40 & 20 & 8 & -12 & 24 & 19 & -46 & 71 \\
\hline 150 & 19 & 18 & 35 & 17 & 8 & -11 & 24 & 10 & -35 & 59 \\
\hline 180 & 19 & 17 & 32 & 15 & 10 & -7 & 24 & 5 & -26 & 51 \\
\hline 210 & 18 & 16 & 30 & 15 & 12 & -4 & 24 & 0 & -20 & 44 \\
\hline Total em 7 meses & 162 & 182 & 609 & 428 & 729 & 547 & 170 & 158 & -351 & 522 \\
\hline Total em 6 meses & 125 & 128 & 278 & 150 & 130 & 2 & 146 & 111 & -273 & 419 \\
\hline
\end{tabular}

\section{Quantidade de N mineralizado (\%)}

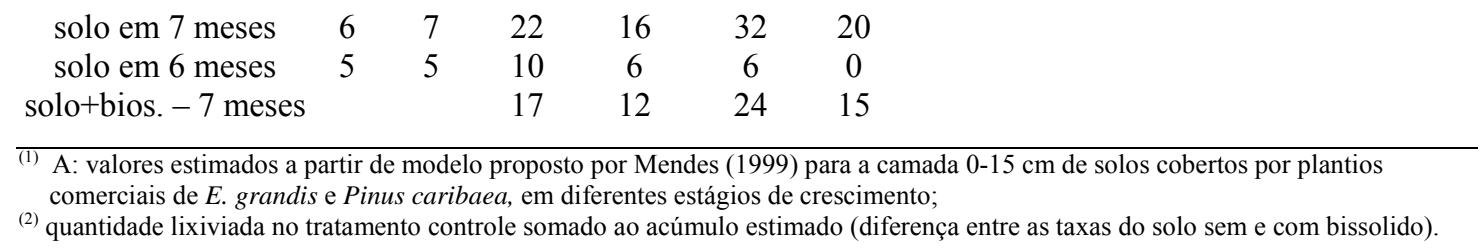


No solo degradado, houve acúmulo, em sete meses PPI, de $351 \mathrm{~kg} \mathrm{ha}^{-1} \mathrm{de}$ $\mathrm{N}$ mineral na camada $0-30 \mathrm{~cm}$, quantidade superior às perdas observadas no tratamento Controle (Tabela 12). A partir deste acúmulo e das perdas observadas no Controle, estimou-se lixiviação $581 \mathrm{~kg} \mathrm{ha}^{-1}$ de $\mathrm{N}$ mineral, nos primeiros sete meses PPI (equivalente a $70 \%$ do $\mathrm{N}$ aplicado via biossólido). Estes valores são similares aos observados por Robinson et al. (2002), que teve em seu experimento liberação de 53 a $69 \%$ do estoque de $\mathrm{N}$ orgânico considerado ativo nos primeiros meses pós-aplicação de biossólido. Tais resultados evidenciam a importância da serapilheira na manutenção de nutrientes no solo e os maiores riscos de aplicação do biossólido em áreas alteradas.

\subsubsection{Concentrações de $\mathrm{C}$ total, de $\mathrm{N}$ total e de matéria orgânica}

No solo não-degradado, houve alterações das concentrações de $\mathrm{C}$, de $\mathrm{N}$, da relação $\mathrm{C} / \mathrm{N}$ e de $\mathrm{MO}$, em função das doses crescentes de biossólido, aos sete e, ou aos doze meses PAB (Figuras 19 a 23). Aos sete meses, observou-se relação quadrática entre as doses de biossólido e a concentração de $\mathrm{C}$ total na camada $3-10 \mathrm{~cm}$, com diminuição até a dose $20 \mathrm{t} \mathrm{ha}^{-1}$, seguido de retorno a valores próximos ao tratamento Controle (Figura 19). A relação $\mathrm{C} / \mathrm{N}$ das camadas 0-3 e 10-20 cm também diminuiu com o aumento das doses de biossólido; efeito inverso foi observado na camada 20-30 cm, no entanto com pouca diferença entre valores (Figura 21). Aos doze meses, houve diminuição das concentrações da MO (de 20 a 38\%), nas camadas 0-3, 3-10 e 10-20 cm e de $\mathrm{N}$, na camada 20-30 cm do solo $(\mathrm{P}<0,05)$ (Figuras 20, 22 e 23).

No solo degradado, não houve efeito do biossólido sobre as concentrações de $\mathrm{C}$, de $\mathrm{N}$ total e de $\mathrm{MO}$, aos sete meses PAB. Estes resultados podem estar refletindo a grande variabilidade espacial dos dados nos tratamentos que receberam biossólido. Aos doze meses, contrariamente aos resultados observados nos tratamentos em solo não-degradado, as concentrações de MO aumentaram com a aplicação de doses crescentes de biossólido em todas as camadas amostradas (aumento de 14 a 97\%) (Figuras 22 e 23) $(\mathrm{P}<0,05)$. Estes aumentos também foram observados nas 
concentrações de C total, na camada 3-10 e 10-20 cm (Figura 19) e de $\mathrm{N}$ total, na camada 10-20 cm $(\mathrm{P}<0,05)$ (Figura 20).

Os resultados evidenciam diferença no comportamento da $\mathrm{MO}$ do solo em diferentes sistemas de manejo. $\mathrm{O}$ aumento na concentração de $\mathrm{C}$ orgânico em solo que recebeu biossólido, sob cultivo agrícola, foi observado por Logan et al. (1997) e Oliveira (2000). Por outro lado, em povoamentos de Eucalyptus grandis, num solo semelhante ao deste estudo (LVA textura média), conduzido no sistema de cultivo mínimo, a diminuição da concentração da MO do solo, após doze meses de aplicação de biossólido, foi observada por Vaz \& Gonçalves (2000) e Rocha (2002).

No solo não-degradado, as variações das concentrações de $\mathrm{C}$, de $\mathrm{N}$, da relação $\mathrm{C} / \mathrm{N}$ e da $\mathrm{MO}$ tem como explicação plausível a mineralização secundária desta última ou "efeito priming" (Kuzyakov et al., 2000), ocasionada pela transferência de N do biossólido ao solo. No solo não-degradado, de maior relação $\mathrm{C} / \mathrm{N}$ e constituído de frações grosseiras da $\mathrm{MO}$ em diferentes estágios de decomposição (mais reativas aos compostos oriundos do biossólido), o aporte de $\mathrm{N}$ induz o aumento da mineralização da MO.

No solo degradado, ficou evidenciado a transferência de compostos orgânicos solúveis, inferido pelo rápido aumento das concentrações da $\mathrm{MO}$ do solo (Figuras 22 e 23), do P e do S (Figuras 25 e 29). Ainda como explicação ao aumento da concentração da MO no solo degradado, com a remoção do topo do horizonte A, diminuíram-se as quantidades de MO lábil e manteve-se a fração associada às partículas de argila, com alta estabilidade, ciclagem lenta, associada a pequenos poros (De Neve \& Hofman, 2000) e, possivelmente, pouco reativa ao aporte de substâncias do biossólido, por isso, menos sujeitas ao "efeito priming". A menor porosidade do solo degradado também pode ter contribuído para o aumento das concentrações de MO. Em micronichos protegidos (poros menores que $6 \mathrm{~mm}$ ) (Killham et al., 1992), a mineralização da MO pode ser mais lenta, devido à menor vulnerabilidade ao ataque de predadores (Ladd et al., 1993). Em camadas subjacentes ao topo do horizonte A $(0-20 \mathrm{~cm})$, a maior quantidade de cargas positivas expostas nas partículas de argila podem ter favorecido o 
estabelecimento de ligações fracas com as moléculas orgânicas, propiciando a manutenção destas no sistema.
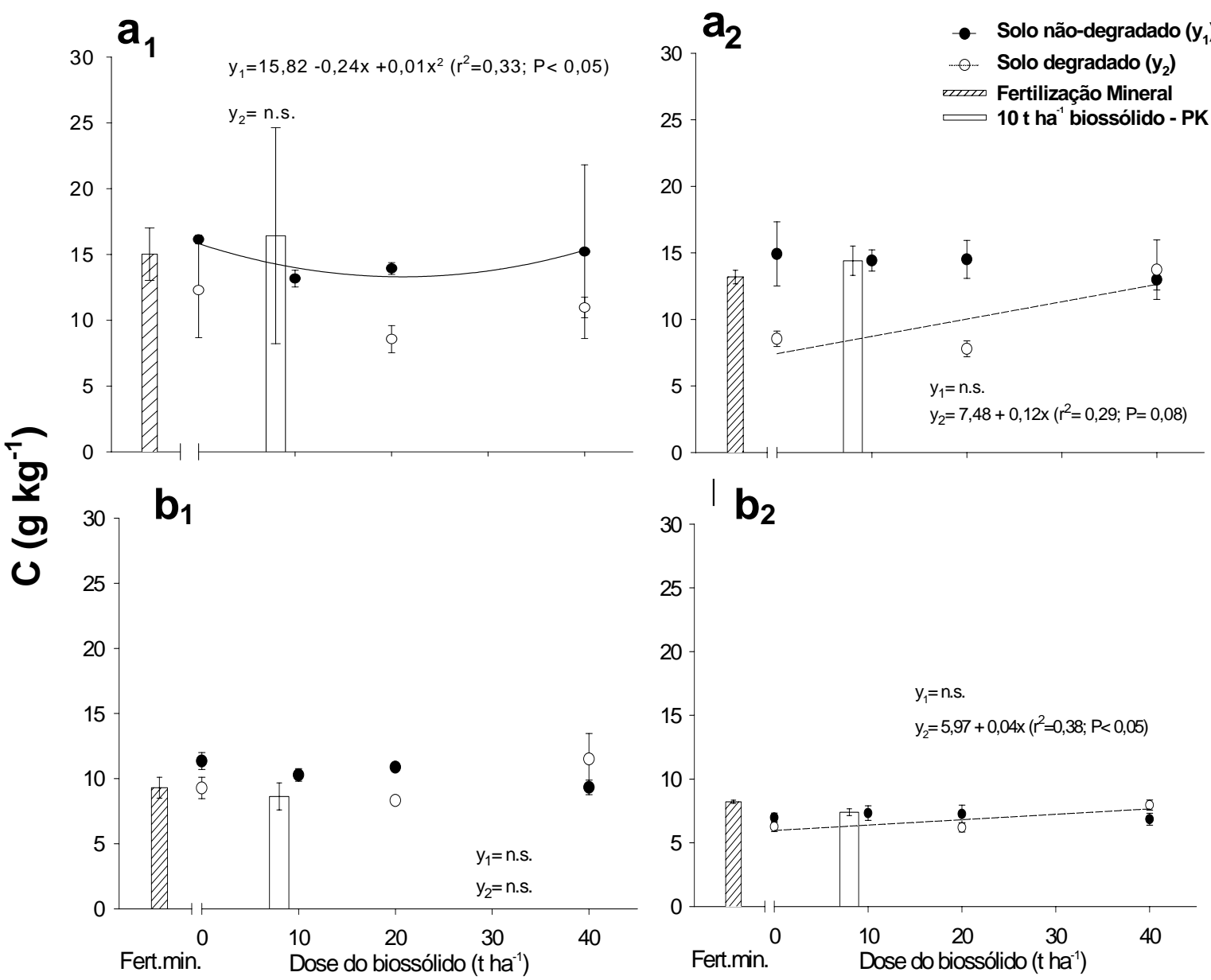

Figura 19- Concentração de C total (média \pm erro padrão) aos sete (1) e aos doze (2) meses pós-aplicação do biossólido, nas camadas 3-10 (a) e 10-20 cm (b) do solo não-degradado e degradado, nos diferentes tratamentos 

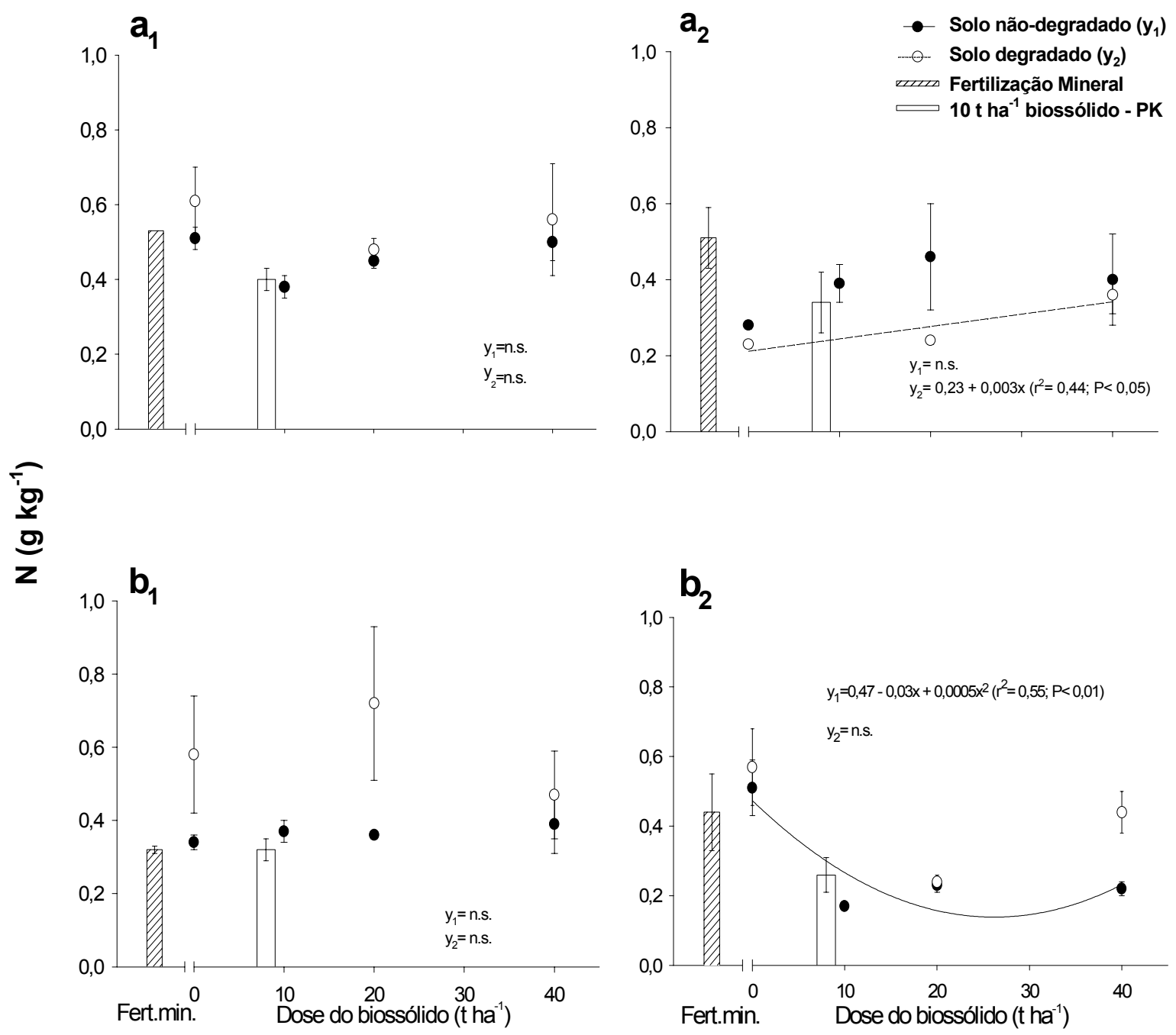

Figura 20- Concentração de $\mathrm{N}$ total (média \pm erro padrão) aos sete (1) e aos doze (2) meses pós-aplicação do biossólido, nas camadas 10-20 (a) e 20-30cm (b) do solo não-degradado e degradado, nos diferentes tratamentos 

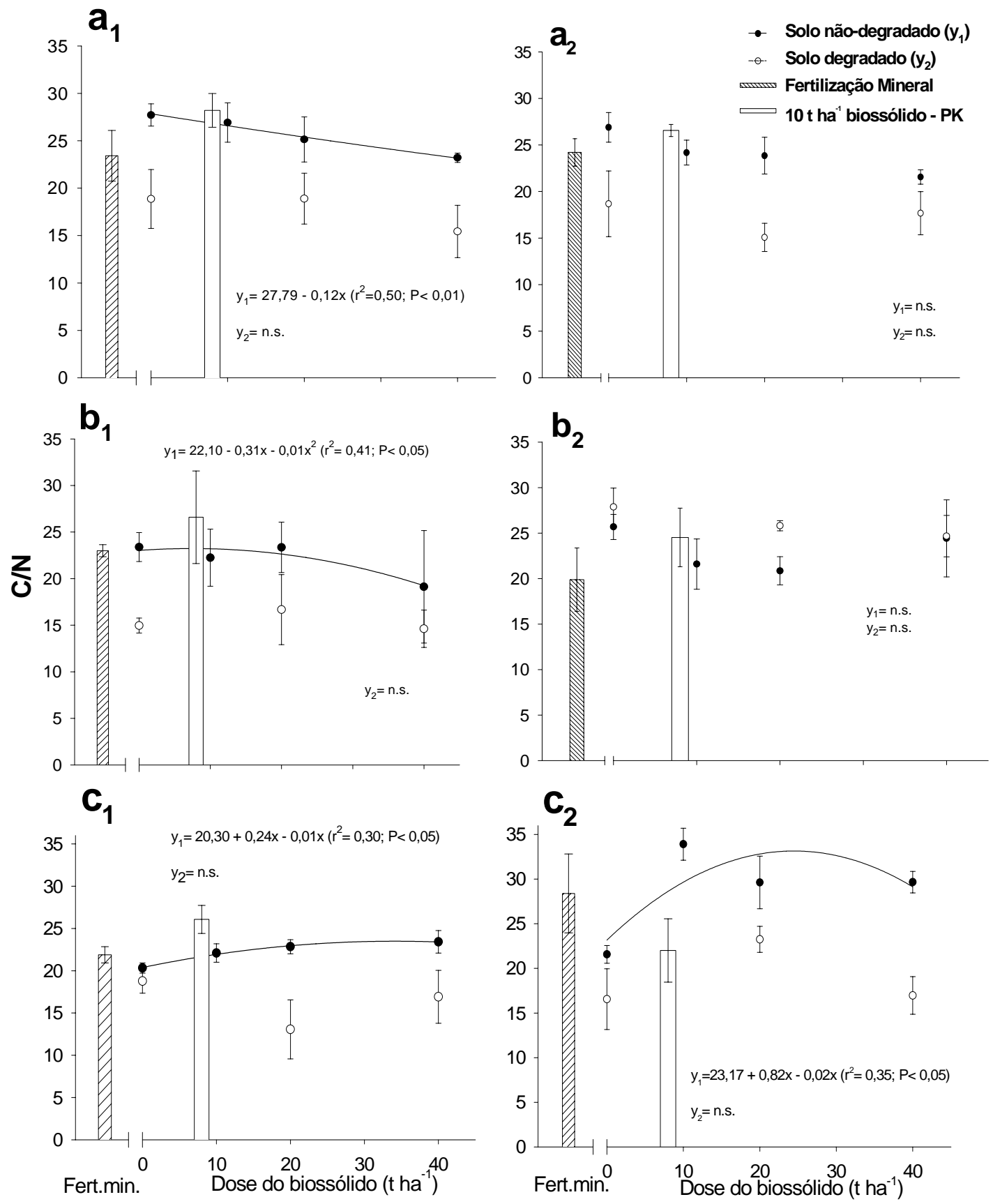

Figura 21- Relação C/N (média \pm erro padrão) aos sete (1) e aos doze meses (2) pós-aplicação do biossólido, nas camadas 0-3 (a), 10-20 (b) e 20-30 (c) cm do solo não-degradado e degradado, nos diferentes tratamentos 

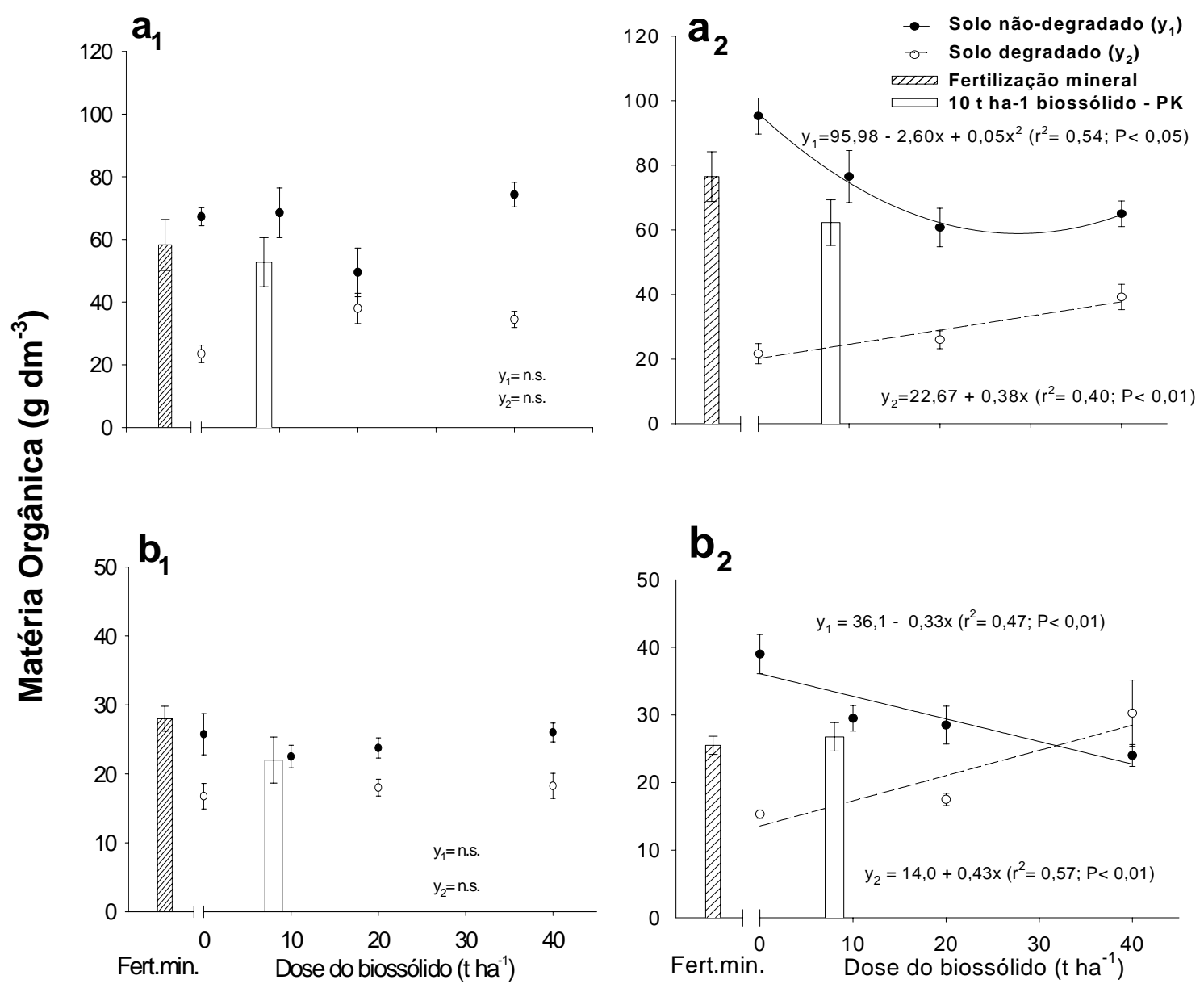

Figura 22- Concentração de matéria orgânica (média \pm erro padrão) aos sete (1) e aos doze (2) meses pósaplicação do biossólido, nas camadas 0-3 (a) e 3-10 cm (b) do solo não-degradado e degradado, nos diferentes tratamentos 

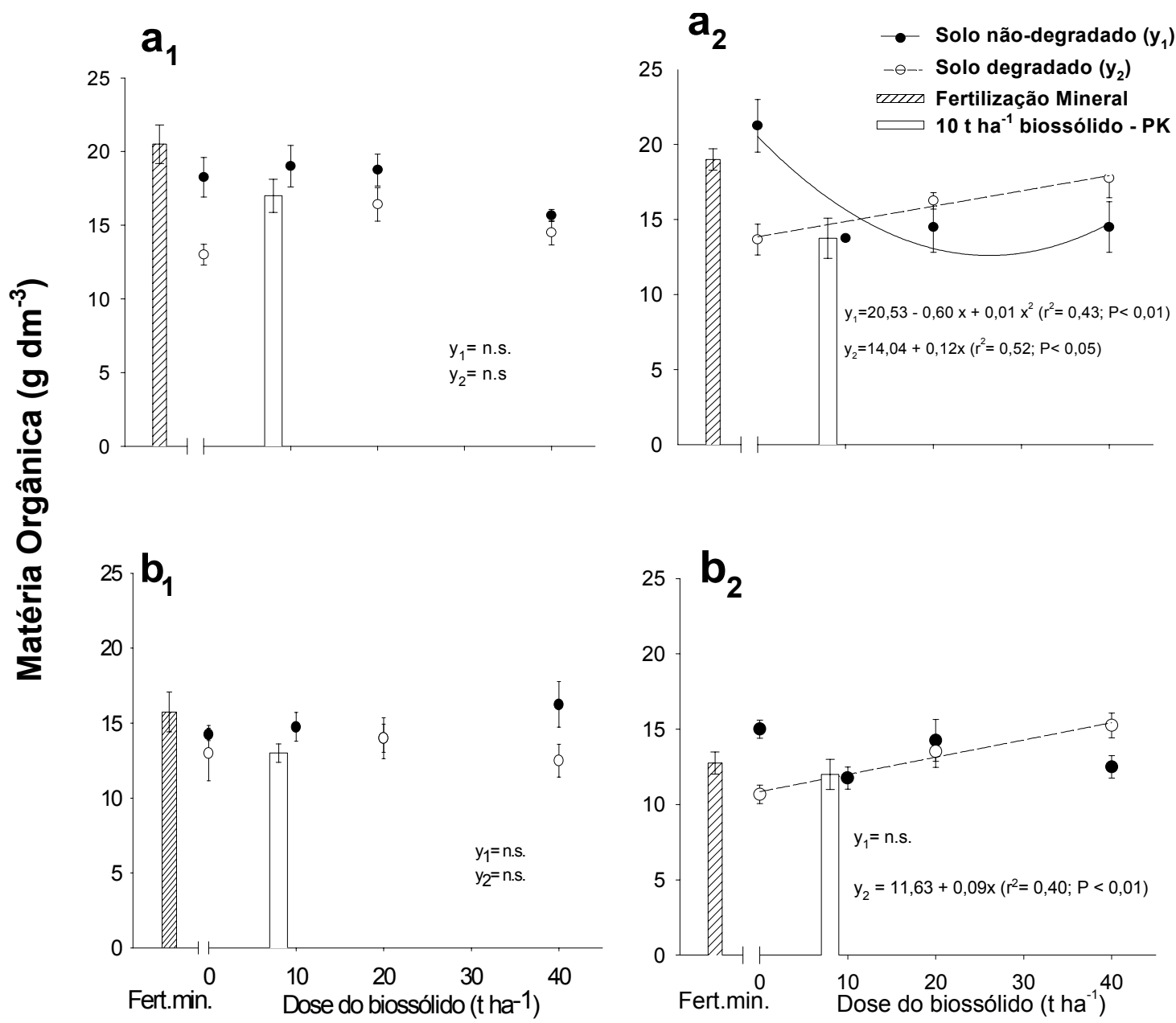

Figura 23- Concentração de matéria orgânica (média \pm erro padrão) aos sete (1) e aos doze (2) meses pósaplicação do biossólido, nas camadas 10-20 (a) e 20-30 cm (b) do solo não-degradado e degradado, nos diferentes tratamentos 


\subsection{4 pH}

O solo Controle (1) e sob a mistura serapilheira mais biossólido (20 t ha${ }^{1}$ ), de uma forma geral, tiveram $\mathrm{pH}$ semelhantes, nas diferentes camadas analisadas, dos 7 aos 89 dias $\mathrm{PAB}(\mathrm{P}<0,05)$ (Tabela 13). Os valores de $\mathrm{pH}$ do solo não-degradado foram menores do que o pH do solo degradado com aplicação de $20 \mathrm{t} \mathrm{ha}^{-1}$ de biossólido $(\mathrm{P}<0,05)$. Apesar da não relação com o tempo de aplicação, houve tendência a diminuição do pH do solo não-degradado com $20 \mathrm{t} \mathrm{ha}^{-1}$ de biossólido, entre 7 e 199 dias, nas camadas 3-10, 10-20 e 20-30 cm. Esta diminuição pode estar associada ao aumento da nitrificação, com conseqüente liberação de prótons e favorecimento da lixiviação de cátions (Harrison et al., 1996) (Figuras 26 a 28).

Aos sete meses PAB, houve aumento linear do $\mathrm{pH}$ da camada $0-3 \mathrm{~cm}$ em função das doses crescentes de biossólido, nos dois sistemas de cultivo (Figuras 24). Nesta camada, a influência do biossólido foi maior (Figuras 25 a 29) e, geralmente, as alterações da fertilidade pelos processos de mineralização mais intensos (Paul \& Conyers, 2001). O solo degradado apresentou aumento mais pronunciado do $\mathrm{pH}$ em função das doses crescentes de biossólido. No solo não-degradado, nesta camada, o pH aumentou de 3,5 $\pm 0,04$ (Controle) para 3,8 $\pm 0,05$ (40 $\mathrm{t} \mathrm{ha}^{-1}$ biossólido), e para o solo degradado, o aumento foi de 3,7 $\pm 0,09$ (Controle) para 4,3 $\pm 0,23$, com aplicação de $40 \mathrm{t}$ $\mathrm{ha}^{-1}$ biossólido. Esse efeito do biossólido também foi significativo na camada 10-20 cm do solo degradado, no entanto, com diminuição de pH muito tênue com a aplicação de doses crescentes de biossólido. $\mathrm{O}$ aumento do $\mathrm{pH}$ do solo aos sete meses PAB pode ser atribuído aos seguintes fatores (Yan et al., 1996): i) transferência de cátions do biossólido para o solo, que substituem $\mathrm{H}$ e $\mathrm{Al}$ dos sítios de troca e aumentam a saturação por bases do solo (Figuras 28 a 30); ii) liberação de $\mathrm{NH}_{3}$ da decomposição de $\mathrm{N}$ orgânico (desaminação) e formação de $\mathrm{NH}_{4}{ }^{+}$(Figuras 12 a 15); iii) troca de ligantes entre hidróxidos de Fe e Al e ânions orgânicos como malato, citrato e tartrato; e vi) adição de ânions orgânicos e de aminoácidos, que podem aumentar o $\mathrm{pH}$ por processos 
de descarboxilação. Este processo é estimulado principalmente pela atividade de microorganismos, que consome protons ${ }^{1}$ (Yan et al., 1992).

Aos doze meses $\mathrm{PAB}$, não houve relação entre as doses de biossólido e o pH das camadas 0-3 e 3-10 cm, nos dois sistemas de cultivo, possivelmente pela diminuição da umidade e temperatura do solo, inibindo os processos químicos e microbiológicos (Figura 24). Foi possível estabelecer uma equação linear entre o pH da camada 20-30 cm do solo degradado, no entanto com diferenças muito pequenas entre valores.

Tabela 13. Variação do pH nos primeiros sete meses pós-aplicação do biossólido (PAB), no solo não-degradado sem e com $20 \mathrm{t} \mathrm{ha}^{-1}$ de biossólido, e no solo degradado com $20 \mathrm{tha}^{-1}$ de biossólido ${ }^{(1)}$

\begin{tabular}{|c|c|c|c|}
\hline \multirow[t]{2}{*}{$\overline{\text { Dias PAB }}$} & \multirow{2}{*}{$\begin{array}{c}\text { Controle } \\
\text { (Tratamento 1) }\end{array}$} & \multicolumn{2}{|c|}{20 t ha $^{-1}$ biossólido } \\
\hline & & Cultivo Mínimo & Solo Degradado \\
\hline & & $0-3 \mathrm{~cm}$ & \\
\hline 7 & $3,35 \mathrm{a}$ & $3,38 \mathrm{a}$ & $4,64 b$ \\
\hline 26 & $3,54 \mathrm{a}$ & $3,69 \mathrm{a}$ & $4,32 \mathrm{~b}$ \\
\hline 89 & $3,43 \mathrm{a}$ & $3,72 \mathrm{a}$ & $4,95 \mathrm{~b}$ \\
\hline \multirow[t]{2}{*}{199} & $3,58 \mathrm{a}$ & $3,64 \mathrm{a}$ & $3,88 \mathrm{a}$ \\
\hline & & $3-10 \mathrm{~cm}$ & \\
\hline 7 & $3,57 \mathrm{a}$ & $3,67 \mathrm{a}$ & $3,90 \mathrm{a}$ \\
\hline 26 & $3,61 \mathrm{a}$ & $3,67 \mathrm{ab}$ & $3,98 \mathrm{~b}$ \\
\hline 89 & $3,65 \mathrm{ab}$ & $3,54 \mathrm{a}$ & $3,93 \mathrm{~b}$ \\
\hline \multirow[t]{2}{*}{199} & $3,55 \mathrm{ab}$ & $3,42 \mathrm{a}$ & $3,80 \mathrm{~b}$ \\
\hline & & $10-20 \mathrm{~cm}$ & \\
\hline 7 & $3,97 \mathrm{a}$ & $4,03 \mathrm{a}$ & $4,15 \mathrm{a}$ \\
\hline 26 & $4,07 \mathrm{a}$ & $4,05 \mathrm{a}$ & $4,14 \mathrm{a}$ \\
\hline 89 & $4,01 \mathrm{a}$ & $3,85 \mathrm{a}$ & $3,93 \mathrm{a}$ \\
\hline \multirow[t]{2}{*}{199} & $3,96 \mathrm{ab}$ & $3,71 \mathrm{a}$ & $4,05 \mathrm{~b}$ \\
\hline & & $20-30 \mathrm{~cm}$ & \\
\hline 7 & $4,04 \mathrm{a}$ & $4,09 \mathrm{a}$ & $4,17 \mathrm{a}$ \\
\hline 26 & $4,17 \mathrm{a}$ & $4,13 \mathrm{a}$ & $4,21 \mathrm{a}$ \\
\hline 89 & $4,06 \mathrm{a}$ & $3,95 \mathrm{a}$ & $3,98 \mathrm{a}$ \\
\hline 199 & $4,02 \mathrm{a}$ & $3,91 \mathrm{a}$ & $4,02 \mathrm{a}$ \\
\hline
\end{tabular}

1 Reação: $\mathrm{R}-\mathrm{CO}-\mathrm{COO}^{-}+\mathrm{H}^{+} \rightarrow \mathrm{R}-\mathrm{COH}+\mathrm{CO}_{2}$ 

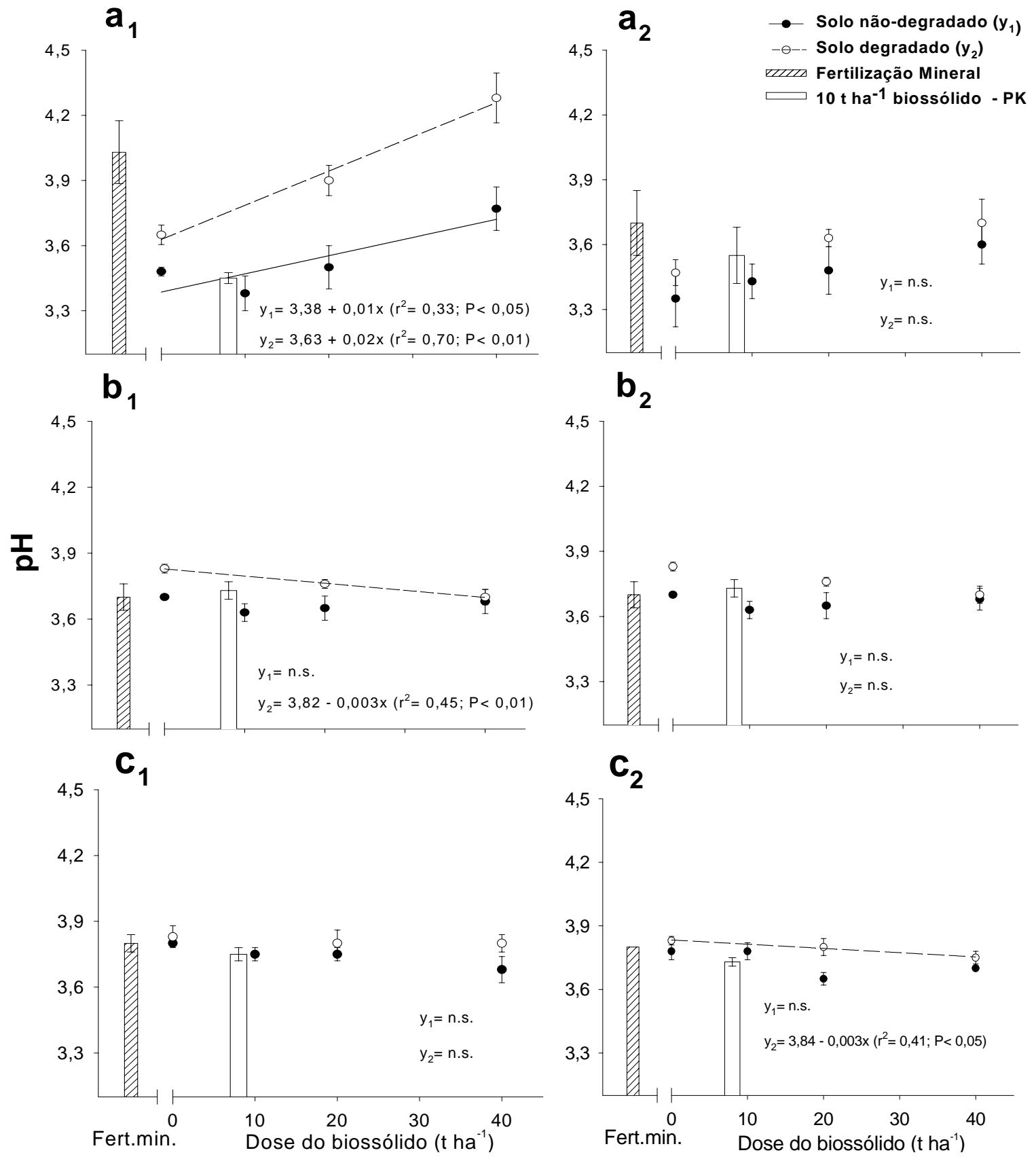

Figura 24- pH (média + erro padrão) aos sete (1) e aos doze (2) meses pós-aplicação do biossólido, nas camadas 0-3 (a), 10-20 (b) e 20-30 cm (c) do solo não-degradado e degradado, nos diferentes tratamentos 


\subsubsection{Fósforo}

Houve aumento das concentrações de P-resina no solo com a aplicação de doses crescentes de biossólido aos sete e aos doze meses PAB, nos dois sistemas de cultivo, evidenciados principalmente na camada 0-3 cm (Figura 25). Nesta camada, as concentrações de $\mathrm{P}$, nos tratamentos que receberam biossólido, foram 6 a 35 vezes maior no solo não-degradado e 6 a 43 vezes maior no solo degradado, em relação aos tratamentos Controles ( 1 e 7 , respectivamente), nos dois períodos de amostragem. A similaridade das concentrações de P-resina do solo, entre os tratamentos 3 e $6\left(10 \mathrm{t} \mathrm{ha}^{-1}\right.$ de biossólido, com e sem suplementação de P no sulco de plantio, respectivamente) e as maiores concentrações de $\mathrm{P}$ em todos os tratamentos que receberam biossólido, evidenciam que o aumento de $\mathrm{P}$ nas camadas superficiais do solo não teve relação com a fertilização realizada no sulco de plantio.

Aos sete meses PAB, o aumento de P-resina na camada 0-3 cm do solo não-degradado foi linear $(\mathrm{P}<0,01)$ (Figura 25), com concentrações variando de 2,8 $\pm 0,2$ $\mathrm{mg} \mathrm{dm}{ }^{-3}$, Controle, a $82 \pm 18,1 \mathrm{mg} \mathrm{dm}^{-3}, 40 \mathrm{t} \mathrm{ha}^{-1}$ de biossólido. Neste tipo de cultivo, os tratamentos que receberam biossólido apresentaram concentrações de P-resina que podem ser classificadas como altas a muito altas para eucalipto (Gonçalves et al., 1996). Na camada 3-10 cm, pôde-se estabelecer uma equação de regressão $(\mathrm{P}<0,05)$; no entanto os valores observados para $P$ foram baixos, variando de $3,0 \pm 0,3$ a 4,5 $\pm 0,6 \mathrm{mg} \mathrm{dm}^{-3}$.

No mesmo período, na camada $0-3 \mathrm{~cm}$ do solo degradado, as concentrações de P-resina $\left(3,3 \pm 0,5\right.$, Controle, a 107,7 $\pm 10,4 \mathrm{mg} \mathrm{dm}^{-3}$, com aplicação de $40 \mathrm{t} \mathrm{ha}^{-1}$ de biossólido) foram maiores às observadas na mesma camada, no solo nãodegradado (Figura 25). Nas demais camadas, não houve relação entre as doses de biossólido e as concentrações de P-resina. No entanto, na camada 20-30 cm do solo com aplicação de $20 \mathrm{t} \mathrm{ha}^{-1}$ de biossólido, a concentração média de $\mathrm{P}$ foi maior do que os demais tratamentos $\left(16,2 \pm 2,7 \mathrm{mg} \mathrm{dm}^{-3}\right)$. Esta variação pode estar relacionada com a variabilidade espacial da distribuição do biossólido. 

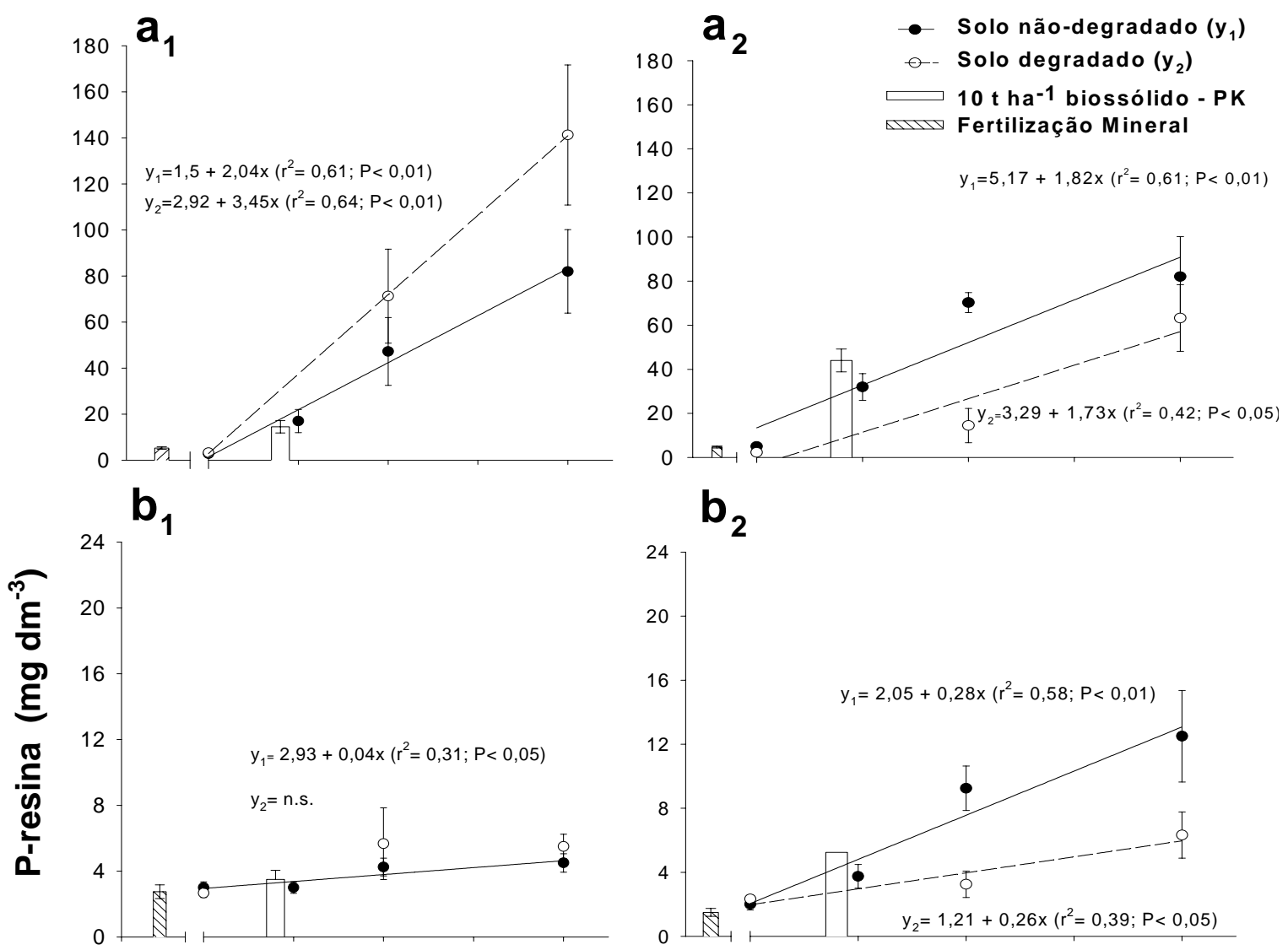

$b_{2}$
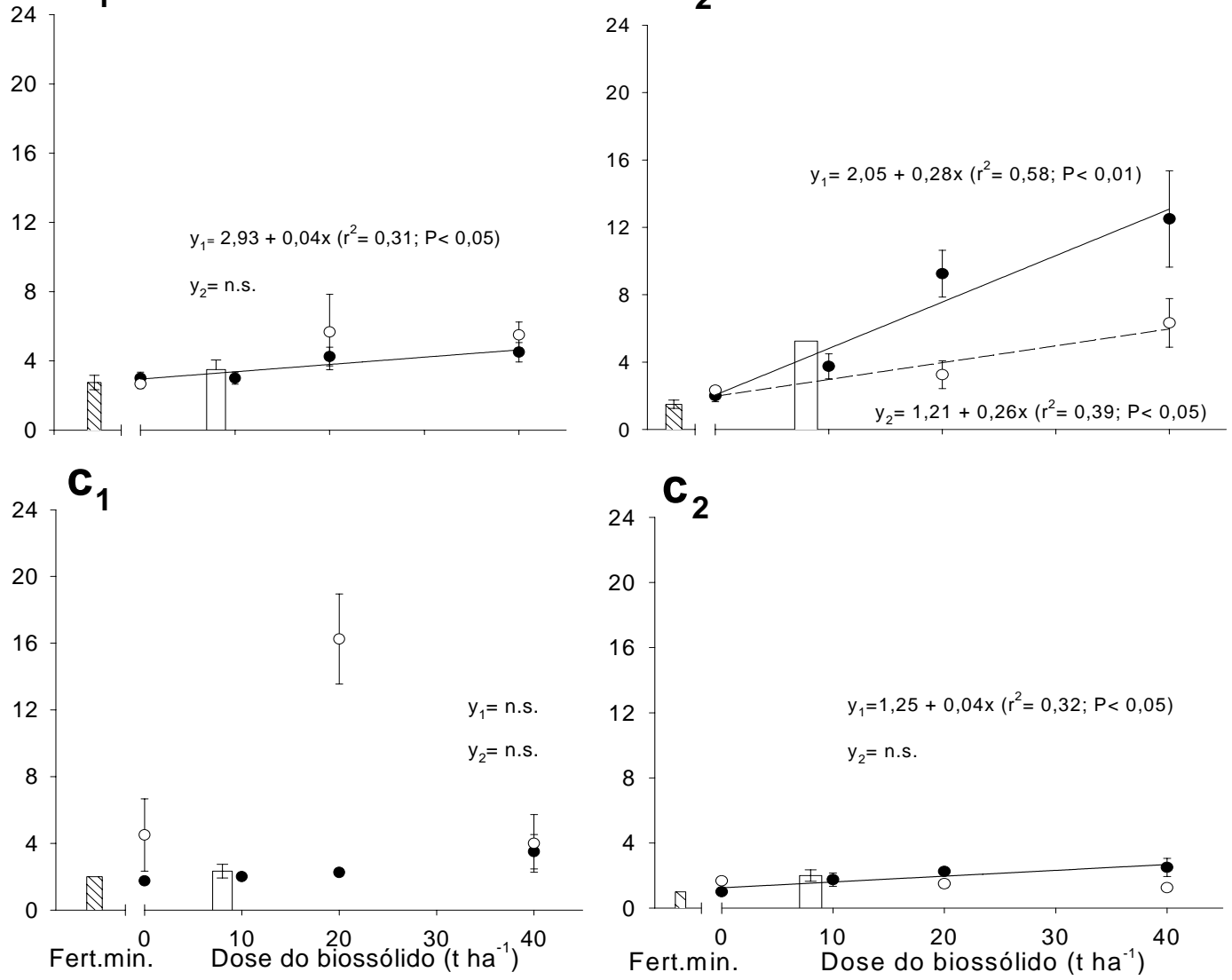

Figura 25- Concentração de P-resina (média + erro padrão) aos sete (1) e aos doze (2) meses pós-aplicação do biossólido, nas camadas 0-3 (a), 3-10 (b) e 20-30 cm (c) do solo não-degrado e degradado, nos diferentes tratamentos 
A transferência de P-resina no solo, em profundidade, foi mais evidente aos doze meses pós-aplicação do biossólido, tanto no solo não-degradado como no degradado (Figura 25). No solo não-degradado, os resultados correspondem à maior liberação de P da serapillheira mais biossólido entre sete e doze meses PAB (Tabela 11). Neste, houve aumento linear das concentrações de P com a aplicação de doses crescentes de biossólido, nas camadas 0-3, 3-10 e 20-30 cm, com concentrações variando de $5,0(0,6)$ a $82,0(18,12), 2,0(0,3)$ a $12,5(2,86)$ e 1,0 a $2,5(0,6) \mathrm{mg} \mathrm{dm}^{-3}$ (Controle a $40 \mathrm{t} \mathrm{ha}^{-1}$, respectivamente). Importante observar a manutenção da magnitude de valores, entre sete e doze meses, na camada 0-3 cm, e aumento das concentrações nas camadas 3-10 cm do solo não-degradado. Aos doze meses, no solo degradado, o aumento também foi linear, nas camadas 0-3 e 3-10 cm, com concentrações variando de $2,3(0,5)$ a $63,2(15,1)$ e $2,3(0,2)$ a $6,3(1,4) \mathrm{mg} \mathrm{dm}^{-3}$ (Controle e $40 \mathrm{t} \mathrm{ha}^{-1}$ de biossólido, respectivamente) (Figura 25). Contrariamente ao solo não-degradado, houve diminuição das concentrações de $\mathrm{P}$, entre sete e doze meses, na camada 0-3 cm.

$\mathrm{O}$ rápido aumento do $\mathrm{P}$, nos primeiros $10 \mathrm{~cm}$ do solo sob os dois sistemas de cultivo, pode ser atribuído: i) à rápida solubilização e mineralização do $\mathrm{P}$ oriundo do biossólido (baixa relação C/P) (Berton et al., 1989); ii) à forma inorgânica de grande parte do $\mathrm{P}$ contido em biossólido digerido anaerobicamente (Sommers et al., 1976); iii) à neutralização de sítios de fixação de P, por ácidos orgânicos (Rydin \& Otabbong, 1997; Gonçalves \& Barros, 1999; Abreu Junior et al., 2002) e ânions inorgânicos (Tisdale et al., 1985) e, em menor importância, (iii) ao aumento do pH do solo (aos sete meses, na camada 0-3 cm, pH de 3,5 a 4,8 e 3,6 a 4,4 no solo não-degradado e degradado, respectivamente) (Figura 25), que diminui os sítios de adsorção de $\mathrm{P}$ dos colóides do solo (Hue \& Licudine, 1999). Em relação à solubilização dos compostos fosfatados contidos no biossólido, a diminuição do pH deste, de 7 a 4,7 (mistura serapilheira mais biossólido) e 5,2 (biossólido puro sobre solo degradado) (Tabela 9), pode ter favorecido a solubilização do $\mathrm{AlPO}_{4}$, com formação de $\mathrm{Al}(\mathrm{OH})_{3}$ e conseqüente liberação de $\mathrm{P}$ ao solo (Rydin \& Otabbong, 1997). Vaz \& Gonçalves (2002) e Rocha (2002), ao aplicarem biossólido condicionado com cal em um Latossolo Vermelho-Amarelo textura média, encontraram menores concentrações de P-resina. A menor concentração de $\mathrm{Ca}$ no 
biossólido condicionado com polieletrólito (em relação ao condicionado com cal) e a não reação deste cátion com o $\mathrm{P}$ (insolubilização) explicam em parte a maior extração de $\mathrm{P}$ encontrados neste trabalho.

No solo não-degradado, o aumento da concentração de $\mathrm{P}$ aos doze meses PAB deve estar relacionado à diminuição do impedimento físico causado pela serapilheira e a imobilização microbiológica de $\mathrm{P}$ neste resíduo; com a intensificação dos processos de mineralização da mistura seraplheira mais biossólido, ocorre a gradual manutenção das concentrações de P no solo (James et al., 1992). Além disso, a maior concentração de $\mathrm{MO}$ do solo $\left(30 \mathrm{mg} \mathrm{dm}^{-3}\right.$ no solo não-degradado e $19 \mathrm{mg} \mathrm{dm}^{-3}$ no solo degradado, camada 0-10 cm), a menor saturação por Al (Moreira et al., 2001) (69 e 84\% no solo não-degradado e 84 e $82 \%$ no solo degradado, camada 0-3 e 3-10 cm, respectivamente) (Tabela 7) e a possível saturação dos sítios de adsorção de $\mathrm{P}$ dos colóides contribuem para a manutenção ou para o aumento das concentrações de P. Outros fatores físicos, como a maior retenção de umidade e a maior porosidade no solo não-degradado também devem ter contribuído para a maior concentração de $\mathrm{P}$ aos doze meses PAB, por propiciar melhores condições de mineralização do P orgânico do solo e oriundo do biossólido.

A quantidade de P aplicada via biossólido (250, 500 e $1000 \mathrm{~kg} \mathrm{ha}^{-1}$ de P em 10, 20 e $40 \mathrm{t} \mathrm{ha}^{-1}$ de biossólido) foi muito maior do que a quantidade necessária para uma adequada nutrição do eucalipto em um ciclo da cultura (fertilização de 13 a $26 \mathrm{~kg}$ $\mathrm{ha}^{-1}$ de $\mathrm{P}^{2}$ ). Entretanto, o tipo de solo estudado geralmente apresenta grande capacidade de adsorção de $\mathrm{P}$ (aproximadamente 500 e $650 \mathrm{~kg} \mathrm{ha}^{-1}$ na camada $0-10 \mathrm{~cm}$ do solo nãodegradado e degradado, respectivamente) (Moreira et al., 2001); esta capacidade pode ser aumentada com a adição, junto ao biossólido, de Fe e Al extraíveis com oxalato (Fe e Al livre) (Maguire et al., 2000). Um controle complementar das quantidades de P no solo pode ser realizado pela intensa absorção do $\mathrm{P}_{-} \mathrm{PO}_{4}^{-2}$ pelo eucalipto e pelo subbosque, evitando, desta forma, excessos ao ambiente (Medalie et al., 1994). 


\subsubsection{Potássio}

Houve alterações significativas das concentrações de $\mathrm{K}$ apenas na camada 3-10 cm do solo não-degradado, aos sete meses PAB (Figura 26; Tabela 14). As concentrações de $\mathrm{K}$ diminuíram em função das doses crescentes de biossólido $(\mathrm{P}<0,05)$ : variação de $0,53(0,22) \mathrm{mmol}_{\mathrm{c}} \mathrm{dm}^{-3}$ no Controle para $0,18(0,06) \mathrm{mmol}_{\mathrm{c}} \mathrm{dm}^{-3}$ no tratamento que recebeu $40 \mathrm{t} \mathrm{ha}^{-1}$ de biossólido (Figura 26). Nesta época, o tratamento que recebeu $10 \mathrm{t} \mathrm{ha}^{-1}$ de biossólido sem suplementação de $\mathrm{P}$ e $\mathrm{K}$ apresentou a menor concentração de $\mathrm{K}$, na camada $0-3$ e 3-10 cm $(0,25 \pm 0,10$ e 0,15 $\pm 0,09$, respectivamente). Isso indica a pouca contribuição do biossólido para o aporte de $\mathrm{K}$ no solo. As concentrações de $\mathrm{K}$ estão dentro da classe considerada baixa para recomendação de adubação potássica para o cultivo de eucalipto $\left(<0,7 \mathrm{mmol}_{\mathrm{c}} \mathrm{dm}^{-3}\right)$ (Gonçalves et al., 1996). Silva et al. (2001), ao aplicar biossólido no sulco de plantio de cana-de-açúcar (30 cm de profundidade) em um Argissolo Vermelho-Amarelo distrófico, também constataram pequena diminuição da disponibilidade de $\mathrm{K}$ trocável no solo, atribuída ao aumento da absorção do nutriente pela cultura.

Após doze meses PAB, houve sensível aumento das concentrações de $\mathrm{K}$ nas diferentes camadas, em comparação ao período anterior de amostragem (Tabela 15). Este aumento está relacionado à liberação de $\mathrm{K}$ da serapilheira e do biossólido e a suplementação de $\mathrm{K}$ via fertilização de cobertura. No entanto, as concentrações de K nas diferentes camadas do solo, em todos os tratamentos sob solo não-degradado, ficaram dentro da classe considerada baixa para interpretação de recomendação de adubação potássica, segundo Gonçalves et al. (1996). As concentrações de K no tratamento que recebeu fertilização mineral, nas camadas 3-10 e 10-20 cm do solo, foram maiores do que as concentrações dos tratamentos que receberam biossólido, independente da suplementação de K. Este resultado indica lixiviação de K para as camadas subjacentes

\footnotetext{
${ }^{2}$ Quantidade de fertilizante recomendada para florestamentos de alto investimento, ou seja, alto nível tecnológico, admitindo-se taxa de 50\% de eficiência de aproveitamento da fonte de P (Gonçalves et al., 2002).
} 
nos tratamentos que receberam biossólido, o qual teria migrado como pares iônicos com o $\mathrm{N}-\mathrm{NO}_{3}{ }^{-}$e o S-SO ${ }_{4}^{2-}$ (Harrison et al., 1996).

No solo degradado, não houve diferenças significativas das concentrações de K na camada 0-30 cm, nos dois períodos amostrados. As concentrações de K ficaram dentro da classe considerada baixa para interpretação de recomendação de adubação potássica segundo Gonçalves et al. (1996). Este resultado reflete a exposição da camada subjacente do solo (mais pobre em K) e das altas taxas de absorção de K pelas plantas em fase de rápido crescimento.
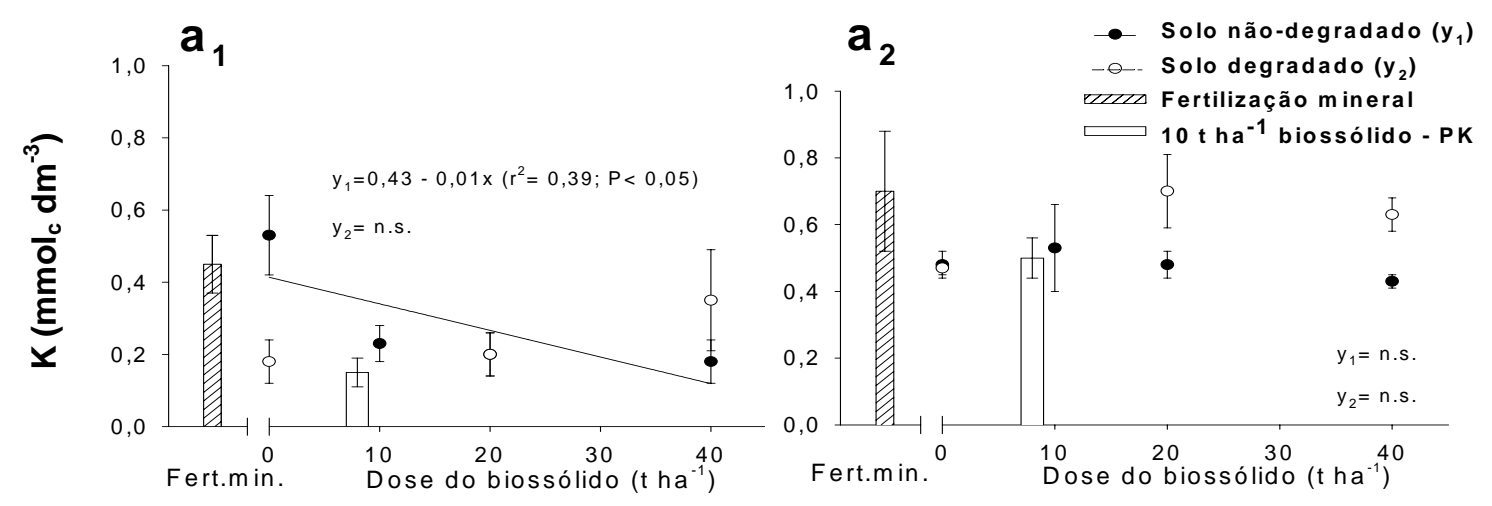

Figura 26- Concentração de K trocável (média \pm erro padrão) aos sete (1) e aos doze (2) meses pósaplicação do biossólido, na camada 3-10 cm (a) do solo não-degradado e degradado, nos diferentes tratamentos 
Tabela 14. Concentração de K trocável no solo em diferentes tratamentos (média \pm erro padrão), aos sete e aos doze meses pós-aplicação do biossólido (PAB)

\begin{tabular}{|c|c|c|c|c|c|c|}
\hline \multirow[b]{2}{*}{ Prof. } & \multicolumn{6}{|c|}{ Tratamentos } \\
\hline & Controle & $\begin{array}{c}10 \mathrm{t} \mathrm{ha}^{-1} \\
\text { bios.+PK }\end{array}$ & $\begin{array}{l}20 \mathrm{t} \mathrm{ha}^{-1} \\
\text { bios.+PK }\end{array}$ & $\begin{array}{c}40 \mathrm{t} \mathrm{ha}^{-1} \\
\text { bioss. }+\mathrm{PK}\end{array}$ & $\begin{array}{l}10 \mathrm{t} \mathrm{ha}^{-1} \\
\text { bios. - PK }\end{array}$ & $\begin{array}{c}\text { Fert. } \\
\text { Mineral }\end{array}$ \\
\hline
\end{tabular}

\section{Solo não-degradado}

Sete meses PAB

$\begin{array}{cllllll}0-3 & 0,68 \pm 0,13 & 0,65 \pm 0,36 & 0,65 \pm 0,15 & 0,90 \pm 0,19 & 0,25 \pm 0,21 & 0,58 \pm 0,22 \\ 3-10 & 0,53 \pm 0,22 & 0,23 \pm 0,11 & 0,20 \pm 0,12 & 0,18 \pm 0,13 & 0,15 \pm 0,09 & 0,45 \pm 0,17 \\ 10-20 & 0,30 \pm 0,21 & 0,20 \pm 0,12 & 0,23 \pm 0,22 & 0,10 \pm 0,00 & 0,15 \pm 0,09 & 0,28 \pm 0,13 \\ 20-30 & 0,37 \pm 0,18 & 0,23 \pm 0,16 & 0,25 \pm 0,11 & 0,18 \pm 0,13 & 0,17 \pm 0,08 & 0,10 \pm 0,00\end{array}$

\section{Doze meses PAB}

$\begin{array}{ccccccc}0-3 & 1,15 \pm 0,38 & 1,13 \pm 0,17 & 0,83 \pm 0,04 & 0,85 \pm 0,07 & 0,78 \pm 0,07 & 1,05 \pm 0,07 \\ 3-10 & 0,48 \pm 0,04 & 0,53 \pm 0,13 & 0,48 \pm 0,04 & 0,43 \pm 0,02 & 0,50 \pm 0,06 & 0,70 \pm 0,18 \\ 10-20 & 0,45 \pm 0,07 & 0,33 \pm 0,10 & 0,45 \pm 0,04 & 0,35 \pm 0,06 & 0,38 \pm 0,09 & 0,98 \pm 0,39 \\ 20-30 & 0,45 \pm 0,08 & 0,50 \pm 0,18 & 0,38 \pm 0,02 & 0,50 \pm 0,12 & 0,48 \pm 0,04 & 0,40 \pm 0,00\end{array}$

\section{Solo degradado}

\section{Sete meses PAB}

$\begin{array}{ccc}0-3 & 0,30 & \pm 0,10 \\ 3-10 & 0,18 & \pm 0,13 \\ 10-20 & 0,18 & \pm 0,08 \\ 20-30 & 0,20 & \pm 0,12\end{array}$

$$
\begin{array}{ll}
0,60 \pm 0,35 & 0,28 \pm 0,11 \\
0,20 \pm 0,12 & 0,35 \pm 0,29 \\
0,12 \pm 0,03 & 0,33 \pm 0,15 \\
0,30 \pm 0,19 & 0,20 \pm 0,10
\end{array}
$$

\section{Doze meses PAB}

$\begin{array}{ccccc}0-3 & 0,63 & \pm 0,13 & 0,98 \pm 0,22 & 0,73 \pm 0,10 \\ 3-10 & 0,47 & \pm 0,02 & 0,70 \pm 0,11 & 0,63 \pm 0,05 \\ 10-20 & 0,50 & \pm 0,04 & 0,63 \pm 0,14 & 0,53 \pm 0,04 \\ 20-30 & 0,43 & \pm 0,02 & 0,43 \pm 0,04 & 0,40 \pm 0,07\end{array}$




\subsubsection{Cálcio}

A aplicação do biossólido alterou as concentrações de $\mathrm{Ca}$, nos dois sistemas de cultivo, até $10 \mathrm{~cm}$ do solo $(\mathrm{P}<0,05)$ (Figura 27). No solo não-degradado, houve relação quadrática entre as doses de biossólido e as concentrações de Ca trocável, com diminuição destas nas doses 10 e $20 \mathrm{t} \mathrm{ha}^{-1}$, seguido por aumento $(0-3 \mathrm{~cm})$ ou estabilização $(3-10 \mathrm{~cm}) \quad(\mathrm{P}<0,05)$. As camadas 0-3 e $3-10 \quad \mathrm{~cm}$ apresentaram concentrações de Ca variando de 16,3 $\pm 2,7\left(20 \mathrm{t} \mathrm{ha}^{-1}\right)$ a 29,0 $\pm 2,2 \mathrm{mmol}_{\mathrm{c}} \mathrm{dm}^{-3}\left(40 \mathrm{tha}^{-1}\right)$, valores considerados altos para a camada 0-20 cm, segundo Raij et al. (1996) (>7 mmol $_{\mathrm{c}}$ $\mathrm{dm}^{-3}$ ). Na camada 3-10 cm, apenas o tratamento que recebeu calagem (fertilização mineral) apresentou concentrações médias $\left(4-7 \mathrm{mmol}_{\mathrm{c}} \mathrm{dm}^{-3}\right)$ e, nos demais tratamentos, as concentrações ficaram dentro da classe considerada baixa, de acordo com Raij et al. (1996) (0-3 $\mathrm{mmol}_{\mathrm{c}} \mathrm{dm}^{-3}$, camada 0-20 cm ).

Aos doze meses $\mathrm{PAB}$, no solo não-degradado, não houve relação significativa entre as doses de biossólido e as concentrações de Ca, (Figura 27). Isto ocorreu, possivelmente, em virtude da ausência de chuvas (agosto/2002). Contudo, numericamente, manteve-se a tendência à diminuição das concentrações de $\mathrm{Ca}$ nos tratamentos com 10 e $20 \mathrm{t} \mathrm{ha}^{-1}$ de biossólido, seguido de aumento. Neste período, houve aumento das concentrações de $\mathrm{Ca}$, em todos os tratamentos, com maior média para o tratamento sob fertilização mineral $\left(38,25 \mathrm{mmol}_{\mathrm{c}} \mathrm{dm}^{-3}\right.$, camada $0-3 \mathrm{~cm}$ do solo).

No solo degradado, na camada 0-3 cm aos sete meses e nas camadas 0-3 e 3-10 cm aos doze meses PAB, houve aumento linear das concentrações de Ca com a aplicação de doses crescentes de biossólido, (Figura 27). A concentração de $\mathrm{Ca}$ na camada 0-3 cm diminuiu, dos sete aos doze meses PAB, em todos os tratamentos. Possivelmente esta diminuição foi devido à transferência do $\mathrm{Ca}$ para camadas subsuperficiais e, ou, secundariamente, devido a alta absorção deste nutriente pelas plantas, efeito menos provável pois as concentrações foliares de Ca foram baixas (Figura 31). As concentrações variaram de 1,0-1,5 $\mathrm{mmol}_{\mathrm{c}} \mathrm{dm}^{-3}$ (Controle, 0-30 cm) a 31,5 $\mathrm{mmol}_{\mathrm{c}} \mathrm{dm}^{-3}\left(40 \mathrm{t} \mathrm{ha}^{-1}\right)$ aos sete meses e 1,0 (camadas subsuperficiais) a 15,0 $\mathrm{mmol}_{\mathrm{c}} \mathrm{dm}^{-3}$ (40 $\left.\mathrm{t} \mathrm{ha}^{-1}, 0-3 \mathrm{~cm}\right)$ aos doze meses PAB. 
O menor efeito do biossólido nas concentrações de $\mathrm{Ca}$, no solo nãodegradado, explica-se pelos altos conteúdos de Ca presentes na serapilheira e no solo. A serapilheira, em especial, teve importante contribuição para o aporte de Ca no solo, visto a intensa liberação deste nutriente ao solo, dos sete aos doze meses PAB (Tabela 11). No solo degradado ficou evidente a rápida transferência de $\mathrm{Ca}$ do biossólido ao solo, possivelmente pela lixiviação de ânions orgânicos complexados com $\mathrm{Ca}$ e ânions ligantes de acompanhamento, como o $\mathrm{SO}_{4}{ }^{2-}, \mathrm{NO}_{3}{ }^{-}$e o $\mathrm{Cl}^{-}$(Hue \& Licudine, 1999). O efeito mais pronunciado no solo degradado foi devido à presença, neste sistema, de menor conteúdo de nutrientes, em virtude da remoção da serapilheira e do topo do horizonte A (Tabela 7). 


\subsubsection{Magnésio}

No solo não-degradado, o $\mathrm{Mg}$ apresentou comportamento similar ao $\mathrm{Ca}$ na camada 0-3 cm, aos sete meses $\mathrm{PAB}$, mas com menor diferença entre valores médios. Na camada 3-10 cm, houve diminuição linear das concentrações com a aplicação de doses crescentes de biossólido $(\mathrm{P}<0,05)$ (Figura 28). Na camada 0-3 cm, as concentrações de $\mathrm{Mg}$ estão dentro da classe considerada média (4-7 $\mathrm{mmol}_{\mathrm{c}} \mathrm{dm}^{-3}$ ) e, na camada 3-10 cm, estão dentro da classe considerada baixa (0-4 $\left.\mathrm{mmol}_{\mathrm{c}} \mathrm{dm}^{-3}\right)$, para interpretação de recomendação de adubação, segundo Raij et al. (1996). A concentração de $\mathrm{Mg}$ no solo diminuiu com o aumento das doses de biossólido, na camada 3-10 cm do solo, possivelmente pelos mesmos mecanismos supostos ao Ca. Manutenção e, ou deficiência das concentrações de $\mathrm{Mg}$ em sítios florestais fertilizados com biossólido também foi observada por Harrison et al. (1994 e 1996, respectivamente). Balkcon et al. (2001) atribuiram as variações de $\mathrm{Mg}$ trocável aos fatores ambientais, e Harrison et al. (1996) relacionam esta deficiência ao excesso de $\mathrm{H}^{+}$, oriundo de altas taxas de nitrificação, que desloca o $\mathrm{Mg}$ da superfície de troca do solo.

Após doze meses, não houve relação entre as concentrações de $\mathrm{Mg}$ e as doses de biossólido. Nas duas amostragens, a maior média foi obtida no solo com fertilização mineral (tratamento 2), em todas as camadas, com 17,5 (7,63) $\mathrm{mmol}_{\mathrm{c}} \mathrm{dm}^{-3} \mathrm{e}$ 22,5 $(3,27) \mathrm{mmol}_{\mathrm{c}} \mathrm{dm}^{-3}$, na camada $0-3 \mathrm{~cm}$, aos sete e aos doze meses PAB, respectivamente (Figura 28). Estas altas concentrações são atribuídas à aplicação de calcário em superfície.

No solo degradado, na camada 0-3 cm, as concentrações de $\mathrm{Mg}$ aumentaram linearmente em função das doses crescentes de biossólido, nos dois períodos amostrados, com maiores aumentos ocorridos aos sete meses PAB (Figura 29). No entanto, as concentrações de Ca estão dentro da classe considerada baixa (0-4 mmol $\mathrm{dm}^{-3}$ ), de acordo com Raij et al. (1996). Como para o Ca, a serapilheira foi a principal fonte de Mg para o solo, fato também observado por Rocha (2002). 

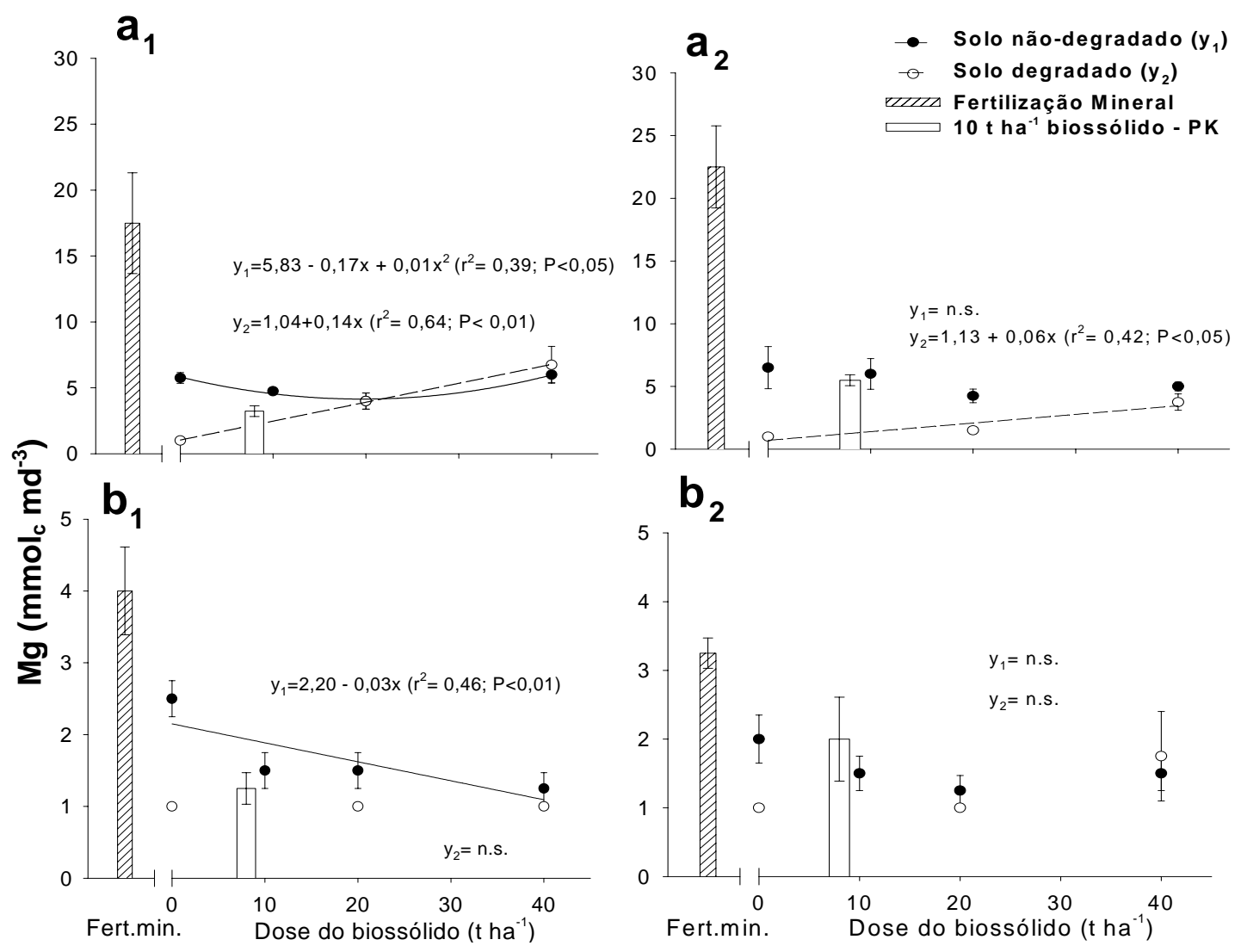

Figura 28- Concentração de Mg (média + erro padrão) aos sete (1) e aos doze meses (2) pós-aplicação do biossólido, nas camadas $0-3$ (a) e $3-10 \mathrm{~cm}$ (b) do solo não-degradado e degradado, nos diferentes tratamentos

\subsubsection{Enxofre}

Assim como o P, as concentrações de $\mathrm{S}^{-\mathrm{SO}_{4}}{ }^{2-}$ aumentaram com as doses crescentes de biossólido, nos dois sistemas de cultivo e nos dois períodos avaliados (Figura 29). De modo geral, os tratamentos que receberam biossólido tiveram concentrações de S acima dos valores considerados adequados por Gonçalves et al. (1996) para a camada 0-20 cm do solo, para cultivos de eucalipto (10,0 $\left.\mathrm{mg} \mathrm{dm}^{-3}\right)$.

No solo não-degradado, a disponibilidade de S no solo aos doze meses foi maior do que aos sete meses $\mathrm{PAB}$, atribuído a mineralização da serapilheira e do biossólido (Tabela 11). Aos doze meses, as intensas taxas de mineralização e de 
lixiviação de $\mathrm{S}$ foram evidenciadas por alterações das concentrações de $\mathrm{SO}_{4}{ }^{2-}$ nos tratamentos que receberam biossólido, a $30 \mathrm{~cm}$ de profundidade, mesmo em um período de menor ocorrência de chuvas (agosto/2002) (Figura 29). Contrariamente, no solo degradado, a maior transferência de $\mathrm{S}$ do biossólido ao solo ocorreu na primeira amostragem (aos sete meses PAB), com manutenção ou diminuição das concentrações na segunda amostragem. Estudos com uso de biossólido, em diferentes formas de aplicação, constataram que a liberação do $\mathrm{S}$ oriundo do biossólido ocorreria mais intensamente nos primeiros sete meses PAB (Silva et al., 2001; Abreu Junior et al., 2001; Vaz \& Gonçalves, 2002; Rocha, 2002). No entanto, o comportamento do S neste estudo reforça a hipótese da atuação da serapilheira como fator de impedimento físico e, ou microbiológico (imobilização temporária) à pronta disponibilização de nutrientes, retendo parte do $\mathrm{S}$ oriundo de compostos sulfurados facilmente decomponíveis. A maior eletronegatividade, as maiores concentrações de MO e de íon fosfato (que ocupam os mesmos sítios de adsorção do $\mathrm{SO}_{4}{ }^{2-}$ ), e o aumento do $\mathrm{pH}$ da camada superficial do solo favorecem a lixiviação de $\mathrm{SO}_{4}{ }^{2-}$ para camadas subsuperficiais. Este efeito pode ser benéfico às culturas susceptíveis ao $\mathrm{Al}$, por possibilitar sua neutralização em subsuperfície. No entanto, no caso do eucalipto, pouco suscetível a toxidez de Al, a lixiviação de grande quantidade de $\mathrm{SO}_{4}{ }^{2-}$ pode estar contribuindo tanto para o aumento de bases em subsuperfície como para a perda de cátions do sistema, em especial o $\mathrm{K}$, possibilitando a ocorrência de desbalanço nutricional. 


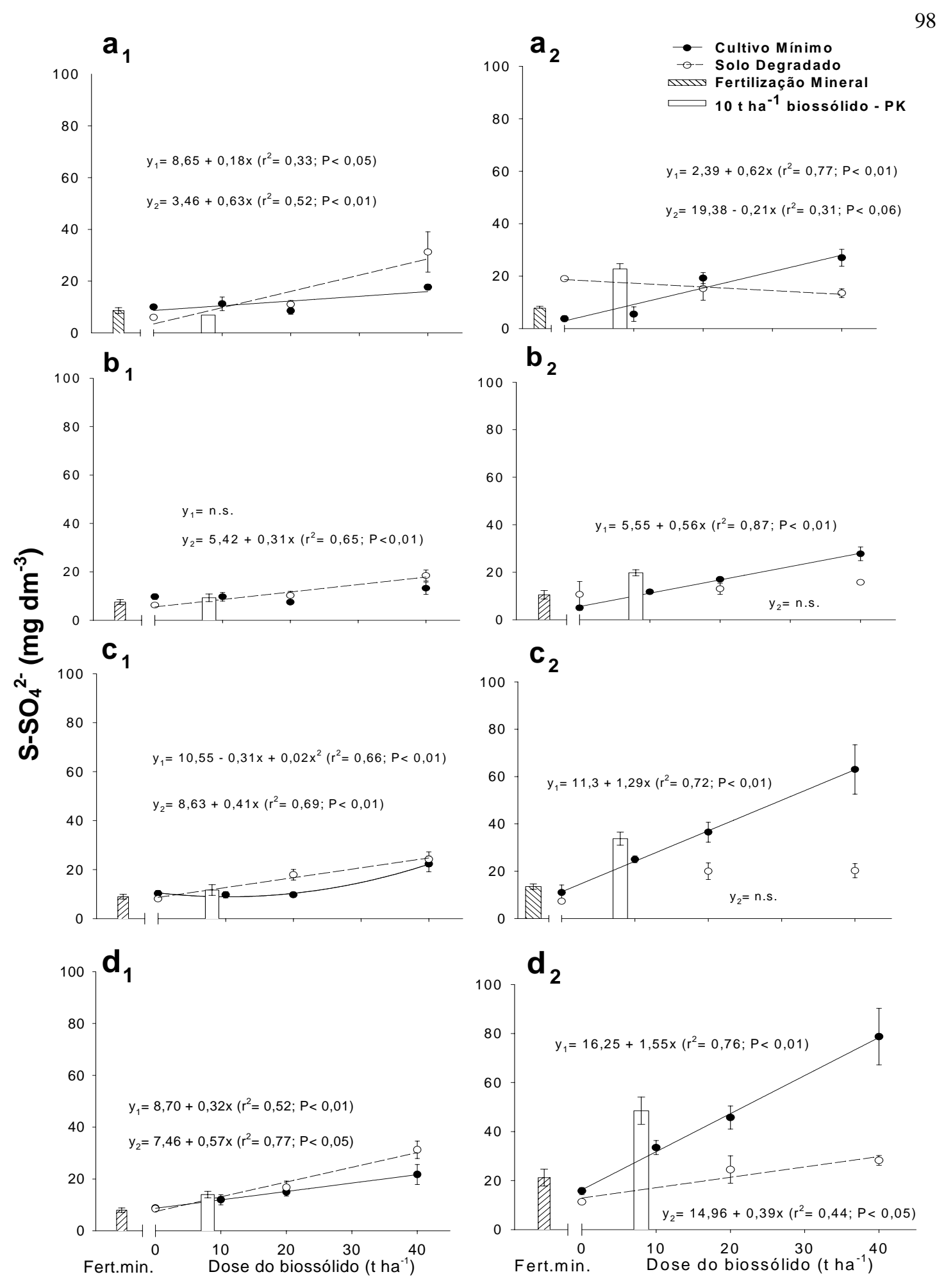

Figura 29- Concentração de S-SO ${ }_{4}^{2-}$ (média \pm erro padrão) aos sete (1) e aos doze (2) meses pós-aplicação do biossólido, nas camadas 0-3 (a), 3-10 (b), 10-20 (c) e 20-30 cm (d) cm do solo nãodegradado e degradado, nos diferentes tratamentos 


\subsection{Nutrição das árvores}

\subsubsection{Nitrogênio}

As concentrações foliares de $\mathrm{N}$ ficaram acima do adequado aos três, aos sete e aos doze meses pós-aplicação do biossólido (PAB) (13-18 $\mathrm{g} \mathrm{kg}^{-1}$, segundo Gonçalves et al., 1996), em todos os tratamentos avaliados (Figura 30). A aplicação do biossólido proporcionou, na fase inicial de crescimento das plantas (até sete meses PAB), aumento na absorção de N, nos dois sistemas de cultivo. Isto ficou evidenciado pelo aumento das concentrações de $\mathrm{N}$ foliar em função das doses crescentes de biossólido, aos três e aos sete meses PAB $(\mathrm{P}<0,05)$ (Figura 30). Efeito similar foi observado por Andrade \& Mattiazzo (2000) e Guedes (2000), em plantio de E. grandis. Aos doze meses $\mathrm{PAB}$, as concentrações de $\mathrm{N}$ diminuíram e não houve relação entre as doses crescentes de biossólido e as concentrações foliares de $\mathrm{N}$, nas duas áreas de cultivo. Contudo, numericamente, infere-se que houve tendência de aumento das concentrações de $\mathrm{N}$ nos tratamentos com 10 e $20 \mathrm{t} \mathrm{ha}^{-1}$ de biossólido, seguido de diminuição. $\mathrm{Na}$ área submetida a cultivo mínimo, as concentrações foliares de $\mathrm{N}$ variaram de $24,3 \pm 0,9$ a $28,0 \pm 1,3 \mathrm{~g} \mathrm{~kg}^{-1} \mathrm{e}$, na área submetida a degradação, as concentrações variaram de 22,8 $\pm 1,7$ a 24,6 $\pm 2,2 \mathrm{~g} \mathrm{~kg}^{-1}$ (Figura 30). Esta diminuição, dos sete aos doze meses $\mathrm{PAB}$, está relacionada à menor disponibilidade de $\mathrm{N}$ nos resíduos e no solo, à menor temperatura e precipitação na época avaliada (agosto/2002) e ao efeito de diluição (devido à expansão foliar).

As altas concentrações foliares, com pouca diferença entre os tratamentos avaliados, evidenciam a contribuição da serapilheira e da MO do solo não-degradado na disponibilização de $\mathrm{N}$ às plantas. No solo degradado, com a remoção do topo do horizonte A, a perturbação e a exposição (propícia ao aumento da temperatura e da umidade) da camada subjacente deve ter intensificado a mineralização da MO do solo, suprindo bem as plantas com $\mathrm{N}$ na fase inicial de crescimento. Por este motivo, o crescimento inicial das plantas foi maior nestas condições (primeiros três meses de cultivo; observações de campo). 


\subsubsection{Fósforo}

As concentrações crescentes de P-resina em função do aumento das doses de biossólido resultaram em aumento linear das concentrações foliares de $\mathrm{P}$, nos dois sistemas de cultivo, aos sete meses $\mathrm{PAB}(\mathrm{P}<0,05)$ (Figura 30). Resultado semelhante foi obtido por Berton et al. (1989) com cultivo de milho em cinco solos do Estado de São Paulo, por Da Ros et al. (1993) com cultivo do milheto em um Argissolo VermelhoAmarelo e por Prescott et al. (1993) em casa de vegetação, com mudas das espécies florestais Pseudotsuga menziesii e Picea sitchensis. Aos doze meses, apesar das altas concentrações de P-resina com a aplicação de biossólido, não houve relação entre estas e as concentrações foliares de P. As menores concentrações de P nesta idade estão relacionadas a menor absorção de P (baixa umidade), na época avaliada (agosto/2002), e ao efeito de diluição, causada pela rápida expansão da área e a alocação de P para outras partes da planta. Guedes (2000) e Vaz \& Gonçalves (2002), estudando o efeito de doses crescentes de biossólido condicionado com cal no crescimento inicial de E. grandis, só observaram considerável aumento nas concentrações foliares de $\mathrm{P}$ aos doze meses PAB. Este efeito foi atribuído à menor solubilidade deste tipo de biossólido ao longo do período de estiagem que precedeu a avaliação.

O tratamento que recebeu $10 \mathrm{t} \mathrm{ha}^{-1}$ de biossólido, sem suplementação de $\mathrm{P}$ e K, apresentou concentração média de $\mathrm{P}$ foliar similar ao tratamento que recebeu igual quantidade de biossólido mais suplementação de P e K (Figura 30).

\subsubsection{Potássio}

No solo não-degradado, aos sete meses $\mathrm{PAB}$, não houve relação entre as concentrações foliares de $\mathrm{K}$ e a aplicação de biossólido (Figura 30). O tratamento com fertilização mineral apresentou a maior concentração foliar de $\mathrm{K}\left(10,2 \pm 1,3 \mathrm{~g} \mathrm{~kg}^{-1}\right)$. Este tratamento e o que recebeu $10 \mathrm{t} \mathrm{ha}^{-1}$ de biossólido + PK foram os únicos a apresentarem concentrações foliares de K consideradas adequadas por Gonçaves et al. (1996) (9 a $13 \mathrm{~g}$ 
$\left.\mathrm{kg}^{-1}\right)$. Os demais tratamentos apresentaram concentrações foliares de $\mathrm{K}$ abaixo do nível de suficiência à produtividade da cultura, com valores médios variando de 6,6 (1,1) a 7,4 $(1,4) \mathrm{g} \mathrm{kg}^{-1}$. Aos doze meses PAB, nos tratamentos sob solo não-degradado, houve diminuição linear das concentrações foliares de $\mathrm{K}$ em função das doses de biossólido, $\left(9,1 \pm 0,5\right.$ a 7,8 $\left.\pm 0,1 \mathrm{~g} \mathrm{~kg}^{-1}\right)(\mathrm{P}<0,01)$, resultado concordante com Berton et al. (1989) em cultivo de milho. Nesta idade, o tratamento com fertilização mineral também apresentou a maior média $\left(9,3 \pm 0,6 \mathrm{~g} \mathrm{~kg}^{-1}\right)$, e o tratamento com $10 \mathrm{t} \mathrm{ha}^{-1}$ sem fertilização de $\mathrm{P}$ e $\mathrm{K}$, a menor média de $\mathrm{K}\left(6,3 \pm 06 \mathrm{~g} \mathrm{~kg}^{-1}\right)$. Destes, apenas os tratamentos Controle (1) e submetido à fertilização mineral (2) apresentaram concentrações foliares de $\mathrm{K}$ em níveis adequados. Em povoamentos de E. grandis que receberam doses crescentes de biossólido, Vaz \& Gonçalves (2002) atribuíram a presença de maior $\mathrm{K}$ foliar no tratamento de menor produtividade (Controle) ao efeito de concentração. Entretanto, no presente experimento, as plantas apresentaram sintomas visuais de deficiência de $\mathrm{K}^{3}$ ao longo dos sete primeiros meses de cultivo. No solo degradado, estatisticamente, nas duas idades avaliadas, não houve relação entre as doses crescentes de biossólido e as concentrações de K. Contudo, numericamente, observou-se tendência à diminuição de $\mathrm{K}$ foliar com o aumento da dose (Figura 30). Maiores concentrações foram observadas aos doze meses PAB $\left(5,5 \pm 0,2\right.$ a $6,1 \pm 0,7 \mathrm{mg} \mathrm{kg}^{-1}$ aos sete meses e 7,6 $\pm 0,9$ a 8,6 $\pm 0,5 \mathrm{~g} \mathrm{~kg}^{-1}$ aos doze meses), possivelmente devido as maiores concentrações de $\mathrm{K}$ trocável (Tabela 18), aumentadas via fertilização potássica de cobertura. Mesmo assim, nas duas idades, as concentrações foliares de K estiveram abaixo dos valores de suficiência para adequada produtividade da cultura (Gonçalves et al, 1996). A deficiência de K mediante aplicação de biossólido foi observada por Pietz et al. (1989a) em gramíneas cultivadas em rejeitos de carvão. Além da lixiviação de K, a diminuição da absorção de $\mathrm{K}$ pode também ser devido à ação competitiva do $\mathrm{NH}_{4}{ }^{+}$ (Nielsen \& Hansen, 1984; Marschner, 1986), em excesso nos tratamentos que receberam biossólido.

3 Avermelhamento das bordas, progredindo em direção ao centro das folhas; secamento da ponta das folhas nos casos mais severos de deficiência. 

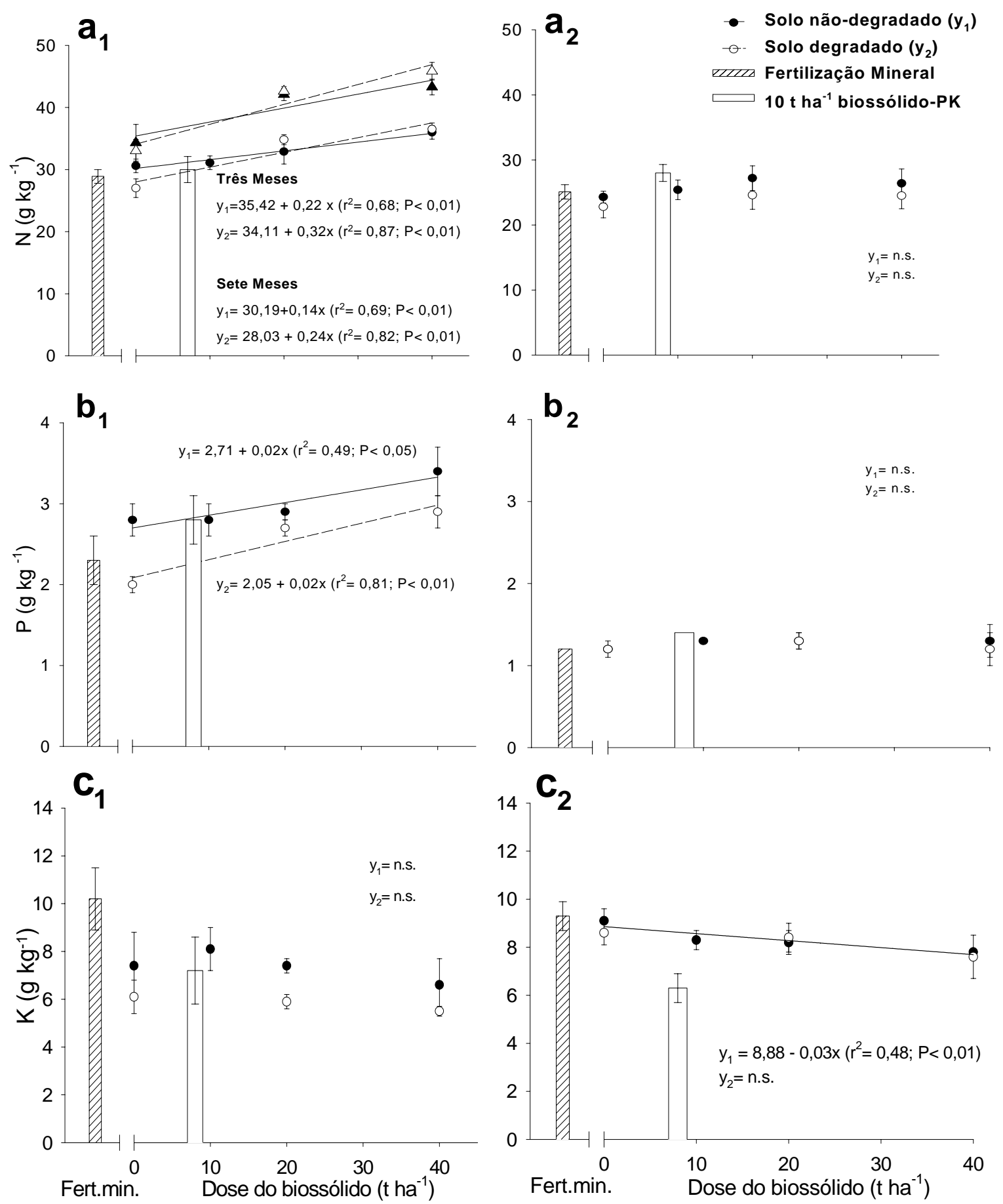

Figura 30- Concentrações foliares de N (a) aos três meses, de N (a), de K (b) e de P (c) (média \pm erro padrão) aos sete (1) e aos doze meses (2) pós-aplicação do biossólido, nos tratamentos em solo não-degradado e degradado 


\subsubsection{Cálcio e Magnésio}

Aos sete meses $\mathrm{PAB}$, não houve relação entre a concentração foliar de $\mathrm{Ca}$ e as doses de biossólido, nos dois sistemas de cultivo (Figura 31). Nesta idade, as plantas apresentaram concentrações adequadas $\left(5,7 \pm 0,3\right.$ a $\left.7,1 \pm 0,6 \mathrm{~g} \mathrm{~kg}^{-1}\right)$ à nutrição das árvores, de acordo com Gonçalves et al. (1996) (6 a $\left.10 \mathrm{~g} \mathrm{~kg}^{-1}\right)$. Contudo, no cultivo em solo não-degradado, houve tendência à diminuição das concentrações de $\mathrm{Ca}$ nos tratamentos com 10 e $20 \mathrm{t} \mathrm{ha}^{-1}$ de biossólido, seguido de aumento, e, no solo degradado, aumento das concentrações de Ca nos tratamentos com biossólido. Estas tendências são condizentes com os resultados observados para as concentrações de Ca no solo, nos dois sistemas de cultivo (Figura 27). A não diferença estatística entre tratamentos, apesar das variações observadas no solo, pode ser explicada pela capacidade finita de absorção de cátions (Nielsen \& Hansen, 1984) ou pela possível desordem nutricional ocasionada pela menor seletividade das plantas à absorção em ambientes com alta concentração de nutrientes (Marschner, 1986). A absorção de Ca pode ser diminuída em maiores concentrações de $\mathrm{N}^{-} \mathrm{NH}_{4}{ }^{+}$(mais rapidamente absorvido pela planta), em virtude da alta atividade do $\mathrm{H}^{+}$e da indução ao aumento na permeabilidade da plasmalena (Locatelli et al., 1984; Mengel \& Kirkby, 1987).

Nos dois sistemas de cultivo, após 12 meses de aplicação do biossólido, houve diminuição de até $50 \%$ das concentrações de Ca observadas no período anterior de amostragem, as quais, nesta idade, ficaram abaixo do limite menor da faixa crítica à cultura de eucalipto. Esta diminuição da concentração foliar de Ca está primariamente associada ao efeito de diluição (taxa de aumento de biomassa maior do que da taxa de absorção) e, secundariamente, associada à diminuição da absorção de $\mathrm{Ca}$, devida aos processos de disponibilização deste nutriente (mineralização de MO e transferência) e, ou inibição da absorção por excesso de $\mathrm{N}^{-\mathrm{NH}_{4}}{ }^{+}$no solo ou $\mathrm{Zn}$ (em grande quantidade no biossólido), os quais deslocam o Ca nos sítios de troca dos vasos condutores do xilema (Malavolta, 1980). Nesta idade, apenas no solo degradado houve efeito do biossólido sobre as concentrações foliares de $\mathrm{Ca}$, com aumento linear em função das doses aplicadas. 
As concentrações de $\mathrm{Mg}$ aumentaram com a aplicação de doses crescentes de biossólido, apenas no solo degradado, constatado aos sete meses de idade $(\mathrm{P}<0,01)$ (Figura 31). As concentrações estão abaixo da faixa considerada adequada $(3,5$ a $5,0 \mathrm{~g} \mathrm{~kg}^{-1}$ de $\mathrm{Mg}$ ) à nutrição das árvores (Gonçalves et al., 1996). O aumento das concentrações foliares de $\mathrm{Mg}$ está condizente com o aumento das concentrações de $\mathrm{Mg}$ na camada 0-3 cm, no mesmo período. Efeito semelhante foi observado por Berton et al. (1989), com milho (biossólido incorporado ao solo), e por Silva et al. (1998), com canade-açúcar, em um Nitossolo que recebeu de $30 \mathrm{t} \mathrm{ha}^{-1}$ de biossólido no sulco de plantio. No solo não-degradado, houve relação quadrática entre as concentrações de $\mathrm{Mg}$ e as doses de biossólido, com pequena diminuição das concentrações foliares de $\mathrm{Mg}$ até a dose $20 \mathrm{tha}^{-1}$, seguida de aumento. Estes resultados são proporcionais às concentrações de Mg trocável nas camadas 0-3 e 3-10 cm do solo (Figura 29). Aos doze meses, não houve alterações significativas das concentrações de $\mathrm{Mg}$ foliar nos dois sistemas de cultivo, mesmo com aumento das concentrações de Mg trocável, no solo degradado.

\subsubsection{Enxofre}

Apesar dos aumentos das concentrações de $\mathrm{S}_{-} \mathrm{SO}_{4}{ }^{2-}$ no solo com a aplicação de biossólido, apenas no solo degradado este efeito resultou em aumento das concentrações foliares de $\mathrm{S}$, aos sete meses $\mathrm{PAB}$ (Figura 31). Aos doze meses PAB, não houve relações significativas entre as doses de biossólido e as concentrações foliares de $\mathrm{S}$, nos dois sistemas de cultivo. Todos os valores observados nos solos degradado e nãodegradado, e nos dois períodos avaliados, estiveram dentro dos limites considerados adequados (1,5-2,5 $\left.\mathrm{g} \mathrm{kg}^{-1}\right)$ por Gonçalves et al. (1996) para povoamentos de E. grandis com alta produtividade de madeira. O não aumento das concentrações de $\mathrm{S}$ foliar em resposta ao aumento do $\mathrm{S}_{-} \mathrm{SO}_{4}{ }^{2-}$ no solo pode estar relacionado ao alto conteúdo de $\mathrm{MO}$ mineralizável no solo e à grande eficiência do E. grandis na absorção de enxofre (Furtini Neto et al., 1990). A boa disponibilidade de $\mathrm{S}_{-} \mathrm{SO}_{4}{ }^{2-}$ pode ter aumentado as concentrações de clorofila e favorecido a formação e a maior retenção de folhas, 
contribuindo para a diminuição da velocidade de crescimento das árvores (Furtini Neto et al., 1990).
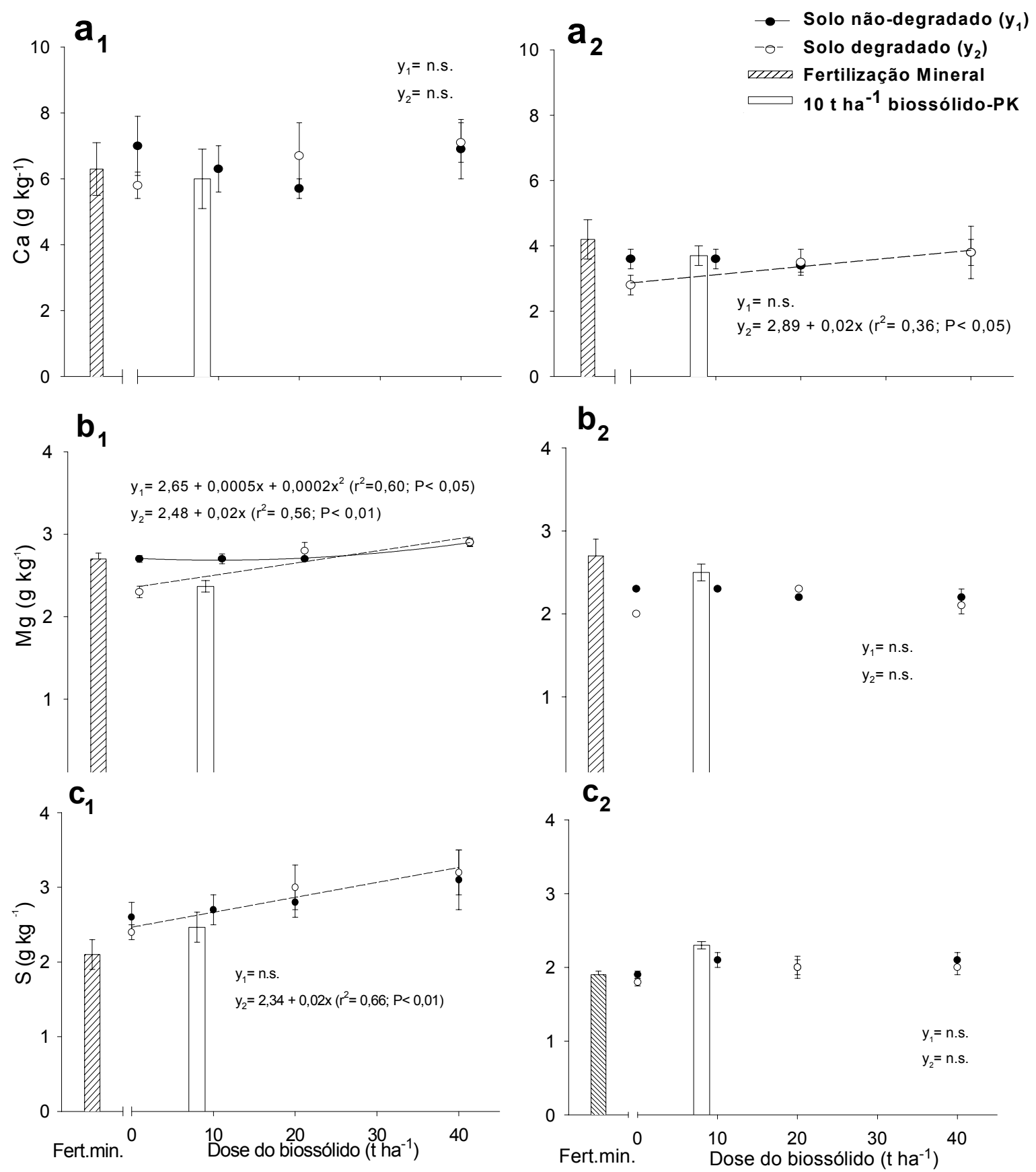

Figura 31- Concentrações foliares de $\mathrm{Ca}(\mathrm{a}), \mathrm{de} \mathrm{Mg}(\mathrm{b})$ e de $\mathrm{S}$ (c) (média \pm erro padrão) aos sete (1) e aos doze (2) meses pós-aplicação do biossólido, nos tratamentos em solo não-degradado e degradado 


\subsection{Crescimento das árvores}

Em observações de campo, não houve diferenças entre os tratamentos no tocante ao crescimento das plantas no solo não-degradado, nos três primeiros meses pósaplicação do biossólido (PAB) (Figura 33a). Isto é devido à fase de adaptação das plantas no campo e à maior disponibilidade de nutrientes neste sistema de manejo (mineralização da MO da serapilheira e da camada superficial do solo). Após esta fase, com o aumento das chuvas e da temperatura do ar (a partir de novembro de 2001) (Figura 2), as diferenças entre tratamentos ficaram evidentes. O biossólido aumentou o crescimento das árvores nos sete meses iniciais $\mathrm{PAB}$, nos dois sistemas de cultivo (Figura 32, 34 e 35). O aumento da disponibilidade de nutrientes via mineralização da MO, diferenciada segundo a quantidade de biossólido nos tratamentos, apresenta-se como a causa mais plausível deste efeito. Para a variável altura das plantas, houve aumento linear em função das doses crescentes de biossólido $(\mathrm{P}<0,01)$ e, para a variável DAP, efeito quadrático $(\mathrm{P}<0,05)$, com valores crescentes até a dose $20 \mathrm{t} \mathrm{ha}^{-1} \mathrm{de}$ biossólido, seguido de ligeiro declínio (Figura 32). Aos doze meses PAB, não houve efeito significativo do biossólido no crescimento das árvores em solo não-degradado (Figura 32). O mais provável é que a diminuição das chuvas e da temperatura (diminuição da mineralização da $\mathrm{MO}$ ) neste período tenha sido o fator que mais contribuiu para a diminuição (e igualamento) das pequenas diferenças de crescimento entre tratamentos observados no período anterior, apesar do aumento das concentrações de $\mathrm{P}$ e $\mathrm{S}$ no solo (Figuras 25 e 29).

O tratamento que recebeu só fertilização mineral apresentou crescimento similar ao do tratamento que recebeu $10 \mathrm{t} \mathrm{ha}^{-1}$ de biossólido + PK (Figura 32). Isto evidencia a eficiência do biossólido como fonte de nutrientes, se suplementado com P e K. A não suplementação destes nutrientes via fertilização mineral diminuiu a taxa inicial de crescimento da cultura (tratamento 6, que recebeu $10 \mathrm{t} \mathrm{ha}^{-1}$ de biossólido - PK). Aparentemente este efeito foi agravado pelo excesso de nutrientes antagônicos ao $\mathrm{P}$ ( $\mathrm{Zn}$, por exemplo) (Benton \& Jones Jr., 1996), e pela lixiviação de K. Ainda assim, o DAP 
das árvores neste tratamento, aos 22 meses $\mathrm{PAB}$, foi semelhante aos tratamentos que receberam suplementação de $\mathrm{P}$ e $\mathrm{K}$.

No solo degradado, houve aumento da altura aos sete e aos doze meses $\mathrm{PAB}$, e do DAP em todas as idades avaliadas, em função das doses crescentes de biossólido (Figuras 32, 33B, 34 e 36). Neste caso, os efeitos da aplicação de biossólido foram evidentes desde o período de estabelecimento das plantas (primeiros três meses PAB). Observou-se, neste período, que as mudas eram maiores e mais vigorosas do que as estabelecidas no solo não-degradado, provavelmente devido ao processo mais rápido de transferência de nutrientes ao solo sem serapilheira. Este maior crescimento inicial não prevaleceu após o período das chuvas, pois o crescimento das árvores plantadas no solo não-degradado foi maior nos tratamentos com biossólido. Entretanto, na dose $40 \mathrm{t}$ $\mathrm{ha}^{-1}$ de biossólido $+\mathrm{PK}$, não houve diferenças de crescimento das árvores em função do sistema de cultivo (Figura 32). Ou seja, a aplicação desta alta dose de biossólido compensou a remoção dos $20 \mathrm{~cm}$ superiores do horizonte A. 

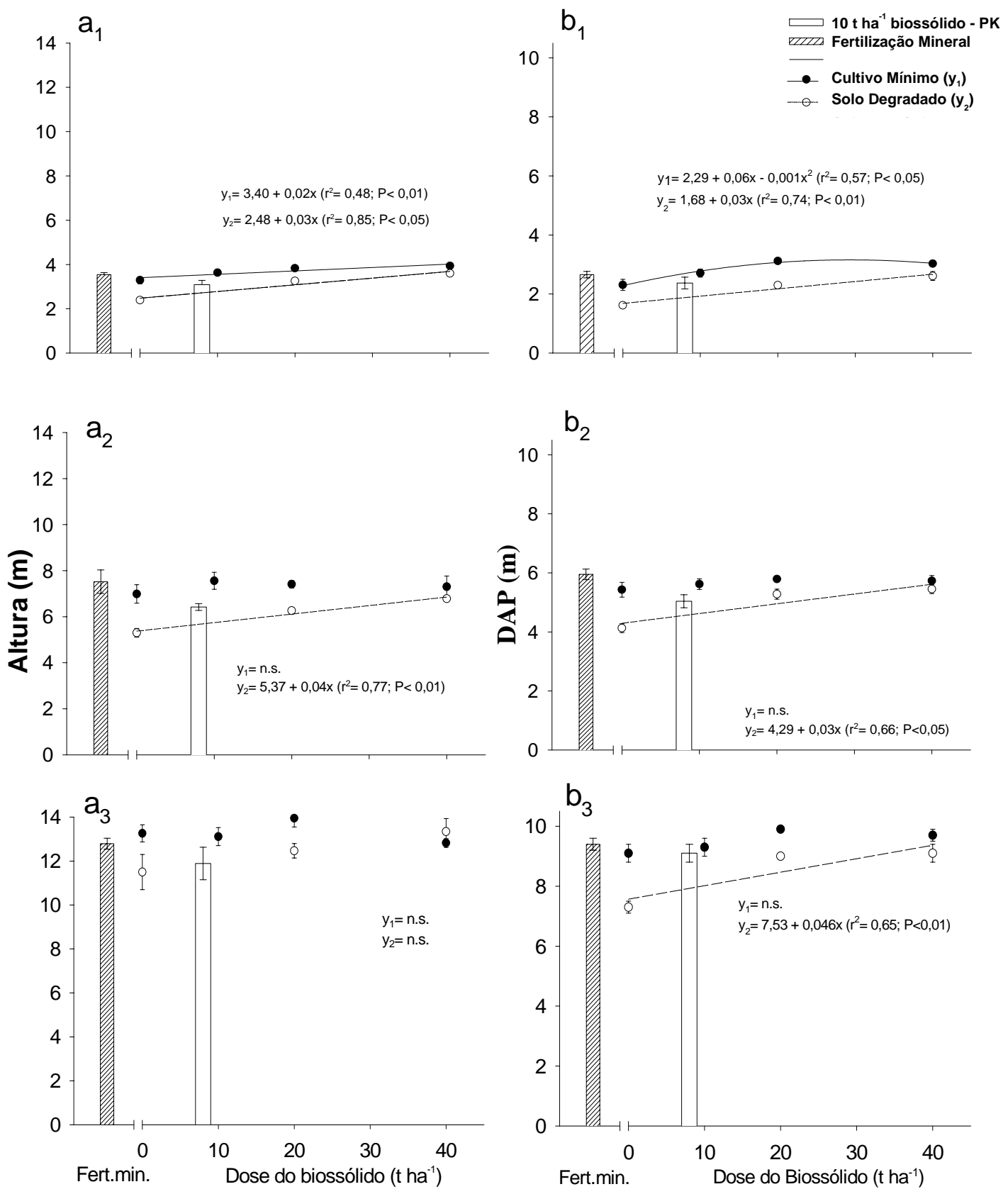

Figura 32. Altura (a) e diâmetro à altura do peito (DAP) (b) das árvores aos sete (1), aos doze (2) e aos vinte e dois meses (3) pós-aplicação do biossólido, em solo não-degradado e degrado, nos diferentes tratamentos 


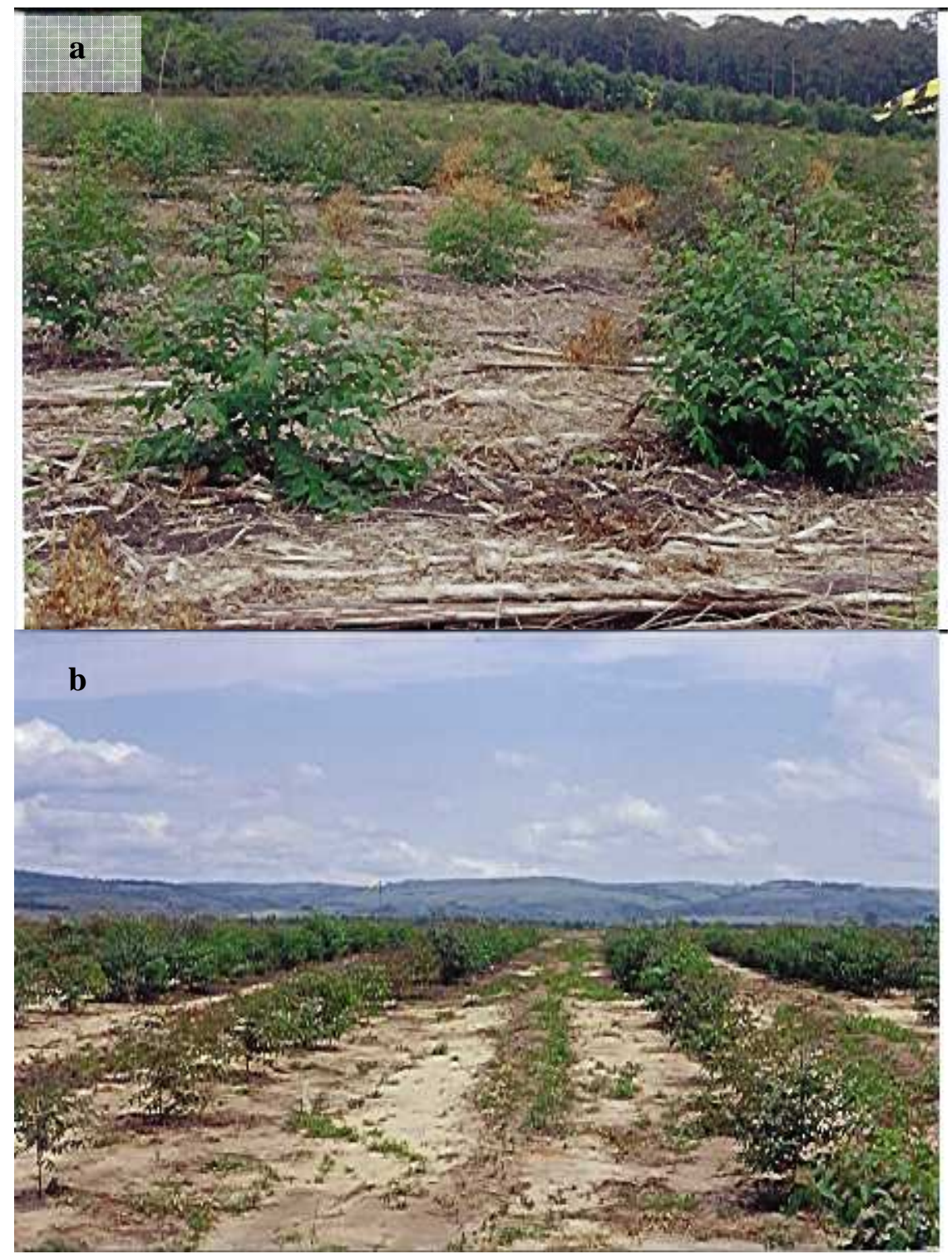

Figura 33- Eucalyptus grandis aos três meses pós-aplicação do biossólido, no solo não-degradado que recebeu $20 \mathrm{t} \mathrm{ha}^{-1}$ de biossólido mais PK (tratamento 4) (a) e no solo degradado, sem aplicação de biossólido (tratamento 7) (b) 

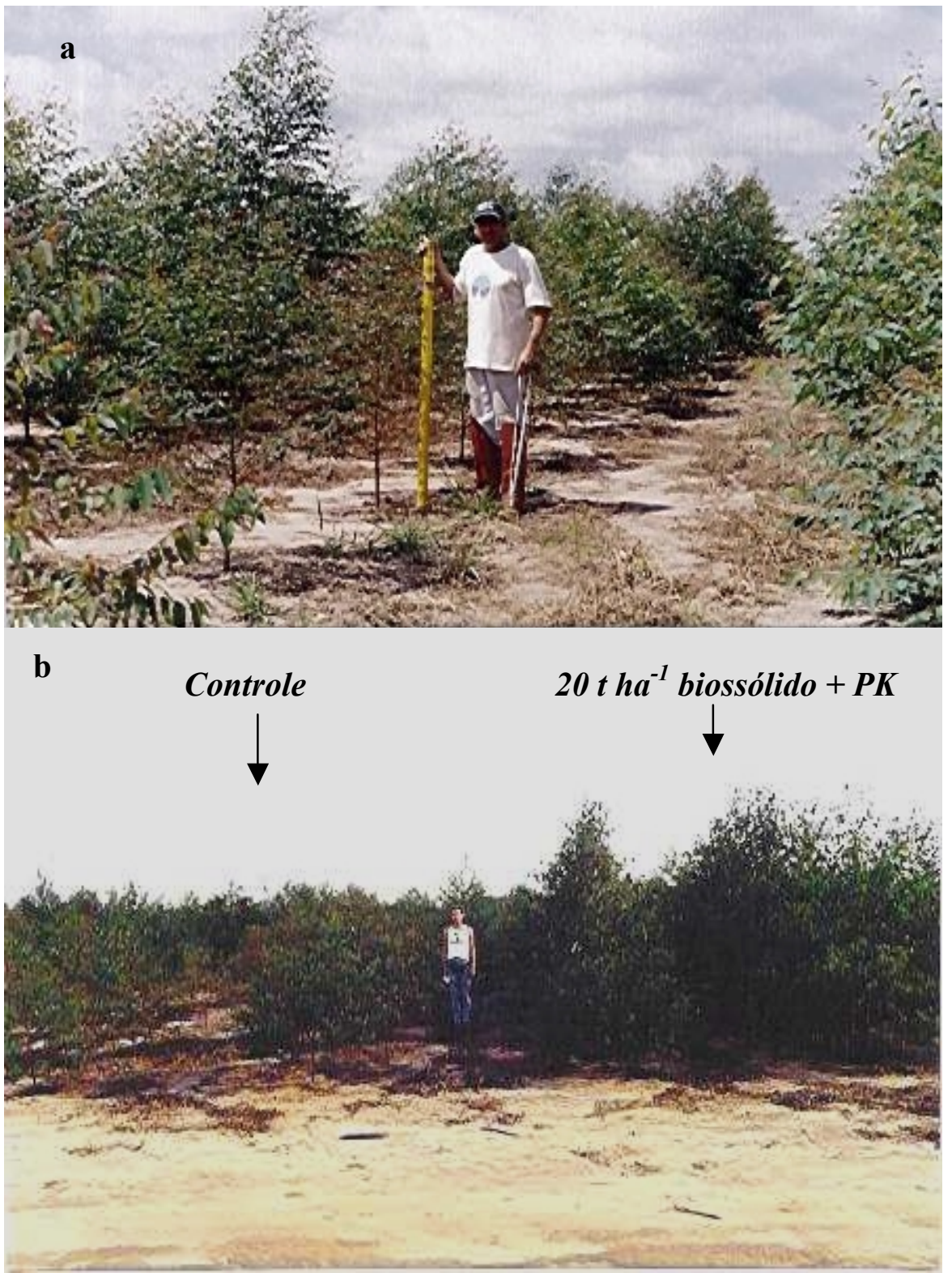

Figura 34- Eucalyptus grandis aos sete meses pós-aplicação do biossólido, no solo degradado sem biossólido (tratamento 7) (a); solo degradado sem aplicação de biossólido (tratamento 7, à esquerda) e que recebeu $20 \mathrm{t} \mathrm{ha}^{-1}$ de biossólido mais $\mathrm{PK}$ (tratamento 8, à direita) (b) 

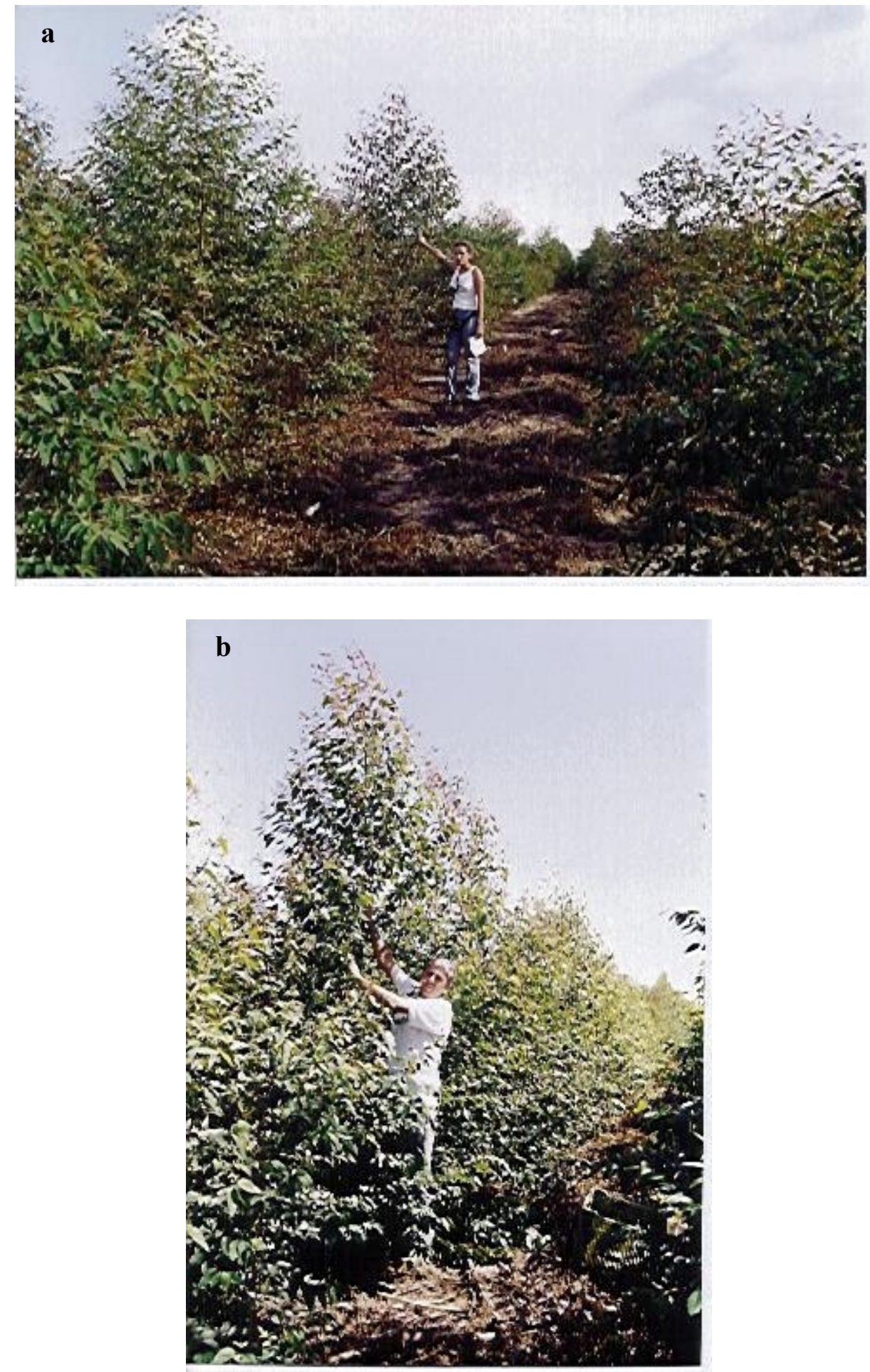

Figura 35- Eucalyptus grandis aos sete meses pós-aplicação do biossólido, no solo não-degradado sem aplicação de biossólido (Controle, tratamento 1) (a), e que recebeu $20 \mathrm{tha}^{-1}$ de biossólido mais PK (tratamento 4) (b) 

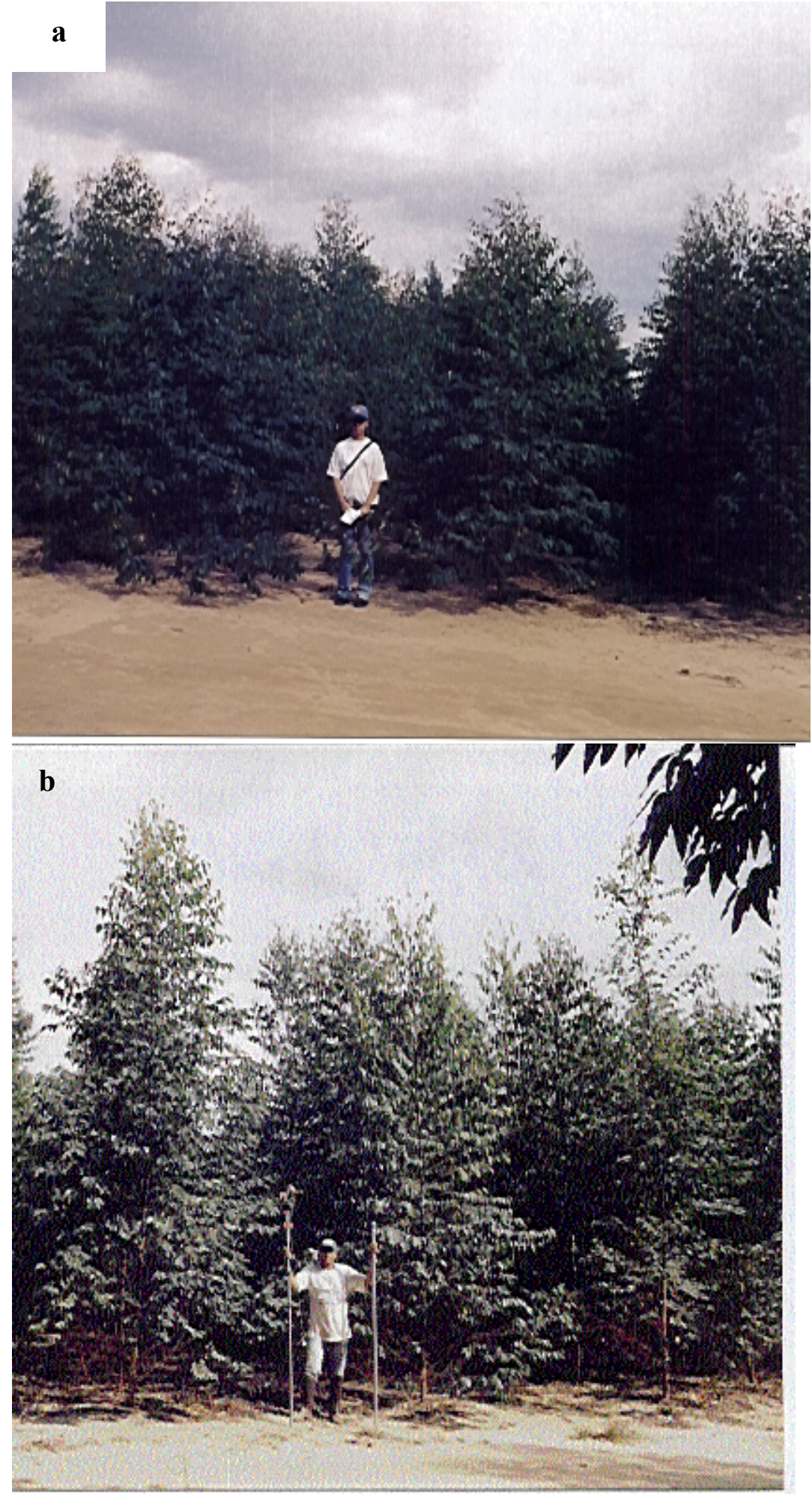

Figura 36- Eucalyptus grandis aos doze meses pós-aplicação do biossólido, no solo degradado sem aplicação do biossólido (Controle, tratamento 7) (a) e que recebeu $20 \mathrm{t} \mathrm{ha}^{-1}$ de biossólido mais PK (tratamento 8) (b) 
Por meio de análises de regressões múltiplas, obteve-se equações em que as variáveis dependentes altura e DAP apresentaram relações com as concentrações de alguns macronutrientes nas folhas, nos tratamentos em solo não-degradado (1, 3, 4 e 5) e sob solo degradado (7, 8 e 9). Em todas as equações, foram obtidos elevados coeficientes de determinação, indicando bom ajuste dos modelos e o efeito aditivo de alguns nutrientes (Tabelas 15 a 18).

Aos sete meses de idade, $99,4 \%$ e 99,6\% da variância da altura das árvores foram associadas à concentração de $\mathrm{N}$, no solo não-degradado e degradado, respectivamente (Tabelas 15 a 18). Nesta mesma idade, a variância do DAP foi 93,6 e 98,5\% explicada pelo aumento nas concentrações de $\mathrm{N}$ nas folhas, no solo nãodegradado e degradado, respectivamente. Estes resultados estão de acordo com a intensa mineralização de $\mathrm{N}$ do biossólido, e com os aumentos das concentrações foliares destes nutrientes no período citado.

Aos doze meses de idade, $99 \%$ da variância da altura das árvores, no solo não-degradado, foi associada à concentração de $\mathrm{Mg}$ (Tabelas 15 e 16) e, no solo degradado, 98\% da variância da altura foi associada à concentração de $\mathrm{N}$ (Tabelas $17 \mathrm{e}$ 18). Nesta mesma idade, a variância do DAP foi $99,1 \%$ e $98 \%$ explicada pelas concentrações de $\mathrm{N}$, no sistema de cultivo mínimo e no solo degradado, respectivamente (Tabelas 15 a 18).

Os modelos obtidos para as variáveis altura e DAP, nas duas idades e nos dois sistemas de cultivo (exceto a altura aos doze meses P.A.B, no solo não-degradado) são condizentes com os resultados apresentados por Louw (1997), que obteve relações entre as concentrações foliares de $\mathrm{N}$ e $\mathrm{P}$ e a produtividade do E. grandis (20 anos de idade), com Andrade \& Mattiazzo (2000) e com Bramryd (2001), que consideraram a maior absorção e assimilação de $\mathrm{N}$ pelas árvores o principal diferencial de crescimento das árvores fertilizadas com biossólido. No entanto, a mineralização de grande quantidade de $\mathrm{N}$ presente na serapilheira e no solo, no sistema de cultivo mínimo (Figuras 10 e 15), foi suficiente ao suprimento da demanda média de $\mathrm{N}$ dos povoamentos de eucalipto, fato que explica as relações entre o crescimento das árvores e as concentrações foliares de $\mathrm{Mg}$, no solo não-degradado, aos doze meses PAB. 
Apesar da baixa demanda de $\mathrm{Mg}$ trocável pelo eucalipto em seu crescimento inicial, o crescimento das árvores pode ter sido limitado pela diminuição da absorção deste nutriente pelas árvores (Novais et al., 1990), aos doze meses PAB, dedução inferida a partir das baixas concentrações foliares, próximas ou abaixo do limite menor da faixa crítica à cultura de eucalipto (Gonçalves et al., 1996). Barros \& Novais (1996) afirmam que eucaliptais com alto coeficiente de utilização de nutrientes podem ser susceptíveis à falta de Mg. Provavelmente, este efeito ocorra devido à competição antagônica entre cátions no processo de absorção. 
Tabela 15. Análise de variância da regressão múltipla para as variáveis dependentes altura e diâmetro à altura do peito (DAP), aos sete e aos doze meses pós-aplicação do biossólido (PAB), nos tratamentos em solo não-degradado com suplementação de P e K

\begin{tabular}{|c|c|c|c|c|c|c|}
\hline FV & SQ & g.l. & Q.M. & $\mathbf{F}$ & probab. & $\mathbf{R}^{2}$ \\
\hline & & & & & & $\%$ \\
\hline \multicolumn{7}{|c|}{ Altura - sete meses $\mathbf{P A B}^{(1)}$} \\
\hline $\mathrm{N}$ & 216,147 & 1 & 216,147 & 3094,40 & $<0,01$ & 99,4 \\
\hline $\mathrm{P}$ & 0,287 & 1 & 0,287 & 4,10 & 0,06 & 0,1 \\
\hline Resíduo & 0,978 & 14 & & & & \\
\hline Total & 217,411 & 16 & & & & 99,6 \\
\hline \multicolumn{7}{|c|}{ Altura - doze meses PAB ${ }^{(2)}$} \\
\hline $\mathrm{Mg}$ & 856,469 & 1 & 856,469 & 1526,13 & $<0,01$ & 99,0 \\
\hline Resíduo & 8,41802 & 15 & & & & \\
\hline Total & 864,887 & 16 & & & & 99,0 \\
\hline \multicolumn{7}{|c|}{ DAP - sete meses PAB ${ }^{(3)}$} \\
\hline $\mathrm{N}$ & 125,612 & 1 & 125,61 & 2165,41 & $<0,01$ & 93,6 \\
\hline $\mathrm{P}$ & 0,23662 & 1 & 0,2366 & 4,08 & 0,07 & 5,5 \\
\hline $\mathrm{Ca}$ & 0,686394 & 1 & 0,6864 & 11,83 & $<0,01$ & 0,1 \\
\hline $\mathrm{S}$ & 0,37821 & 1 & 0,3781 & 5,65 & 0,03 & 0,3 \\
\hline Resíduo & 0,696 & 12 & & & & \\
\hline Total & 127,559 & 16 & & & & 99,5 \\
\hline \multicolumn{7}{|c|}{ DAP - doze meses PAB ${ }^{(4)}$} \\
\hline $\mathrm{N}$ & 507,018 & 1 & 507,018 & 1709,33 & $<0,01$ & 99,1 \\
\hline Resíduo & 4,44928 & 15 & & & & \\
\hline Total & 511,467 & 16 & & & & 99,1 \\
\hline
\end{tabular}

${ }^{(1)}$ Erro padrão do valor estimado: 0,26429; Erro absoluto da média: 0,19997; Durbin-Watson: 2,3723;

${ }^{(2)}$ Erro padrão do valor estimado: 0,749134; Erro absoluto da média: 0,600987; Durbin-Watson: 1,69391;

${ }^{(3)}$ Erro padrão do valor estimado: 0,24085; Erro absoluto da média: 0,173948; Durbin-Watson: 3,05725;

${ }^{(4)}$ Erro padrão do valor estimado: 0,544627; Erro absoluto da média: 0,461635; Durbin-Watson: 2,39214.

Tabela 16. Equações de regressão múltipla que relacionam a altura e o diâmetro à altura do peito (DAP) das árvores com as concentrações de macronutrientes foliares aos sete e aos doze meses pósaplicação do biossólido, nos tratamentos em solo não-degradado com suplementação de $\mathrm{P}$ e K

\begin{tabular}{clccc}
\hline Época & Equação & $\mathbf{R}^{\mathbf{2}}$ & Signif. \\
\hline & & Altura & $\%$ & \\
& & & & \\
Sete meses & $\mathbf{y}=0,191815 \mathbf{N}-0,873247 \mathbf{P}$ & & 99,6 & $<0,01$ \\
Doze meses & $\mathbf{y}=3,22829 \mathbf{M g}$ & 99,0 & $<0,01$ \\
& & $\mathbf{D A P}$ & & \\
Sete meses & $\mathbf{y}=0,160719 \mathbf{N}-0,823489 \mathbf{P}-0,271639 \mathbf{C a}+0,621079 \mathbf{S}$ & 99,5 & $<0,01$ \\
Doze meses & $\mathbf{y}_{\mathbf{2}}=0,21738 \mathbf{N}$ & 99,1 & $<0,01$ \\
\hline
\end{tabular}


Tabela 17. Análise de variância da regressão múltipla para as variáveis dependentes altura e diâmetro à altura do peito (DAP), aos sete e aos doze meses pósaplicação do biossólido (PAB), nos tratamentos em solo degradado

\begin{tabular}{|c|c|c|c|c|c|c|}
\hline FV & SQ & g.l. & Q.M. & $\mathbf{F}$ & Probab. & $\mathbf{R}^{2}$ \\
\hline & & & & & & $\%$ \\
\hline \multicolumn{7}{|c|}{ Altura - sete meses PAB ${ }^{(1)}$} \\
\hline $\mathrm{N}$ & 116,774 & 1 & 116,774 & 8335,98 & $<0,01$ & 99,6 \\
\hline $\mathrm{P}$ & 0,32893 & 1 & 0,32893 & 23,48 & $<0,01$ & 0,2 \\
\hline $\mathrm{Ca}$ & 0,134773 & 1 & 0,13473 & 9,62 & 0,01 & 0,1 \\
\hline Resíduo & 0,126076 & 9 & & & & \\
\hline Total & 117,363 & 12 & & & & 99,9 \\
\hline \multicolumn{7}{|c|}{ Altura - doze meses PAB ${ }^{(2)}$} \\
\hline $\mathrm{N}$ & 446,949 & 1 & 446,949 & 1865,05 & $<0,01$ & 97,5 \\
\hline $\mathrm{P}$ & 0,9146 & 1 & 0,9146 & 3,82 & 0,09 & 0,2 \\
\hline $\mathrm{Ca}$ & 2,0087 & 1 & 2,0087 & 8,38 & 0,02 & 0,4 \\
\hline $\mathrm{Mg}$ & 2,0892 & 1 & 2,0892 & 8,72 & 0,02 & 0,5 \\
\hline Resíduo & 1,917 & 8 & & & & \\
\hline Total & 453,879 & 12 & & & & 99,6 \\
\hline \multicolumn{7}{|c|}{ DAP - sete meses PAB ${ }^{(3)}$} \\
\hline $\mathrm{N}$ & 58,4705 & 1 & 58,4705 & 1664,45 & $<0,01$ & 98,5 \\
\hline $\mathrm{Ca}$ & 0,548334 & 1 & I,548334 & 15,61 & $<0,01$ & 0,9 \\
\hline Resíduo & 0,35129 & 10 & & & & \\
\hline Total & 59,3701 & 12 & & & & 99,4 \\
\hline \multicolumn{7}{|c|}{ DAP - doze meses PAB ${ }^{(4)}$} \\
\hline $\mathrm{N}$ & 293,671 & 1 & 293,671 & 1417,43 & $<0,01$ & 98,0 \\
\hline $\mathrm{P}$ & 0,47249 & 1 & 0,47249 & 2,28 & 0,17 & 0,2 \\
\hline $\mathrm{Ca}$ & 1,96861 & 1 & 1,96861 & 9,50 & 0,02 & 0,7 \\
\hline $\mathrm{Mg}$ & 1,81581 & 1 & 1,81581 & 8,76 & 0,02 & 0,7 \\
\hline Resíduo & 1,657 & 8 & & & & \\
\hline Total & 299,586 & 12 & & & & 99,5 \\
\hline
\end{tabular}


Tabela 18. Equações de regressão múltipla que relacionam a altura e diâmetro à altura do peito (DAP) das árvores com as concentrações de macronutrientes foliares, aos sete e aos doze meses pósaplicação do biossólido, nos tratamentos em solo degradado

\begin{tabular}{|c|c|c|c|}
\hline Época & Equação & $\mathbf{R}^{2}$ & Signif. \\
\hline & & $\%$ & \\
\hline \multicolumn{4}{|c|}{ Altura } \\
\hline Sete meses & $\mathbf{y}=0,0814994 \mathbf{N}+0,682436 \mathbf{P}-0,198722 \mathbf{C a}$ & 99,9 & $<0,01$ \\
\hline Doze meses & $\mathbf{y}=0,26572 \mathbf{N}-7,82116 \mathbf{P}+0,568594 \mathbf{C a}+3,50269 \mathbf{M g}$ & 99,6 & $<0,01$ \\
\hline \multicolumn{4}{|c|}{ DAP } \\
\hline Sete meses & $\mathbf{y}=0,131664 \mathbf{N}-0,327732 \mathbf{C a}$ & 99,4 & $<0,01$ \\
\hline Doze meses & $\mathbf{y}=0,571368 \mathbf{C a}+3,26546 \mathbf{M g}+0,177982 \mathbf{N}-6,64435 \mathbf{P}$ & 99,5 & $<0,01$ \\
\hline
\end{tabular}




\section{CONCLUSÕES}

Sob condições de solo não-degradado (cultivo mínimo):

1. Nos primeiros sete meses pós-aplicação do biossólido (PAB), houve imobilização de parte do $\mathrm{N}$ do biossólido na serapilheira. Estes resíduos contribuiram para a diminuição das taxas de lixiviação de $\mathrm{N}$ e como uma barreira mecânica ao contato direto do biossólido com o solo. Após este período, as concentrações de $\mathrm{N}$ e de outros nutrientes no solo, oriundos da serapilheira, aumentaram gradativamente;

2. A aplicação de doses crescentes de biossólido aumentou as taxas de mineralização de $\mathrm{N}$ no solo, nos primeiros sete meses $\mathrm{PAB}$. Houve diminuição das concentrações de $\mathrm{N}$ total $(20-30 \mathrm{~cm})$ e de matéria orgânica no solo $(0-20 \mathrm{~cm})$ com o aumento das doses de biossólido, aos doze meses pós-aplicação;

3. $\mathrm{O}$ pH do solo aumentou aos sete meses $\mathrm{PAB}$, somente na camada 0-3 cm;

4. A disponibilidade de $\mathrm{P}(0-20 \mathrm{~cm})$ e $\mathrm{S}(0-30 \mathrm{~cm})$ no solo dos tratamentos que receberam biossólido aumentou a partir dos sete meses PAB; no entanto, as árvores absorveram mais $\mathrm{P}$ apenas aos sete meses $\mathrm{PAB}$, e não houve alterações das concentrações foliares de $\mathrm{S}$;

5. A concentração de $\mathrm{K}$ trocável $(3-10 \mathrm{~cm})$ diminuiu aos sete meses $\mathrm{PAB}$ com o aumento das doses de biossólido. No entanto, esta diminuição refletiu em menor absorção de $\mathrm{K}$ pelas plantas somente aos doze meses $\mathrm{PAB}$;

6. As concentrações de $\mathrm{Ca}$ e $\mathrm{Mg}$ no solo diminuíram com a aplicação de 10,20 tha $^{-1}$ $(0-10 \mathrm{~cm})$ e $40 \mathrm{t} \mathrm{ha}^{-1}(3-10 \mathrm{~cm})$ de biossólido, aos sete meses PAB. Apesar 
disso, as concentrações de $\mathrm{Ca}$ e $\mathrm{Mg}$ no tecido foliar não sofreram alterações nas duas idades avaliadas;

7. As concentrações foliares de $\mathrm{N}$ aumentaram aos três e aos sete meses $\mathrm{PAB}$, em resposta ao aumento da disponibilidade de $\mathrm{N}$ no solo;

8. O biossólido aumentou as taxas de crescimento do E. grandis, conforme avaliação de altura e DAP, apenas aos sete meses PAB. Este aumento foi explicado principalmente pela maior absorção de $\mathrm{N}$ pelas plantas.

\section{Sob condições de solo degradado:}

9. A aplicação do biossólido em superfície inibiu os processos de nitrificação;

10. As quantidades de $\mathrm{N}$ mineralizadas no solo nos tratamentos que receberam biossólido, em seis meses, foram semelhantes às obtidas no Controle do solo não-degradado;

11. Grandes quantidades de $\mathrm{N}$ do biossólido foram perdidas nos primeiros sete meses PAB; estas perdas foram maiores do que as observadas nos tratamentos do solo não-degradado;

12. A aplicação de doses crescentes de biossólido aumentou as concentrações de $\mathrm{C}$ e de $\mathrm{N}$ totais (3-20 cm e 10-20 cm, respectivamente) e de matéria orgânica no solo (0-30 cm), aos doze meses $\mathrm{PAB}$, contrariamente ao observado no solo nãodegradado;

13. As concentrações foliares de $\mathrm{N}$ aumentaram aos três e aos sete meses $\mathrm{PAB}$, em resposta ao aumento da disponibilidade de $\mathrm{N}$ no solo;

14. $\mathrm{O} \mathrm{pH}$ da camada $0-3 \mathrm{~cm}$ do solo aumentou, e o da camada $3-10 \mathrm{~cm}$ diminuiu, aos sete meses PAB;

15. As concentrações de $\mathrm{K}$ no solo e nas folhas não foram modificadas com a aplicação de biossólido, aos sete e aos doze meses PAB;

16. O biossólido aumentou as concentrações de $\mathrm{P}$ e $\mathrm{Ca}$ no solo aos sete $(0-3 \mathrm{~cm})$ e aos doze meses $(0-10 \mathrm{~cm}) \mathrm{PAB}$; este resultado refletiu em aumento nas concentrações foliares de $\mathrm{P}$ aos sete meses, e de $\mathrm{Ca}$ aos doze meses PAB; 
17. O biossólido aumentou as concentrações de $\mathrm{Mg}$ no solo aos sete e aos doze meses PAB $(0-3 \mathrm{~cm})$; este resultado refletiu em aumento nas concentrações foliares de $\mathrm{Mg}$ aos sete meses $\mathrm{PAB}$;

18. O biossólido aumentou as concentrações de $\mathrm{S}-\mathrm{SO} 4^{-2}$ no solo $(0-30 \mathrm{~cm})$ aos sete meses PAB; aos doze meses PAB, estas diminuíram $(0-3 \mathrm{~cm})$ ou foram maiores do que o Controle $(10-30 \mathrm{~cm})$. No entanto, houve aumento das concentrações de $\mathrm{S}$ no tecido foliar apenas aos sete meses PAB;

19. O biossólido aumentou as taxas de crescimento do E. grandis, conforme avaliação de altura e DAP, aos sete, aos doze e aos vinte e dois meses PAB. Este aumento também foi explicado principalmente pela maior absorção de $\mathrm{N}$ pelas plantas.

20. As maiores taxas de crescimento foram observadas no tratamento que recebeu $40 \mathrm{t} \mathrm{ha}^{-1}$ de biossólido, semelhantes às taxas observadas no tratamento com a mesma dose de biossólido em sistema de cultivo mínimo. Nesta dose, portanto, o biossólido compensou a remoção dos $20 \mathrm{~cm}$ superiores do horizonte A. 


\section{REFERÊNCIAS BIBLIOGRÁFICAS}

ABREU JUNIOR, C.H.; MURAOKA, T.; OLIVEIRA, F.C. Carbono, nitrogênio, fósforo e enxofre em solos tratados com composto de lixo urbano. Revista Brasileira de Ciência do Solo, v.26, n.3, p.769-780, 2002.

ADAMS, M.A.; ATTIWILL, P.M. Nutrient cycling and nitrogen mineralization in eucalypt forests of south-eastern Australia II. Indices of nitrogen mineralization. Plant and Soil, v.92, n.3, p.341-362, 1986.

AGBIM, N.N.; SABEY, B.R.; MARKSTROM, D.C. Land application of sewage sludge: V. Carbon dioxide production as influenced by sewage sludge and wood waste mixtures. Journal of Environmental Quality, v.6, n.4, p.446-451, 1977.

ALONSO, R. Reflorestamento contribui para preservação de florestas nativas. http://www.ambiente.sp.gov.br/destaque/reflorestamento1.htm. (07 ago. 2002).

AMARANTE, A. Comportamento geoquímico de metais pesados em sedimentos argilosos da Bacia de São Paulo, Suzano - SP. São Paulo, 1997. 98p. Dissertação (Mestrado) - Instituto de Geociências, Universidade de São Paulo.

ANDRADE, C.A.; MATTIAZZO, M.E. Nitratos e metais pesados no solo e nas árvores após aplicação de biossólido (lodo de esgoto) em plantações florestais de Eucalyptus grandis. Scientia Forestalis, n.58, p.59-72, 2000.

ANDREOLI, C.V. Uso e manejo do lodo de esgoto na agricultura e sua influência em características ambientais no agrossistema. Curitiba, 1999. 282p. Tese (Doutorado) - Universidade Federal do Paraná. 
ANJOS, A.R.M. Lixiviação de espécies químicas em latossolos sucessivamente tratados com biossólido e disponibilidade de metais pesados para plantas de milho. Piracicaba, 1999. 191p. Tese (Doutorado) - Escola Superior de Agricultura “Luiz de Queiroz”, Universidade de São Paulo.

ANJOS, A.R.M.; MATTIAZZO, M.E. Lixiviação de íons inorgânicos em solo repetidamente tratados com biossólido. Revista Brasileira de Ciência do Solo, v.24, n.4. p.927-938, 2000.

ASCHMANN, S.G.; MCINTOSH, M.S.; ANGLE, J.S.; HILL, R.L. Nitrogen movement under a hardwood forest amended with liquid waste-water sludge. Agriculture, Ecosystems \& Environment, v.38, n.4, p.249-263, 1992.

BANCO NACIONAL DE DESENVOLVIMENTO ECONOMICO E SOCIAL. Seminário internacional modelos e políticas de desenvolvimento: tributo a Aníbal Pinto. Rio de Janeiro, 1998. 260p.

BARRETO, M.C.V. Degradação da fração orgânica de diferentes resíduos e efeitos em algumas propriedades químicas e físicas de dois solos. Piracicaba, $1995.106 \mathrm{p}$. Tese (Doutorado) - Escola Superior de Agricultura “Luiz de Queiroz", Universidade de São Paulo.

BARROS, N.F.; NOVAIS, R.F.; NEVES, J.C.L. Níveis críticos de fósforo no solo para eucalipto. Informativo Agropecuário, v.12, n.141, p.15-19, 1986.

BARROS, N.F.; NOVAIS, R.F. Eucalypt nutrition and fertilizer regimes in Brazil. In: ATTIWILL, P.M.; ADAMS, M.A. Nutrition of eucalypt. Collingwood: CSIRO, 1996. cap.15, p. 342-343.

BARROS, N.F.; NOVAIS, R.F.; NEVES, J.C.L. Fertilização e correção do solo para o plantio do eucalipto. In: BARROS, N.F.; NOVAIS, R.F (Ed.). Relação soloeucalipto. Viçosa: Folha de Viçosa, 1990. p.127-186.

BELLOTE, A.F.J.; SARRUGE, J.R.; HAAG, H.P.; OLIVEIRA, G.D. Extração e exportação de nutrientes pelo Eucalyptus grandis Hill ex. Maiden em função da idade: I. Macronutrientes. IPEF, v.20, p.1-23, 1980.

BENBI, D.K.; RICHTER, J. A critical review of some approaches to modelling nitrogen mineralization. Biology and Fertility of Soils, v.35, n.3, p.168-183, 2002. 
BERG, M.P.; KNIESE, J.P.; ZOOMER, R; VERHOEF, H.A. Long-term decomposition of successive organic strata in a nitrogen saturated Scots pine forest soil. Forest Ecology and Management, v.107, n.1/3, p.159-172, 1998.

BERTON, R.S.; CAMARGO, O.A. ; VALADARES, J.M.A.S. Absorção de nutrientes pelo milho em resposta à adição de lodo de esgoto a cinco solos paulistas. Revista Brasileira de Ciência do Solo, v.13, n.2, p.187-192, 1989.

BERTONCINI, E.I.; MATTIAZZO, M.E. Lixiviação de metais pesados em solos tratados com lodo de esgoto. Revista Brasileira de Ciência do Solo, v.23, n.3, p.737-744, 1999.

BEVACQUA, R.F.; MELLANO, V.J. Cumulative effects of sludge compost on crop yields and soil properties. Communications in Soil Science and Plant Analysis, v.25, n.3/4, p.395-406, 1994.

BEZERRA, F.B.; ANDRADE, A.G.; PEREZ, D.V.; OLIVEIRA, M.A.C.L.; MENEGUELI, N.A. Gestão do lodo de esgoto do aeroporto internacional do Rio de Janeiro - Galeão/Antonio Carlos Jobim para adubação de Mimosa caesalpiinifolia e Mimosa bimucronata implantadas em áreas degradadas. In: SIMPÓSIO NACIONAL SOBRE RECUPERAÇÃO DE ÁREAS DEGRADADAS “AGUA E BIODIVERSIDADE”, 5., Belo Horizonte, 2002. Trabalhos voluntários. Belo Horizonte: SOBRADE, 2002. p.490-492.

BOEIRA, R.C.; LIGO, M.A.V.; DYNIA, J.F. Mineralização de nitrogênio em solo tropical tratado com lodos de esgoto. Pesquisa Agropecuária Brasileira, v.37, n.11, p.1639-1647, 2002.

BRAMRYD, T. Impact of sewage sludge application on the long-term nutrient balance in acid soils of Scots pine (Pinus sylvestris, L.) forest. Water Air and Soil Pollution, v.140, p.381-399, 2002.

BRELAND, T.A.; HANSEN, S. Nitrogen mineralization and microbial biomassa a affected by soil compaction. Soil Biology and Biochemistry, v.28, n.4/5, p.65-663, 1996. 
CAMARGO, O.A.; MONIZ, A.C.; JORGE, J.A.; VALADARES, J.M.A.S. Método de análise química, mineralógica e física de solos do Instituto Agronômico de Campinas. Campinas: IAC, 1986. 94p. (IAC. Boletim Técnico, 106).

CANELLAS, L.P.; SANTOS, G.A.; RUMJANEK, V.M.; MORAES, A.A.; GURIDI, F. Distribuição da matéria orgânica e características de ácidos húmicos em solos com adição de resíduos de origem urbana. Pesquisa Agropecuária Brasileira, v.36, n.12, p.1529-1538, 2001.

CANTARELLA, H.; PROCHNOW, L.I. Determinação de sulfato em solos. In: VAN RAIJ, B.; ANDRADE, J.C.; CANTARELLA, H.; QUAGGIO, J.A. Análise química para avaliação da fertilidade de solos tropicais. Campinas: Instituto Agronômico, 2001. p.226-230.

CARDOSO, E. J. B. N; FORTES-NETO, P. Aplicabilidade do biossólido em plantações florestais: III. Alterações microbianas no solo. In: BETTIOL, W.; CAMARGO, O.A. Impacto ambiental do uso agrícola do lodo de esgoto. Jaguariúna: EMBRAPA Meio Ambiente, 2000. cap.10, p.197-202.

CARMO, J.B. Impacto da aplicação de biossólido nas atividades microbianas do solo. Piracicaba, 2001. 105p. Dissertação (Mestrado) - Escola Superior de Agricultura “Luiz de Queiroz”, Universidade de São Paulo.

CARVALHO, P.C.T; CARVALHO, F.J.P. Legislação sobre biossólido. In: TSUTIYA, M.T.; COMPARINI, J.B.; SOBRINHO, P.A.; HESPANHOL, I.; CARVALHO, P.C.T; MELFI, A.J.; MELO, W.J.; MARQUES, M.O. Biossólidos na agricultura. São Paulo: SABESP: 2001. cap.7, p.209-226.

CASTRO, L.A.R.; ANDREOLI, C.V.; PEGORINI, E.S.; TAMANINI, C.R.; FERREIRA, A.C. Efeito do lodo de esgoto como recuperador de áreas degradadas com finalidade agrícola. In: SIMPÓSIO NACIONAL SOBRE RECUPERAÇÃO DE ÁREAS DEGRADADAS “AGUA E BIODIVERSIDADE”, 5., Belo Horizonte, 2002. Trabalhos voluntários. Belo Horizonte: SOBRADE, 2002. p.234-239.

CAVALLARO N, PADILLA N, VILLARRUBIA, J. Sewage-sludge effects on chemical-properties of acid soils. Soil Science, v.156, n.2, p.63-70, 1993. 
CELA, S.; SUMNER, M.E. Soil zinc fractions determine inhibition of nitrification. Water Air and Soil Pollution, v.141, n.1-4, p.91-104, 2002.

CENTRO NACIONAL DE REFERÊNCIA E GESTÃO AMBIENTAL E URBANA. Utilização agrícola do lodo de esgoto como fertilizante. http://www.bis.com.br/unilivre/centro/experiência/015.html. (28 ago. 2002).

COMPANHIA DE TECNOLOGIA E SANEAMENTO AMBIENTAL. Aplicação de biossólido de sistema de tratamento biológico em áreas agrícolas - critérios para projeto e operação. São Paulo. 1999. 35p. (Manual Técnico).

CONFERÊNCIA DAS NAÇÕES UNIDAS SOBRE MEIO AMBIENTE E DESENVOLVIMENTO SUSTENTÁVEL. Agenda 21: Conferência das Nações Unidas sobre Meio Ambiente e Desenvolvimento. Brasília: Senado Federal, 1997. 598p.

CORNU, S., NEAL, C.; AMBROSI, J.P.; WHITEHEAD, P.; NEAL, M.; SIGOLO, J.; VACHIER, P. The environmental impact of heavy metals from sewage sludge in ferralsols (Sao Paulo, Brazil). Science of the Total Environment, v.271, n.1/3, p.27-48, 2001.

CROHN, D.M.; HAITH, D.A. A forest site nitrogen dynamics model for land application of sludge. Transactions of the Asae, v.37, p.1135-1144, 1994./'Resumo em ISI Web of http://isi10.isiknowledge.com/portal.cgi?DestApp=WOS\&Func=Frame. $\quad(24$ jan. 2003).

CROHN, D.M.; HAITH, D.A. Sustainability of sewage sludge land application to northern hardwood forests. Ecological Applications, v.5, p.53-62, 1995./'Resumo em ISI Web of Science/ http://isi10.isiknowledge.com/portal.cgi?DestApp=WOS\&Func=Frame. $\quad(24$ jan. 2003).

CURI, N.; LARACH, J.O.I.; KÄMPF, N.; MONIZ, A.C.; FONTES, L.E.F. Vocabulário de ciência do solo. Campinas: Sociedade Brasileira de Ciência do Solo, 1993. 90p. 
DA ROS, C.O.; AITA.C.; CERETTA, C.A.; FRIES, M.R. Lodo de esgoto: efeito imediato no milheto e residual na associação aveia-ervilhaca. Revista Brasileira de Ciência do Solo, v.17, n.2, p.257-261, 1993.

DANIELS, W.L.; HAERING, K.C. Use of sewage sludge for land reclamation in the Central Appalachians. In: CLAPP, C.E.; LARSON, W.E.; DOWDY, R.H. Sewage sludge: land utilization and the environment. Madison: American Society of Agronomy; Crop Science Society of America; Soil Science Society of America, 1994. cap.16, p.105-121.

DE NEVE, S.; HOFMAN, G. Influence of soil compaction on carbon and nitrogen mineralization of soil organic matter and crop residues. Biology and Fertility of Soils, v.30, p.544-549, 2000.

DIAS, L.E.; GRIFFITH, L.E. Conceituação e caracterização de áreas degradadas. In: DIAS, L.E.; MELLO, J.W. (Ed.). Recuperação de áreas degradadas. Viçosa: UFV: Departamento de Solos; Sociedade Brasileira de Recuperação de Áreas Degradadas, 1988. p. 1-8.

DUTCH, J., WOLSTENHOLME, R., BENGTSSON, J., LUNDKVIST, H. The effects of the sludge application to a hesthland site prior to planting with Sitka spruce. Forest Ecology and Management, v.66, n. 1/3, p. 151-163, 1994.

EICK, M.J.; BRADY, W.D.; LYNCH, C.K. Charge properties and nitrate adsorption of some acid Southeastern soils. Journal of Environmental Quality, v.28, n.1, p.138144, 1999.

EMPRESA BRASILEIRA DE PESQUISA AGROPECUÁRIA Sistema brasileiro de classificação de solos. Rio de Janeiro, 1999. 412 p.

EMPRESA BRASILEIRA DE PESQUISA AGROPECUÁRIA. Manual de métodos de análise de solo. Rio de Janeiro: EMBRAPA: CNPS, 1997. 212p. (Documentos, 1).

ENTRY, J.A.; FARMER, N. Movement of coliform bacteria and nutrients in ground water flowing through basalt and sand aquifers. Journal of Environmental Quality, v.30, n.5, p.1533-1539, 2001. 
ESTADOS UNIDOS ENVIRONMENTAL PROTECTION AGENCY. Process design manual: land application of sewage sludge and domestic septage. Washington, 1995. 290p.

ESTADOS UNIDOS. Environmental Protection Agency. Standards for the use and disposal of sewage sludge. Washington, 1997. 25p. (Code of Federal Regulations 40 CFR Part 503).

FARIA, L.C. Fertilização de povoamentos de eucalipto com o biossólido da ETE de Barueri, SP: demanda potencial e nível mínimo de resposta. Piracicaba, 2000. 85p. Dissertação (Mestrado) - Escola Superior de Agricultura “Luiz de Queiroz”, Universidade de São Paulo.

FARIA, L.C.; PASQUINI, C. Flow-injection determination of inorganic forms of nitrogen by gas-diffusion and conductimetry. Analytica Chimica Acta, v. 245, n.2, p. 183-190, 1991.

FORTES NETO, P. Degradação de biossólido incorporado ao solo avaliada através de medidas microbiológicas. Piracicaba, 2000. 113p. Tese (Doutorado) - Escola Superior de Agricultura “Luiz de Queiroz”, Universidade de São Paulo.

FURTINI NETO, A.E.; BARROS, N.F.; NOVAIS, R.F.; OLIVEIRA, M.F.G. Frações fosfatadas em mudas de Eucalyptus. Revista Brasileira de Ciência do Solo, v.22, p.267-274, 1998.

FURTINI NETO, A.E.; VALE, F.R.; MUNIZ, J.A.; GUILHERME, L.R. Efeito do enxofre na assimilação de nitrogênio por cinco espécies de eucalipto. Ciência e Prática, v.14, n.2. p.158-170, 1990.

GERKE, H.H.; ARNING, M.; STÖPPLER-ZIMMER, H. Modeling long-term compost application effects on nitrate leaching. Plant and Soil, v.213, n.1-2, p.75-92, 1999.

GINE, MF.; BERGAMIN, H.; ZAGATTO, E.A.G.; REIS, B.F. Simultaneous determination of nitrate and nitrite by flow-injection analysis. Analytica Chimica Acta, v.114, p.191-197, 1980.

GONÇALVES, J.L.M.; BARROS, N.F. Improvement of site productivity for shortrotation plantations in Brazil. Bosque, v.20, n.1, p.89-106, 1999. 
GONÇALVES, J.L.M.; RAIJ, B. van; GONÇALVES, J.C. Florestais. In: RAIJ, B. van; CANTARELlA, H.; QUAGGIO, J.A.; FURLANI, A.M.C. Recomendações de adubação e calagem para o Estado de São Paulo. Campinas: Instituto Agronômico \& Fundação IAC, 1996. cap.23, p 247-259.

GONCALVES, J.L.M.; MENDES, K.C.F.S.; SASAKI, C.M. Mineralização de nitrogênio em ecossistemas florestais naturais e implantados do estado de São Paulo. Revista Brasileira de Ciência do Solo, v.25, n.3. p.601-616, 2001.

GONCALVES, J.L.M.; SERRANO, M.I.P.; MENDES, K.C.F.S.; GAVA, J.L. Effects of site management in Eucalyptus grandis plantation in the humid tropics: São Paulo, Brazil. In: NAMBIAR, E.K.S.; TIARKS, A.; COSSALTER, C.; RAGER, J. (Ed.). Site management and productivity in tropical plantation forests, 1999. Proceedings. Bogor: Center of International Forestry Research, 2000a. p.3-9.

GONCALVES, J.L.M.; VAZ, L.M.S.; AMARAL, T.M.; POGGIANI, F. Aplicabilidade de biossólidos em plantações florestais - Efeito na fertilidade do solo, nutrição e crescimento das arvores. In: BETTIOL, W.; CAMARGO, O.A. Impacto ambiental do uso agrícola do lodo de esgoto. Jaguariúna: EMBRAPA, 2000b, cap. 9, p.179-195.

GONCALVES, J.L.M.; STAPE, J.L.; WITCHERT, M.C.P.; GAVA, J.L. Manejo de resíduos vegetais e preparo de solo. In: GONCALVES, J.L.M.; STAPE, J.L. Conservação e cultivo de solos para plantações florestais. Piracicaba: IPEF, 2002. cap.3, p.131-204.

GUEDES, M. C. Efeito do lodo de esgoto (biossólido) sobre a nutrição, ciclagem de nutrientes e crescimento de sub-bosque, em plantação de eucalipto. Piracicaba, 2000. 74p. Dissertação (Mestrado) - Escola Superior de Agricultura "Luiz de Queiroz”, Universidade de São Paulo.

HARRISON, R.B.; GESSEL, S.P.; ZABOWAKI, D.; HENRY, C.L.; XUE, D.S.; COLE, D.W.; COMPTON, J.E. Mechanisms of negative impacts of three forest treatments on nutrient availability. Soil Science Society of America Journal, v.60, n.6, p.1622-1628, 1996. 
HARRISON, R.; XUE, D.; HENRY, C.; COLE, D.W. Long-term effects of heavy applications of biosolids on organic matter and nutrient content of a coarse-textured forest soil. Forest Ecology and management, v.66, p.165-167, 1994.

HENRY, C.L.; COLE, D.W.; HARRISON, R.B. Use of municipal sludge to restore and improve site productivity in forestry: the Pack Forest Sludge Research Program. Forest Ecology and management, v.66, n.1-3, p.137-149, 1994.

HESPANHOL, I. Biossólidos, meio ambiente e saúde publica critérios para o estabelecimento de diretrizes. In: TSUTIYA, M.T.; COMPARINI, J.B.; SOBRINHO, P.A.; HESPANHOL, I.; CARVALHO, P.C.T; MELFI, A.J.; MELO, W.J.; MARQUES, M.O. Biossólidos na agricultura. São Paulo: SABESP: 2001, cap.10, p.273-287.

HUE, N.V.; LICUDINE, D.L. Amelioration of subsoil acidity through surface application of organic manures. Journal of Environmental Quality, v.28, n.2, p.623-632, 1999.

ILLERA, V; WALTER I; CUEVAS G; CALA V. Biosolid and municipal solid waste effects on phisical and chemical properties of a degraded soil. Agrochimica, v.43, n.3/4, p.178-186, 1999.

INSAM, H.; MERSCHAK, P. Nitrogen leaching from forest soil cores after amending organic recycling products and fertilizers. Waste Management and Research, v.15, n.3, p. 277-291, 1997.

INSTITUTO BRASILEIRO DE GEOGRAFIA E ESTATÍSTICA. Indicadores de desenvolvimento sustentável: Brasil 2000/IBGE. Rio de Janeiro: IBGE, 2002. 195p. (Estudos e pesquisas. Informações geográficas,.2)

INSTITUTO BRASILEIRO DO MEIO AMBIENTE E DOS RECURSOS NATURAIS RENOVAVEIS. Manual de recuperação de áreas degradadas pela mineração: técnicas de revegetação. Brasília, 1990. 96p.

INSTITUTO DE PESQUISAS TECNOLÓGICAS DO ESTADO DE SÃO PAULO. Mapa geológico do Estado de São Paulo. São Paulo, 1981. v.1, Escala: 1: 500.000 . 
JAMES, B.R.; ASCHMANN, S.G. Soluble phosphorus in a forest soil Ap horizon amended with municipal wasterwater sludge or compost. Communications in Soil Science and Plant Analysis, v.23, n.7/8, p.861-875, 1992.

JONES JUNIOR, J. B.; MILLS, H.A. Plant analysis handbook II. Athens : MicroMacro Publ., 1991. cap.2, p.7-53: Essential plant nutrients.

JORGE, J.A.; CAMARGO, O.A.; VALADARES, J.M.A.S. Condições físicas de um latossolo vermelho-escuro quatro anos após aplicação de lodo de esgoto e calcário. Revista Brasileira de Ciência do Solo, v. 15, n.3, p. 237-240, 1991.

KOLM, L. Ciclagem de nutrientes e variações do microclima em plantações de Eucalyptus grandis Hill ex. Maiden manejadas através de desbastes progressivos. Piracicaba, 2001. 88p. Tese (Mestrado) - Escola Superior de Agricultura “Luiz de Queiroz”, Universidade de São Paulo.

KUZYAKOV, Y.; FRIEDEL, J.K.; STAHR, K. Review of mechanisms and quantification of priming effects. Soil Biology and Biochemistry, v.32, p.14851489, 2000.

LADD, J.N.; FOSTER, R.C.; SKJEMSTAD, J.O. Soil structure: carbon and nitrogen metabolism. Geoderma, v.56, p. 401-434, 1993.

LAMBAIS, M.R.; De SOUZA, A.G. Impacto de biossólidos nas comunidades microbianas dos solos. In: In: BETTIOL,W.; CAMARGO,O.A. Impacto ambiental do uso agrícola do lodo de esgoto. Jaguariúna: EMBRAPA Meio Ambiente, 2000. cap.17, p.269-279.

LEITE, N.B. Reflorestamento industrial no Brasil: uma atividade sustentável. http:/www.sbs.org.br/palestra_consulado_japao.ppt (05 mar. 2003)

LEMOS, R.C.; SANTOS, R.D. Manual de descrição e coleta do solo no campo. Campinas: Sociedade Brasileira de Ciência do Solo e Serviço Nacional de Levantamento e Conservação de Solo, 1982. 45p.

LERCH, R.N.; BARBARICK, K.A.; SOMMERS L.E.; WESTFALL, D.G. Sewage sludge proteins as labile carbon and nitrogen sources. Soil Science Society of America Journal, v.56, n.5, p.1470-1476, 1992. 
LINDERMAN, W.C; CARDENAS, M. Nitrogen mineralization potential and nitrogen transformations of sludge-amended soil. Soil Science Society of American, v.48, n.5, p. 1072-1077, 1984.

LOCATELLI, M.; BARROS, N.F.; NEVES, J.C.L.; NOVAIS, R.F. Efeito de formas de nitrogênio sobre o crescimento e composição mineral de mudas de eucalipto. Revista Árvore, v.8, p.53-69, 1984.

LOGAN, T.J.; HARRISON, B.J.; PREZOTTO, M.E.M.; LUCCHESI, L.A.C. Recuperação de áreas ácidas mineradas de carvão através da utilização de lodo de esgoto com avançada estabilização alcalina, N-Viro soil. In: SIMPOSIO SULAMERICANO, 1.; SIMPOSIO NACIONAL DE RECUPERACAO DE AREAS DEGRADADAS, Foz do Iguaçu, 1994. Anais. Curitiba: FUPEF, 1994. p.313-27. LOGAN, T.J.; LINDSAY, B.J.; GOINS, L.E.; RYAN, J.A. Field assessment of sludge metal bioavailability to crops: sludge rate response. Journal of Environmental Quality, v.26, n.2, p.534-550, 1997.

LOPES, E.B.M. Diversidade metabólica em solos tratados com biossólidos. Piracicaba, 2001. 65p. Dissertação (Mestrado) - Escola Superior de Agricultura “Luiz de Queiroz”, Universidade de São Paulo.

LOUW, J.H. A site - growth study of Eucalyptus grandis in the Mpumalanga Escarpment area. Southern African Forestry Journal, v.180, p.1-14, 1997.

LOW, A.P.; STARK, J.M.; DUDLEY, L.M.; Effects of soil osmotic potential on nitrification, ammonification, $\mathrm{N}$-assimilation, and nitrous oxide production. Soil Science, v.162, p.1, p.16-27, 1997.

LU, P.; O'CONNOR, G.A. Biosolids effects on phosphorus retention and release in some sandy Florida soils. Journal of Environmental Quality, v.30, n.3, p.10591063, 2001.

LUDOVICE, M. Gestão de biossólido e o Mercosul. In: SEMINÁRIO SOBRE GERENCIAMENTO DE BIOSSÓLIDOS NO MERCOSUL, Curitiba, 1998. Anais. Curitiba: ABES, 1998. p.9-10. 
LUXMOORE, R.J.; THARP, M.L.; EFROYMSON, R.A. Comparison of stimulated forest responses to biosolids applications. Journal of Environmental Quality, v.28, n.6, p.1996-2007, 1999.

MACEDO, J.R. Selamento superficial e atributos físicos e hídricos em solo tratado com lodo de esgoto. Piracicaba, 2002. 87 p. Dissertação (Doutorado) - Escola Superior de Agricultura “Luiz de Queiroz”, Universidade de São Paulo.

MADEIRA, M.; ARAÚJO, M.C.; PEREIRA, J.S.; HUTTL, R.F.; NILSSON, L.O.; JOHANSSON, U.T. Effects of water and nutrients supply on amout and on nutrient concentration of litterfall and forest floor litter in Eucalyptus globulus plantations. Plant and Soil, v.169, p.287-295, 1995.

MAGUIRE, R.O.; SIMS, J.T.; COALE, F.J. Phosphorus solubility in biosolids-amended farm soils in the Mid-Atlantic Region of the USA. Journal of Environmental Quality, v.29, n.4, p.1225-1233, 2000.

MALAVOLTA, E. Elementos de nutrição mineral de plantas. São Paulo: Agronômica Ceres, 1980. 251p.

MALAVOLTA, E.; VITTI, E.C.; OLIVEIRA, S.A. Avaliação do estado nutricional das plantas (princípios e aplicações). 2. ed. Piracicaba: Associação Brasileira do Potássio e do Fósforo, 1997. 319 p.

MAMO, M.; ROSEN, C.J.; HALBACH, T.R. Nitrogen availability and leaching from soil amended with municipal solid waste compost. Journal of Environmental Quality, v.28, n.4, p.1074-1082, 1999.

MARCIANO, C.R. Incorporação de resíduos urbanos e as propriedades físico-hídricas de um Latossolo Vermelho Amarelo. Piracicaba, 1999. 93p. Tese (Doutorado) Escola Superior de Agricultura “Luiz de Queiroz”, Universidade de São Paulo.

MARSCHNER, H. Mineral nutrition of higher plants. London: Academic Press, 1986. cap.2, p.7-69: Soil-plant relationships.

MENGEL, K.; KIRKBY, E.A. Principles of plant nutrition. Bern:International Potash Institute, 1987. cap.3, p.113-173: Nutriente uptake and assimilation. 
MARTINS, L.F.S. Configuração do sistema radicular das árvores de Eucalyptus grandis em resposta à aplicação de doses crescentes de biossólido. Piracicaba, 2002. 73p. Dissertação (Mestrado) - Escola Superior de Agricultura “Luiz de Queiroz”, Universidade de São Paulo.

MATTIAZZO, M.E.; BARRETO, M.C.V.; RODELLA, A.A. Organic matter kinetics mineralization in soil amended with four different organic waste. In: WORLD CONGRESS OF SOIL SCIENCE, 16., Montpellier, 1998. (compact disc). Proceedings. Montpellier: s.ed., 1998. CD-ROM.

MC DOWELL, R.W; SHARPLEY, A.N. Phosphorus losses in subsurface flow before and after manure application to intensively farmed land. The Science of the Total Environment, v. 278, n.1/3, p.113-125, 2001.

MEDALIE L.; BOWDEN, W.B.; SMITH C.T. Nutrient leaching following land application of aerobically digested municipal sewage-sludge in a northen hardwood forest. Journal of Environmental Quality, v.23, n.1, p.130-138, Jan-Feb.1994.

MELO, W.J.; MARQUES, M.O. Potencial do lodo de esgoto como fonte de nutrientes para as plantas. In: BETTIOL, W.; CAMARGO, O.A. Impacto ambiental do uso agrícola do lodo de esgoto. Jaguariúna: EMBRAPA Meio Ambiente, 2000. cap.5, p.109-41.

MELO, W.J.; MARQUES, M.O.; SANTIAGO, G.; CHELLI, R.A.; LEITE, S.A.S. Efeito de doses crescentes de lodo de esgoto sobre frações da matéria orgânica e CTC de um latossolo cultivado com cana-de-açúcar. Revista brasileira de Ciência do Solo, v.18, n.3, p.449-455, 1994.

METZGER, L.; ROBERT, M. A scanning electron microscopy study of the interactions between sludge organic components and clay particles. Geoderma, v.35, n.2, p.159167, 1985.

METZGER, L.; LEVANON, D.; MINGELGRIN, U. The effect of sewage sludge on soil structural stabilitu: microbiological aspects. Soil Science Society of America Journal, v.51, n.2, p.346-351, 1987. 
MEYER, V.F.; REDENTE, E.F.; BARBARICK, K.A.; BROBST, R. Biosolid applications after runoff water quality following forest fire. Journal of Soil Environmental Quality, v.30, n.5, p.1528-1532, 2001.

MITCHELL, D.S.; EDWARDS, A.C.; FERRIER, R.C. Changes in fluxes of N and P in water draining a stand of Scots pine treated with sewage sludge. Forest Ecology and management, v.139, n.1/3, p.203-213, 2000.

MOREIRA, A.; MALAVOLTA, E.; GONÇALVES, J.L.M.; LUCCA, E.F. Influência da cobertura vegetal na capacidade de adsorção de fósforo em um latossolo vermelho escuro distrófico. Revista de Ciências Agrárias, v. n.35, p.63-71, 2001.

MORONI, M.T.; SMERTHURST, P.J.; HOLZ, G.K. Nitrogen fluxes in surface soils of young Eucalyptus nitens plantations in Tasmania. Australian Journal of Soil Research, v.40, n.3, p.543-553, 2002.

NACIONAL RESEARCH COUNCIL. Comitee on Nitrate Accumulation. Accumulation of nitrate. Washington: National Academy of Science, 1972. 106p.

NAVAS, A., MACHIN, J., NAVAS, B. Use of biosolids to restore the natural vegetation cover on degraded soil in the badlands of zaragoza (NE Spain). Bioresource Technology, v.69, n.3, p.199-205, 1999.

NELSON, D.W.; SOMMERS, L.E. Total carbon, organic carbon and organic matter. In: PAGE, A.L.; MILLER, R.H.; KEENEY, D.R. (Ed.). Methods of soil analys: pt.2: chemical and microbiological properties. 2.ed. Madison: ASA, 1982. p.539579. (Agronomy, 9).

NIELSEN, N.E, HANSEN, E.M. Macro nutrient cation uptake by plants 2. Effects of plant-species, nitrogen concentration in the plant, cation concentration, activity and activity ratio in soil solution. Plant and Soil, v.77, n.2/3, p.347-365, 1984.

NOVAIS, R.F.; SMYTH, T.J. Fósforo e ambiente. In: Fósforo em solo e planta em condições tropicais. Viçosa: UFV, Departamento de Solos, 1999. p.290-302.

NOVAIS, R.F.; BARROS, N.F.; NEVES, J.C.L. Interpretação de análise química do solo para o crescimento e desenvolvimento de Eucalyptus spp. - Níveis críticos de implantação e manutenção. Revista Árvore, v.10, n.1, p.105-111, 1986. 
NOVAIS, R.F.; BARROS, N.F.; NEVES, J.C.L. Nutrição mineral do Eucalipto. In: BARROS, N.F.; NOVAIS, R.F. Relação solo-eucalipto. Viçosa: Ed. Folha de Viçosa, 1990. cap.2, p.25-98.

OHIO ENVIRONMENTAL PROTECTION AGENCY. Division of Surface Water. General information. http://chagrin.epa.ohio.gov/programs/sludge/1html, (03 mai. 2000).

OLIVEIRA, F.C. Disposição de lodo de esgoto e composto de lixo urbano num Latossolo Vermelho Amarelo cultivado com cana-de-açúcar. Piracicaba, 2000. 247p. Tese (Doutorado) - Escola Superior de Agricultura “Luiz de Queiroz”, Universidade de São Paulo.

OLIVEIRA, F.C.; MATTIAZZO, M.M. Lixiviação de nitrogênio em solos tratados com lodo de esgoto (compact disc). In: CONGRESSO LATINO-AMERICANO DE CIÊNCIA DO SOLO, 13., Águas de Lindóia, 1996. Solo-suelo 96: trabalhos. Piracicaba: SBCS; SLCS, 1996.

OLIVEIRA, F.C.; MARQUES, M.O.; BELLINGIERI, P.A.; PERECIN, D. Lodo de esgoto como fonte de macronutrientes para a cultura do sorgo granífero. Scientia Agricola, v.52, n.2, p.360-367, 1995.

OLIVEIRA, F.C.; MATTIAZZO, M.M.; MARCIANO, C.R.; MORAES, S.O. Lixiviação de nitrato em um Latossolo Amarelo Distrófico tratado com lodo de esgoto e cultivado com cana-de-açúcar. Scientia Agricola, v.58, n.1. p.171-180, 2001.

OLIVEIRA, F.C.; MATTIAZZO, M.E.; MARCIANO, C.R.; ROSSETTO, R. Efeito de aplicações sucessivas de lodo de esgoto em um Latossolo Amarelo Distrófico cultivado com cana-de-açúcar: carbono orgânico, condutividade elétrica, pH e CTC. Revista Brasileira de Ciência do Solo, v.26, n.2. p.505-520, 2002.

PAUL, K.; CONYERS, M. Development of nitrogen mineralization gradients through surface soil depth and their influence on surface soil pH. Plant and Soil, v.243, p.239-246, 2001. 
PHILLIPS, R.; FISHER, J.T.; MEXAL, J.G. Fuelwood production utilizing Pinus eldarica and sewage sludge fertilizer. Forest Ecology and Management, v.16, n.1/4, p.95-102, 1986.

PIERCE, B.L.; REDENTE, E.F.; BARBARICK, K.A.; BROBST, R.B.; HEGEMAN, P. Plant biomass and elemental changes in shrubland forages following biosolids application. Journal of Environmental Quality, v.27, n.4, p.789-794, 1998.

PIETZ, R.I.; CARLSON, JUNIOR.; PETERSON, J.R.; ZENS, D.R.; LUE-HING, C. Applications of sewage sludge and other amendments to coal refuse material: II Effects on revegetation. Journal of Environmental Quality, v.18, n.2, p.169-173, 1989a.

PIETZ, R.I.; CARLSON, JUNIOR.; PETERSON, J.R.; ZENS, D.R.; LUE-HING, C. Applications of sewage sludge and other amendments to coal refuse material: III Effects on percolate waters composition. Journal of Environmental Quality, v.18, n.2, p.174-179, 1989b.

POGGIANI, F.; SCHUMACHER, M.V. Atmospheric inputs compared with nutrient removed by harvesting from Eucalyptus plantation: implications for sustainability. In: IUFRO CONFERENCE ON SILVICULTURE AND IMPROVEMENT OF EUCALYPTS, Salvador, 1997. Anais. Colombo: EMBRAPA/CNPF, 1997. v.4, p.68-74.

POGGIANI, F.; GUEDES, M.C.; BENEDETTI, V. Aplicabilidade de biossólido em plantações florestais I. Reflexo no ciclo dos nutrientes. In: BETTIOL, W.; CAMARGO, O.A. (Ed.). Impacto ambiental do uso agrícola do lodo de esgoto. Jaguariúna: EMBRAPA Meio Ambiente, 2000. cap.8, p. 163-178.

PRESCOTT, C.E.; MCDONALD, M.A.; GESSEL, S.P.; KIMMINS, J.P. Long-term effects of sewage sludge and inorganic fertilizer on nutrient turnover in litter in a coastal Douglas fir forest. Forest ecology and Management, v.59, p.149-164, 1993.

PROGRAMA NACIONAL DE FLORESTAS. Política nacional de florestas. http://www.mma.gov.br/port/sbf/pnf/politica.html. (17 mar. 2003). 
RAIJ, B. van; QUAGGIO, J.A. Métodos de análise de solo para fins de fertilidade. Campinas: Instituto Agronômico, 1983. (IAC. Boletim Técnico, 81).

RAIJ, B. van; CANTARELLA, H.; QUAGGIO, J.A.; FURLANI, A.M.C. Recomendações de adubação e calagem para o Estado de São Paulo. 2 ed. Campinas: IAC, 1996. 285p. (IAC. Boletim Técnico, 100)

RAISON, R.J.; CONNEL, M.J.; KHANNA,P.K. Methodology for studyng fluxes of soil mineral-N in situ. Soil Biology and Biochemistry, v.19, n.5, p.521-530, 1987.

REIS, M.G.F.; BARROS, N.F.; KIMMINS, J.P. Acumulo de nutrientes em uma seqüência de idade de Eucalyptus grandis W. Hill (ex Maiden) plantado no cerrado, em duas áreas com diferentes produtividades, em Minas Gerais. Revista Árvore, v.11, n.1, p.1-15, 1987.

REIS, T.C.; RODELLA, A.A. Cinética de degradação da matéria orgânica e variação do pH do solo sob diferentes temperaturas. Revista Brasileira de Ciência do Solo, v.26, n.3, p.619-626, jul./set.2002.

REUTER, R. Sewage sludge as na organic amendment for reclaiming surface mine wastes. http://www.hort.agri.umn.edu/h5015/97papers/reuter.html. (08 maio 2000).

ROBINSON, M.B.; POLGLASE, P.J.; WESTON, C.J. Loss of mass and nitrogen from biosolids applied to a pine plantation. Australian Journal of Soil Research, v.40, n.6, p.1027-1039, 2002.

ROCHA, G.N. Monitoramento da fertilidade do solo, nutrição mineral e crescimento de um povoamento de Eucalyptus grandis fertilizado com biossólido. Piracicaba, 2002. 48p. Dissertação (Mestrado) - Escola Superior de Agricultura "Luiz de Queiroz", Universidade de São Paulo.

ROCHA, M.T. Utilização do lodo de esgoto na agricultura: um estudo de caso para as bacias hidrográficas dos rios Piracicaba, Capivari e Jundiaí. Piracicaba, 1998. 140p. Dissertação (Mestrado) - Escola Superior de Agricultura “Luiz de Queiroz”, Universidade de São Paulo.

RUZICKA, J.; HANSEN, E.H. Flow injection analysis. Part I. The concept of a new, simple, ultrafast continuous flow analyser. Analitica Chimica Acta, v.78, n.1, p.145-157, 1975. 
RYAN, J.A.; KEENEY, D.R.; WALSH, L.M. Nitrogen transformations and availability of an anaerobically digested sewage sludge in soil. Journal of Environmental Quality, v.2, n.4, p.489-492, 1973.

RYDIN, E.; OTABBONG, E. Potential release of phosphorus from soil mixed with sewage sludge. Journal of Environmental Quality, v.26, n.2, p.529-534, 1997.

SANTOS, H.F. Aplicação do lodo de Estações de Tratamento de Esgoto em solos agrícolas. Revista DAE, v.39, n.122, p. 31-48, 1979.

SCHOENHOLTZ, S.H.; VAN MIEGROET, H.; BURGER, J.A. A review of chemical and physical properties as indicators of forest soil quality: challenges and opportunities. Forest Ecology and Management, v.138, n.1/3, p.335-356, 2000.

SHEARER, A.; SHEARER, B. Land applied sludges: solution or problem? Groundwater Pollution Prier. http://ce.edu/enviro2/gwprimer/group09/intro.htm, (08 maio 2000).

SHEPHERD, M.A.; WITHERS, P.J. Phosphorus leaching from liquid digested sewage sludge applied to sandy soils. Journal of Agricultural Science, v.136, p.433-441, 2001.

SIERRA, J.; DESFONTAINES, L; FONTAINE, S. Factors controlling N mineralization, nitrification, and nitrogen losses in an Oxisol amended with sewage sludge. Australian Journal of Soil Research, v.39, n.3, p.519-534, 2001.

SIGOLO, J.B. Aplicação da geoquímica de superfície na análise da mobilidade e concentração de metais pesados em ambiente tropical. São Paulo, 1998. 216p. Tese (Livre Docência) - Instituto de Geociências, Universidade de São Paulo.

SILVA, F.C. Uso do lodo de esgoto: efeitos em fertilidade do solo e qualidade da canade-açúcar. Piracicaba, 1995. 159p. Tese (Doutorado) - Escola Superior de Agricultura "Luiz de Queiroz", Universidade de São Paulo.

SILVA, F.C.; BOARETO, A.E.; BERTON, R.S.; ZOTELI, H.B.; PEXE, C.A.; MENDONÇA, E. Cana-de-açúcar cultivada em solo adubado com lodo de esgoto: nutrientes, metais pesados e produtividade. Pesquisa Agropecuária Brasileira, v.13, n.1, p.1-8, 1998. 
SILVA, F.C.; BOARETTO, A.E.; BERTON, R.S.; ZOTELLI, H.B.; PEXE, C.A.; BERNARDES, E.M. Efeito de lodo de esgoto na fertilidade de um Argissolo Vermelho-Amarelo cultivado com cana-de-açúcar. Pesquisa Agropecuária Brasileira, v.36, n.5, p.831-840, 2001.

SILVA, J.E.; RESCK, D.V.S.; SHARMA, R.D.; FEITOZA, L. Utilização do lodo de esgoto como fonte de fósforo e nitrogênio para milho (compact disc). In: CONGRESSO LATINO-AMERICANO DE CIÊNCIA DO SOLO, 13., Águas de Lindóia, 1996. Solo-suelo 96: trabalhos. Piracicaba: SBCS; SLCS, 1996.

SIMEONI, L.A.; BARBARICK, K.A.; SABEY, B.R. Effect of small-scale composting of sewage sludge on heavy metal availability to plants. Journal of Environmental Quality, v.13, n.2, p.264-268, 1984.

SIMONETE, M.A. Alterações nas propriedades químicas de um Argissolo adubado com lodo de esgoto e desenvolvimento e acúmulo de nutrientes em plantas de milho. Piracicaba, 2001. 89p. Dissertação (Mestrado) - Escola Superior de Agricultura "Luiz de Queiroz", Universidade de São Paulo.

SKOUSEN J.; KLINGER, C. Sewage sludge land application program in West Virginia. Journal of Soil and Water Conservation, v.48, n.2, p. 145-151, 1998.

SOIL SCIENCE SOCIETY OF AMERICA Glossary of soil science terms. Madison, 1997. $134 \mathrm{p}$.

SOMMERS, L.E.; NELSON, D.W.; YOST, K.J. Variable nature of chemical composition of sewage sludge. Journal of Environmental Quality, v.5, p.303306, 1976.

SOPPER W. Rapid ecological restoration of mine land using municipal sludge. In: LAND RECLAMATION: ADVANCES IN RESEARCH \& TECHNOLOGY INTERNATIONAL SYMPOSIUM, Nashville, 1992. Proceedings. St. Joseph: ASAE, 1992. p.317-326.

SORT, X.; ALCAÑIZ, J.M. Modification of soil porosity after application of sewage sludge. Soil \& Tillage Research, v.49, n.4, p.337-345, 1999. 
SUI, Y.; THOMPSON, M.L.; MIZE, C.W. Redistribution of biosolids-derived total phosphorus applied to a mollisol. Journal of Environmental Quality, v.28, n.4, p.1068-1074, 1999.

SUPRAYOGO, D.; VAN NOORDWIJIK, M.; HAIRIAH, K.; CADISCH, G. The inherent 'safety-net' of an Acrisol: measuring and modeling retarded leaching of mineral nitrogen. European Journal of Soil Science, v.53, n.2, p.185-194, 2002.

TERRY, R.E.; NELSON, D.W.; SOMMERS, L.E. Carbon cycling during sewage sludge decomposition in soils. Soil Science Society of America Journal, v.43, n.3, p.494-499, 1979a.

TERRY, R.E.; NELSON, D.W.; SOMMERS, L.E. Decomposition of anaerobically digested sewage sludge as affected by soil environmental conditions. Journal of Environmental Quality, v.8, n.3, p.342-347, 1979b.

TERRY, R.E.; NELSON, D.W.; SOMMERS, L.E. Nitrogen transformations in sewage sludge amended soils as affected by soil environmental factors. Soil Science Society of America Journal, v.45, n.3, p.506-513, 1981.

TESTER, C.F. Organic amended effects on physical and chemical properties o a sany soil. Soil Science Society of America Journal, v.54, n.3, p.827-831, 1990.

TISDALE, S.L.; NELSON, W.L.; BEATON, J.D. Soil fertility and fertilizers. New York: Macmillan; London: Collier Macmillan, 1985. 754p.

TRIGUEIRO, R.M. Uso de biossólidos como substrato para produção de mudas de pinus e eucalipto. Botucatu, 2002. 83p. Dissertação (Mestrado) - Faculdade de Ciências Agronômicas, Universidade Estadual Paulista “Julio de Mesquita Filho”.

TSUTIYA, M.T. Alternativas de disposição final de biossólidos. In: TSUTIYA, M.T.; COMPARINI, J.B.; SOBRINHO, P.A.; HESPANHOL, I.; CARVALHO, P.C.T; MELFI, A.J.; MELO, W.J.; MARQUES, M.O. Biossólidos na agricultura. São Paulo: SABESP: 2001. cap.5, p.133-180.

TSUTYA, M.T. Alternativas de disposição final de biossólidos gerados em estações de tratamento de esgotos. In: BETTIOL, W., CAMARGO, O. A. (Ed.). Impacto ambiental do uso agrícola do lodo de esgoto. Jaguariúna: EMBRAPA Meio Ambiente, 2000. cap.4, p. 69-105. 
UNITED NATION ENVIRONMENT PROGRAMME. GLOBAL ENVIRONMENT OUTLOOK. The state of the environment: past, present, future. http://www.unep.org/GEO/press.htm (03 mar. 2003).

VAN MIEGROET, H.; JOHNSON, D. W. Nitrate dynamics in forest soils. In: BURT, T. P.; HEATHWAITE, A. L.; TRUDGILL, S.T. (Ed.). Nitrate: process, patterns and management. Chichester: John Willey, 1993. cap.4, p.75-97.

VAZ, L.M.S.; GONÇALVES, J.L.M. Uso de biossólidos em povoamento de eucalipto: efeito em atributos químicos do solo, no crescimento e na absorção de nutrientes. Revista Brasileira de Ciência do Solo, v.26, n.3, p.747-758, 2002.

VETTERLEIN, D.; HUTTL, R.F. Can applied organic matter fulfil similar functions as soil organic matter? Risk-benefit analysis for organic matter application as a potential strategy for rehabilitation of disturbed ecosystems. Plant and Soil, v.213, n.1/2, p.1-10, 1999.

WANG, X.J.; SMETHURST, P.J.; HOLZ, G.K. Nitrogen fluxes in surface soils of 1-2year-old eucalypt plantation in Tasmania. Australian Journal of Soil Research, v.36, p.17-29, 1998.

WATER ENVIRONMENTAL FEDERATION. Residuals Management Committee. Biosolids and the 503 standards. Water Environment \& Technology, v.5, n.5, p.57-62, 1993.

WHYNOT, T.W.; WEETMAM, G.F. Repeated fertilization effects on nitrogen fluxes measured by sequential coring. Soil Science Society of America Journal, v.55, n.4, p.1101-1111, 1991.

YAN, F; SCHUBERT, S.; MENGEL, K. Effect of low root medium pH on net proton release, root respiration, and root growth of corn (Zea mays L.) and broad bean (Vicia faba L.). Plant Physiology, v.99, n.2, p.415-421, 1992.

YAN. F; SCHUBERT, S.; MENGEL, K. Soil pH increase due to biological descarboxylation of organic anions. Soil Biology and Biochemistry, v.28, n.4/5, p.617-624, 1996. 
ZABOWSKI, D.; HENRY, C.L. Soil and foliar nitrogen after fertiliser treatment of Pinus ponderosa. New Zealand Journal of Forestry Science, v.24, n.2/3, p.333343, 1994.

ZAMAN, M.; DI, H.J.; SAKAMOTO, K.; GOTO, S.; HAYASHI, H.; INUBUSHI, K. Effects of sewage sludge compost and chemical fertilizer application on microbial biomass and $\mathrm{N}$ mineralization rates. Soil Science and Plant Nutrition, v.48, n.2, p.195-201, 2002. 